CACILDA LOPES DOS SANTOS

\title{
NOVAS PERSPECTIVAS DO INSTRUMENTO DA DESAPROPRIAÇÃO: A INCORPORAÇÃO DE PRINCÍPIOS URBANÍSTICOS E AMBIENTAIS
}

Tese de doutorado apresentada à Faculdade de Arquitetura e Urbanismo da Universidade de São Paulo para obtenção do Título de Doutor em Arquitetura e Urbanismo.

São Paulo 
CACILDA LOPES DOS SANTOS

\section{NOVAS PERSPECTIVAS DO INSTRUMENTO DA DESAPROPRIAÇÃO: A INCORPORAÇÃO DE PRINCÍPIOS URBANÍSTICOS E AMBIENTAIS.}

Tese de doutorado apresentada à Faculdade de Arquitetura e Urbanismo da Universidade de São Paulo para obtenção do Título de Doutor em Arquitetura e Urbanismo.

Área de Concentração:

Tecnologia da Arquitetura

Orientador:

Prof. Dr. Emílio Haddad

São Paulo 
AUTORIZO A REPRODUÇÃO E DIVULGAÇÃO TOTAL OU PARCIAL DESTE TRABALHO, POR QUALQUER MEIO CONVENCIONAL OU ELETRÔNICO, PARA FINS DE ESTUDO E PESQUISA, DESDE QUE CITADA A FONTE.

ASSINATURA:

E-MAIL: CACILOPES@UOL.COM.BR

SANTOS, Cacilda Lopes dos

S237n Novas perspectivas do instrumento da desapropriação: a incorporação de princípios urbanísticos e ambientais / Cacilda Lopes dos Santos. - São Paulo, 2008.

231 p. : il.

Tese (Doutorado - Área de Concentração: Tecnologia da Arquitetura) - FAUSP.

Orientador: Emílio Haddad

1.Desapropriação (Aspectos urbanísticos) 2.Desapropriação (Aspectos ambientais) 3.Propriedade 4.Indenização I.Título 


\section{AGRADECIMENTOS}

A Deus, pela oportunidade de concluir um doutorado.

Ao Prof. Dr. Emílio Haddad, por sua dedicada orientação, contínuo incentivo e grande tolerância ao desenvolvimento deste trabalho.

Ao Prof. Nelson Saule Junior e Murillo Marx pelas contribuições quando da realização da banca de qualificação.

A todas as pessoas entrevistadas durante o desenvolvimento deste trabalho, em especial aos Juízes Estaduais Luiz Paulo Aliende, Rômolo Russo Junior e Venício Salles; aos Desembargadores Jô Tatisumi e Laerte Nordi; ao Juiz Federal Luciano Godoy; à Procuradora do Município de São Paulo Márcia Cristina Almada; ao Procurador do Estado de São Paulo Pedro Ubiratam Escorel de Azevedo, ao Promotor de Justiça Marcelo Daneluzzi, ao engenheiro florestal que atua junto ao Ministério Público Luiz César Ribas e ao engenheiro do IPT Rubens Dias Humphreys.

Às estagiárias Fernanda Massuci Posa Gonzalez e Natalia Fazano pelas pesquisas processuais realizadas.

Aos meus amigos, Dr. Emanuel Zinsly Sampaio Camargo e a Dra. Maria Luiza Dias de Moura, advogados da Caixa Econômica Federal, pela valiosa interlocução nos momentos de reflexão a respeito dos temas abordados nesta tese.

A minha querida amiga Rosane de Almeida Tierno, advogada com sólidos conhecimentos em direito urbanístico e em nosso vernáculo, a quem devo a revisão deste trabalho.

A concretização deste trabalho deve muito a eles; os erros evidentemente são todos meus.

Finalmente agradeço o afeto e apóio de Odália, Zezito, Claudinha e Paulo. 


\section{RESUMO}

SANTOS, Cacilda Lopes dos. Novas perspectivas do instrumento da desapropriação: a incorporação de princípios urbanísticos e ambientais p.231- Tese (doutorado) - Faculdade de Arquitetura e Urbanismo, Universidade de São Paulo. São Paulo, 2008.

O instituto da desapropriação é instrumento urbanístico muito utilizado no Brasil e em muitos outros países. No Brasil, a fundamentação legal da desapropriação decorre do Decreto-lei n ${ }^{\circ}$. 3365, de 21 de julho de 1941 e Lei $n^{\circ}$. 4132, de 10 de setembro de 1962 que tratam, respectivamente, de desapropriação por utilidade pública e por interesse social. É anterior, portanto, à Constituição Federal, que introduziu uma nova ordem urbanística em que se destacam o princípio da função social da propriedade e o planejamento urbano. A fim de regulamentar o capítulo da política urbana da Constituição Federal foi editado, em 2001, o Estatuto da Cidade que dispõe a desapropriação entre os instrumentos jurídicos da política urbana e a regulamenta como desapropriação-sanção. $\mathrm{O}$ trabalho estuda os principais aspectos da propriedade e do instrumento da desapropriação no direito brasileiro e na legislação estrangeira, analisando os modelos e métodos utilizados nos procedimentos de desapropriações por utilidade pública, interesse social, urbanística e ambiental. Também são estudados o conceito de justo preço para fins de indenização e os principais problemas de aplicação do instrumento; são apresentados estudos de casos de desapropriação. O trabalho termina por apontar sugestões que poderiam tornar o instrumento mais eficiente considerando o estágio atual do Estado Brasileiro e de suas Administrações Públicas.

Palavras chaves: Desapropriação, função social da propriedade, justo preço, avaliação, indenização 


\section{ABSTRACT}

SANTOS, Cacilda Lopes dos. New perspectives on the instrument of the expropriation --: the incorporation of planning and environmental principles - 2008. p .231- Doctorate Dissertation - Faculdade de Arquitetura e Urbanismo, Universidade de São Paulo. São Paulo, 2008.

Expropriation is planning tool widely used in Brazil in many other countries. In Brazil, legal fundament of expropriation is given by the Decreto-lei ${ }^{\circ} .3365$, of 21 of July of 1941 and Lei $\mathrm{n}^{\circ} .4132$, of 10 of September of 1962, that have dealt, respectively, with expropriation for public utility and for social interest. It is previous, therefore, to the Federal Constitution of 1988, that has introduced a new urban order in which the principle of the social function of the property and urban planning are emphasized. In order regulate the Federal Constitution's chapter on urban policy, it was edited, in 2001, the Estatuto da Cidade that includes expropriation among the legal instruments of the urban politics and regulates it as "dispossession-sanction". The Dissertation discusses main aspects of property and the instrument of the expropriation in the Brazilian law, and in foreign legislation, analyzing models and methods used in expropriation for public utility, social, planning and environment interests. Also the concept of just price of compensation and the main problems of application of the instrument are studied. Case studies are presented. The work finishes by suggesting measures for making the instrument most efficient considering the current situation of the Brazilian State and its Public Administrations

Keywords: expropriation; just price; social function of the property; evolution, compensation 


\section{ABREVIATURAS}

AC Acórdão de julgamento

CEPACS Certificados de potencial construtivo

CAJUFA Centro de Apoio aos Juízes da Fazenda Pública de São Paulo

CF Constituição Federal

IBAPE Instituto Brasileiro de Perícia e Engenharia

MC Medida Cautelar

PPPs Parcerias Público Privadas

Rel Juiz Relator

Resp Recurso Especial

Rextr Recurso Extraordinário

RJTESP Revista de Jurisprudência do Tribunal de Justiça do Estado de São Paulo

RT Revista dos Tribunais

STF Supremo Tribunal Federal

STJ Superior Tribunal de Justiça 


\section{SUMÁRIO}

\section{Capítulo 1}

INTRODUÇÃO

1.1 Justificativa

1.2 Objetivos

1.3 Metodologia e estrutura

\section{Capítulo 2}

\section{ASPECTOS GERAIS DO INSTRUMENTO DA DESAPROPRIAÇÃO}

2.1 Introdução: propriedade e função social

2.2 Aspectos gerais

2.3 Evolução histórica

2.4 Tratamento legal da desapropriação no Brasil

2.5 Fundamentos da desapropriação:

$\begin{array}{ll}\text { Princípio da supremacia do interesse público } & 28\end{array}$

2.6 Competências em matéria urbanística 30

2.7 O Estatuto da Cidade e a regulação da desapropriação sanção 32

2.8 Indenização da desapropriação-sanção 38

2.9 Destinação do bem expropriado 43

2.10 Conclusões 47

\section{Capítulo 3}

DESAPROPRIAÇÕES URBANÍSTICAS E AMBIENTAIS NO BRASIL

3.2 Diferenças entre desapropriação urbanística e desapropriação comum $\quad 55$

$\begin{array}{ll}3.3 \text { Procedimentos de avaliação } & 62\end{array}$

3.5 Conclusões: necessidade de legislação específica 71

\section{Capítulo 4}

JUSTO VALOR E SUA INDENIZAÇÃO

4.1 Conceito de justa indenização 75

4.2 Entendimento da doutrina e da jurisprudência sobre indenização 77

4.3 Correlação entre justo valor e princípios de direito urbanístico e ambiental 86

4.4 Função social da propriedade e justo valor 91

4.5 Recuperação das mais valias originadas por intervenção do Poder Público

e justo valor 94

$\begin{array}{ll}4.6 \text { Conclusão } & 98\end{array}$

\section{Capítulo 5}

PROBLEMAS DE APLICAÇÃO DA DESAPROPRIAÇÃO NO BRASIL

5.1 Desapropriação indireta e instrumentos afins

$5.2 \mathrm{O}$ problema da divisão federativa e seus reflexos nos julgamentos das desapropriações. Justiça Federal versus Justiça Estadual 112

5.3 As dificuldades técnicas enfrentadas pelo Judiciário no julgamento de processos de desapropriações

5.4 Excesso de "judicialização" e ausência de planejamento em tema de desapropriação.

5.5 A possibilidade de questionamento judicial do decreto de utilidade pública/interesse social 


\section{Capítulo 6}

A PRÁTICA DA INDENIZAÇÃO E ESTUDOS DE CASOS DE

ÁREAS DESAPROPRIADAS

6.1 Os métodos utilizados

$\begin{array}{ll}6.2 \text { A caixa preta: o laudo } & 125\end{array}$

$\begin{array}{ll}6.3 \text { Etapas da fixação do valor } & 127\end{array}$

$\begin{array}{ll}\text { 6.4 Estudos de casos } & 135\end{array}$

6.4.1 A experiência das indenizações ambientais no Estado de São Paulo 135

6.4.2 O caso do Parque Guapituba - Município de Mauá 137

6.4.3 A experiência das Varas especializadas na Comarca de São Paulo 141

6.4.3.1 Casos Pesquisados na Vara da Fazenda Pública do Estado de São Paulo 146

6.5. Conclusão 162

\section{Capítulo 7}

TEMAS E INSTRUMENTOS JURÍDICOS QUE MUDAM A

PERSPECTIVA DA DESAPROPRIAÇÃO.

$\begin{array}{ll}7.1 \text { A valoração econômica de recursos naturais } & 168\end{array}$

$\begin{array}{ll}\text { 7.2 As experiências da Colômbia e do Brasil } & 172\end{array}$

$\begin{array}{ll}7.3 \text { Instrumentos legais relacionados à desapropriação } & 176\end{array}$

$\begin{array}{ll}\text { 7.4 A parceria público-privada } & 177\end{array}$

7.5 A concessão urbanística e a desapropriação em favor de particular 182

$\begin{array}{ll}7.6 \text { Operações urbanas consorciadas } & 185\end{array}$

7.7 Os certificados de transferência de potencial construtivo - CEPAC'S 188

$\begin{array}{ll}7.8 \text { Direito de preempção } & 190\end{array}$

$\begin{array}{ll}7.9 \text { Outorga onerosa do direito de construir } & 191\end{array}$

$\begin{array}{ll}7.10 \text { Transferência do potencial de construir } & 192\end{array}$

$\begin{array}{ll}7.11 \text { Arbitragem no âmbito das desapropriações } & 194\end{array}$

\section{Capítulo 8}

$\begin{array}{lr}\text { CONCLUSÕES } & 198\end{array}$

$\begin{array}{ll}\text { Referências Bibliográficas } & 202\end{array}$

\section{Anexos}

Decreto-lei no 3.365 , de 21 de junho de 1941

Desapropriação por utilidade pública

Lei $\mathrm{n}^{\circ} .4 .132$, de 10 de setembro de 1962

Desapropriação por interesse social

Lei $n^{\circ} .8 .629$, de 25 de fevereiro de 1993

Desapropriação para reforma agrária

Lei $\mathrm{n}^{\circ}$. 10.257, de 10 de julho de 2001

Estatuto da Cidade 


\section{Capítulo 1}

\section{INTRODUÇÃO}

\subsection{Justificativa}

Esse trabalho nasce da experiência como advogada de Município, junto ao departamento de desapropriações, em um momento de ampla repercussão junto à sociedade sobre os elevados valores pagos a proprietários de imóveis a título de indenização. Foi essa experiência, no presente trabalho representada pelo caso da desapropriação do Parque Guapituba, no Município de Mauá, que nos despertou a consciência para os principais problemas da fixação da indenização em processo judicial.

No ano de 1993, o Município de Mauá deu início à desapropriação de uma área aproximada de 500.000 mil metros quadrados, com mata nativa, localizada na região central da cidade, para criação de um parque municipal, equipamento urbano do qual era carente.

Durante a tramitação desse procedimento judicial de desapropriação, evidenciouse a importância do laudo pericial para efeito de determinação da indenização, bem como a de se estabelecer uma comunicação eficiente entre peritos, juízes e advogados.

A singularidade desse caso, com duas perícias realizadas, inúmeras discussões com o judiciário e os peritos, demonstra a importância do tema da desapropriação, em especial do valor de indenização, sobretudo quando os laudos confeccionados no processo possuem resultados muito divergentes. 
A atuação como advogada do processo de desapropriação judicial do Parque Guapituba, a despeito de toda a batalha judicial travada, foi bem sucedida e suscitou o interesse nessa pesquisa, a fim de poder desvendar os principais problemas que envolvem os temas da indenização e do justo preço.

Com efeito, a desapropriação é instrumento largamente utilizado para aquisição de áreas ${ }^{1}$ pela Administração Pública a fim de atender o interesse público, seja ele de ordem urbanística, ambiental ou social. Assim, tal como outros instrumentos disciplinados pelo Estatuto da Cidade, traduz-se num importante instrumento de realização de política urbana.

Deste modo, diante das dificuldades enfrentadas pelas administrações públicas brasileiras, caracterizadas por um grande endividamento com as condenações advindas desses processos de desapropriação, entendemos de fundamental importância o estudo dos problemas que envolvem aplicação deste instrumento dentro do contexto da ordem urbanística inaugurada pela Constituição de 1988 e regulamentada pelo Estatuto da Cidade.

Os vários problemas enfrentados na aplicação do instrumento da desapropriação, também têm como causa a visão muito compartimentada dos profissionais do direito que atuam junto aos procedimentos, tais como juízes, advogados e, em alguns casos, promotores ${ }^{2}$, daí a importância de um estudo interdisciplinar, uma vez que o operador do direito não pode mais ter uma visão estreita da lei. Neste sentido destaca-se o estudo do instituto da desapropriação, cuja interdisciplinariedade é fator determinante para que sua aplicação ganhe eficiência.

\footnotetext{
${ }^{1}$ Observamos que o tema da pesquisa tem sido objeto de interesse por parte da FAUUSP, o que pode ser demonstrado pela pesquisa promovida pelo Laboratório de Habitação e Assentamentos Humanos - LAB-BAB: "Preço de desapropriação de terras: limites às políticas públicas nas áreas de habitação, meio ambiente e vias públicas em São Paulo" 2000.

2 Anotamos nossa participação em projeto pesquisa, desenvolvida pelo Prof. Dr. Emílio Haddad para o Lincoln Institute of Land Policy, cuja tema é Pesquisa sobre os novos procedimentos em processos judiciais de desapropriação do Poder Judiciário da Comarca de São Paulo. The Positioning of the Judiciary on Real Estate Valuation: the Case of Sao Paulo, Brazil, 2007.
} 


\subsection{Objetivos}

Através da análise de casos de desapropriação no Estado de São Paulo, compreendendo o período de 1995 até 2006, a tese tem por objetivo estudar a importância da inclusão de fundamentos urbanos e ambientais na fixação de uma indenização justa, como base para uma política de recuperação das mais valias urbanas e para a gestão ambiental da terra em projetos urbanos.

Destacamos que há poucos trabalhos acadêmicos que enfrentam o tema da avaliação nos processos de desapropriação e, a presente tese, que agrega conceitos de planejamento e legais, visa a colaborar para o desenvolvimento do tema no Brasil, estimulando que novos estudos e enfoques sejam produzidos. Além disso, atualizará a análise do instrumento da desapropriação, tomando por base a evolução das questões urbanas e ambientais brasileiras.

\subsection{Metodologia e estrutura}

A pesquisa investigará o modo de determinação do preço da terra em processos judiciais de desapropriação partindo de estudos de processos de especial relevância urbanística e ambiental para o Estado de São Paulo, como são os casos da Serra do Mar e o de Parques Públicos situados na Grande São Paulo, em especial o Parque Guapituba, no Município de Mauá, e processos atuais julgados pelas varas da Fazenda Pública da Comarca de São Paulo.

A investigação adotou como fundamentos teóricos os seguintes elementos:

a) A noção de justo valor de indenização. 
b) A recuperação para o Poder Público de mais valias fundiárias originadas por suas intervenções.

c) A aplicação do princípio da função social da propriedade na fixação dos valores de aquisição de terras

d) A noção de valor do meio ambiente.

Essas teorias possuem ampla literatura a fundamentá-las, que conjugadas aos estudos de casos, o trabalho foi assim dividido: iniciou-se com o estudo dos aspectos que envolvem o instrumento da desapropriação, na seqüência: como ocorre sua utilização para finalidades urbanísticas e ambientais. Após, analisamos os problemas que envolvem a noção de justo preço e, em capítulo a parte, os demais problemas relacionados à desapropriação. Em seguida analisamos a prática da indenização e descrevemos os casos estudados. O último capítulo relaciona temas e instrumentos urbanísticos que atribuem uma nova perspectiva ao instrumento.

Para a consecução dos objetivos acima referidos, foram necessárias as seguintes etapas:

1. Estudo da legislação urbana atual e sua relação com a legislação que rege o instituto da desapropriação, a fim de entender como o instrumento é utilizado no direito brasileiro, bem como esclarecer as relações que se estabelecem entre os principais atores durante o processo judicial de desapropriação.

2. Estudo de processos judiciais de desapropriação ambiental e urbanística relevantes no Estado de São Paulo e região metropolitana, sobretudo o estudo dos diversos laudos discrepantes confeccionados para fundamentar o processo judicial. 
3. Estudo da experiência adotada pelas Varas da Fazenda Pública na Justiça Estadual de São Paulo, Capital.

4. Análise de decisões judiciais junto aos tribunais superiores, ou seja, o estudo da jurisprudência.

5. Entrevistas com membros do Poder Judiciário: procuradores e peritos avaliadores que atuam em processos judiciais de desapropriação. 


\section{Capítulo 2}

\section{ASPECTOS GERAIS DO INSTRUMENTO DA DESAPROPRIAÇÃO}

A regulação da desapropriação nasce em momento imediatamente posterior à regulação da propriedade. Seus elementos atuais foram constituídos após a Revolução Francesa e exerceram influência na legislação brasileira. A fim de entendermos os modelos atuais de desapropriação estabelecidos pela legislação brasileira, neste capítulo faremos uma breve digressão histórica do instrumento.

\subsection{Introdução: propriedade e sua função social}

No Brasil a regulação do direito à propriedade imobiliária ocorreu com a edição da denominada Lei de Terras, Lei $\mathrm{n}^{\circ}$. 601, de 18 de setembro de 1850. A partir desta Lei, as terras brasileiras passaram a ser registradas em Cartório com base nos títulos de sesmarias ou de posse mansa e pacífica. Foi prevista também a aquisição de terras devolutas por contrato de compra e venda firmado com o Império.

Segundo Rolnik (1997, p.23):

“a promulgação da Lei de terras marca um corte fundamental na forma de apropriação da terra no Brasil, com grandes conseqüências para o desenvolvimento das cidades. A partir de sua promulgação, a única forma legal de posse da terra passou a ser a compra devidamente registrada. Foram duas as implicações imediatas dessa mudança: a absolutização da propriedade, ou seja, o reconhecimento do direito de acesso se desvincula da condição de efetiva ocupação, e sua monetarização, o que significa que a terra passou a adquirir plenamente o Estatuto da Cidade de mercadoria."

E complementa "Ao longo do século XIX, a terra, gradualmente, substitui o escravo na composição da riqueza". 
Ademais, o setor privado se ocupou lucrativamente destas mesmas concepções na valorização dos espaços da cidade que interessavam aos interesses especulativos, como indica (MARX, 1991) ao enfatizar que desde 1850, com a Lei de Terras, baseada no liberalismo, o conceito da terra foi universalmente transformado, conferindo-lhe o caráter de mercadoria e, incluída neste conceito, também estava a terra urbana.

Por conseqüência, o conceito tradicional de propriedade utilizado durante muitos anos pela legislação brasileira consistia em tratá-la como sendo um direito real amplo e importava nos poderes de usar, gozar, e dispor da coisa de forma absoluta, exclusiva e perpétua e de persegui-la de quem quer que injustamente a detivesse. Ainda, cujo desmembramento implicava a constituição de direitos reais parciais.

A propriedade era definida como relação de direito privado, mediante a qual uma coisa pertencente a uma pessoa estava sujeita totalmente à sua vontade em tudo que não fosse proibido pelo direito público e pela concorrência de direito alheio. Era, então, o poder geral e independente da pessoa sobre a coisa para fins de direito, reconhecido pelos limites estabelecidos pelo direito. Essa idéia sofreu alterações e hoje a propriedade deixa de ser o direito subjetivo do indivíduo e passa a ser a função social do detentor dos capitais mobiliários e imobiliários.

Assevera Salles ( 2006, p.77)

\footnotetext{
"Na Idade Média, o direito de propriedade era encarado, também, sob o aspecto de sua função social. Com efeito, deve a propriedade representar um elemento de ordem e a paz social, prestando-se à organização e ao rendimento da produção. (...). Por outro lado, no direito medieval, havida a terra como sinal de poder e riqueza, só a propriedade imóvel tinha valor, era a propriedade por excelência, sendo a propriedade móvel relegada a um plano secundário, (...)".
} 
Note-se que a "Declaração dos Direitos do Homem e do Cidadão", de 1789, proclamava ser a propriedade "direito inviolável e sagrado", mas o Código de Napoleão, de 1804, festejando valores individualistas, consagrou como princípio a legitimidade da limitação do Estado sobre a propriedade ao definir esse instituto como o direito de gozar e de dispor das coisas de modo absoluto, contando que isso não se tornasse uso proibido pelas leis e pelos regulamentos. Assim, foi-se condicionando cada vez mais o exercício do direito de propriedade ao bem-estar social, permanecendo o princípio e alargando o seu alcance. Hoje prevalece o princípio da função social da propriedade, que limita o uso e o gozo absoluto pelo dono da propriedade.

Atualmente, o direito de propriedade outrora absoluto, está sujeito a numerosas restrições fundamentadas no interesse público ou social, e também no próprio interesse privado, de sorte que o traço nitidamente individualista de que se revestia, deu lugar à concepção diversa, de conteúdo social própria do âmbito do direito público.

Apregoa Silva (1996, p. 749) que "a função social da propriedade diz respeito à estrutura dela mesma, e não a um mero sistema de sua limitação", conclui afirmando que este último diz respeito "ao exercício do direito, ao proprietário; aquela (a função social da propriedade), à estrutura do direito mesmo, à propriedade". Lembra ainda Silva (1996, p.749), que "bastava à disposição contida no inciso XXIII, do artigo 5. , da Carta Magna, para que toda a forma de propriedade fosse intrinsecamente permeada ao princípio constitucional da função social da propriedade".

Como bem menciona Oliveira (2000, p. 35):

\footnotetext{
"O bem-estar da sociedade, em especial do indivíduo como membro ativo e participante, passou a ser missão primordial do Poder Público, fazendo com que a propriedade perdesse seu marcante caráter de direito subjetivo individual para ser considerada sob o prisma de função social, bem da coletividade".
} 
Essa idéia foi inteiramente assimilada pelo atual Estatuto da Cidade ao estabelecer que o proprietário negligente com o bem que lhe pertence, abandonando-o, subutilizando-o, conservando-o improdutivo, não o explorando, explorando abaixo de suas reais possibilidades, dá ensejo à hipótese de intervenção estatal na propriedade, mediante a desapropriação, que retirando a propriedade do proprietário negligente, a transfere para quem possa dar-lhe a destinação social prevista, ou seja, "a Administração pelo Estado intervém no sentido de transferir a propriedade e a posse a quem melhor se utilize em benefício do bem comum ou em razão do interesse social". (FAGUNDES, 1994, p.54).

A sujeição da propriedade ao interesse público adentrou no ordenamento, brasileiro por meio da Carta de 1934 que, em seu art. 113, § 17, embora sem fazer expressa menção ao princípio da função social, garantia o direito de propriedade, destacando que o seu uso não poderia ser exercido em contraposição ao interesse social ou coletivo.

A Constituição de 1946, por sua vez, também se inspirou no princípio em comento quando da criação da até então inédita modalidade de desapropriação por interesse social, que conforme redação que lhe foi dada pela Emenda $n^{\circ} .10$, de 1962, passou a prever a possibilidade dessa forma expropriatória ${ }^{3}$ como sanção ao proprietário rural que não adequasse a utilização de seu imóvel ao bem-estar social. Em contrapartida, assegurava-lhe indenização a ser paga em títulos da dívida pública.

Destacamos que essa idéia também poderia ter sido aplicada para imóveis urbanos, conforme se pode depreender da leitura da Lei ${ }^{\circ}$. 4.132, de 10 de setembro de 1962 , que disciplinou a desapropriação para fins de interesse social. Neste sentido Dallari (1981, p. 97) ensina: "qualquer atividade econômica, agrícola, comercial ou industrial que não esteja

\footnotetext{
${ }^{3}$ Esclarecemos que nesta tese utilizamos as expressões “ desapropriação" e "expropriação" como sinônimas
} 
cumprindo sua função social por se constituir em fonte de desequilíbrio urbano pode ser objeto de desapropriação".

As desapropriações desta modalidade encontram-se insertas no artigo $2^{\circ}$. da Lei $n^{\circ}$ 4132, de 10 de setembro de 1962. Como exemplo dos bens que poderiam ser desapropriados com base no princípio da função social da propriedade, citamos o seu Inciso I: "o aproveitamento de todo bem improdutivo ou explorado sem correspondência com as necessidades de habitação, trabalho e consumo dos centros de população a que deve ou possa suprir por seu destino econômico".

No entanto, citada lei não guardava nenhuma correspondência com o planejamento da cidade, circunstância que contribuiu para sua pouca utilização pelos Municípios brasileiros. $^{4}$

A função social da propriedade, de forma geral, desatrelada do instituto da desapropriação, só foi mencionada expressamente pela Constituição de 1967, art. 157, III, arrolando-a como um dos princípios da ordem econômica e social.

No entanto, foi somente o constituinte de 1988 que tratou de definir o conteúdo da função social da propriedade. E o fez não só quanto à propriedade rural (art. 186), mas, também, quanto ao cumprimento da função social pela propriedade urbana (art. 182, §2 $2^{\circ}$, ao determinar que cada Município deve estabelecer a função social das propriedades situadas em seu território.

Historicamente, as discussões jurídicas relativas à questão urbana tiveram início após a Revolução Industrial. A elevação da concentração populacional deu origem a

\footnotetext{
${ }^{4}$ Sobre o nosso entendimento a respeito da utilização da Lei de desapropriação por interesse social em razão da nova disciplina para a política urbana, consoante art. 182 da Constituição Federal, ver item 4.3, do Capítulo 4 deste trabalho.
} 
problemas típicos de grandes cidades, como escassez de espaços habitáveis, precariedade do saneamento e do transporte e elevação dos índices de poluição. A necessidade de organizar o desenvolvimento e o crescimento urbano e de diminuir o déficit habitacional deu ensejo à criação de políticas públicas, realizadas por meio do planejamento urbanístico e de normas quanto ao uso e à ocupação do solo, direcionadas às áreas consideradas prioritárias e à solução dos problemas derivados da urbanização moderna.

Como parte da realização dessas políticas é atribuída aos proprietários de imóveis situados nessas áreas, certas obrigações passam a imprimir à propriedade urbana significação pública específica: não mais se admite o não uso do imóvel com fins meramente especulativos ou sua utilização para satisfação de interesses exclusivamente privados.

Trata-se da submissão da propriedade urbana a uma função social, como bem sumariado por Carceller Fernández (1997, p.38):

\footnotetext{
"Los proprietarios de toda clase de terrenos y construcciones deberán destinarlos a usos que no resulten incompatibles con el planeamiento urbanístico y mantenerlos en condiciones de seguridad, salubridad y ornato público. Quedarán sujetos igualmente al cumplimiento de las normas sobre protección del medio ambiente y de los patrimonios arquitectónicos y arqueológicos y sobre rehabilitación urbana."
}

Desta forma, a função social da propriedade urbana está vinculada ao conteúdo dessas políticas de planejamento e ordenação urbana, que são delimitadas e especificadas no denominado plano diretor do Município.

Não obstante o Município em Constituições anteriores, na qualidade de ente da Federação, já tivesse recebido algumas competências em temas urbanos, uma visão global da questão urbana só recebeu regramento constitucional por meio da Carta de 1988, que de forma inédita não só repartiu as competências legislativas e executivas em matéria urbanística, como também dedicou um capítulo específico à política urbana. 


\subsection{Aspectos gerais}

Com o advento da Constituição Federal e do Estatuto da Cidade, Lei n ${ }^{\circ}$ 10.257, de 10 de julho de 2001, que disciplinou muitos instrumentos urbanísticos, tem-se discutido sobre as várias possibilidades que a aplicação dos mesmos pode trazer para as cidades brasileiras.

Decerto que esses instrumentos têm o potencial de conferir outra dinâmica à vida urbana das cidades, entretanto o instrumento da desapropriação ainda exerce grande importância urbanística, não obstante a "crise" que vivencia, por força dos elevados valores que resultam dos processos judiciais a ela relativos. Este fator vem contribuindo em demasia para o endividamento das fazendas públicas, que se evidencia pelo grande número de precatórios $^{5}$ que aguardam pagamento por parte dos poderes públicos.

O foco do presente trabalho discute as avaliações confeccionadas nos processos judiciais, a fim de fornecer ao Poder Judiciário elementos para fixação do valor justo da indenização. Para isso, é de grande importância, inicialmente, traçar algumas características do instituto no direito brasileiro.

Não obstante a nova ordem urbanística instituída pelo Estatuto da Cidade, o instituto da desapropriação é regulado por legislação muito antiga: o Decreto-Lei n ${ }^{\circ}$. 3.365, de 21 de junho de 1941 e a Lei $\mathrm{n}^{\mathrm{o}}$. 4.132, de 10 de setembro de 1962, ambos anteriores à Constituição de 1988 e com pouquíssimas alterações desde suas respectivas edições.

\footnotetext{
${ }^{5}$ Precatório é ordem de pagamento expedida pelo Tribunal de Justiça competente dirigida ao poder público devedor, para que inclua o débito judicial do qual não cabe mais recurso no orçamento do exercício seguinte. Como o número de precatórios judiciais é expressivo, ele recebe um número de ordem para não ser preterido. No entanto, muitas vezes, por ausência de disponibilidade financeira, o precatório não pode ser incluído nos orçamentos imediatamente posteriores ao recebimento do ofício do Tribunal, o que faz com que o credor espere anos para receber o pagamento.
} 
No decorrer do presente trabalho, esse dado será tema recorrente, pois o modelo legal de desapropriação prevista no direito brasileiro não se refere expressamente às desapropriações urbanísticas e ambientais, nem tampouco aos critérios a serem observados na confecção dos laudos de avaliação. Paradoxalmente, o Poder Judiciário Paulista está abarrotado de processos que tratam especificamente sobre desapropriações urbanísticas e ambientais.

Nada mais árduo que o exame do instituto jurídico da desapropriação no âmbito do direito brasileiro e comparado. Quase todos os problemas levantados são munidos de contestações, embates discursivos e muita polêmica entre os aplicadores do Direito.

\subsection{Evolução histórica.}

A Revolução Francesa ao instaurar uma nova ordem política e social e proclamando o Princípio da Inviolabilidade do Direito de Propriedade, também deu origem ao fato jurídico da expropriação ${ }^{6}$ com os contornos que hoje são adotados na legislação de diversos países.

Como já mencionado, a Declaração dos Direitos do Homem e do Cidadão, que a Assembléia Nacional Constituinte proclamou em 20 de agosto de 1789, destacava com preponderância o direito inviolável e sagrado que caracterizava a propriedade. Os fatores basilares para a consumação da desapropriação, quais sejam: a necessidade pública e a prévia e justa indenização, foram incluídas no texto da Constituição de setembro de 1791, servindo de paradigma à legislação contemporânea sobre este instituto. Não era bastante que houvesse utilidade pública, era preciso que houvesse a incidência de necessidade pública. Em resumo, a

\footnotetext{
${ }^{6}$ Como já mencionado, adotamos como sinônimas as terminologias expropriação e desapropriação.
} 
grande contribuição da Revolução Francesa para a expropriação foi configurá-la como destacado instituto jurídico, estabelecendo os pilares para o seu exercício.

No Brasil, antes da primeira Constituição Federal, não existia qualquer referência legislativa em relação à desapropriação. Antes da Constituição Imperial, vigoravam as Ordenações do Reino, ou Ordenações Filipinas, publicadas por Felipe II, da Espanha, e Felipe I, de Portugal, no ano de 1603, nas quais o soberano gozava de plenos poderes (absolutos), já que era concedida a ele a faculdade de se apoderar dos bens de seus súditos (ZERBES, 2007).

A Constituição do Império de 1824 seguiu os mesmos princípios garantidores da propriedade, mesmo que excluindo do texto constitucional o caráter sagrado da propriedade. Duas fases distintas formavam o processo de desapropriação. A primeira, a avaliação da necessidade pública que se dava por pedido do Procurador-Geral da Fazenda ao Magistrado do domicílio do proprietário e com a audiência deste. A segunda fase consistia na verificação da utilidade ou necessidade pública, realizada pelo legislativo e, a última, consistia em efetuar os cálculos do ressarcimento pecuniário, cujo procedimento era dado por arbitramento. Os árbitros eram nomeados pelo Procurador da Fazenda Pública e pelo dono da propriedade, o que atualmente corresponderia aos assistentes técnicos das partes.

No ano de 1845, as situações de utilidade pública foram ampliadas após a entrada em vigor do Decreto $n^{\circ}$. 353, de 12 de julho, sendo feitas muitas inovações como, por exemplo, a instituição do júri no processo de expropriação (ZERBES, 2007).

Em 1855, o Governo, com o advento do Decreto no. 816, de 10 de julho, estabeleceu o processo para a expropriação de prédios e terrenos que fossem necessários para a construção das obras e demais serviços pertencentes à Estrada de Ferro Dom Pedro II e as outras estradas de ferro do Brasil, e regular as regras para a indenização dos proprietários. 
Cumpre referir que o dispositivo supra não revogou o Decreto $n^{\circ} .353 / 1845$, eis que dispunha especificamente sobre estradas de ferro.

Essas leis vigoraram até 1903, ano em que o Decreto nº 1.021, de 26 de agosto, disciplinou que a toda obra da União e do Distrito Federal, aplicar-se-ia o Decreto ${ }^{\circ} .816$ e autorizou o Poder Executivo a promover a consolidação da legislação expropriatória. O Decreto $\mathrm{n}^{\circ}$. 1.021 criou a figura da imissão de posse liminar, o direito de retrocessão, no caso de não ter sido realizada a obra, entre outras inovações jurídicas, porém, só tinha vigência para as obras da União e do Distrito Federal, logo, não era aplicável aos Estados e aos Municípios.

Na seqüência, houve a baixa do Regulamento aprovado pelo Decreto $n^{\circ}$. 4.956, em 9 de setembro de 1903, o qual consolidou a legislação existente e alterou o processo sobre desapropriações por utilidade ou necessidade pública. Aqueles casos de verificação de necessidade pública eram cabíveis ao Procurador da República perante o Juiz secional do domicílio do proprietário.

Até o ano de 1917 nenhuma modificação foi feita na legislação; todavia, o Código Civil que entrou em vigor neste ano veio dispor sobre expropriação por necessidade ou utilidade pública como forma de perda da propriedade.

Com a promulgação da Constituição Federal de 1934, houve inovações no tocante ao exercício do direito de propriedade. Este direito não era mais absoluto e a desapropriação só poderia ocorrer em razão de utilidade ou necessidade pública, e mediante prévio e justo pagamento de indenização.

Nova Carta Política foi promulgada com o golpe político de 1937. Alterações, de fato, quanto ao direito de propriedade, vieram somente em 1942, após a entrada em vigor da 
Lei Constitucional $\mathrm{n}^{\circ} .5$, de 10 de março, que modificou o texto do art. 122, acrescentando mais um caso expropriatório: a suspensão da garantia do direito de propriedade de súditos de Estado estrangeiro que por qualquer forma tivesse praticado atos de agressão de que resultasse prejuízo para os bens e direitos do Estado Brasileiro ou bens e direitos de pessoas físicas ou jurídicas brasileiras. Verdade seja dita, não se tratava propriamente de uma expropriação, e sim, de um "confisco" de propriedades de súditos estrangeiros, cujo país tivesse praticado qualquer tipo de agressão contra a Nação Brasileira.

O Decreto-Lei no ${ }^{\circ} .3 .365$, de 21 de julho de 1941, surgiu, deste modo, em meio à vigência da Magna Carta de 1937. Mesmo com algumas modificações que lhe têm sido introduzidas com o passar dos anos, é ainda hoje o estatuto legal que regula a intervenção do Estado na propriedade privada por meio da expropriação no Brasil.

\subsection{Tratamento legal da desapropriação no Brasil}

No Brasil, há um único tratamento legal para o procedimento de desapropriação, quer seja ela para a finalidade de utilidade pública, urbanística ou ambiental.

Destacamos que a desapropriação para reforma agrária, Lei Federal nº 8629, de 25 de fevereiro de 1993, por se referir à imóvel rural, tem procedimento específico estabelecido pela Lei Complementar $n^{\circ}$. 76, de 06 de junho de 1993, que não é objeto de nosso estudo, pois é espécie de desapropriação de utilização exclusiva da União Federal e, este trabalho se restringe às desapropriações em áreas urbanas.

Repise-se que a desapropriação, é a forma drástica de intervenção do Estado na propriedade privada. Constitui-se na transferência compulsória de um bem, da esfera patrimonial do particular, para o domínio estatal, o qual poderá, ainda, em casos excepcionais, 
atribuí-lo a outrem. De qualquer maneira, sempre será o expropriado ressarcido pela privação patrimonial sofrida, mediante pagamento de indenização.

Por ser medida extremamente invasiva, a desapropriação só poderá ser utilizada pelo Poder Público em casos previamente definidos pelo legislador, que no Brasil, enquadram-se nas hipóteses de necessidade ou utilidade pública e por zona, Decreto-Lei n . 3.365, de 21 de junho de 1941, e interesse social, Lei n. ${ }^{\circ} 4.132$, de 10 de setembro de 1962 , modelos estes de desapropriação que nesse trabalho chamaremos de desapropriação comum. ${ }^{7}$

Com o advento do Estatuto da Cidade surge a desapropriação-sanção, também denominada de desapropriação urbanística, ${ }^{8}$ ou seja, uma desapropriação com caráter de penalidade em virtude da inércia de proprietários darem função social à sua propriedade, conforme orientação vinculada no plano diretor.

Contudo, relativamente às desapropriações urbanísticas propriamente ditas e ambientais, não há uma legislação específica como existe em outros países. A desapropriação para urbanização, no Brasil, é disciplinada pelo art. $4^{\circ}$ do Decreto-Lei ${ }^{\circ}$. 3.365, de 21 de junho de 1941, tratada como modalidade de utilidade pública, nos seguintes termos:

“Art. 4ํㅜ A desapropriação poderá abranger a área contígua necessária ao desenvolvimento da obra a que se destina, e as zonas que se valorizarem extraordinariamente, em conseqüência da realização do serviço. Em qualquer caso, a

\footnotetext{
${ }^{7}$ Destacamos que o Código Civil Brasileiro de 2002 introduziu uma nova "modalidade" de desapropriação no direito brasileiro, denominada por alguns autores como "desapropriação judicial”. No caso, uma decisão judicial "decretaria" a desapropriação na hipótese prevista no art. 1228: "O proprietário tem a faculdade de usar, gozar e dispor da coisa, e o direito de reavê-la do poder de quem quer que injustamente a possua ou detenha..(...) $\S 4^{\circ} \mathrm{O}$ proprietário também pode ser privado da coisa se o imóvel reivindicado consistir em extensa área, na posse ininterrupta e de boa-fé, por mais de 5 (cinco) anos, de considerável número de pessoas, e estas nela houverem realizado, em conjunto ou separadamente, obras e serviços considerados pelo juiz de interesse social e econômico relevante $5^{\circ}$ No caso do parágrafo antecedente, o juiz fixará a justa indenização devida ao proprietário; pago o preço, valerá a sentença como título para o registro do imóvel em nome dos possuidores.

O delineamento do significado e alcance dos conceitos de "extensa área", "boa-fé", "considerável número de pessoas" e "interesse social e econômico relevante" são muito elásticos e, como o instrumento é recente em nossa legislação, ainda não há exemplos de sua aplicação.

${ }^{8}$ Previsão no art. $182, \S 4^{\circ}$, III da Constituição Federal, com regulamentação dada pelo art. $8^{\circ}$ da Lei $n^{\circ}$. 10.257, de 10 de julho de 2001, o Estatuto da Cidade da Cidade.
} 
declaração de utilidade pública deverá compreendê-las, mencionando-se quais as indispensáveis à continuação da obra e as que se destinam à revenda.”

Muito embora a legislação brasileira considere a hipótese de desapropriação para urbanização, deixou de estabelecer regramento essencial quanto aos aspectos de fundamental importância para a adequada aplicação do instrumento nos dias atuais, como, por exemplo, critérios de avaliação e de indenização, pontos nucleares debatidos na justiça brasileira.

Assim, no dizer de Mello (2003, p. 729):

\begin{abstract}
“À luz do Direito Positivo brasileiro, desapropriação se define como o procedimento através do qual o Poder Público, fundado em necessidade pública, utilidade pública ou interesse social, compulsoriamente despoja alguém de um bem certo, normalmente adquirindo-o para si, em caráter originário, mediante indenização prévia, justa e pagável em dinheiro, salvo no caso de certos imóveis urbanos ou rurais, em que, por estarem em desacordo com a função social legalmente caracterizada para eles, a indenização far-se-á em títulos da dívida pública, resgatáveis em parcelas anuais e sucessivas, preservado seu valor real."
\end{abstract}

Entretanto, no âmbito da intervenção urbanística, a desapropriação tem sido o principal instrumento utilizado pelo Poder Público local, muito embora a Estatuto da Cidade tenha regulado outros instrumentos que podem vir a ser eficazes nas intervenções promovidas pelo Poder Público em meio urbano, como adiante verificaremos.

A fórmula tradicionalmente conhecida pelos administradores brasileiros para realizar intervenções urbanísticas, mas pouco eficaz para recuperar as mais valias originadas pela realização de obras públicas, é a denominada desapropriação por zona, prevista no art. $4^{\circ}$. do Decreto-Lei n ${ }^{\circ}$ 3.365, de 21 de junho de 1941.

No direito brasileiro a produção e a sistematização legislativa em matéria urbanística são muito recentes, de modo que a desapropriação urbanística não apresenta caracteres distintivos em relação à desapropriação comum, o que seria extremamente aconselhável, tendo em vista o escopo específico de sua intervenção na organização do espaço urbano. 
O Estatuto da Cidade é, sem dúvida, um primeiro passo em direção a um regramento específico nesse sentido, mas é importante haver regramento que contemple não só os casos de desapropriações de imóveis que não cumpram a função social estabelecida no plano diretor, mas também os casos de outras desapropriações urbanísticas. Nesse sentido, também seria de grande utilidade uma legislação de caráter geral que também estabelecesse os casos de desapropriação que descumpre a função social da propriedade para os Municípios que não possuem plano diretor.

\subsection{Fundamentos da desapropriação: princípio da supremacia do interesse público}

O princípio da supremacia do interesse público sobre o interesse privado não se encontra expresso no ordenamento jurídico administrativo, porém há em inúmeros princípios manifestações concretas de sua incidência implícita.

Este princípio tem como cerne o poder-dever intrínseco ao Estado de impor a prevalência do interesse da coletividade, cominada com o automático sacrifício do interesse dos particulares, posto que em favor do Poder Público, posição esta juridicamente tangível ao predomínio do interesse dado à sua cura. Sempre que houver a necessidade de optar entre um interesse individual e um interesse público, prevalecerá o interesse público, eis que este atua em prol de um interesse maior, ou seja, o da coletividade.

A afirmação clássica é a de que a supremacia do interesse público é quase um requisito do Direito Público. Desta supremacia resultam algumas conseqüências, quais sejam: determinadas prerrogativas, tais como a presunção de veracidade e de validade dos seus atos, ou a auto-executoriedade dos mesmos, e restrições, como a obrigatoriedade das licitações, a exigência do concurso público para contratação de seus funcionários, além da superioridade 
da administração em relação aos particulares. Destarte, o Poder Público, enquanto encontrarse na execução da função administrativa, goza de superioridade em relação ao particular.

Depreende-se disso tudo que a supremacia do interesse coletivo sobre o individual constitui um dos fundamentos da intervenção do Estado na propriedade privada, eis que a Administração, no exercício desta prerrogativa que lhe é peculiar, tem a obrigação de fornecer ao cidadão condições de segurança e sobrevivência no seu cotidiano, mesmo que para isso tenha de intervir no bem imóvel de terceiros para gerar o bem-estar social. Este indicativo encontra guarida nas palavras de Mello (2003, p. 540) "a estabilidade da ordem social depende dessa posição privilegiada do Estado e dela depende a ordem e a tranqüilidade das pessoas".

Em síntese, toda a intervenção estatal na propriedade age com arrimo no interesse público, até porque, se esse agir se der em detrimento de um interesse particular, estará o Poder Público praticando atos que fogem a seus fins, como ostentador da supremacia do interesse coletivo.

Contudo, este postulado absoluto vem sofrendo várias críticas, tanto em nível nacional como internacional. Bucci (2002) desenvolveu importante estudo em que revela as contradições de conceitos ultrapassados relativamente às prerrogativas da Administração Pública e o atraso que causam ao desenvolvimento do país, citando como exemplo sua adoção em contratos administrativos e abuso dessas prerrogativas nos processos judiciais.

No caso dos processos judiciais de desapropriação, não obstante os problemas oriundos de avaliação, o abuso dessas prerrogativas é facilmente verificado na demora do Poder Público em efetuar os pagamentos fixados pelo Poder Judiciário, mesmo após o trânsito em julgado das decisões, situação que coloca o particular em situação de flagrante 
desvantagem. Nestes casos, a supremacia exercida pela Administração Pública se traduz em instrumento de afronta aos direitos dos cidadãos desapropriados.

A preocupação também é objeto de estudos de autores estrangeiros. Em estudo realizado por (AZUELA; HERRERA, 2007) destaca-se que países como França e Itália, cujas legislações são sempre citadas como modelo, a questão do poder discricionário do Estado, fundamentado em sua supremacia, tem sofrido alterações a fim de se limitar à atuação estatal em detrimento dos direitos do cidadão:

\footnotetext{
"At the same time, European countries like France and Italy, where land use policies and urban law had never been seen as being in conflict with the rule of law, have had to adapt their legislation in order to restrict the discretionary power exerted in expropriations, as a result of rulings from the European Court of Human Rights. “
}

O fundamento de validade das desapropriações reside na supremacia do Poder Público, este, indispensável para o atendimento ao interesse público da coletividade. Entretanto, anotamos que o problema enfrentado com a aplicação do instrumento da desapropriação no Brasil reside em grande parte na noção defasada de alguns postulados, notadamente pelo abuso da prerrogativa de pagamento pelo sistema de precatórios.

\subsection{Competências em matéria urbanística.}

Em relação ao direito urbanístico, o legislador constituinte de 1988 atribuiu competências às três instâncias da Federação. Em princípio, essa repartição de competências parece muito coerente porque a todos os entes da federação interessa obter a adequada ordenação do espaço urbano. No entanto, na prática, observa-se uma sobreposição de exercício de competências, tanto no que tange à produção legislativa dos entes federativos, como na gestão do solo. Destacam-se, nesse campo, as dificuldades encontradas nos licenciamentos ambientais e urbanísticos. 
Em matéria urbanística, a Constituição Federal de 1988 reservou à União Federal a competência para a edição de normas gerais (art. 24, I) e das "diretrizes para o desenvolvimento urbano" (art. 21, XX), resguardando aos Estados e ao Distrito Federal a competência suplementar, por se tratar de competência concorrente, nos termos do art. $24, \S \S$ $1^{\mathrm{o}}$ e $2^{\mathrm{o}}$.

Aos Municípios, por seu turno, por serem os entes políticos mais próximos dos problemas e das realidades dos cidadãos, a Constituição reservou a competência legislativa urbanística prevista no art. 30, inciso I. Assiste-lhes, também, o encargo de "promover, no que couber adequado ordenamento territorial, mediante planejamento e controle do uso, do parcelamento e da ocupação do solo urbano" (art. 30, VIII).

Com efeito, a política urbanística tem por escopo ordenar o meio urbano, propiciando condições adequadas de habitação, trabalho, recreação e circulação humana. Assim é que a Constituição Federal disciplina a política nacional de desenvolvimento urbano, cujo objetivo é a ordenação do pleno desenvolvimento das funções sociais da cidade e a garantia do bem-estar de seus habitantes (art. 182, caput), e requer a edição de plano diretor $\left(\operatorname{art.} 182, \S 1^{\circ}\right)$.

Para realização da política instituída pelos dispositivos citados, a Constituição conferiu ao Município instrumentos para compelir o proprietário do solo urbano não edificado, subutilizado ou não utilizado, a promover o seu adequado aproveitamento. Desse modo, de acordo com o art. 182, $\S 4^{\circ}$, poderá impor-lhe o parcelamento ou edificação compulsórios e, sucessivamente, o IPTU progressivo no tempo. Se, contudo, ainda assim persistir o descumprimento da função social atribuída ao imóvel, poderá determinar a respectiva desapropriação, cujo pagamento será realizado em "títulos da dívida pública de emissão previamente aprovada pelo senado Federal, com prazo de resgate de até dez anos, em 
parcelas anuais, iguais e sucessivas, assegurados o valor real da indenização e os juros legais" (art. 182, § $\left.4^{\mathrm{o}}, \mathrm{III}\right)$.

Da análise das prescrições constitucionais acerca da questão urbanística, uma primeira conclusão resta evidente: os dispositivos acima assinalados não são auto-executáveis, ou seja, carecem de lei federal, no exercício da competência definida no art. 24, I da Constituição Federal, não apenas para fixar as diretrizes gerais referidas no caput do art. 182, mas também para regulamentar a utilização dos instrumentos instituídos pelo $\S 4^{\circ}$ do mesmo artigo. Esta lacuna foi preenchida com a edição do Estatuto da Cidade, Lei n. ${ }^{\circ} 10.257$, de 10 de julho de 2001, cuja parte relacionada ao presente trabalho é tratada no item seguinte.

\subsection{O Estatuto da Cidade e a regulação da desapropriação-sanção}

Atendendo aos reclamos dos urbanistas, dos administradores municipais e dos movimentos sociais, após 12 anos de tramitação, foi editado o Estatuto da Cidade, a lei federal de diretrizes de política urbana exigida pelo art. 182 do Texto Constitucional para regulamentação e implantação de seus dispositivos, e cuja inspiração é atribuída ao direito urbanístico de países como Espanha, Portugal e Itália, os quais tinham acabado de promulgar legislação assemelhada. ${ }^{9}$

Trata-se, decerto, de diploma inovador, cujo objeto, conforme estatuído pelo $\S$ único, do art. $1^{\circ}$, constitui o estabelecimento de "normas de ordem pública e interesse social que regulam o uso da propriedade urbana em prol do bem coletivo, da segurança e do bemestar dos cidadãos, bem como do equilíbrio ambiental". Dispõe ainda, em seu art. $2^{\circ}$, acerca dos objetivos da política urbana no sentido de ordenação do desenvolvimento das funções sociais da cidade e da propriedade urbana, de acordo com as diretrizes que estabelece.

\footnotetext{
${ }^{9}$ Por exemplo, a Lei $n^{\circ}$. 6/1998 de regime do solo espanhola
} 
O Estatuto da Cidade "nasce em meio a grande polêmica, própria dos textos que introduzem limitações ao exercício de direitos individuais, ensejando questionamentos acerca da constitucionalidade de vários de seus dispositivos" (COSTA, 2001,p.81). Sem embargo, não se restringe a regulamentar os instrumentos instituídos pela Carta Magna como o parcelamento e edificação compulsórios, o IPTU progressivo e a desapropriação, dispõe também sobre institutos até então inéditos no direito urbanístico brasileiro, como os direitos de superfície (arts. 21 a 23) e de preempção (arts. 24 a 27), e a outorga onerosa do direito de construir (arts. 28 a 31).

É necessário destacar, que não obstante a Lei n ${ }^{\circ}$ 10.257, de 10 de julho de 2001 seja de suma importância para a implantação da política urbana, alguns de seus institutos, para serem plenamente aplicáveis, ainda necessitam de regulamentação, mediante a edição do respectivo plano diretor e, posteriormente, de leis específicas, ambos de competência do ente municipal.

Consoante referenciado, o Estatuto da Cidade tratou de regulamentar os instrumentos criados pela Constituição para adequação da propriedade urbana não edificada, subutilizada ou não utilizada, à função social fixada pelo plano diretor de cada Município, disciplinando o procedimento que pode culminar na desapropriação para fins urbanísticos, mas que na verdade é a desapropriação-sanção.

Contudo, antes de se utilizar a desapropriação-sanção o Estatuto da Cidade, consoante dispõe a Constituição Federal, determina em seu art. $5^{\circ}$ a imposição compulsória do parcelamento, da edificação ou da utilização do imóvel urbano, situado em área incluída no plano diretor que esteja em desacordo com função social ali determinada. 
Note-se, porém, que embora a Constituição refira-se, tão-somente, ao parcelamento e à edificação compulsórios, o Estatuto da Cidade agregou, outrossim, a utilização compulsória. Tal acréscimo não destoa do texto constitucional, pois a própria Constituição Federal determina que o uso do solo seja matéria a ser disciplinada pelos Municípios, assim, determinar sua efetiva utilização está dentro dos fins dessa determinação, o que possibilita tornar o comando constitucional concreto.

O Estatuto da Cidade conceituou unicamente o imóvel subutilizado, definindo-o no $\S 1^{\circ}$ do art. $5^{\circ}$, como aquele cujo aproveitamento seja inferior ao mínimo definido no plano diretor. Não seria realmente necessário caracterizar o imóvel não edificado ou o não utilizado, cujos conceitos decorrem da interpretação literal.

Quanto ao seu procedimento, determina, em linhas gerais, que o proprietário de imóvel em desconformidade com o plano diretor será notificado para cumprir sua obrigação, apresentando projeto nesse sentido em prazo não inferior a um ano, e, após aprovação do projeto, disporá de, no mínimo, dois anos para iniciar as obras. Acrescenta que a notificação deve ser averbada no cartório de registro de imóveis para fins de conhecimento de terceiros, bem como que a transmissão do imóvel por ato inter vivos ou causa mortis posterior à notificação transfere as obrigações, sem interrupção de quaisquer prazos.

Caso o proprietário mantenha-se inerte, mesmo após as condições e os prazos concedidos, assiste ao Poder Público Municipal a imposição de sanções administrativas, escalonadas e sucessivas, sendo a primeira delas a aplicação do IPTU progressivo no tempo. 
A progressividade do IPTU ${ }^{10}$, nesse caso, dar-se-á mediante a majoração anual de sua alíquota, cujo valor será fixado por lei municipal e não excederá a duas vezes o valor referente ao ano anterior, respeitada a alíquota máxima de $15 \%\left(\operatorname{art.~} 7^{\circ}, \S 1^{\circ}\right)$. Além disso, o art. $7^{\circ}$ do Estatuto da Cidade determina, ainda, que a progressividade será mantida por um período de cinco anos. No entanto, acrescenta que, se a obrigação de parcelar, edificar ou utilizar não for atendida no qüinquiênio legal, o Município manterá a cobrança da exação pela alíquota máxima, até que seja adimplida a obrigação $\left(\operatorname{art} .7^{\circ}, \S 2^{\circ}\right.$ ), podendo, se preferir, valerse da desapropriação do imóvel, nos termos do art. $8^{\circ}$, do mesmo diploma legal.

Com efeito, somente após esses dois estágios, quais sejam, notificação ao proprietário para parcelamento, edificação ou utilização compulsória, e, em caso de não atendimento, imposição de IPTU progressivo no tempo, de forma escalonada durante um período de cinco anos, é que se poderá utilizar a desapropriação. Consoante se depreende da análise dos preceitos normativos constantes do art. 182, § 4. ${ }^{\circ}$, III, da Constituição Federal, e do art. 8. $^{\circ}$, do Estatuto da Cidade, referida desapropriação é denominada pela doutrina como "desapropriação para fins de reforma urbana" e tem por objeto o solo urbano. No entanto, não é qualquer imóvel urbano que poderá ser objeto do procedimento expropriatório ali disciplinado. A esse respeito, oportuna a advertência de Nobre Junior (2002, p.83):

\footnotetext{
"Faz-se preciso que se trate de imóvel inserido em área delimitada no plano diretor do respectivo Município. Ao fim, terá que se referir a solo urbano que não esteja edificado, ou esteja subutilizado, ou não utilizado. Em suma, há que se cuidar de imóvel não adequadamente aproveitado".
}

\footnotetext{
10 Note-se que, conforme dispõe o art. 156, § $1^{\circ}$, I, da CF/88, o IPTU pode apresentar alíquotas progressivas também em razão do valor do imóvel, com o que não se confunde a progressividade prevista no art. 182, § $4^{\circ}$, II, do Texto Constitucional. Aquele preceito autoriza o aumento da alíquota em função do aumento da base de cálculo do imposto (progressividade fiscal), enquanto que este artigo em comento disciplina a progressividade em função do tempo, como sanção pelo descumprimento da função social da propriedade urbana (progressividade extrafiscal).
} 
Conforme visto em linhas anteriores, essa hipótese de desapropriação constitui uma sanção imposta ao proprietário, que titular de imóvel situado em área urbana a que o plano diretor atribui certa obrigação, quedou-se inerte. A infração à lei consiste no descumprimento de dever ou ônus urbanístico.

A conceituação do instituto em muito se assemelha à desapropriação tradicional ${ }^{11}$. No entanto, o traço distintivo gira em torno dos fins a que se destina. Com efeito, em matéria de Direito Urbanístico, a desapropriação tem por escopo a conformação da propriedade privada ao planejamento urbanístico, ora porque determinado bem imóvel encontra-se em área integrante de projeto de urbanificação, ora porque seu proprietário está descumprindo a função social que lhe é legalmente atribuída.

Como já dito em linhas anteriores, a desapropriação para conformação ao planejamento urbanístico é prevista no art. $4^{\circ}$ do Decreto-Lei $n^{\circ} .3 .365$, de 21 de junho de 1941, como espécie de desapropriação por utilidade pública, sem tratamento específico de procedimento e de avaliação.

Desse modo, a desapropriação urbanística foi tratada pela Constituição unicamente sob o aspecto do descumprimento da função social da propriedade urbana, art. $182 \S 4^{\circ}$, atribuindo-lhe caráter sancionatório que se verifica pelo pagamento da indenização não em dinheiro, mas em títulos da dívida pública.

Neste capítulo, trataremos apenas da desapropriação de feição sancionatória. Os demais aspectos da desapropriação urbanística necessária ao planejamento urbanístico serão tratados em capítulo a parte, tendo em vista ser de grande importância para o objeto do presente trabalho.

\footnotetext{
11 Ou seja, aquela disciplinada para fins de utilidade pública ou interesse social, respectivamente tratada pelo Decreto-Lei ${ }^{\circ}$. 3.365, de 21 de junho de 1941 e Lei no ${ }^{\circ}$ 4.132, de 10 de setembro de 1962.
} 
Ressalta-se, finalmente, que a criação da desapropriação-sanção pela Constituição Federal é um reflexo que, de fato, já é assente na disciplina da propriedade em geral, que esta não mais detém o caráter absoluto de outrora. Ao contrário, hoje lhe é atribuída uma função, uma finalidade, qual seja: a de produzir riquezas para o crescimento e o desenvolvimento da coletividade.

Assim também é o tratamento legislativo quanto à propriedade urbana: não pode ser utilizada de acordo com a vontade exclusiva do seu titular, e mais: não pode ser inutilizada ou mesmo manter-se inerte com objetivos egoísticos de mera especulação imobiliária. O imóvel urbano deve fazer parte de um projeto maior, adequar-se a interesses meta-individuais no sentido de auxiliar na expansão da urbanificação, visando, sempre, o bem-estar e o interesse coletivo.

Nesta esteira é que a desapropriação para fins de reforma urbana torna-se instrumento imprescindível do administrador municipal para, penalizando o proprietário negligente, atribuir ao bem o seu aproveitamento adequado. No entanto, conforme se demonstrará a seguir, a disciplina conferida ao instituto em exame pelo Estatuto da Cidade lhe impõe características particulares e requisitos específicos, cuja inobservância impossibilitará sua utilização e lhe esvaziará o conteúdo.

Em resumo, a edição da Lei ${ }^{\circ}$. 10.257, de 10 de julho de 2001, intitulada Estatuto da Cidade, era muito aguardada pelos estudiosos do Direito Urbanístico e pelos próprios planejadores urbanos, pois não só criou instrumentos inéditos ao ordenamento brasileiro, como também trouxe a regulamentação de diversos institutos constitucionais que careciam de disciplina legal para serem amplamente difundidos. Dentre esses últimos encontra-se a desapropriação sanção para fins urbanísticos, que foi disciplinada pelo art. $8^{\circ}$ do Estatuto da Cidade, cuja análise se segue. 


\subsection{Indenização da desapropriação-sanção}

É pressuposto de qualquer hipótese de desapropriação, seja ela urbanística ou tradicional, o ressarcimento do expropriado, mediante pagamento de indenização. Conforme ressaltado anteriormente, a regra geral, contida no art. 5. ${ }^{\circ}, \mathrm{XXIV}$, da Lei Maior, é de que essa desapropriação seja justa, prévia e paga em dinheiro.

Porém, quando se trata de desapropriação por descumprimento de função social, a chamada desapropriação-sanção, a indenização estará sujeita a peculiaridades, exatamente pelo caráter sancionatório ostentado. Assim é que alguns ordenamentos jurídicos, como o espanhol, optaram por conferir à indenização valor menor que o de mercado. Outros, como o português, no qual se espelhou o legislador pátrio, a sanção consiste no pagamento mediante títulos especiais da dívida pública.

No Brasil, a Constituição adotou a sistemática de pagamento integralmente realizado mediante títulos da dívida pública. Deste modo, acrescenta o $\S 11^{\circ}$, do art. $8 .^{\circ}$, do Estatuto da Cidade, que tais títulos deverão ser previamente aprovados pelo Senado Federal e serão resgatáveis no prazo máximo de 10 (dez) anos, por meio de parcelas anuais e sucessivas, sendo-lhe assegurado o valor real.

Ademais, relativamente aos títulos emitidos para ressarcimento da desapropriação, dispõe ainda o $\S 3 .^{\circ}$, do art. $8 .^{\circ}$, que não terão eles poder liberatório para pagamento de tributos, ou seja, sendo os títulos emitidos para pagamento parcelado de indenização, aqueles ainda não vencidos não poderão ser utilizados para pagamento de tributos em atraso

Por outro lado, o $\S 2 .^{\circ}$ do mesmo art. $8^{\circ}$, gerou certa controvérsia doutrinária, pois, ao invés de utilizar os termos "prévia e justa", consagrados para a desapropriação tradicional, referiu-se unicamente ao "valor real da indenização", o que levou alguns doutrinadores a 
supor que, para a desapropriação urbanística sancionatória, estariam afastados os requisitos de anterioridade e justiça da indenização.

Acerca da possibilidade de o pagamento da indenização não anteceder a perda da propriedade, a questão parece ser menos tormentosa: "na espécie em comento, não há garantia de que a indenização seja prévia. Poderá, portanto, o legislador estabelecer que a mutação dominial no registro imobiliário se dê antes de quitado o valor do ressarcimento devido ao proprietário" (NOBRE JUNIOR, 2002, p.85).

No que tange à justiça da indenização, durante certo tempo, havia doutrinadores que supunham estar afastada a exigência de indenização em valor justo por ter a Constituição, bem como o legislador de 2001, utilizado a expressão "valor real". Entretanto, também essa discussão resta esvaziada de fundamentos.

Em verdade, na atualidade, a maior parte dos autores filia-se no sentido inverso, "o desapropriado já é suficientemente sancionado pelo fato de não receber a indenização prévia e em dinheiro, mas sim em parcelas anuais, em até dez anos, em títulos que não se prestam sequer como meio de pagamento de tributos" (BEZNOS, 2003, p.132). Acrescente-se que da desapropriação para fins de reforma agrária, que tem a mesma natureza sancionatória, não foi excluída a indenização em valor justo, não havendo, portanto, razão jurídica para a diferenciação em idêntica situação de descumprimento da função social da propriedade (BEZNOS, 2003).

Daí decorre, portanto, que, na ponderação das interpretações a disputar o significado do que se deva depreender por "valor real", prepondera aquela que se incline pela justeza da indenização, até porque, em caso de suposta lacuna no texto do art. $182, \S 4^{\circ}$, III, da Constituição Federal, a franquia da justa reparação ao expropriado há de ser inferida como 
direito fundamental implícito (art. $5^{\circ}, \S 2^{\circ}, \mathrm{CF}$ ), resultante do regime e dos princípios inerentes ao estado Democrático de Direito (NOBRE JUNIOR, 2002).

De qualquer forma, ainda que não conste do texto legal expressa referência ao valor justo da indenização, somente aduzindo ao valor real, a doutrina unânime a entende como sinônimos, sendo certo que, mesmo em se tratando de desapropriação-sanção, a indenização há de ser justa e corresponder ao valor integral do bem, pois o caráter sancionatório advém da própria privação da propriedade, como também do pagamento mediante títulos da dívida pública.

Uma vez concluindo que o "valor real da indenização" afina-se com o conceito de "justa indenização", há argumentos que sustentam ser inconstitucional o dispositivo contido no art. $8 .^{\circ}, \S 2^{\circ}$, I, do Estatuto da Cidade, segundo o qual "o valor da indenização refletirá a base de cálculo do IPTU [...]". Com efeito, nem sempre o valor da base de cálculo do IPTU traduz, com precisão, o valor de mercado de um bem, não havendo como lhe atrelar a fixação da indenização, sob pena de não estar conferindo ao imóvel seu justo valor, quando o valor venal for diferente daquele apurado para fins de cobrança da exação referida.

O preceito em comento parece resultar de inspiração no modelo da Ley del Suelo espanhola, a qual, conforme consta de análise anterior, atrela o valor da indenização ao valor fiscal $^{12}$. No entanto, repita-se, naquele ordenamento jurídico a indenização não há de corresponder a valor justo, circunstância que não é aceita pelos autores brasileiros, mas que, a nosso ver, deverá ser objeto de maiores discussões, sobretudo salientando-se as causas desta

\footnotetext{
${ }^{12}$ No sistema espanhol o valor da indenização não é o valor de mercado. Consoante ensina García de ENTERRÍA, "la base de cálculo es, pues, siempre el valor fiscal [...], como para el valor urbanístico (aplicable al suelo urbanizable una vez urbanizado y adquirido, por lo tanto, po sus titulares el derecho al aprovechamiento urbanístico), que se fijará por aplicación al aprovechamiento adquirido del valor básico unitario de repercusión establecido por la Administración tributaria para cada polígono, corregido en función de la concreta situación de los terrenos dentro de éste (art. 53). (ENTERRÍA, Eduardo García; FERNÁNDEZ, Tomás-Ramón, op. cit. P. 350 .
} 
espécie de desapropriação, qual seja, a infração à lei por parte do proprietário. Entendemos que referida desapropriação, como tem caráter de penalidade, não pode ter sua interpretação ampliada a fim de prejudicar o proprietário, em nome dos princípios que fundamentam o Estado de Direito.

Assim, a norma do Estatuto da Cidade penaliza o proprietário ao determinar o pagamento do valor real da indenização em títulos da dívida pública resgatáveis em até dez anos, descontado do montante as mais valias oriundas de obras realizadas pelo Poder Público após a notificação determinada pelo $\S 2^{\circ}$ do art. $5^{\circ}$. As penalidades já estão contidas na norma, sendo indevida atribuição de outras penalidades ao proprietário por força de interpretação, como por exemplo, aquela que porventura considere que a indenização não necessita ser justa.

O dispositivo do inciso I, do parágrafo segundo, em sua parte final, estabelece, ainda, que será descontado do montante indenizatório, o valor incorporado ao bem em razão de obras realizadas pelo Poder Público na área onde o mesmo se localiza. Comentando o preceito, Beznos (2003, p.134), suscita sua impropriedade, afirmando:

\footnotetext{
"Com efeito, tal previsão nada mais configura que uma contribuição de melhoria; portanto, tributo que somente pode ser cobrado como tal mediante a edição de lei específica oriunda da pessoa política dele beneficiária, que obedeça a uma série de requisitos previstos nos arts. 81 e 82 do Código Tributário Nacional".
}

No entanto, o desconto constitui forma de o Poder Público ressarcir-se de dispêndios por ele realizados e geradores de valorização em imóvel, de que o proprietário não deu causa, aliás, que sequer cumpre os ônus que a ele a lei incumbiu. Portanto, adequado às diretrizes gerais de política urbana.

Em primeiro lugar, o proprietário está sofrendo sanção por não fazer sua propriedade cumprir a função social. Aliás, ele estará plenamente ciente disso, por força da 
notificação ${ }^{13}$. E vale sempre lembrar que todas essas sanções podem ser evitadas caso o proprietário cumpra sua obrigação no prazo assinalado.

Em segundo lugar, no mesmo período em que o Município será beneficiado com a cobrança de IPTU sobre base de cálculo valorizada, o proprietário poderá ser beneficiado em eventual alienação do imóvel valorizado (ALMEIDA, 2002).

Entendemos que o desconto das mais valias originadas após a notificação do proprietário determinada no plano diretor é perfeitamente legítima, posto que fundada nas diretrizes gerais do Estatuto da Cidade (art. $\left.2^{\circ}, \mathrm{XI}\right)$.

O inciso II do mesmo $\S 2^{\circ}$, do art. $8 .^{\circ}$, exclui, ainda, do quantum indenizatório, os lucros cessantes e os juros compensatórios. Acerca dos lucros cessantes, por certo que não há como serem eles incluídos, pois, se o proprietário está sendo penalizado exatamente por não estar conferindo ao seu imóvel o aproveitamento decorrente do cumprimento de sua função social, não há como se falar em lucros que poderiam ter sido obtidos.

\footnotetext{
13 Importante destacar que o instrumento ainda é pouco utilizado pelos Municípios brasileiros, pois prescinde da elaboração de um banco de dados bem eficiente pela Administração Pública Muncipal. Nesse sentido, ver estudo elaborado a partir da experiência do Município de Santo André: “ (...) Uma primeira questão se relaciona com a eficiência do instrumento ainda pouco experimentado para promover a utilização ou disponibilização dos vazios urbanos a curto e médio prazo. O marco inicial dos prazos estabelecidos no Estatuto da Cidade da Cidade para cumprimento da obrigação é a notificação do proprietário, com as formalidades descritas naquela lei federal. $\mathrm{O}$ primeiro deles é de um ano para apresentação de projeto, salvo se a legislação municipal determinar outro, mais dilatado, ou ainda se conceder efeito suspensivo aos questionamentos apostos pelo proprietário.
}

No entanto utilização destes vazios depende também de fatores que não estão na governabilidade dos atores locais. A produção de habitação social para população de menor renda, por exemplo, depende de financiamento altamente subsidiado e em larga escala e portanto se relaciona à implantação e sucesso do Sistema Nacional de Habitação. A dinâmica dos investimentos do setor industrial e correlatos (logística e demais prestação de serviços industriais) se relacionam também com as condicionantes macroeconômicas, assim como em cada cidade e região há especificidades também no que tange à dinâmica imobiliária". BRUNO FILHO, Fernando Guilherme; DENALDI, Rosana. Parcelamento, edificação e utilização compulsórios e a concretização da função social da propriedade: notas acerca de uma experiência. Revista Oculum Ensaios. Volume 06. Jul/dez de 2006, p. 35 a 47 - PUCCAMPINAS. 
Questão mais tormentosa é a referente à incidência dos juros compensatórios. Os juros compensatórios são devidos ao expropriado como compensação pela perda da posse. Têm, então, o objetivo de compensar a perda da renda que poderia ter auferido o proprietário e que não o fez em razão da privação ab initio da posse do bem.

Embora alguns autores entendam que a "imissão antecipada na posse, anterior à efetivação da desapropriação, que implique sua perda antecipada haverá de ser compensada pelo pagamento de juros compensatórios" (BEZNOS, 2003, p. 135), suscitando a inconstitucionalidade do dispositivo referido, parece-nos mais acertada a posição daqueles que entendem sua exclusão condizente com o regime da desapropriação-sanção. De fato, se o imóvel não estava sendo utilizado ou o uso que lhe era atribuído contrariava o plano diretor, não há como suscitar a existência de renda a ser compensada.

Assim, considerando-se que na expropriação para reforma urbana, a despeito de sua indenização encontrar-se submetida ao imperativo de justeza, não se impõe seja prévia, razão pela qual o seu não pagamento integral, quando da imissão na posse, não enseja compensação em prol do proprietário (NOBRE JUNIOR, 2002). Somente serão devidos ao expropriado os juros legais de $6 \%$ ao ano para atualização do valor dos títulos, e os juros moratórios, também de $6 \%$ ao ano, nos termos da Súmula ${ }^{14} \mathrm{n}^{\mathrm{o}} .70$ do STJ e incidentes, desde o trânsito em julgado, sobre a diferença obtida entre o valor da indenização e aquele ofertado.

\subsection{Destinação do bem expropriado.}

A questão referente à destinação deferida ao bem após a efetivação da retirada compulsória do imóvel do patrimônio do ex-proprietário é disciplinada pelo Estatuto da Cidade nos $\S \S 4 .^{\circ}$ a $6 .^{\circ}$, do art. $8 .^{\circ}$. Nessa matéria transparece uma das várias particularidades

\footnotetext{
${ }^{14}$ Súmula é entendimento consolidado de um tribunal superior, no caso, do Superior Tribunal de Justiça.
} 
da desapropriação para reforma urbana em relação à desapropriação tradicional. É que nestas, em regra, o bem passa a integrar o patrimônio do ente expropriante, enquanto que naquelas, embora o imóvel possa permanecer em poder do Município que o utilizará de acordo com sua função social, a regra geral é que haja uma transferência a terceiros, aos quais será atribuída a obrigação urbanística.

Com efeito, o $§ 4 .^{\circ}$ do dispositivo mencionado determina que o Município terá o prazo de 5 (cinco) anos para proceder ao adequado aproveitamento do imóvel, prazo a ser contado a partir de sua incorporação ao patrimônio público. E o $§ 5^{\circ}$, por seu turno, dispondo acerca das formas de aproveitamento do bem, faculta ao ente municipal dar-lhe a destinação prevista em lei, diretamente, ou por meio de alienação ou concessão a terceiros, obedecendose, nesse caso, ao respectivo procedimento licitatório.

A análise destes dispositivos nos permite inferir que, após a efetivação da desapropriação, o Município tem um prazo para dar ao bem a destinação que lhe impõe o plano diretor e da qual o ex-proprietário estava remisso, ou seja, para efetuar o parcelamento, a edificação ou a utilização compulsórios. Poderá ainda o Poder Público optar por transferi-lo a terceiros. De qualquer sorte, não efetuando o adequado aproveitamento dentro do prazo estipulado, o próprio Estatuto da Cidade impõe ao administrador municipal as penas da improbidade administrativa, conforme preceituado no art. 52, II.

O preceito do referido $\S 5^{\circ}$ é, sem dúvida, importante instrumento para a moralidade do procedimento expropriatório e para o desenvolvimento da ordenação urbana, pois fixa prazo ao Município para realizar o aproveitamento, cuja omissão por parte do expropriado, deu ensejo à desapropriação. Exaltando sua importância, Fernando Dias Menezes de Almeida afirma que "seria inadmissível que o imóvel fosse retirado forçosamente 
do proprietário, em virtude do descumprimento da função social da propriedade, e que tal função social continuasse não sendo atendida quando o imóvel está sob o domínio municipal".

Por seu turno, adquirindo o imóvel por alienação ou concessão, o beneficiário passará a ser o responsável pelo cumprimento daquelas obrigações impostas ao bem no plano diretor e constantes do art. $5^{\circ}$ do Estatuto da Cidade.

Não fixa a lei, como fez em relação ao aproveitamento direto pelo Município, prazo para o cumprimento das obrigações que lhe assistem. Nesse aspecto, tem-se entendido que caberá ao Poder Público estipular um prazo no próprio edital licitatório e no contrato aquisitivo ou de concessão, que constitua verdadeira condição resolutiva. Desta forma, não cumprido o prazo, o bem retornaria imediatamente ao Município, sem necessidade de obediência dos prazos dos arts. $5^{\circ}$. e $6^{\circ}$. Não constando, porém, do ato tal condição, não restará alternativa ao Poder Municipal senão aguardar o decurso de um ano para apresentação de projeto, outro, para início das obras e, posteriormente, a aplicação por cinco anos do IPTU progressivo.

Por fim, ainda no que se refere à destinação do bem expropriado, importante discussão doutrinária tem sido travada quanto à aplicabilidade do instituto da retrocessão ${ }^{15}$ nesses casos de desapropriação para reforma urbana. No caso de desapropriação para reforma urbana, poderíamos vislumbrar hipótese de retrocessão para o caso de o Município, assumindo a obrigação de proceder diretamente ao aproveitamento do imóvel expropriado, não a cumpra dentro do prazo fixado pelo art. $8^{\circ}$., $\S 4^{\circ}$. do Estatuto da Cidade. Seria então o caso de conferir ao ex-proprietário o direito de preferência para aquisição de tal bem, pois, consoante ensina Mello (2003, p. 760):

\footnotetext{
${ }^{15}$ Retrocessão, na desapropriação comum, é o direito de preferência do ex-proprietário de reaver o bem que não cumpriu a finalidade prevista no decreto de desapropriação.
} 
"Ainda que se trate de desapropriação-sanção, não há porque se concluir de modo diverso: se tanto o antigo proprietário (expropriado) quanto o Poder Público expropriante descumprem a obrigação, é preferível que o imóvel retorne ao expropriado, em respeito ao direito constitucional de propriedade."

Acerca da retrocessão na desapropriação, duas questões devem ainda ser discutidas. A primeira é levantada por Nobre Junior (2002, p.88) e diz respeito à possibilidade de exercer o ex-proprietário a retrocessão nos casos em que o Município, ao invés de cumprir diretamente as obrigações decorrentes da função social, atribui tal encargo ao terceiro, que se mantém inerte. Segundo aquele professor, a inadmissão da retrocessão nesses casos poderia configurar desvio de finalidade. São suas as palavras:

\footnotetext{
"No particular da transferência do imóvel a terceiro, poder-se-á, caso o Município não atue com o cuidado necessário, inerente à fiscalização do adequado aproveitamento do bem, restar caracterizado, no mundo fático, desvio de finalidade, em virtude da indevida permanência do bem com aquele. É que se terá, sem causa jurídica, expropriação em benefício de interesse privado [...].
}

Com efeito, a retrocessão nesse caso também se impõe em vista da moralidade administrativa e do respeito à proteção constitucional da propriedade privada. No entanto, somente mediante análise do caso concreto, será adequado falar de sua real utilidade, não obstante, repita-se, seja a providência mais justa.

Uma segunda questão cuja discussão ainda não foi esgotada, refere-se à hipótese de o Poder Público Municipal, expropriando um imóvel por descumprimento da obrigação de adequação à função social imposta no plano diretor, ao final do prazo de cinco anos (art. $8^{\circ}$., $\S$ $4^{\circ}$. do Estatuto da Cidade), não lhe dê a destinação determinada pelo planejamento urbano, mas, confere-lhe destinação também de interesse social ou utilidade pública (como nos demais casos de desapropriação urbanística contidos no Decreto-Lei nº. 3.365, de 21 de julho de 1941 e na Lei $\mathrm{n}^{\mathrm{o}}$. 4.132, de 10 de setembro de 1962). Entendemos que, também nesse caso, teria o expropriado direito de retrocessão. 
Com relação à desapropriação tradicional, a doutrina nacional e estrangeira costuma entender que, sendo conferido ao bem expropriado destino que atenda ao interesse público, ainda que diverso daquele para o qual o imóvel foi expropriado, não há direito de retrocessão. No entanto, em se tratando de desapropriação para reforma urbana essa orientação merece ser vista com certa reserva, pois, em outras modalidades de desapropriação urbanística, o pagamento da indenização é efetuado em dinheiro e não em títulos da dívida pública e uma alteração de destinação como a aqui aventada, pode estar encobrindo uma tentativa do Poder Público Municipal de eximir-se do pagamento em dinheiro e protelar o ressarcimento do expropriado, mediante emissão de títulos públicos.

Conforme ressaltado, a desapropriação urbanística ainda não possui um regramento específico como em outros países. Desse modo, somente dispomos do art. $8^{\circ}$. do Estatuto da Cidade, o qual, no entanto, ainda carece de maior regulamentação. Falta, por exemplo, norma disciplinando o procedimento judicial a ser adotado pelo ente municipal para efetivação da expropriação em caso de discordância do expropriado com o valor ofertado.

Diante da lacuna quanto ao procedimento a ser adotado na desapropriação sanção, o procedimento deverá ser o da Lei Geral de Desapropriações, o Decreto-Lei ${ }^{o}$. 3.365, de 21 de julho de 1941.

\subsection{Conclusões}

Dentre os meios de que dispõe hoje o Poder Público para concretização de sua política urbana, o procedimento expropriatório é o mais drástico, porquanto impõe ao particular a efetiva perda de seu bem. Porém, como a experiência na utilização de instrumentos urbanísticos mais inovadores e às vezes usados de forma combinada com o 
instrumento da desapropriação, foi utilizado por poucas cidades brasileiras, ${ }^{16}$ como Porto Alegre, São Paulo e Belo Horizonte, a desapropriação ainda é o instrumento mais utilizado para regularização de assentamentos populacionais e o combate à acumulação de bens com fins meramente especulativos, além das hipóteses de simples ordenação urbana.

Mesmo em países onde a política urbana é bastante desenvolvida, como na Espanha, o instituto da desapropriação tem importância crucial para a conformação da propriedade privada ao planejamento urbano.

No entanto, não obstante os avanços efetuados pelo Estatuto da Cidade, o regime da desapropriação para reforma urbanística existente se restringe basicamente aos casos concretos de descumprimento da função social da propriedade urbana.

Um primeiro entrave a sua utilização consubstancia-se na necessidade de prévia produção legislativa e de adoção de procedimento preliminar. De fato, verifica-se que precede a utilização da desapropriação em comento, a edição de plano diretor pelo Município, e, após, lei específica determinando o parcelamento, a edificação ou a utilização compulsória. Deverá, então, notificar o proprietário para apresentar projeto em até um ano e, depois, aguardar outros dois anos para o início das obras. Desatendida a obrigação dentro desses prazos, deverá impor a cobrança do IPTU progressivo no tempo por, no mínimo, cinco anos. Só então, restando ainda inerte o proprietário, poderá o ente municipal efetuar a desapropriação do bem.

Para Di Pietro (2003, p.65), "sem considerar os prazos para aprovação do plano diretor e da lei específica, os demais prazos previstos no Estatuto da Cidade estão a indicar

\footnotetext{
16 Neste sentido conferir FURTADO, F.; REZENDE, V. L. F. M.; OLIVEIRA, M. T. C.; YORGENSEN, P.; BACELLAR, I. . Outorga Onerosa do Direito de Construir: panorama e avaliação de experiências municipais. In: XII Encontro Nacional da ANPUR, 2007, Belém. Integração sul-americana, fronteiras e desenvolvimento urbano e regional. Belém : Anpur - UFPA, 2007. v. 1
} 
que o decreto de desapropriação não poderá ser expedido antes do transcurso de aproximadamente oito anos".

Outro obstáculo à sua aplicação reside no fato de que o Constituinte vinculou a emissão de títulos da dívida pública municipal à prévia autorização do Senado Federal e este, por sua vez, editou a Resolução n $^{\circ} .78$, de 01 de julho de 1998, que vedou aos Municípios a emissão de títulos da dívida pública, salvo para financiamento de obrigações principais, até dezembro de 2010. Assim, os Municípios estão impossibilitados de emitir títulos para a finalidade da desapropriação por pelo menos sete anos

De tudo que foi demonstrado e comentado neste capítulo, verifica-se que por se tratar de instituto "jovem" no ordenamento jurídico brasileiro, se faz necessário o monitoramento das políticas de planejamento e gestão do solo urbano pelos Municípios, a fim de se verificar a sua efetiva aplicabilidade, como parte da realização do planejamento urbano instituído pelo plano diretor. Podemos assim inferir, que somente após o transcurso de aproximadamente dez anos poderemos nos deparar com algum caso de desapropriação por descumprimento da função social da propriedade privada.

Além disso, o Estatuto da Cidade deixou de disciplinar os demais casos de desapropriação para ordenação urbanística, não estabelecendo quaisquer critérios para avaliação e justo valor, a exemplo da experiência estrangeira.

Muito embora o Estatuto da Cidade discipline instrumentos de gestão urbana de modo a não incentivar o uso excessivo da desapropriação, seria conveniente traçar regramentos de caráter urbanístico também para a desapropriação por utilidade pública, que considerassem no cálculo da indenização aspectos relativos ao descumprimento da função social da propriedade, hoje só considerado na desapropriação-sanção, e também um melhor 
tratamento para recuperação das mais valias, aspecto tratado de modo muito superficial no Decreto-Lei n ${ }^{\circ} .3 .365$, de 21 de junho de 1941. 


\section{Capítulo 3}

\section{DESAPROPRIAÇÕES URBANÍSTICAS E AMBIENTAIS NO BRASIL}

Para iniciarmos a compreensão dos caminhos que levam à fixação da indenização no processo judicial de desapropriação, este capítulo analisa a lei desapropriação vigente, modelo para outras espécies de desapropriação, como é o caso das desapropriações para fins urbanísticos e ambientais, inclusive para aplicação da desapropriação para reforma urbana, prevista no Estatuto da Cidade.

\subsection{O modelo utilizado}

A Constituição Federal prevê a desapropriação em sua abrangência e limitações, contudo pautada sempre no interesse coletivo. Dessa forma, o texto constitucional propicia ao Estado, para a realização e cumprimento de seu compromisso de promoção dos interesses da coletividade, instrumentos como a desapropriação. Em contraposição, este instituto acompanha normas condicionadoras para sua realização, visando evitar qualquer espécie de abuso por parte do Poder Público.

A primeira condicionante encontra-se no artigo $5^{\circ}$., inciso XXIV da Constituição Federal de 1988 que preceitua: “a lei estabelecerá o procedimento para desapropriação por necessidade ou utilidade pública, ou por interesse social, mediante justa e prévia indenização em dinheiro, ressalvados os casos previstos nesta Constituição".

Neste sentido Fagundes (1949, p. 4):

\footnotetext{
"A necessidade pública aparece quando a Administração se encontra diante de um problema inadiável e premente, isto é, que não pode ser removido nem procrastinando e para cuja solução é indispensável incorporar no domínio do Estado
} 
o bem particular. A utilidade pública aparece quando a utilização da propriedade privada é conveniente e vantajosa ao interesse coletivo, mas não constitui imperativo irremovível. Haverá motivo de interesse social quando a expropriação se destine a solucionar os chamados problemas sociais, isto é, aqueles diretamente atinentes às classes pobres, aos trabalhadores e à massa do povo em geral pela melhoria nas condições de vida, pela mais eqüitativa distribuição da riqueza, enfim, pela atenuação das desigualdades sociais".

Para o autor, apenas a presença do termo utilidade pública já é suficientemente abrangente para impor as restrições necessárias.

A segunda condição exigida para a desapropriação é a prévia e justa indenização. Tal indenização deverá ser efetuada em dinheiro, podendo, excepcionalmente, ser realizada de outra forma mediante previsões legais.

Salienta Madeira (1998, p. 251) que devido ao fato da desapropriação ter como fundamento a persecução do bem comum, deve-se zelar pelos possíveis prejuízos do expropriado. Ainda, que há de ser preservado o patrimônio do particular; resguardando-o contra eventuais perdas, já que a desapropriação não tem caráter confiscatório.

E como o objeto da desapropriação terá a finalidade de atender às necessidades e interesses da coletividade, nada mais justo que tal ônus recaia sobre a própria coletividade, e não sobre o particular detentor do domínio em questão. Portanto, a indenização será advinda do sistema fiscal mantido pela coletividade.

A indenização deve ser anterior à imissão na posse, para evitar arbitrariedades por parte da Administração Pública; assim como deve ser justa, de modo que não haja prejuízo ao particular e enriquecimento ao Estado ou vice-versa.

A desapropriação pode ser classificada como ordinária ou extraordinária (DALLARI, 1981). A desapropriação ordinária pode ser ainda subdividida em desapropriação por utilidade pública, desapropriação por zona e a desapropriação por interesse social. Esta 
divisão não se encontra no texto constitucional, mas sim na legislação ordinária competente para a regulamentação do instituto (art. $4^{\circ}$. do Decreto-Lei $n^{\circ}$. 3.365, de 21 de julho de 1941; e art. $2^{\circ}$. da Lei $\mathrm{n}^{\circ} .4 .132$, de 10 de setembro de 1962).

Vale ressalvar a modalidade de desapropriação por zona que se encontra preceituada no artigo $4^{\circ}$. do Decreto-Lei $n^{\circ} .3 .365$, de 21 de julho de 1941:

"A desapropriação poderá abranger a área contígua necessária ao desenvolvimento
da obra a que se destina, e as zonas que se valorizem extraordinariamente, em
consequiência da realização do serviço. Em qualquer caso, a declaração de utilidade
pública deverá compreendê-las, mencionando-se quais as indispensáveis à
construção da obra e as que se destinam à revenda".

Nesses casos, a desapropriação se estende às áreas maiores que a necessária para a realização da obra, seja em função de futuras ampliações ou de um aumento previsível no valor dos imóveis adjacentes.

Nos casos de futuras ampliações da obra, deverá ser realizada a previsão no próprio projeto da obra envolvendo aquela remanescente. Se posteriormente aquela área não for devidamente utilizada poderá ser objeto de retrocessão. A ausência de disposição expressa sobre o prazo em que deve ser utilizado o bem desapropriado para o fim em função do qual se desapropriou não corresponde a uma autorização para que o Poder Público utilize ou não o bem; escolha com total liberdade o momento da utilização ou decida sem qualquer limitação a respeito da extensão da área desapropriada (DALLARI, 1981).

Já nos casos de reserva da área para posterior aumento de imóveis adjacentes, a manutenção dessa área se dá em função da mais-valia que se cria em função da obra realizada. Essa revenda das áreas desapropriadas posteriormente valorizadas é legalmente autorizada baseada numa espécie de custeio a obra geradora da mais-valia. Normalmente, o custo das obras é dado através da contribuição de todos, contudo, nesses casos é autorizada a 
desapropriação de áreas maiores do que a obra em questão, para que a revenda posterior arque com as despesas.

Contudo, a doutrina encontra-se dividida quanto à espécie de desapropriação, uma vez que a forma de custear as obras públicas é realizada através das contribuições de melhoria, e não por meio de desapropriações. Neste sentido, Dallari (1981, p. 93) afirma:

\footnotetext{
"por ser contribuição de melhoria apenas um instituto afim e alternativo à desapropriação por zona, é certo que a existência daquela não gera a inconstitucionalidade desta. Além disso, é perfeitamente legitima a absorção de mais-valia pelo Poder Público quando decorrente de obra por ele realizada com base no principio que veda o enriquecimento sem causa e no antiquíssimo princípio da equidade (suum cuique tribuere)".
}

A desapropriação extraordinária para Pinheiro (2004, p.73) "tem como fundamento o descumprimento função social da propriedade e compreende duas subespécies". São elas subdivididas em desapropriação por interesse social para fins de reforma agrária, e a desapropriação para fins de reforma urbana.

A primeira, para fins de reforma agrária, é utilizada pela Constituição Federal de 1988 como uma espécie de sanção ao proprietário que não realiza os devidos fins sociais atribuídos a sua propriedade. O cumprimento da função social em questão poderá ser avaliado através da Lei $n^{\circ}$. 8.629, de 25 de fevereiro de 1993. Essa espécie de desapropriação recai sobre imóveis rurais e considerados improdutivos, e tem como objetivo sancionar o proprietário que não cumpre o dever social da propriedade.

Outra modalidade consiste na desapropriação para fins urbanísticos, que se baseia na função da propriedade urbana, cujas características tratamos no capítulo 2 deste trabalho. 
A desapropriação para fins ambientais não possui um rito específico, mas tem previsão no interesse social conforme art. $2^{\circ}$., inciso VI da Lei ${ }^{\circ} .4 .132$, de 10 de setembro de 1962:

\author{
"Art. $2^{\circ}$ Considera-se de interesse social: \\ $(\ldots)$ \\ VII - a proteção do solo e a preservação de cursos e mananciais de \\ água e de reservas florestais."
}

\title{
3.2 Diferenças entre desapropriação urbanística e desapropriação comum
}

Silva (2006, p. 401) ao tratar da desapropriação urbanística preceitua:

\begin{abstract}
“A desapropriação urbanística distancia-se desse conceito geral, para caracterizar-se como um instrumento de realização da política do solo urbano em função da execução do planejamento urbanístico. Nesse sentido é que se afirma que ela consubstancia um instrumento de execução da atividade urbanística do Poder Público, que tem no planejamento seu princípio nuclear. Ora, esse planejamento, ao estabelecer as bases da ordenação da realidade urbana, importa conformar e configurar a propriedade imóvel e o direito de construir, atuando no plano prático, o principio constitucional da função social da propriedade. Pois bem, os proprietários de imóveis urbanos nem sempre estarão dispostos a aceitar os condicionamentos estabelecidos nos planos para a sua propriedade; por isso, é tarefa da atividade urbanística fazer com que essas propriedades sejam encaminhadas para a utilização neles previstas".
\end{abstract}

No caso das desapropriações urbanísticas, ao contrário das desapropriações comuns, ou seja, aquelas cuja finalidade é a utilidade pública, é possível ao Poder Público dar outras destinações às áreas desapropriadas, em razão de sua função renovatória em áreas já urbanizadas e até a utilização de prédios rústicos para fins de urbanizá-los. E ainda, a possibilidade de desapropriação de áreas maiores do que na desapropriação tradicional (SILVA, 2006). 
$\mathrm{O}$ art. $5^{\circ}$. do Decreto-Lei $\mathrm{n}^{\circ}$. 3.365, de 21 de julho de 1941, trata de várias hipóteses de desapropriações para fins urbanísticos. Primeiramente verifica-se a alínea “d”, referente aos casos de salubridade pública.

Neste sentido:

"Salubridade é a qualidade do que é salubre, saudável, higiênico. Sob esta designação, estão compreendidas obras com o objetivo de dotar o meio ambiente desta qualidade. Desta forma, a titulo exemplificativo, regiões pantanosas, cujas emanações putrefatas tornem o ar impróprio para a saúde, poderão ser desapropriadas para a execução de obras de drenagem e saneamento. As mesmas obras podem ser necessárias em áreas atingidas permanentes por epidemias, cuja erradicação não se possa fazer sem o afastamento daqueles que vivem no local" (PINHEIRO, 2004, p.80).

Já na alínea "e", o Decreto-Lei trata da "criação e melhoramento de centros de população, seu abastecimento regular de meios de subsistência”. Tal alínea foi prevista para possibilitar ao Poder Público realizar o desenvolvimento de regiões desfavorecidas em face do restante do país, criando os chamados "núcleos de colonização" (SALLES, 2006).

$\mathrm{Na}$ alínea " $\boldsymbol{~}$ ” o dispositivo legal elucida: “a abertura, conservação $e$ melhoramento de vias ou logradouros públicos; a execução de planos de urbanização; o parcelamento do solo, com ou sem edificação, para sua melhor utilização econômica, higiênica ou estética; a construção ou ampliação de distritos industriais”.

Nesta alínea verificam-se quatro possibilidades de desapropriação para fins urbanísticos. A primeira consiste na "abertura, conservação e melhoramento de vias e logradouros públicos”.

Meirelles (2002, p. 377) afirma a este respeito:

"As terras ocupadas com as vias e logradouros públicos pertencem às Administrações que os construíram. Tais áreas podem constituir bens de uso comum do povo ou bens de uso especial. Presentemente, as ruas e estradas admitem 
discriminação de uso, contrariando a regra expressa no inc. I, do art.66 do CC que, ao seu tempo, desconhecia as limitações de trânsito e tráfego modernamente estabelecidas para as vias de circulação. Estradas há que, embora de domínio público, são reservadas a determinadas utilizações ou a certos tipos de veículos, tendo em vista a sua destinação ou o seu revestimento; noutras o uso é pago, mediante tarifa de pedágio ou rodágio; noutras o trânsito é condicionado a horário ou a tonelagem máxima, o que as tornam verdadeiros instrumentos administrativos, de uso especial, sem a generalidade das utilizações do passado que as caracterizam como bens de uso comum de todos. As mesmas observações valem para as áreas de terrenos ocupadas pelas estradas de ferro".

A segunda situação apontada pela alínea "i” refere-se à “execução de planos de urbanização". Esta modalidade é sem dúvida a mais abrangente, pois permite intervenções pontuais, mesmo que não prevista no planejamento urbano do território, situação infelizmente não pouco rara.

Sobre tal modalidade de desapropriação, Mello (1997, p. 353) salienta:

\begin{abstract}
"Todos sabem de sobejo, que a teia urbana compõe tecido de extrema delicadeza, pelas múltiplas relações que se estabelecem entre as várias células da cidade. Não se pode, salvo talvez excepcionalmente, tocar uma sem afetar outra, pois um processo de reação em cadeia se deflagra alterando o equilíbrio de vários setores da urbe [...] Assim modelar, ou remodelar uma ponta da cidade afeta tudo que lhe é circunvizinho".
\end{abstract}

A terceira e quarta situações estabelecidas consistem no "parcelamento, do solo, com ou sem edificação, para sua melhor utilização econômica, higiênica e estética; ampliação de distritos industriais”. Nesta alínea é previsto o loteamento de glebas urbanas com a finalidade de propiciar habitação à população de baixa renda, assim como criação e expansão de zonas industriais.

$\mathrm{Na}$ alínea " $\mathrm{j}$ ” o dispositivo legal afirma: "o funcionamento dos meios de transporte coletivo". Já a alínea " $k$ ” prevê, “a preservação e conservação dos monumentos históricos e artísticos, isolados ou integrados em conjuntos urbanos ou rurais, bem como as medidas necessárias a manter-lhes e realçar-lhes os aspectos mais valiosos ou 
característicos e, ainda, a proteção de paisagens e locais particularmente dotados pela natureza". Nestes casos, se utiliza a expropriação por parte do Poder Público quando o proprietário não detiver meios para a manutenção do bem em questão.

E a última alínea, "n”, trata da "criação de estádios, aeródromos ou campos de pouso para aeronaves”.

Quanto às desapropriações decorrentes de interesse social previstas na Lei $n^{\circ}$. 4.132, de 10 de setembro de 1962, podemos inferir que são ocasionadas devido à ausência de exercício da função social do bem em questão, conforme analisaremos abaixo. Neste sentido "qualquer atividade econômica, agrícola, comercial ou industrial que não esteja cumprindo sua função social por se constituir em fonte de desequilíbrio urbano pode ser objeto de desapropriação" (DALLARI, 1981, p.97).

As desapropriações desta modalidade encontram-se insertas no art. $2^{\circ}$. da Lei $n^{\circ}$. 4.132, de 10 de setembro de 1962. Em seu primeiro inciso apresenta-se da seguinte forma, "o aproveitamento de todo bem improdutivo ou explorado sem correspondência com as necessidades de habitação, trabalho e consumo dos centros de população a que deve ou possa suprir por seu destino econômico".

O inciso III trata da necessidade de manutenção de colônias ou cooperativas de povoamento ou trabalho agrícola. Há de se ressalvar que a idéia de Cidade não mais deve ser compreendida como antônimo de rural, mas sim se devem integrar todas as políticas de ocupação a ambas as regiões.

O inciso IV prevê “a manutenção de posseiros em terrenos urbanos onde, com a tolerância expressa ou tácita do proprietário, tenham construído sua habitação, formando núcleos residenciais de mais de 10 (dez) famílias”. Tal dispositivo possibilita a resolução de 
conflitos fundiários especificados como um dos maiores problemas habitacionais brasileiros em âmbito urbano, as denominadas "favelas", possibilitando a garantia da segurança da posse de seus moradores.

Já o inciso V trata da “construção de casas populares”, enquanto que o inciso VI dispõe sobre "terras e águas suscetiveis de valorização extraordinária, pela conclusão das obras e serviços públicos, notadamente de saneamento, portos, transporte, eletrificação, armazenamento de água e irrigação, no caso em que não sejam ditas áreas socialmente aproveitadas". E seguindo a mesma lógica, o inciso VII prevê as situações de "proteção ao solo e preservação de cursos e mananciais de água e reservas florestais”. E por fim o inciso VIII que trata da "a utilização de áreas, locais ou bens que, por suas características, sejam apropriados ao desenvolvimento de atividades turísticas”.

Contudo, notamos que a Lei $\mathrm{n}^{\mathrm{o}}$. 4.132, de 10 de setembro de 1962 no que concerne às desapropriações baseadas no descumprimento da função social urbana só pode ser entendida como recepcionada pela Constituição Federal de 1988, se aplicada, cumulativamente, as regras do artigo 182 do Constituição, as do Estatuto da Cidade e as que o plano diretor municipal definir.

Diante disto, uma questão importante a se colocar é sobre a possibilidade do Município que não possui plano diretor basear-se na Lei nº ${ }^{\circ}$ 4.132, de 10 de setembro de 1962 para desapropriar área que não atende função social da propriedade urbana.

Primeiramente temos que a idéia trazida com a lei que estabelece a desapropriação por interesse social está consideravelmente defasada em relação aos instrumentos urbanísticos que surgiram nos últimos anos disciplinados tanto pela Constituição Federal de 1988 como pelo Estatuto da Cidade. 
Com efeito, estabelece o art. $1^{\circ}$ da Lei $\mathrm{n}^{\circ} .4 .132$, de 10 de setembro de 1962:

“Art. $1^{\circ}$. A desapropriação por interesse social será decretada para promover a justa distribuição da propriedade ou condicionar o seu uso ao bem estar social, na forma do art. 147 da Constituição Federal."

O Estado delineado pela Constituição Federal de 1988 possui feição reguladora, tendo em vista a falência do modelo de Estado Social capaz de suprir as necessidades de todos, em função de suas limitações financeiras e econômicas. ${ }^{17}$

O Estado atual não possui capacidade financeira para propiciar a justa distribuição da propriedade. Se a Constituição Federal de 1988 e o Estatuto da Cidade estabeleceram um novo marco legal em termos de regulação da propriedade urbana, um entendimento razoável a respeito desta nova ordem é o de que o Poder Público deve buscar no planejamento e nos novos instrumentos urbanísticos uma nova perspectiva para o instrumento da desapropriação.

A idéia é a de os Municípios planejem sua atuação de intervenção no território, inclusive nos casos de desapropriação, situação que não se coaduna com a decisão de desapropriar sem planejamento, seja por utilidade pública, seja por interesse social. Neste último caso, interesse social, a situação se agrava se o Poder Público fundamentar a decisão em descumprimento da função social da propriedade sem que a mesma esteja definida em seu plano diretor, principalmente considerando que a Constituição Federal e Estatuto da Cidade estabelecem desapropriação específica quando ausente a função social da propriedade, qual seja, a desapropriação-sanção supra analisada.

\footnotetext{
${ }^{17}$ Neste sentido, Segundo (LÔBO, 2000),

"Entende-se por Estado social, no plano do direito, todo aquele que é regido por uma Constituição que regule a ordem econômica e social. Nesse sentido, substituiu o Estado liberal, cuja constituição voltava-se à delimitação do poder político ou à organização política e à garantia dos direitos individuais, com pouca intervenção nas relações de mercado." A crise do Estado social foi deflagrada pela constatação dos limites das receitas públicas para atendimento das demandas sociais, cada vez crescentes. Portanto, a crise situa-se na dimensão da ordem social insatisfeita (garantia universal de saúde, educação, segurança, previdência social, assistência aos desamparados, sobretudo), ou do Estado providência. Mas, na medida em que o Estado substitui seu papel de empreendedor para o de regulador da atividade econômica, permanece intacta a natureza intervencionista da ordem econômica constitucional, ou a "mão visível" do Estado. Temos, pois, uma forte tendência em substituir o Estado de bem-estar para o Estado regulador, enquanto for necessária essa função de garantia das regras do jogo das forças econômicas.
} 
Países como Espanha, Itália, França e Portugal, em que o direito urbanístico é bastante avançado em relação ao direito urbanístico pátrio, a desapropriação urbanística goza de regime jurídico próprio, diferenciado daquele adotado para os casos gerais.

$\mathrm{Na}$ Espanha, por exemplo, a matéria é disciplinada pela atual Ley del Suelo, Ley 6/1998, que prevê:

\footnotetext{
“Artículo 4.

Acción urbanística e iniciativa privada

1. Los propietarios deberán contribuir, en los términos establecidos en las leyes, a la acción urbanística de los entes públicos, a los que corresponderá, en todo caso, la dirección del proceso, sin perjuicio de respetar la iniciativa de aquéllos.

2. La gestión pública a través de su acción urbanizadora y de las políticas de suelo suscitará, en la medida más amplia posible, la participación privada.

3. En los supuestos de actuación pública, la Administración actuante promoverá, en el marco de la legislación urbanística, la participación de la iniciativa privada aunque ésta no ostente la propiedad del suelo".
}

Quanto aos fundamentos da aplicação da expropriação no âmbito urbanístico, a leis espanhola prevê em seu art. $4^{\circ}$.

"La expropiación por razón de urbanismo podrá aplicarse de acuerdo con las finalidades previstas en la legislación urbanística y, asimismo, por incumplimiento de la función social de la propiedad, con los requisitos previstos en la Ley de expropiación forzosa."

Contudo, no Brasil, verifica-se que as hipóteses de desapropriação urbanísticas encontram fundamento em diplomas legais distintos, o que dificulta a formação de uma teoria geral e a configuração de um regime jurídico próprio. Entretanto, dada a importância do fenômeno da urbanização, bem como da eficiência e indispensabilidade do instrumento da desapropriação para ordenar os espaços habitáveis, torna-se necessário a edição de lei que trate especificamente de suas modalidades, e discipline as suas peculiaridades, principalmente, os aspectos atinentes aos sujeitos desapropriantes, à revenda e à indenização (PINHEIRO, 2004). 


\subsection{Procedimentos de avaliação}

Ao tratar da perícia no feito expropriatório verifica-se a existência de normas referentes ao tema no Código de Processo Civil, nos artigos referentes ao perito: arts. 145 a 147; e à prova pericial: arts. 420 a 439. É importante ressaltar, que, conjuntamente com o Código de Processo Civil, se deve analisar o Decreto-Lei nº 3.365, de 21 de julho de 1941, em especial junto aos dispositivos 14, 23 e 27.

Inicialmente há que se transcrever os artigos referentes à perícia presentes na Lei de Desapropriação para a plena compreensão de sua extensão. No artigo 14, a lei dispõe "Ao despachar a inicial, o juiz designará um perito de sua livre escolha, sempre que possível técnico, para proceder à avaliação dos bens. Parágrafo único. O autor e o réu poderão indicar assistente técnico ao perito".

Neste artigo verifica-se que logo que despachada a inicial o juiz deverá proceder com a escolha de um perito, no caso, o próprio dispositivo não exige a tecnicidade do escolhido, apenas se não houver possibilidade de escolha de um perito técnico. Sobre esta temática, Salles (2006, p. 307) afirma: “A escolha do perito, como dissemos anteriormente, deve recair em técnico, sempre que possível (art.14 do Decreto-Lei no . 3.365, de 21 de julho de 1941). Vale dizer: quando não for possível, o juiz poderá indicar pessoa leiga para proceder à perícia na ação expropriatória”.

Fagundes (1949, p. 203) contempla duas situações nas quais se deve recorrer a um perito não técnico. A primeira em casos de inexistência de perito técnico no local, e a segunda é que mesmo havendo o perito, aos olhos do juiz ele não seja considerado idôneo. E ainda afirma: "a idoneidade pessoal não vale menos que a competência técnica, e, se a ausência 
desta pode conduzir a resultados imprecisos e deficientes, a ausência daquela pode levar a conclusões desonestas e absolutamente contrárias à finalidade da perícia”.

O parágrafo único do dispositivo introduzido permite-se as partes do litígio determinar auxiliares ao perito. Essa autorização legal é concedida devido às partes muitas vezes encontrarem-se na mesma situação do magistrado, que desconhece as especificidades técnicas do litígio, podendo recorrer a um perito para prestar tais esclarecimentos. $\mathrm{O}$ assistente técnico tem por função auxiliar as partes que lhe indicaram, da mesma forma que o perito auxilia o juiz.

Neste aspecto, Salles (2006, p. 318) afirma que a função do assistente extravasa tal função, tendo também o poder de criticar o laudo do perito, apontar suas falhas e incoerências.

Ainda acerca das atribuições desenvolvidas pelo assistente técnico, assevera Fagundes (1949, p.210):

\begin{abstract}
“Conhecido o laudo elaborado pelo perito cabe-lhe esquadrinhá-lo e impugná-lo nas suas falhas, fornecendo ao advogado, por escrito ou verbalmente, elementos de discussão, e, diretamente ou por intermédio deste, esclarecer o juiz a propósito dos defeitos ou da segurança das conclusões periciais, em função do ponto de vista da parte que o tenha indicado. O seu papel será relevantíssimo para a exata avaliação do bem expropriando, dependendo, muitas vezes, do critério, da ponderação e da competência técnica, que revele a obtenção de sentença acolhendo o ponto de vista da parte respectiva. O juiz, ao decidir, não pode deixar de ter em consideração também as suas objeções e pontos de vista, dando-lhes o valor que merecerem segundo o seu mérito intrínseco e a idoneidade pessoal e técnica do assistente
\end{abstract}

Conforme se depreende da análise do renomado autor brasileiro, a ausência de critérios avaliatórios para se chegar a um valor justo de indenização já está consolidada no sistema brasileiro. O autor chega a afirmar que o papel do assistente técnico é a de esclarecer o juiz segundo o ponto de vista da parte que o tenha indicado e a que o juiz deve considerar a idoneidade pessoal e técnica do assistente. 
Vale ressaltar, que a idoneidade é relevante, mas a existência de parâmetros objetivos de avaliação eliminaria, em grande parte, o subjetivismo dos laudos.

O parágrafo único presente no artigo 14 da Lei de Desapropriação encontra seu correspondente no art. 421, $\S 1^{\circ}$, I que afirma: “O juiz nomeará perito, fixando de imediato o prazo para a entrega do laudo. $\S 1^{\circ}$. Incumbe às partes, dentro de cinco (05) dias, contados da intimação do despacho de nomeação do perito: I - indicar assistente técnico; (...)".

Para Salles (2006, p. 308) os assistentes técnicos são na verdade consultores das partes, e exatamente pelo fato de serem pessoas da plena confiança delas, não estão eles sujeitos a nenhuma espécie de impedimentos ou suspeição.

Na verdade, o fato dos assistentes técnicos defenderem exclusivamente o interesse das partes contribui para que em um mesmo processo possa haver três laudos de valores muito discrepantes, situação que corrobora para a morosidade de uma decisão judicial a respeito de uma indenização justa.

Contudo, há de se ressaltar que apenas o perito se encontra na condição de ser afastado ou mesmo recusar-se de efetuar a perícia, em casos de impedimento ou suspeição, como preceitua o artigo 423 do Código de Processo Civil. Nesses casos caberá ao juiz a escolha de novo perito.

O dispositivo 23 da Lei afirma:

"Findo o prazo para a contestação e não havendo concordância expressa quanto ao preço, o perito apresentará o laudo em cartório, até cinco dias, pelo menos, antes da audiência de instrução e julgamento. $\S 1^{\circ}$. O perito poderá requisitar das autoridades públicas os esclarecimentos ou documentos que se tornem necessários à elaboração do laudo, e deverá indicar nele, entre outras circunstancias atendíveis para a fixação da indenização, as enumeradas no artigo 27. Ser-lhe-ão abonadas, como as custas, as despesas com certidões e, a arbítrio do juiz, as de outros documentos que juntar ao laudo. $\S 2^{\circ}$. Antes de proferido o despacho saneador, poderá o perito solicitar prazo especial para apresentação do laudo”. 
E por fim o artigo 27 dispõe:

“O juiz indicará na sentença os fatos que motivaram o seu convencimento e deverá atender, especialmente, à estimação dos bens para efeitos fiscais; ao preço de aquisição e interesse que deles aufere o proprietário; à sua situação, estado de conservação e segurança; ao valor venal dos da mesma espécie, nos últimos cinco anos, e à valorização ou depreciação de área remanescente, pertencente ao réu. (...)"

A necessidade de um perito nas ações judiciais surge devido ao esparso conhecimento específico do magistrado frente às peculiaridades aos mais variados temas discutidos no Judiciário. Ao magistrado cabe ser um profundo conhecedor da lei, e não das especificidades de cada caso concreto.

Assim, a figura do perito surge na atividade jurisdicional para auxiliar o magistrado na compreensão da relação jurídica discutida pelas partes. O juiz utiliza-se dos conhecimentos técnicos de outra pessoa para formar seu convencimento.

Para Barbi (1975, p. 121):

\begin{abstract}
"a análise levada a efeito pelos modernos processualistas mostrou que o perito é um auxiliar do juiz, para colaborar no exame de coisas ou pessoas, quando faltarem a este conhecimento técnico para isso. A rigor, teoricamente falando, deveria o próprio juiz fazer esse exame, mas as circunstâncias já indicadas o levam a recorrer ao auxilio de pessoa mais entendida no assunto, a qual relatará o que viu e apresentará suas conclusões ao magistrado".
\end{abstract}

Deve-se acrescentar que o perito auxilia o juiz na matéria técnica da qual depende a resolução do litígio. Contudo, o juiz não está vinculado ao laudo pericial para realizar sua decisão, podendo formar livremente sua convicção por outros meios de prova, como estabelece o Código de Processo Civil em seu artigo 436. ${ }^{18}$

18 Para Emílio Haddad, em seu trabalho, "Comentários sobre os procedimentos utilizados no estabelecimento do
valor de indenização de bens imóveis desapropriados pelo poder público, 2000.http://territorioysuelo.org, seria
recomendável a criação de tribunais especializados para julgamento de processos de desapropriação de bens
imóveis, a exemplo do que ocorre na França, e cita o depoimento do “juge de l'expropriation", Francis Catalano,
que atua na região de Alpes Maritimes, para quem a especialização regional facilita o conhecimento mais
próximo e detalhado dos agente imobiliários do local e a dinâmica do mercado ali existente. "Le rôle du juge de 
O artigo 424 do Código de Processo Civil apresenta o rol de causas em que o perito poderá ser substituído, e dispõe: “O perito pode ser substituído quando: I - carecer de conhecimento técnico ou cientifico; II - sem motivo legítimo, deixar de cumprir o encargo no prazo que lhe foi assinado. Parágrafo único. No caso previsto no inciso II, o juiz comunicará a ocorrência à corporação profissional respectiva, podendo, ainda, impor multa ao perito, fixada tendo em vista o valor da causa e o possível prejuízo decorrente do atraso no processo”.

A previsão legal que admite a realização de perícia por não técnicos nos casos de processos expropriatórios, longe de supor, não pressupõe que o designado perito seja incapaz de efetuar o que lhe foi delegado.

Salles (2006, p. 309) ao tratar do dispositivo da lei de desapropriação que possibilita a perícia efetuada por pessoa não técnica afirma:

\footnotetext{
“o que se pretende é que o perito nomeado, apesar de não ser técnico na matéria que lhe seja submetida a exame, tenha pelo menos a competência necessária para, suprindo suas deficiências, encontrar o valor correto do bem expropriando, de modo a preencher no patrimônio do expropriado a lacuna gerada pela desapropriação".
}

De acordo com o art. 146 do Código de Processo Civil, ao perito é fixado um prazo para a concretização da perícia. Poderá contanto, se eximir da obrigação mediante justo motivo. Nestes casos, o artigo supracitado preceitua que o perito tem o prazo de cinco dias, contados da intimação ou do motivo de impedimento. Se não realizado em tal prazo, não caberá a escusa.

l'expropriation", Études Fonciers, Paris: ADEF, disponível na página


Quanto ao conteúdo do laudo pericial, há a exigência de informações providas de veracidade. Salles (2006, p. 310):

\begin{abstract}
"Assinale-se, ainda, que o perito tem o dever de prestar informações verídicas. Por isso, aquele que, por dolo ou culpa, prestar informações inverídicas, responderá pelos prejuízos que causar a outra parte, ficará inabilitado, por dois anos, a funcionar em outras perícias e incorrerá na sanção que a lei penal estabelecer (art. 147 do CPC e 342 do Código Penal)".
\end{abstract}

O art. 420 do Código de Processo Civil conceitua a prova pericial como sendo o exame, vistoria ou avaliação. No caso das ações expropriatórias cabe a perícia consistente na avaliação do bem discutido na ação.

O entendimento de Salles (2006, p. 311) para o tema consiste:

\begin{abstract}
"Por outro lado, parece-nos que a avaliação dos bens expropriados deverá ser feita sempre, por força dos termos imperativos constantes dos arts. 14 (caput) e 23 (caput) do Dec.-lei 3.365/1941, que é lei especial sobre desapropriações. Entendemos, pois, que não incide, subsidiariamente, na espécie, o disposto no art. 427 do CPC (redação dada pela Lei 8.455 de 24.08.1992), segundo o qual "o juiz poderá dispensar prova pericial quando as partes, na inicial e na contestação, apresentarem sobre as questões de fato pareceres técnicos ou documentos elucidativos que considerar suficientes". No feito expropriatório, segundo entendemos, tais pareceres e documentos poderão servir apenas como inicio de prova, sendo indispensável a realização de perícia (RSTJ 88/37, RT 734/270 e Boletim do STF 12 de 30.08 .1996 p.44)”.
\end{abstract}

Relativamente ao conteúdo dos laudos de avaliação, verificamos que a legislação brasileira atribui muito poder ao perito, silenciando a respeito de padrões mínimos que deverão ser observados na realização da perícia, fato que tem propiciado a produção de laudos muito subjetivos e com valores muito discrepantes em relação a outros realizados para áreas com as mesmas características.

Neste tema, julgamos importante o disposto pela legislação Colombiana, Decreto 1420/1998, que é bem eficiente ao estabelecer padrões objetivos que deverão ser considerados pelo perito: 
“ARTICULO 20. Se entiende por valor comercial de un inmueble el precio más probable por el cual éste se transaría en un mercado donde el comprador y el vendedor actuarían libremente, con el conocimiento de las condiciones físicas y jurídicas que afectan el bien.

\section{$(\ldots)$}

CAPITULO IV.

DE LOS PARAMETROS Y CRITERIOS PARA LA ELABORACION DE AVALUOS

ARTICULO 20. El Instituto Geográfico Agustín Codazzi, la entidad que cumpla sus funciones y la personas naturales o jurídicas registradas y autorizadas por las lonjas en sus informes de avalúo, especificarán el método utilizado y el valor comercial definido independizando el valor del suelo, el de las edificaciones y las mejoras si fuere el caso, y las consideraciones que llevaron a tal estimación.

$(\ldots) "$

A legislação colombiana, além de conceituar o valor comercial do imóvel em seu art. $2^{\circ}$., a partir do art. 20 estabelece critérios a serem seguidos pelos avaliadores, deixando claro para todos os envolvidos quais são os fatores que serão levados em consideração para se fixar o valor da indenização, conferindo maior segurança aos laudos de avaliação.

Do mesmo modo procede a legislação espanhola, que estabelece critérios para cada tipo de solo, classificando-o em urbanizável e não urbanizável, situação esta que traz segurança aos particulares relativamente à atuação do Estado diante de suas propriedades. Abaixo transcrevemos os critérios observados em avaliação de solo urbanizável.

"Ley 6/1998, de 13 de abril, sobre régimen del suelo y reglas de valoración:

Artículo 27.

Valor del suelo urbanizable

1. El valor del suelo urbanizable incluido en ámbitos delimitados para los que el planeamiento haya establecido las condiciones para su desarrollo se obtendrá por aplicación al aprovechamiento que le corresponda del valor básico de repercusión en polígono, que será el deducido de las ponencias de valores catastrales. En el supuesto de que la ponencia establezca para dicho suelo valores unitarios, el valor del suelo se obtendrá por aplicación de éstos a la superficie correspondiente. De dichos valores se deducirán los gastos que establece el artículo 30 de esta Ley, salvo 
que ya se hubieran deducido en su totalidad en la determinación de los valores de las ponencias. (...)

En cualquier caso, se descartarán los elementos especulativos del cálculo y aquellas expectativas cuya presencia no esté asegurada”.

No Brasil, repita-se, a ausência na lei de dispositivos específicos para o caso de avaliação de imóveis, em particular no caso de desapropriações, é fator que dificulta ao Poder Judiciário analisar os resultados dos laudos apresentados e gera discussões intermináveis a respeito do quantum a ser indenizado ao expropriado

Outro ponto de relevância para a compreensão da perícia no feito expropriatório consiste no momento em que o juiz deverá indicar o perito. $\mathrm{O}$ art. 14 anteriormente citado da Lei de Desapropriações estabelece que o momento adequado para a indicação deva ser efetuado junto com o pedido de citação do réu no despacho da petição inicial pelo juiz.

Em nossa pesquisa, verificamos que no caso da experiência da Fazenda Pública da Comarca de São Paulo, o momento da perícia é adiantado para o início do processo com a finalidade de recompor boa parte do patrimônio perdido mais rapidamente.

Muito embora o Decreto-Lei $\mathrm{n}^{\circ}$. 3.365, de 21 de junho de 1941, em seu art. 14, determine que o juiz, ao despachar a inicial, deva nomear o perito, ${ }^{19}$ essa providência tem sua concretização muito demorada, por isso, os Juízes da Vara da Fazenda Pública da Comarca de São Paulo criaram o procedimento de se determinar a realização de laudo prévio, logo no início do processo judicial. Para uma melhor compreensão, verificar o capítulo 6 deste trabalho.

\footnotetext{
${ }^{19}$ Para uma aplicação mais eficiente do direito, é fundamental a determinação de um procedimento objetivo, circunstância que se evidencia no estudo da desapropriação, cuja lacuna procedimental é muito grande. Esse é um problema observado também em outros países e ramos do direito. Neste sentido, Azuela (2006, p. 506) "Para entender estos problemas, há sido indispensable recuperar la idea de la procedimentalización del derecho, pues con ella entendemos que las normas jurídicas solo adquieren un sentido concreto (es decir, sólo forman parte de la experiencia práctica) en el contexto de un procedimiento".
} 
O perito, ao realizar a avaliação dos bens objeto da expropriação está sujeito aos quesitos formulados pelo juiz ou pelas partes, ou seja, as questões formuladas referentes aos fatos da ação. Os quesitos devem ser oferecidos pelas partes no mesmo prazo constante para a nomeação de assistentes técnicos.

Nesse tema Salles (2006, p. 214) informa:

"Os quesitos objetivam, destarte, delimitar o âmbito da perícia. Por isso, observando
os fatos, apreciando-os em suas consequiências e chegando a determinadas
conclusões, os peritos e assistentes técnicos vão respondendo aos quesitos
apresentados pelas partes ou formulados pelo juiz, levando a cabo, assim, a missão
que lhes foi atribuída".

O laudo pericial, diante da discordância do preço entre autor e réu e de acordo com o artigo 23 da Lei de Desapropriação, deve ser oferecido no prazo de 5 (cinco) dias antes da audiência de instrução e julgamento. Por analogia, os pareceres dos auxiliares técnicos também ficam submetidos ao mesmo prazo.

Nos casos de não entrega do laudo, o perito em questão estará sujeito ao que preceitua o artigo 424 do Código de Processo Civil, podendo ser substituído.

Já o artigo 429 do mesmo diploma legal trata dos meios lícitos para o perito formular e embasar seu laudo. Neste dispositivo é autorizado ao perito ou aos assistentes, se valerem de quaisquer meios (testemunhas, informações, documentos, etc.), e se utilizar de quaisquer métodos para expressar as informações no laudo (desenhos, fotografias, plantas, etc.). Este artigo encontra correspondência na Lei de Desapropriação, no $\S 1^{\circ}$ do art. 23, que preceitua: "o perito poderá requisitar das autoridades públicas os esclarecimentos ou documentos que se tornarem necessários à elaboração do laudo, e deverá indicar nele, entre outras circunstâncias atendíveis para a fixação da indenização, as enumeradas no art. 27’. 
Contudo, mesmo que o juiz não esteja vinculado ao laudo oferecido pelo perito, este é determinante para a formação de da convicção do magistrado. Dessa forma, é de rigor que o laudo contenha pontos de relevância.

Destarte, na legislação brasileira, o Decreto-lei no 3.365, de 21 de junho de 1941, estabelece critérios muito simples a serem observados pelo juiz no momento da fixação da indenização, não distinguindo o tipo de solo, nem se referindo à observância de legislação urbanística:

\footnotetext{
“Art. 27. O juiz indicará na sentença os fatos que motivaram o seu convencimento e deverá atender, especialmente, à estimação dos bens para efeitos fiscais; ao preço de aquisição e interesse que deles aufere o proprietário; à sua situação, estado de conservação e segurança; ao valor venal dos da mesma espécie, nos últimos cinco anos, e à valorização ou depreciação de área remanescente, pertencente ao réu".
}

Com base nesses valores fixados na perícia, que não costumam sofrer nenhum questionamento por parte do Poder Judiciário, são aplicados juros moratórios, compensatórios e correção monetária, elementos que, somados, totalizam o valor final da indenização ${ }^{20}$. Assim, a despeito de se questionar a incidência das taxas de juros sobre o valor arbitrado pela perícia, o problema maior é conhecer-se que caminhos foram percorridos pelos peritos para se atribuir o valor à propriedade, o que gera distorções ainda maiores com a aplicação das taxas de juros e da correção monetária.

\subsection{Conclusões: necessidade de legislação específica}

O presente trabalho tem, entre seus propósitos, refletir sobre a necessidade de se consolidar um novo modo de pensar sobre o instituto da desapropriação como instrumento de política urbanística e, também, ambiental. ${ }^{21}$

\footnotetext{
${ }^{20}$ Para um melhor entendimento da composição do valor final da indenização ver Capítulo 6

${ }^{21}$ Preocupação tratada nas obras de Dallari (1981) e Silva (2006)
} 
Como já mencionado, a fundamentação legal da desapropriação tradicional decorre do Decreto-Lei ${ }^{\circ}$. 3.365, de 21 de junho de 1941 e Lei ${ }^{\circ}$. 4.132, de 10 de setembro de 1962 e tratam, respectivamente, de desapropriação por utilidade pública e por interesse social. No entanto, quando utilizada pelo Poder Público como execução de atividade urbanística recebe a denominação de desapropriação urbanística e, nesse campo, ela excede seu conceito tradicional, com notáveis diferenças relativamente à desapropriação geral (SILVA, 2006).

O Estatuto da Cidade, Lei Federal Lei n ${ }^{\circ}$ 10.257, de 10 de julho de 2001, dispõe que a desapropriação é um instrumento jurídico da política urbana. Através dele regulamentou-se a desapropriação-sanção prevista no art. $8^{\circ}$, não a urbanística, que continua sendo regida pelas normas gerais de desapropriação, especificamente pelo que prevê o art. $5^{\circ}$,

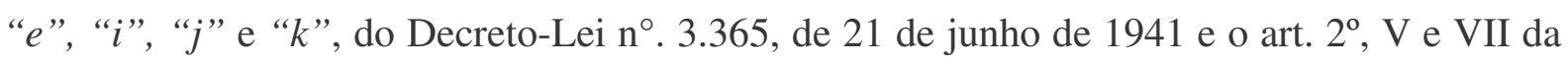
Lei $\mathrm{n}^{\mathrm{o}}$. 4.132, de 10 de setembro de 1962.

Do mesmo modo, não há um tratamento legal específico para as desapropriações de caráter ambiental, que encontram fundamento apenas no art. $2^{\circ}$, VII da Lei $n^{\circ} .4 .132$, de 10 de setembro de 1962.

Sem embargo, dentre os principais instrumentos contemplados no Estatuto da Cidade, a desapropriação é provavelmente o que mereceu o tratamento mais lacônico. Talvez porque sua prática já se encontrasse de certa forma estabelecida em nosso meio ou porque houve certa ênfase daquela lei aos chamados "novos" instrumentos com conteúdo arrecadatório, como, por exemplo, a outorga onerosa do direito de construir.

Assim, ao comentar a ausência de unidade legislativa para se tratar o tema da desapropriação urbanística, Silva (2006, p. 185): 


\begin{abstract}
“A aspiração de unidade legislativa fracassa redondamente. Nos aspectos puramente procedimentais e nos mais substanciais dos critérios de valoração, quando se trata de urbanismo, pouco ou nada há que acudir-se àquela lei geral. Há de acudir-se a uma série de disposições que integram o ordenamento jurídico sobre solo e ordenação urbana".
\end{abstract}

Diante do quadro exposto no presente trabalho, temos que o raciocínio também deve ser utilizado para as chamadas desapropriações ambientais, pois como pôde ser verificado nos processos de desapropriações ambientais da Serra do Mar, a utilização dos mesmos critérios de valoração empregados nos processos de desapropriações comuns, ou seja, de utilidade pública ou de interesse social, geraram profundas distorções no valor fixado na indenização final.

Com efeito, o problema da indenização nas desapropriações urbanísticas é objeto de tratamento bem cuidadoso no direito comparado, em que leis urbanísticas estabelecem critérios especiais para a fixação de justo preço, tema extremamente controvertido entre os estudiosos e a jurisprudência brasileira.

A legislação espanhola e a colombiana, por exemplo, fixam procedimentos e técnicas de valoração nas desapropriações urbanísticas e estabelecem um rol de critérios que visam a atender os seguintes princípios: que a qualificação urbanística do solo condiciona seu aproveitamento e, portanto, seu valor econômico; que as mais-valias procedem de obra de urbanização ou mudanças nas leis de uso do solo e que a atribuição destas mais-valias será cabível quando o proprietário haja custeado como deve, a urbanificação.

Se as desapropriações urbanísticas têm um relevo diferenciado relativamente às desapropriações comuns, principalmente no tocante à valoração dos terrenos envolvidos, as ambientais possuem características ainda mais especiais. Mesmo porque, as características peculiares dessas regiões muitas vezes não encontram qualquer parâmetro. 
Em face da Constituição Federal de 1988, não há um direito de propriedade que confira ao seu titular a opção de usar aquilo que lhe pertence de modo a violar os princípios hoje estampados nos arts. $5^{\circ}, 170$, inciso VI, 184, $\S 2^{\circ}$, 186, inciso II, e 225 , todos da Constituição Federal. A propriedade privada, nos moldes da Lei Maior vigente, abandona, de vez, sua configuração essencialmente individualista para ingressar em uma nova fase, mais civilizada e comedida, onde se submete a uma ordem ambiental.

É nesse contexto em que a propriedade tem de cumprir uma função sócioambiental que as valorações, para efeito de indenização, devem guardar consonância com as mudanças desses paradigmas. Assim, considerando que a noção tradicional de desapropriação evoluiu e passa a ser vista como instrumento urbanístico e ambiental, muda a perspectiva também dos cânones de avaliação tradicionalmente utilizados na desapropriação comum. 


\section{Capítulo 4}

\section{JUSTO VALOR E SUA INDENIZAÇÃO}

$\mathrm{Na}$ seqüência do entendimento dos aspectos que compõem a indenização em processo de desapropriação, após a análise do modelo seguido e seu correspondente sistema de avaliação, analisaremos o que a doutrina e a jurisprudência brasileira entendem como justo valor e sua indenização, analisando seus elementos à luz dos princípios que informam a ordem urbanística e ambiental estabelecidas pela Constituição Federal de 1988 e de forma comparada com a legislação de outros países.

\subsection{Conceito de justa indenização}

Na justa indenização o que se busca é recompor o patrimônio daquele que foi expropriado. Assim, da mesma forma que não é justa a indenização irrisória, aquela incapaz de trazer a recomposição do patrimônio do expropriado, é também profundamente injusta a indenização excessiva, aquela extraordinariamente exorbitante, capaz de permitir enriquecimento ilícito à custa do erário, principalmente quando se trata de propriedades que nada produzem.

O direito fundamental da justa indenização aplica-se não só ao expropriado, mas também ao próprio expropriante, que não pode ser obrigado a submeter-se a uma indenização que extrapole os parâmetros de justiça e permita que o particular se locuplete indevidamente.

Analisando esse duplo significado da justiça do valor indenizatório nos processos de desapropriação, o Egrégio Tribunal Regional Federal da $3^{a}$ Região expressou o seguinte entendimento: 


\begin{abstract}
"O princípio constitucional da justa indenização deve ser interpretado como norma de proteção bipolar, ou de 'mão dupla'. A justiça da indenização compreende a garantia do cidadão contra a sanha expropriatória do Estado, protegido assim o direito fundamental à propriedade. No entanto, compreende também o princípio da justa indenização deverem o Estado e a coletividade serem protegidos contra o enriquecimento indevido às custas dos cofres públicos". (TRF $3^{\mathrm{a}}$ Região, $2^{\mathrm{a}}$ Turma, Rescisória n. 96.03.004927-1, rel. Desembargadora Sylvia Steiner, julgado em 4.12.96).
\end{abstract}

De outro lado, o Superior Tribunal de Justiça já decidiu que "Nenhuma decisão judicial pode amparar o enriquecimento sem causa. Toda a decisão há de ser justa." (STJ, 6 Turma, REsp n. 90.366-MG, rel. Min. Vicente Cernicchiaro, julgado em 11.6.96).

Com efeito, qualquer valor fixado mediante acordo judicial, ou imposto mediante sentença, que extrapole os limites do seu valor, afigura-se totalmente injusto e inconstitucional. Se menor do que os parâmetros descritos, a indenização é injusta, levando-se em consideração o prejuízo arcado pelo particular. Ao reverso, quando a indenização se consubstancia num enriquecimento indevido do particular em detrimento do patrimônio público, a referida eiva de inconstitucionalidade deve ser conhecida, resguardando, assim, o princípio, também constitucional, da igualdade das partes, seja no plano material, seja no plano jurídico formal. No binômio direito subjetivo fundamental versus interesse estatal, aquele prevalece. Por sua vez, na fórmula abuso de direito individual versus direito estatal, este há de ser aplicado.

$\mathrm{Na}$ atualidade, principalmente na década de 1990, a idéia de justo valor começou a fazer parte da pauta dos tribunais superiores em razão dos inúmeros pedidos de revisão de decisões que fixaram indenizações milionárias aos proprietários. Estas ações de revisão vêm sendo propostas ainda que já tenha transitado em julgado, ou seja, ainda que não sejam mais cabíveis recursos. 
No entanto, as discussões a respeito do valor justo de indenização ainda não incorporam conceitos e princípios de justiça social advindos do Estatuto da Cidade, sendo que a discussão se restringe à idéia de que valor justo é o mesmo que valor de mercado. Após pesquisas, verificamos que são raros os casos de manejo de conceitos como recuperação de mais-valia, função social da propriedade e justa distribuição dos benefícios e ônus decorrentes do processo de urbanização.

Assim, muito embora os tribunais debatam, com regularidade, a questão da justa indenização em virtude dos casos de superavaliações, é certo que não se investiga se os valores de indenização fixados nestas avaliações consideram os investimentos públicos ou privados que agregam valor ao imóvel, para a finalidade de recuperar as mais valias, o que sem dúvida é um dever também do Poder Judiciário em nome da realização de princípios constitucionais como o da moralidade pública e da justiça social, dentre outros.

\subsection{Entendimento da doutrina e da jurisprudência sobre indenização}

A concepção de indenização nos processos expropriatórios tem sua origem na Constituição Federal de 1988, que prevê em seu artigo 5ª inciso XXIV, a idéia de justa e prévia indenização. A justiça mencionada no artigo propõe que a indenização seja atribuída de acordo com a real perda do expropriado, ou seja, o equivalente ao que lhe foi tomado pelo expropriante (SALLES, 2006).

Não ignoramos que esse ideal de justiça da indenização nem sempre será atingido, porque os métodos de avaliação dos bens expropriados se ressentem - como tudo - das falhas humanas, além de também serem limitados. "Todavia, é o ideal que deve ser buscado com a máxima intensidade, pois a fixação de uma indenização justa é a única forma de atendimento ao preceito constitucional regulador da matéria" (SALLES, 2006, p. 511). 
Neste processo de apreciação da indenização, o Decreto-Lei ${ }^{\circ}$. 3.365, de 21 de junho de 1941, estabelece que cabe ao juiz a fixação deste valor. Em seu art. 27, determina alguns requisitos que devem ser adotados pelo magistrado para a apreciação. São eles: a estimação dos bens para efeitos fiscais; o preço de aquisição e interesse que o proprietário aufere dos bens expropriandos; à sua situação, estado de conservação e segurança; o valor venal dos bens da mesma espécie nos últimos cinco anos; e a valorização ou depreciação de área remanescente, pertencente ao desapropriado.

Segundo a doutrina brasileira o juiz não precisa ficar adstrito aos quesitos mencionados, pode ir além da fixação da indenização. O juiz firmará sua convicção livremente, pelo exame de todos os motivos que o processo lhe ofereça. "Considerará indispensavelmente esses que a lei indica, e, facultativamente, outros que se lhe afigurem merecedores de ponderação (...). Nessa elasticidade de apreciação, que lhe é deixada, está um dos grandes méritos da lei vigente”. (FAGUNDES, 1949, p.370).

Sem embargo, discordamos da doutrina no aspecto de que a elasticidade de apreciação que é deixada ao juiz é um grande mérito da legislação vigente. Em nossa opinião, como já assinalado em outras oportunidades nesse trabalho, a ausência de critérios mais objetivos, tanto para realização da avaliação do imóvel, como no caso da composição dos valores que integrarão a indenização para a finalidade de se fixar um valor justo de indenização, resulta em condenações muito discrepantes, fato que contribui para demora da solução judicial. $^{22}$

\footnotetext{
${ }^{22}$ A edição do jornal "Estado de São Paulo" de 8 de agosto de 1999, Silvio Bressan, em reportagem que tinha a chamada" Precatórios dão lucro até 50 vezes maior que a bolsa", deu início a uma ampla discussão sobre as "indenizações ambientais milionárias". Entre ouras coisas, escreveu o jornalista: "As ações indenizatórias nas desapropriações de terras pelo Estado para preservação ambiental são hoje o melhor investimento do mercado. Nada rendeu tanto, nos últimos anos, como o valor desses processos em São Paulo. Além da superavaliação das áreas, a correção pedida por ex-proprietários e dada pelo Judiciário fez dessas indenizações um negócio de rentabilidade até 50 vezes maior do que o melhor investimento do mercado. É o caso do maior precatório do país, relativo a uma área de 13,2 mil hectares de Ubatuba, Litoral Norte do Estado, para ser incorporada ao
} 
Os juízes não têm como fixar a indenização justa sem ponderar todas as questões que envolvam a valoração do solo urbano ou não urbano, as quais devem vir delineadas em legislação específica.

O primeiro quesito legal consiste na estimativa do valor dos bens para efeitos fiscais. Esta modalidade deve ser apreciada com ressalvas, uma vez que, o Fisco é deficiente na apreciação do valor venal. Com efeito, a falta de pessoal efetivamente habilitado para serviços dessa natureza, aliada à enorme quantidade de bens a serem avaliados por servidores em número diminuto, tem sido causa de inexatidão dos valores encontrados. Soma-se a estes fatores as manipulações de valores perpetradas por proprietários e funcionários públicos com o a finalidade de sonegar impostos (SALLES, 2006). Portanto, o juiz que utilize o critério da avaliação fiscal, deve estar atento a possíveis descompassos.

Outro quesito também mencionado na lei de desapropriações refere-se ao preço de aquisição do bem expropriando e o interesse que o proprietário aufere desse bem.

Normalmente, os negócios imobiliários são realizados por meio de escritura pública, estando isentos de tal exigência apenas os negócios de valor inferior a 30 salários mínimos. Durante um longo período, os impostos que recaiam sobre o chamado lucro imobiliário eram tão elevados que, os negócios eram lavrados com base em valores inferiores aos efetivamente pagos. Contudo, ainda que tais impostos estejam menores, tal situação ainda ocorre corriqueiramente, o que também dificulta a utilização de tal critério para a fixação da indenização.

Parque Estadual da Serra do Mar. A área, pertencente à administradora JNL Ltda., valia, em agosto de 1988, US\$ 2.4 milhões, conforme relatório técnico da Secretaria do Meio Ambiente. Se a JNL tivesse vendido essa área pelo valor de mercado e aplicado na época todo esse dinheiro na bolsa de valores, o melhor investimento, nesses 11 anos, teria hoje $\mathrm{R}$ \$ 18,5 milhões. Como preferiu acionar o governo, a empresa já é credora de uma indenização de $\mathrm{R} \$ 1,1$ bilhão." 
Sobre tal requisito, o juiz deverá ter sempre em vista as falhas que este fator de indenização pode conter, sob pena de estabelecer indenização inadequada e em desconformidade com o principio constitucional do justo ressarcimento ao expropriado. Não se perca de vista, ainda, que a aquisição do bem pelo expropriado pode ter-se dado dez, quinze, vinte anos antes da desapropriação e, em um país que passou por períodos de inflação, como o nosso, é evidente que o custo histórico do bem há de ser tanto mais afastado do valor atual quantos sejam os anos decorridos desde a data de aquisição (SALLES, 2006). O que se verifica nestes casos é uma enorme discrepância entre os valores de mercado, e os valores declarados na escritura de compra e venda.

Ao se tratar dos valores para efeitos fiscais, não cabe ao juiz que avalia o bem expropriado analisar eventual fraude ao Fisco, haja vista que isto recairá sobre a lei tributária. Se o ressarcimento devido ao expropriado deve corresponder à quantia que preencha, em seu patrimônio, o vazio deixado pelo desfalque sofrido com a desapropriação, é a evidência cristalina a valia desse elemento no momento em que o juiz passa a aplicar seu intelecto no difícil e árduo trabalho de estabelecer as coordenadas que irá levá-lo à fixação do justo preço (SALLES, 2006).

Como exemplo, podemos trazer a situação de um imóvel que integre a exploração de uma atividade econômica, e o aviamento da empresa. Neste caso, devem ser considerados como valores indenizáveis aqueles decorrentes do estabelecimento comercial de empresas em plena atividade, uma vez que o empresário deverá ter gastos com a recomposição de sua atividade. Este exemplo constitui uma clara expressão de casos em que se deve considerar o 
valor auferido pelo desapropriando para fins de indenização (RDA 98/172, RDA 121/278, RDA 109/140, RT 197/173, RT 317/147) ${ }^{23}$.

Contudo, não é pacífica a idéia de incorporação dos lucros cessantes na indenização por motivo de desapropriação, conforme menciona a RDA 102/192 que introduz a corrente "não cabe o pagamento de lucros cessantes no computo da indenização devida ao expropriado"

Em sentido contrário, Salles (2006, p.523):

\begin{abstract}
"Perfilhamos, entretanto, o ponto de vista dos que entendem ser devida a indenização por lucros cessantes.

Com efeito, a indenização a que faz jus o expropriado, para ser justa, deve recompor seu patrimônio com quantia que corresponda exatamente ao desfalque produzido pela desapropriação. Destarte, a simples indenização do bem expropriado, desacompanhada das perdas e danos sofridos pelo proprietário (incluídos nestes os danos emergentes e os lucros cessantes), tornaria insuficiente o ressarcimento, representando tal fato visível descumprimento da norma constitucional que determina seja justa indenização (art. 5, XXIV da CF).
\end{abstract}

Neste ponto é importante fazer a distinção entre o valor de afeição do valor de conveniência. O primeiro consiste no valor declarado unilateralmente e subjetivamente pelo proprietário do bem objeto da ação de desapropriação, valor este baseado estritamente em seu interesse, não podendo ser comprovado economicamente. Já o valor de conveniência, pode ser avaliado economicamente, sendo objetivamente auferido pelo proprietário.

O entendimento que é mais aceitável é o de que não se compõem fatores de afeição ou puramente subjetivos no valor da indenização, tal como ocorre na esfera privada (art.1.543 do Código Civil). E não se levam em conta tais fatores porque o valor efetivo diz somente respeito ao uso peculiar da coisa que lhe faz o titular. É um fator meramente pessoal,

\footnotetext{
${ }^{23}$ Para a doutrina dano emergente "é aquilo que se perdeu", enquanto que os lucro cessante "é aquilo que se deixou de lucrar".
} 
e, evidentemente, não tem expressão quando se considera a propriedade unicamente pela sua faceta objetiva de poder trocá-la por outra equivalente em dinheiro.

Salles (2006, p.526) esclarece sobre a matéria: "Para nós, portanto, sem embargo do respeitável entendimento defendido pela mais alta Corte do Estado de São Paulo, manifestado no acórdão a que nos referimos (RDA 75/211), o valor estimativo ou de afeição não é indenizável nas desapropriações”.

Outra questão a se ressaltar é a que se refere ao valor histórico do bem para fins de indenização. Não há posição unificada quanto à questão, Fagundes (1949, p.346), por exemplo, esposa o entendimento de que não há possibilidade de separar o valor histórico do próprio valor estimativo. Já autores como Salles (2006, p.526) defendem a seguinte posição:

\footnotetext{
"Entendemos que o valor histórico acrescenta ao bem uma valia maior do que a que teria se não ligasse à Historia. Ora, essa mais-valia, decorrente do elemento histórico, é apreciável e avaliável economicamente, razão por que nos parece deva ser levada em conta como componente da indenização devida ao expropriado. (...) Pensamos, pois, que o valor histórico, ao contrário do valor de afeição, pode ser perfeitamente estimado, razão pela qual entendemos deva ser considerado elemento integrante da indenização no feito expropriatório".
}

Há que se considerar para utilização deste quesito a questão da inflação, que consiste na perda do valor real da moeda e bens.

A partir de 1964, com a instituição dos índices de correção monetária, baixados pelo Governo Federal e por outras instituições se tornou possível a atualização a contar de um determinado momento, dos valores de aquisições realizadas anos antes. Esse procedimento tem sido, aliás, utilizado com muita freqüência pelos peritos judiciais, quando, no uso do método comparativo, confrontam os valores de escrituras de compra e venda de imóveis relativas a transações realizadas três, quatro ou cinco anos antes. 
Não obstante, apesar do advento desse instrumento de atualização de valores, com base em índices baixados pelo órgão federal competente, é entendimento corrente, inclusive junto ao Poder Judiciário, que o processo inflacionário vicia e prejudica os dados constantes do laudo de avaliação, reduzindo a eficácia que teria se aplicado em época de estabilidade monetária.

No que tange à expressão “bens da mesma espécie”, para Fagundes (1949, p.530) corresponde a bens de igual destinação econômica, não bastando a equivalência aparente ou natural; há de ser real, ou seja, de mesma aplicação econômica (FAGUNDES, 1949, p. 530).

Em oposição a tal pensamento há o entendimento de que o sentido da expressão "espécie" não se encontra respaldado na destinação econômica dada ao bem, mas sim o intuito com que foi construído. Para que os peritos possam avaliar o valor venal desses bens, normalmente se usa o método comparativo, elucidado pela $3^{\text {a }}$ Câmara Civil do E. Tribunal de Justiça do Estado de São Paulo: "nas avaliações, é o mais simples, pratico, seguro e exato, para determinar o justo preço, ou seja, o valor real da coisa desapropriada” (SALLES, 2006, p. 532).

Contudo, tal método muitas vezes é questionado quanto à sua eficácia. Para citarmos um exemplo, acórdão proferido pela $1^{\text {a }}$ Câmara Civil do Tribunal de Justiça de São Paulo, teve sua efetividade contestada pelo Desembargador Euclides Custodio da Silveira, relator do processo, que afirmou:

\footnotetext{
"Por si só, o método comparativo, frequentemente adotado nas avaliações de terrenos, nem sempre satisfaz, tais são, entre outras razões, as particularidades de cada caso concreto, das diversas transações consideradas e as oscilações dos valores imobiliários em períodos de tempo bem curtos, nos últimos anos. Elemento informativo dos mais recomendáveis, para se calcularem os valores dos terrenos das zonas urbanas e suburbana da Capital, é o Dec. Municipal 2.328, de 03.12.1953, que aprovou as plantas genéricas de valores de terrenos, para efeito de lançamentos fiscais". (RDA 40/291)
} 
Sobre os mais variados métodos de avaliação das desapropriações, Salles (2006, p. 536) conclui:

\begin{abstract}
"Atente-se, finalmente, para esta verdade fundamental: seja qual for o método de avaliação empregado, há de se ter em vista, sempre, a Alçada de São Paulo, publicado na RDA 103/200, no sentido de que “...Nas avaliações em feitos desapropriatórios, o perito não se olvida do seu fundamental objetivo, que é o de apurar montante condizente com o valor de mercado, a fim de que se possa conceder ao expropriado a quantia necessária e suficiente para que com ela se adquira ou se edifique imóvel equivalente".
\end{abstract}

Por fim, um dos temas de grande importância ao tratarmos de desapropriações parciais é o caso de desvalorização ou supervalorização das áreas remanescentes em decorrência da expropriação.

Em algumas situações, em função da expropriação parcial o imóvel acaba sofrendo uma repentina valorização devido às obras públicas ali realizadas.

Uma parcela da doutrina entende como indevida esta valorização, uma vez que o proprietário não deu causa à mesma. Diante deste pensamento, surgem algumas hipóteses para suprir o beneficio indevido, sendo elas: a) a cobrança de contribuições de melhoria; b) a desapropriação por zona (também chamada extensiva), recaindo sobre terrenos extraordinariamente valorizados em consequiência das obras ou serviços realizados; c) a compensação da mais-valia do remanescente com a indenização a ser paga ao expropriado.

Para a doutrina existem duas espécies de valorização: a) a especial ou imediata, em que a valorização deverá ser descontada da indenização, por lhe trazer benefícios diretos, e; b) a geral, em que a valorização não deve ser descontada, uma vez que os benefícios envolvidos atingem a todos, cabendo, portanto, a contribuição de melhoria para arcar com as despesas. (RT 341/194). 
Em grande parte das situações a valorização ocorrida é geral, ou seja, traz benefícios tanto aos antigos proprietários dos bens expropriados como os demais imóveis da região. Devido a essa valorização ampla da região, o Supremo Tribunal Federal pauta seu entendimento na impossibilidade de desconto na indenização, e adota a necessidade da cobrança de contribuições de melhoria a todos os beneficiários da valorização.

O desconto no valor da indenização só deve ser utilizado quando a valorização seja imediata ou especial situação que não ocorre com tanta freqüência. A lei, por seu turno, silencia em tais casos como efetuar o cálculo do quantum indenizatório, e, devido a essa omissão legal doutrinadores posicionam-se contrários à absorção integral do quantum indenizatório pela mais-valia criada; apenas a incorporação parcial. Tais autores defendem que somente é possível tal desconto mediante expressa previsão legal, para que o princípio constitucional que garante a prévia e justa indenização em dinheiro não fosse agredido. "É impossível, porém, definir um limite para essa compensação parcial. O juiz, em cada caso, consideradas as suas condições peculiares e o montante dos dois valores, arbitrará a maisvalia na base que se lhe afigure razoável" (FAGUNDES, 1949, p.358).

Há casos de depreciação da área remanescente, que podem ocorrer em função de uma série de fatores, como os introduzidos por Salles (2006, p.536). São eles: “a) a redução da área restante a dimensão tal que impeça construção sobre a mesma; b) localização a margem de via publica (resultante da obra executada pelo expropriante) excessivamente barulhenta, contra-indicando a edificação de prédio residencial sobre o remanescente; c) seccionamento da propriedade agrícola, ficando uma pequena área separada da parte principal da propriedade pela estrada de rodagem construída, inexistindo na gleba menor as aguadas necessárias ao gado e os mananciais indispensáveis a rega das plantações, etc." 
Já nos casos em que a desapropriação acarreta uma desvalorização do imóvel remanescente, existem também algumas medidas que podem ser adotadas. São elas: “a) expropriação do remanescente; b) indenização das perdas e danos; c) inclusão da quantia correspondente à desvalorização do remanescente na indenização devida ao expropriado" (SALLES, 2006, p.537).

Nos casos de desvalorização caberá sim o ressarcimento no quantum indenizatório, antecipando uma possível ação judicial sobre a mesma questão. Existem situações em que a desvalorização do imóvel é tão expressiva, que a sua utilização torna-se inviável. A jurisprudência tem se posicionado no sentido de que se há desvalorização que impossibilite a utilização do imóvel para o fim que se destina, o quantum indenizatório deverá ser calculado na integralidade do bem, incluindo seu remanescente (RDA119/310). O tema não se encontra devidamente sedimentado, havendo expressivas correntes divergentes na doutrina e jurisprudência.

Em conclusão, vale transcrever um pequeno fragmento do despacho publicado na RT 489/257 traduz com clareza a questão supra mencionada:

\footnotetext{
"Ora, o conceito de justa indenização, nas expropriatórias parciais, envolve sempre o cuidadoso exame da situação das áreas remanescentes: por vezes o remanescente se valoriza, atuando na fixação do quantum da indenização, em beneficio do expropriante; por vezes torna-se inaproveitável, impondo a extensão da desapropriação ao remanescente; por vezes sofre desvalorização que justifica a concessão de uma verba que se tenha adequada para a recomposição do patrimônio do expropriado".
}

\subsection{Correlação entre justo valor e princípios de direito urbanístico}

Após analisarmos como os dispositivos a respeito da indenização vêm sendo tratados pela doutrina e pela justiça brasileira, passo a transcorrer sobre a correlação entre justo preço e princípios de direito urbanístico. 
Como já salientamos nesse trabalho, a legislação utilizada em tema de desapropriação é anterior à Constituição Federal de 1988 e ao próprio Estatuto da Cidade, motivo pelo qual a desapropriação tem tratamento muito segmentado relativamente aos novos pilares do direito urbanístico brasileiro.

A idéia de recuperação de mais valias e a de justa distribuição dos benefícios e ônus decorrentes do processo de urbanização são princípios inseridos expressamente no ordenamento brasileiro com o advento do Estatuto da Cidade $^{24}$ e a legislação a respeito de desapropriação, Decreto-Lei $n^{\circ}$. 3.365, de 21 de junho de 1941 e Lei ${ }^{\circ}$. 4.132, de 10 de setembro de 1962, embora discipline a valorização advinda com a desapropriação, não incorporaram esses princípios. ${ }^{25}$

A lei de desapropriação brasileira não estabeleceu critérios a respeito da avaliação para fins de indenização. Contudo, em momentos distintos, estabeleceu o que é valor real de indenização para a desapropriação que descumpre a função social da propriedade e o que é justa indenização para fins de desapropriação de reforma agrária.

O Estatuto da Cidade, Lei $\mathrm{n}^{\circ}$. 10257, de 10 de Julho de 2001, ao disciplinar a desapropriação para os imóveis que não cumprem a função social estabelecida nos planos

\footnotetext{
${ }^{24}$ O Estatuto da Cidade da Cidade, Lei ${ }^{\circ}$. 10257, de 10 de Julho de 2001 tratou expressamente destes princípios nos seguintes termos:

"Art. $2^{\mathrm{O}}$. A política urbana tem por objetivo ordenar o pleno desenvolvimento das funções sociais da cidade e da propriedade urbana, mediante as seguintes diretrizes gerais:

(...)

IX - justa distribuição dos benefícios e ônus decorrentes do processo de urbanização;

(...)

XI - recuperação dos investimentos do Poder Público de que tenha resultado a valorização de imóveis urbanos;

${ }^{25}$ A respeito da recuperação da valorização ocorrida com a própria desapropriação, o Decreto-Lei $n^{\circ}$. 3.365, de 21 de junho de 1941, assim disciplina a matéria:

"Art. 27. O juiz indicará na sentença os fatos que motivaram o seu convencimento e deverá atender, especialmente, à estimação dos bens para efeitos fiscais; ao preço de aquisição e interesse que deles aufere o proprietário; à sua situação, estado de conservação e segurança; ao valor venal dos da mesma espécie, nos últimos cinco anos, e à valorização ou depreciação de área remanescente, pertencente ao réu."
} 
diretores, estabelece que a indenização do imóvel seja o seu valor real, definindo-o da seguinte forma:

\footnotetext{
"Art. $8^{\circ}$. Decorridos cinco anos de cobrança do IPTU progressivo sem que o proprietário tenha cumprido a obrigação de parcelamento, edificação ou utilização, o Município poderá proceder à desapropriação do imóvel, com pagamento em títulos da dívida pública.

$\S 1^{\circ}$ Os títulos da dívida pública terão prévia aprovação pelo Senado Federal e serão resgatados no prazo de até dez anos, em prestações anuais, iguais e sucessivas, assegurados o valor real da indenização e os juros legais de seis por cento ao ano.

$\S 2^{\circ} \mathrm{O}$ valor real da indenização:

I - refletirá o valor da base de cálculo do IPTU, descontado o montante incorporado em função de obras realizadas pelo Poder Público na área onde o mesmo se localiza após a notificação de que trata o $\S 2^{\underline{0}}$ do art. $5^{\circ}$ desta Lei;

II - não computará expectativas de ganhos, lucros cessantes e juros compensatórios."
}

Tendo em vista o tratamento dado para o termo "valor real", depreende-se logo que não se trata da mesma idéia de justo preço ou justo valor tratada pela doutrina e pela jurisprudência brasileiras para as desapropriações por utilidade pública ou interesse social, mesmo porque a definição de valor real estabelecida pelo Estatuto da Cidade tem por objetivo a indenização do proprietário que não cumpre a função social da propriedade, assim, nesta indenização, por expresso comando legal, não serão computados nem lucros cessantes nem juros compensatórios.

Nesta esteira, a lei denomina valor real o justo preço da desapropriação-sanção, cujos limites são mais reduzidos do que a indenização baseada na idéia do justo preço da desapropriação por utilidade pública. 
Ainda, a legislação brasileira tratou de estabelecer o que é justo preço para as desapropriações para reforma agrária, cujo objeto é o imóvel rural que não cumpra função social rural ${ }^{26}$, cujos termos são:

“Lei n’. 8.629, de 25 de fevereiro de 1993

Art. 12. Considera-se justa a indenização que reflita o preço atual de mercado do imóvel em sua totalidade, aí incluídas as terras e acessões naturais, matas e florestas e as benfeitorias indenizáveis, observados os seguintes aspectos:

(“...)”

Com base na legislação exposta, a idéia de justo preço tem correlação com o princípio da função social da propriedade, tanto no caso da desapropriação urbana, como na rural. Na urbana, a função social da propriedade é aquela delineada pelos planos diretores dos Municípios, na rural a descrita pela Lei n ${ }^{\circ} .8 .629$, de 25 de fevereiro de 1993.

Para as desapropriações por utilidade pública ou interesse social, a lei nada estabelece a respeito da observância de princípios urbanísticos ou ambientais na fixação da justa indenização. Nesse ponto, é importante que a lei discipline os critérios de avaliação tendo em vista o que deve ser entendido como justo preço para essas espécies de desapropriação a fim de propiciar uma maior segurança às partes envolvidas no processo de desapropriação.

Muito embora o Brasil tenha suas características, salientamos que a legislação estrangeira tem uma disciplina mais rigorosa para a questão.

Transcrevemos os artigos que tratam do tema no Código das Expropriações de Portugal, Lei 168/99:

\footnotetext{
${ }^{26}$ Sobre o conteúdo de função social da propriedade rural, ver art. $9^{\circ}$. da Lei ${ }^{\circ}$. 8.629, de 25 de fevereiro de 1993.
} 
“TÍTULOIII

Do conteúdo da indemnização

Artigo 23. ${ }^{\circ}$

Justa indemnização

1 - A justa indemnização não visa compensar o benefício alcançado pela entidade expropriante, mas ressarcir o prejuízo que para o expropriado advém da expropriação, correspondente ao valor real e corrente do bem de acordo com o seu destino efectivo ou possível numa utilização económica normal, à data da publicação da declaração de utilidade pública, tendo em consideração as circunstâncias e condições de facto existentes naquela data".

E ainda, a lei espanhola sobre expropriação:

“Lei 6/1998, sobre règim del sòl i regles de valoració

Artículo 36. Procedimiento de determinación del justiprecio

El justiprecio de los bienes y derechos expropiados se determinará conforme a lo establecido en el título III de la presente Ley, mediante expediente individualizado o por el procedimiento de tasación conjunta.

\section{TÍTULO III}

\section{Valoraciones}

Artículo 23. Aplicación general de las reglas de valoración

A los efectos de expropiación, las valoraciones de suelo se efectuarán con arreglo a los criterios establecidos en la presente Ley, cualquiera que sea la finalidad que la motive y la legislación, urbanística o de otro carácter, que la legitime”.

Sabemos que a lei não obstaculizará as discussões a respeito da justa indenização ${ }^{27}$, mas a ausência de regramento para as questões de avaliação e justa indenização da lei brasileira é um componente que permite distorções muito acentuadas na fixação do valor final das indenizações.

\footnotetext{
${ }^{27}$ Em Portugal, mesmo com um a legislação bem eficiente em tema de expropriação, há grande discussão sobre o justo preço. Neste sentido, podemos verificar a dimensão das controvérsias em seminário promovido sobre a Avaliação do Código das Expropriações, em 25/09/2003, pela Associação Nacional de Municípios Portugueses, em exposição de António Pereira da Costa:

“ A maior discussão ligada à fixação do justo preço estava e está na distinção entre 'solos aptos para construção" "e "solos para outros fỉns", sendo estes determinados por via residual, depois de definidos os primeiros".
} 


\subsection{Função social da propriedade e justo valor}

A Constituição Federal de 1988, por um lado, garante o direito de propriedade e, por outro, afirma que a propriedade atenderá a função social (art. $5^{\circ}$, XXIII e XXII). “Conclui-se que a propriedade não é função $\operatorname{social}^{28}$, mas um direito que tem uma função social" (PINTO, 2005, p. 185). Assim também ocorre na Constituição de outros países. ${ }^{29}$

Com efeito, em tema de desapropriação, a idéia de justo preço, em toda sua extensão, no Brasil, só tem aplicação para as desapropriações que cumpram sua função social, que, em área urbana, deve vir definida nos planos diretores municipais. Aquela propriedade que não cumpre sua função social será penalizada com a desapropriação, cujo preço será pago em títulos da dívida pública, descontados lucros cessantes, juros compensatórios e as mais valias incorporadas ao valor do imóvel.

\footnotetext{
${ }^{28}$ Em sentido contrário, ver o texto abaixo da Constituição da Colômbia.

27 Propriedade e função social em outras Constituições:
}

Bolivia:

“Artículo 7.- Toda persona tiene los siguientes derechos fundamentales, conforme a las leyes que reglamenten su ejercicio:

j. A la propiedad privada, individual o colectivamente, siempre que cumpla una función social”;

Chile:

“Artículo 19.- La Constitución asegura a todas las personas:

24. El derecho de propiedad en sus diversas especies sobre toda clase de bienes corporales o incorporales.

Sólo la ley puede establecer el modo de adquirir la propiedad, de usar, gozar y disponer de ella y las limitaciones y obligaciones que deriven de su función social. Esta comprende cuanto exijan los intereses generales de la Nación, la seguridad nacional, la utilidad y la salubridad públicas y la conservación del patrimonio ambiental."

\section{Colombia:}

“Artículo 58. - Se garantizan la propiedad privada y los demás derechos adquiridos con arreglo a las leyes civiles, los cuales no pueden ser desconocidos ni vulnerados por leyes posteriores. Cuando de la aplicación de una ley expedida por motivos de utilidad pública o interés social, resultaren en conflicto los derechos de los particulares con la necesidad por ella reconocida, el interés privado deberá ceder al interés público o social. La propiedad es una función social que implica obligaciones. Como tal, le es inherente una función ecológica" Equador:

"Artículo 30.- La propiedad, en cualquiera de sus formas y mientras cumpla su función social, constituye un derecho que el Estado reconocerá y garantizará para la organización de la economía".

Honduras:

“Artículo 103.- El Estado reconoce, fomenta y garantiza la existencia de la propiedad privada en su más amplio concepto de función social y sin mas limitaciones que aquellas que por motivos de necesidad o de interés publico establezca la ley".

Panamá:

"Artículo 45.- La propiedad privada implica obligación para su dueño por razón de la función social que debe llenar". 
Questão importante é saber se toda propriedade objeto de desapropriação por utilidade pública ou interesse social atende à função social definida no plano diretor, para a finalidade de se aplicar as disposições do Estatuto da Cidade relativamente à indenização. Suponhamos o caso de ser necessário desapropriar área para construção de equipamentos públicos e, apesar da Administração Pública não ter iniciado o procedimento para obrigar o proprietário a utilizar o solo adequadamente, sob pena de desapropriação, resta configurado que o proprietário não está cumprindo a função social da propriedade.

Na ausência de lei que discipline o assunto, entendemos que a desapropriação por descumprimento da função social da propriedade tem caráter de penalidade e não seria compatível com o nosso Estado de Direito estender a penalidade para situações que não observe o procedimento para a desapropriação-sanção, conforme art. $8^{\circ}$. do Estatuto da Cidade, norma que possui caráter geral e deve ser seguida pelos Municípios. Se o Município não observa referido procedimento, mormente se não planejou a desapropriação da área, o proprietário do imóvel não pode ser penalizado com a disciplina das normas aplicáveis à desapropriação por descumprimento da função social da propriedade.

Outra situação que pode ocorrer é a de como considerar se a propriedade não está cumprindo a sua função social quando o Município em que está inserido o imóvel não possui plano diretor.

Entendemos que a norma constitucional que impõe à propriedade o cumprimento de função social tem eficácia limitada ${ }^{30}$, ou seja, embora tenha eficácia jurídica, sua eficácia no plano fático só ocorrerá com a edição de outras normas, no caso de áreas urbanas, pela lei que institui o plano diretor.

\footnotetext{
${ }^{30}$ Sobre o grau de eficácia das normas constitucionais ver José Afonso da Silva, em seu livro Aplicabilidade das Normas Constitucionais.
} 
Embora o Judiciário, na ausência da edição de normas que complementem as normas de eficácia limitada, possa atribuir eficácia fática a um determinado caso concreto, no caso específico da ação de desapropriação, haveria dificuldade em suprir a lei e atribuir o que seria função social da propriedade ao imóvel objeto da desapropriação. Ademais a definição de função social da propriedade urbana é tarefa tipicamente executiva e exige planejamento técnico, o que impossibilita uma decisão judicial nesse sentido.

A solução possível também deveria vir estabelecida por lei, em que se disciplinassem critérios para se aferir o descumprimento da função social da propriedade urbana para os Municípios que não possuam plano diretor.

De qualquer modo, pela estrutura federativa do Brasil, é incumbência do Município atribuir função social à propriedade urbana, conforme art. 182 da Constituição Federal de 1988 e, mesmo que uma lei federal viesse a estabelecer critérios para os Municípios que não possuam plano diretor, essa lei teria caráter geral, necessariamente prescindindo de lei municipal para lhe complementar.

Do mesmo modo, é a disciplina em outros países, conforme podemos verificar na Lei de desenvolvimento territorial colombiana. Lei 388 de 1997:

\section{“CAPITULO VI}

\section{Desarrollo y construcción prioritaria}

Artículo 52. Desarrollo y construcción prioritaria. A partir de la fecha de vigencia de esta ley, habrá lugar a la iniciación del proceso de enajenación forzosa en pública subasta, por incumplimiento de la función social de la propiedad sobre:

1. Los terrenos localizados en suelo de expansión, de propiedad pública o privada, declarados como de desarrollo prioritario, que no se urbanicen dentro de los tres (3) años siguientes a su declaratoria. (...)

Parágrafo. La declaratoria de desarrollo o construcción prioritaria estará contenida en el programa de ejecución, de conformidad con las estrategias, directrices y parámetros previstos en el plan de ordenamiento territorial, de acuerdo con los 
objetivos establecidos en el plan para el logro de su cumplimiento. En todo caso esta declaratoria podrá preverse directamente en el contenido del plan de ordenamiento."

Embora referida lei estabeleça critérios para a expropriação por descumprimento da função social da propriedade, é o governo local que estabelecerá quais são as zonas de expansão prioritária.

\subsection{Recuperação das mais valias originadas por intervenção do Poder Público e justo valor}

A presente pesquisa procurou identificar nos procedimentos adotados pela Justiça de São Paulo quanto à recuperação das mais-valias oriundas de investimentos públicos nas áreas desapropriadas. Neste aspecto, entendemos oportuno, relatar, o que vem sendo entendido, neste tema pelos tribunais superiores, nos raros casos que a questão é submetida ao Superior Tribunal de Justiça. ${ }^{31}$

Segundo Recurso Especial no 795.446 de 01.02.2007 ${ }^{32}$, na desapropriação, direta ou indireta, quando há valorização da área remanescente não desapropriada em decorrência de obra ou serviço público, dispõe o Estado de três instrumentos legais para evitar que a mais valia, decorrente da iniciativa estatal, locuplete sem justa causa o patrimônio de um ou de poucos: a desapropriação por zona ou extensiva, a cobrança de contribuição de melhoria e o abatimento proporcional, na indenização a ser paga, da valorização trazida ao imóvel.

Para a referida decisão, no caso de ocorrer valorizações gerais ordinárias o Poder Público dispõe da contribuição de melhoria, para as valorizações gerais extraordinárias a desapropriação por zona, prevista no art. $4^{\circ}$ do Decreto-Lei n ${ }^{\circ}$. 3.365, de 21 de junho de 1941,

\footnotetext{
${ }^{31}$ No Brasil, há uma divisão de competências dos Tribunais Superiores. O STF - Supremo Tribunal Federal analisa questões com interface com artigos da Constituição Federal. O STJ - Superior Tribunal de Justiça analisa as questões que possuam interface com as leis federais.

32 Julgamento perante o Superior Tribunal de Justiça.
} 
pois a revenda futura dos imóveis valorizados recuperará a mais valia e permitirá socializar o benefício a toda a coletividade.

No entanto, tratando-se de valorização específica, poderá o Estado abater do valor a ser indenizado a valorização experimentada pela área remanescente não desapropriada, nos termos do artigo 27 do Decreto-Lei n .3 .365 , de 21 de junho de 1941.

Como exemplo, nesse caso em julgamento, entendeu-se que a valorização imobiliária advinda com a construção de uma rodovia estadual é genérica atingindo em patamares semelhantes todos os imóveis vizinhos à rodovia sendo indevida a recuperação da mais valia pela forma de abatimento no preço da indenização, mas sim pela utilização da instituição do tributo da contribuição de melhoria.

Por oportuno também cabe consignar o entendimento de que a valorização imobiliária decorrente de decisões do Poder Público, como no caso das mudanças de uso do solo, não devem ser indenizadas nos processos de desapropriação, sob pena de se infringir o preceito legal da proibição do enriquecimento sem causa, conforme dispõe o Código Civil em seus arts. 885 e seguintes ${ }^{33}$. O que se sustenta é que o particular não pode ser indenizado por uma ação exclusiva do Estado, pois ela não deriva de nenhum investimento direto do particular (RABELLO, 2002).

\footnotetext{
${ }^{33}$ Artigos do Código Civil Brasileiro que tratam da proibição do enriquecimento sem causa:

"Art. 884. Aquele que, sem justa causa, se enriquecer à custa de outrem, será obrigado a restituir o indevidamente auferido, feita a atualização dos valores monetários. Parágrafo único. Se o enriquecimento tiver por objeto coisa determinada, quem a recebeu é obrigado a restituí-la, e, se a coisa não mais subsistir, a restituição se fará pelo valor do bem na época em que foi exigido.

Art. 885. A restituição é devida, não só quando não tenha havido causa que justifique o enriquecimento, mas também se esta deixou de existir.

Art. 886. Não caberá a restituição por enriquecimento, se a lei conferir ao lesado outros meios para se ressarcir do prejuízo sofrido."
} 
Sabemos que politicamente há muito desgaste para um governante instituir a contribuição de melhoria decorrente da valorização de determinada obra, principalmente porque no Brasil a cobrança de tributos ordinários já é muito elevada, mas o instrumento tem contornos mais avançados em outros países.

Encontramos na legislação colombiana disposições semelhantes sobre a recuperação de mais valias, em procedimento de desapropriação:

"Ley 388/1997:

Artículo 61. Modificaciones al procedimiento de enajenación voluntaria. Se introducen las siguientes modificaciones al procedimiento de enajenación voluntaria regulado por la Ley $9^{\text {a }}$ de 1989:

$(\ldots)$

Parágrafo $1^{\circ}$. Al valor comercial al que se refiere el presente artículo, se le descontará el monto correspondiente a la plusvalía o mayor valor generado por el anuncio del proyecto u obra que constituye el motivo de utilidad pública para la adquisición, salvo el caso en que el propietario hubiere pagado la participación en plusvalía o la contribución de valorización, según sea del caso."

Contudo, a citada lei colombiana também estabelece outro modo de se capturar as

mais valias oriundas de ações estatais, mesmo fora de procedimentos de desapropriação.

\section{“Participación en la plusvalía}

Artículo 73. Noción. De conformidad con lo dispuesto por el artículo 82 de la Constitución Política, las acciones urbanísticas que regulan la utilización del suelo y del espacio aéreo urbano incrementando su aprovechamiento, generan beneficios que dan derecho a las entidades públicas a participar en las plusvalías resultantes de dichas acciones. Esta participación se destinará a la defensa y fomento del interés común a través de acciones y operaciones encaminadas a distribuir y sufragar equitativamente los costos del desarrollo urbano, así como al mejoramiento del espacio público y, en general, de la calidad urbanística del territorio municipal o distrital.

\section{(...)}

Artículo 74. Hechos generadores. Constituyen hechos generadores de la participación en la plusvalía de que trata el artículo anterior, las decisiones administrativas que configuran acciones urbanísticas según lo establecido en el artículo $8^{\circ}$ de esta ley, y que autorizan específicamente ya sea a destinar el inmueble a un uso más rentable, o bien incrementar el aprovechamiento del suelo permitiendo una mayor área edificada, de acuerdo con lo que se estatuya formalmente en el 
respectivo Plan de Ordenamiento o en los instrumentos que lo desarrollen. Son hechos generadores los siguientes:

1. La incorporación de suelo rural a suelo de expansión urbana o la consideración de parte del suelo rural como suburbano.

2. El establecimiento o modificación del régimen o la zonificación de usos del suelo.

3. La autorización de un mayor aprovechamiento del suelo en edificación, bien sea elevando el índice de ocupación o el índice de construcción, o ambos a la vez.”

A participação ${ }^{34}$ nas mais valias é uma forma do Estado captar, em parte, o incremento do valor dos imóveis que são beneficiados por ações estatais em âmbito territorial. Tem como objetivo financiar os custos com infra-estrutura urbana. Essa participação é definida como uma espécie de tributo, embora se constitua como gravame que não se confunde com imposto ${ }^{35}$. Os fatos geradores desse tributo são o incremento em razão da mudança de solo rural para o urbano, o incremento advindo com a mudança de índices construtivos $^{36}$ e a execução de obras públicas que gerem externalidades positivas para o imóvel.

$\mathrm{O}$ art. 79 da citada lei se estabelece que os proprietários que incidirem nestes fatos geradores pagarão entre $30 \%$ e $50 \%$ do valor incrementado, de acordo com as decisões das autoridades municipais. Este pagamento é devido quando o incremento no valor se comprova de modo efetivo: quando se efetua uma transação imobiliária, quando se solicita uma licença de urbanização ou de construção, quando a mudança de uso do imóvel. Contudo, a Colômbia tem enfrentado dificuldades na aplicação do instrumento, que exige duas avaliações: uma prévia à ação urbanística e outra posterior a ela, pois a alíquota incidirá sobre essa diferença.

\footnotetext{
34 Para uma maior compreensão do tema, ver FURTADO, Fernanda. Recuperação de mais-valias fundiárias urbanas na América Latina: debilidade na implantação, ambigüidades na interpretação. 1999 - Tese de doutorado, Faculdade de Arquitetura e Urbanismo, Universidade de São Paulo, São Paulo, 1999.

35 Tradicionalmente são espécies de tributo: impostos, taxas e contribuições de melhoria. Mais recentemente se criou uma nova categoria que são as contribuições previdenciárias. A participação nas mais valias é uma nova modalidade de tributo introduzida pela Lei 388 colombiana.

${ }^{36}$ Equivalência com o instrumento da outorga onerosa (solo criado) previsto no Estatuto da Cidade da Cidade.
} 
Anotamos que o instrumento de participação nas mais valias não exclui o instrumento da contribuição de melhoria. É a autoridade municipal que decidirá em que circunstância o instrumento será utilizado, pois a cobrança da participação nas mais valias tem um custo e talvez não seja conveniente instituí-la (JARAMILLO, 2001) .

Trata-se de um instrumento recente e, embora de difícil aplicação, a experiência de sua cobrança poderá influenciar outros países de forma positiva.

\subsection{Conclusões}

Tanto a legislação brasileira como a legislação estrangeira, revelam que há intersecção entre o estabelecimento do justo preço em indenização e princípios de direito urbanístico.

Contudo, a legislação brasileira tendo em vista as dificuldades práticas e analíticas no manejo do instrumento da desapropriação, agravadas pelas lacunas da lei em tema de avaliação e critérios para se definir justo preço, indica que teremos que adequar nossa legislação para que ela possa racionalizar o nosso desenvolvimento urbano e permitir, de forma efetiva, uma distribuição mais eqüitativa de seus custos e benefícios.

É certo que não se indica uma adoção pura e simples dos modelos estrangeiros ao nosso sistema legal, mas não há dúvida de que os modelos estrangeiros podem servir de inspiração para a lapidação de nossas políticas de desenvolvimento urbano. 


\section{Capítulo 5}

\section{PROBLEMAS DE APLICAÇÃO DA DESAPROPRIAÇÃO NO BRASIL}

Para completar o entendimento da fixação do valor de indenização da desapropriação, este capítulo destacará problemas não diretamente ligados ao instrumento da desapropriação - como, por exemplo, o da desapropriação indireta e da limitação administrativa - mas que interferem em sua aplicação, em razão dos conflitos institucionais da Administração Pública e judicial brasileiras.

\subsection{Desapropriação indireta e instrumentos afins}

Após o estudo de processos judiciais de desapropriação, principalmente o que têm por objeto áreas situadas na Serra do Mar, constata-se a necessidade de se distinguir importantes instrumentos jurídicos: o da desapropriação, o da desapropriação indireta e o das limitações administrativas.

As desapropriações chamadas diretas são promovidas pelo Estado, consoante às finalidades estabelecidas em decreto de autoria do Chefe do Poder Executivo. As denominadas desapropriações indiretas, na verdade, correspondem às ações de indenizações e, no caso das da Serra do Mar, fundadas na limitação administrativa oriunda da legislação que criou o Parque Estadual da Serra do Mar, Decretos Estaduais nºs. 10.251/77 e 13.316/79.

Segundo informações da Procuradoria do Patrimônio Imobiliário do Estado de São Paulo, na pessoa do senhor procurador chefe Dr. Pedro Ubiratan Escorel de Azevedo 
(informação informal), ${ }^{37}$ há em tramitação, mais ou menos, 1200 ações ambientais, compreendidas nesse número ações de desapropriação direta e indireta.

Essa distinção é importante, pois o cerne das questões judiciais tratadas nos processos das áreas da Serra do Mar são os laudos de avaliação, em razão de limitações administrativas impostas por lei, embora alguns processos tratem das limitações naturais dessas áreas, o que impediria, de fato e não só de direito, sua exploração econômica.

Essas ações são denominadas pela jurisprudência como desapropriação indireta, uma anomalia do direito, pois referida designação refere-se à apropriação indevida por parte do Estado de áreas de particulares, sem o regular procedimento que a lei estabelece para a desapropriação. Como o tema é muito recorrente nos processos pesquisados, importante distinguir essas situações que são confundidas com o regular instrumento da desapropriação.

A desapropriação constitui-se na transferência compulsória de um bem, da esfera patrimonial do particular, para o domínio estatal, o qual poderá, ainda, em casos excepcionais, atribuí-lo a outrem. De qualquer maneira, sempre será o expropriado ressarcido pela privação patrimonial sofrida, mediante pagamento de indenização.

A fundamentação legal da desapropriação decorre, como já mencionado, do Decreto-Lei $\mathrm{n}^{\circ}$. 3.365, de 21 de junho de 1941 e Lei $\mathrm{n}^{\circ} .4 .132$, de 10 de setembro de 1962, que tratam, respectivamente, de desapropriação por utilidade pública e por interesse social. No entanto, quando utilizada pelo Poder Público como execução de atividade urbanística recebe a denominação de desapropriação urbanística e, nesse campo, ela excede seu conceito tradicional, com notáveis diferenças relativamente à desapropriação geral (SILVA, 2006).

\footnotetext{
${ }^{37}$ Número aproximado para julho de 2006.
} 
Por limitação administrativa entende-se toda imposição do Estado, de caráter geral, que condiciona direitos dominiais do proprietário, independentemente de qualquer indenização. Diferencia-se a limitação administrativa da desapropriação, por representar a imposição de medidas de caráter geral, impostas com fundamento no poder de polícia e em benefício de interesse público genérico, não gerando indenização ao particular. Como exemplo, temos as limitações impostas à propriedade pelo Código Florestal, tais como as áreas de preservação permanente ${ }^{38}$ e as áreas de preservação ambiental, esta última considerada unidade de conservação ${ }^{39}$ de uso sustentável. Já a desapropriação recai sobre bem específico de acordo com o fim público colimado, importando na indenização justa.

Compreendemos que no caso da restrição inviabilizar o aproveitamento econômico total do imóvel, deve haver indenização por parte do Poder Público, similar à caracterização da desapropriação. No entanto, muitas dessas áreas sequer poderiam ser exploradas por limitações da própria natureza, ou seja, suas características excluem o aproveitamento econômico.

O tema é objeto de preocupação de alguns países, que tentaram assinar acordo a este respeito $^{40}$. Tal entendimento ${ }^{41}$ é importante, visto que a limitação administrativa não gera direito à indenização, como é pressuposto, no caso da desapropriação.

\footnotetext{
${ }^{38}$ Para o Código Florestal, Lei 4771/65, art. $1^{\circ}, \S 2^{\circ}$, são áreas de preservação permanente, além das nominalmente arroladas no art. $2^{\circ}$ :

II - área de preservação permanente: área protegida nos termos dos arts. $2^{\circ}$ e $3^{\circ}$ desta Lei, coberta ou não por vegetação nativa, com a função ambiental de preservar os recursos hídricos, a paisagem, a estabilidade geológica, a biodiversidade, o fluxo gênico de fauna e flora, proteger o solo e assegurar o bem-estar das populações humanas; (Incluído pela Medida Provisória n n 2.166-67, de 2001)

${ }^{39}$ Unidades de conservação são espaços ambientais que têm importantes características naturais e são legalmente instituídos pelo Poder Público com objetivos de conservação. Possuem limites definidos e existem sob um regime especial de administração, ao qual se aplicam garantias adequadas de proteção. Ou seja, são as reservas biológicas, parques e estações ecológicas que nós conhecemos ou pelo menos já ouvimos falar ( Lei 9985/2000)

${ }^{40}$ Couso (2002) em trabalho intitulado "La Producción del Derecho Económico Internacional y la Necesidad de uma democracia cosmopolita, apresentado no SELA, Punta del Este, em junho de 2002, narra a preocupação da OECD (Organización para la Cooperación y el Desarrollo Económico) organismo internacional em que estão reunidos os países mais desenvolvidos do mundo, ao tentar propor um acordo para proteger investimentos estrangeiros em países que limitam o uso da propriedade.
} 
Discute-se ainda a caracterização da chamada desapropriação indireta, diante da limitação imposta, visto que antes da ocorrência do regular processo de desapropriação a Administração impede o uso livre da propriedade. A desapropriação indireta configura-se como a designação dada ao apossamento do imóvel particular pelo Poder Público sem obediência às formalidades do procedimento expropriatório, cabendo ao lesado recorrer às vias judiciais para ser plenamente indenizado, do mesmo modo da desapropriação (MELLO, 2003).

No entanto, às vezes, a Administração não se apossa diretamente do bem, mas lhe impõe limitações ou servidões que impedem totalmente o proprietário de exercer sobre o imóvel os poderes inerentes ao domínio; neste caso, também se caracterizará a desapropriação indireta, já que as limitações e servidões somente podem, licitamente, afetar em parte o direito de propriedade (DI PIETRO, 2003).

Como abaixo destacaremos, os primeiros julgamentos dessas ações foram no sentido de determinar a indenização dessas áreas. O fundamento era o de que a criação do Parque Estadual da Serra do Mar esvaziava o conteúdo econômico dessas propriedades.

Em entrevista realizada com o desembargador do Tribunal de Justiça do Estado de São Paulo Laerte Nordi, um dos julgadores contrários à tese de que a criação de parque enseja a indenização de seus proprietários, ele afirmou (informação informal) que as origens de todas as ações de desapropriação indireta tiveram origem no Decreto Estadual n ${ }^{\circ} 10251$, de 30 de agosto de 1977, que criou o Parque Estadual da Serra do Mar, dispondo, no art. 6º que

\footnotetext{
${ }^{41}$ Azuela e Herrera também abordam o problema da compensação nos casos de limitação à propriedade: "The issue of regulatory takings is probably the most popular topic of discussion in the law of eminent domain. In almost every developed country there is an ongoing discussion about regulation of the use of land that imposes so severe restrictions that should be considered as an expropriation and therefore should be compensated. Following the notion that property is a bundle of rights, the question is how many of the sticks in that bundle (or which of them) can be taken by the state in the name of a public interest without generating a right to be compensated for the loss.
} 
ficavam "declaradas de utilidade pública, para fins de desapropriação, por via amigável ou judicial, as terras de domínio particular abrangidas pelo parque ora criado."

Esse decreto foi assinado pelo governador do Estado de São Paulo, PAULO EGYDIO MARTINS, no uso de suas atribuições legais e com fundamento no artigo $5^{\circ}$, alínea “ $a$ ”, do Código Florestal, Lei $\mathrm{n}^{\mathrm{o}}$ 4771, de 15 de setembro de 1965, considerando "as condições excepcionais da Serra do Mar, por atender a finalidades culturais de preservação de recursos nativos e exibindo atributos de beleza exuberante, a flora que aí viceja, matas de formação subtropical com variadíssima ocorrência de valiosas essências, a fauna silvestre, sendo a Serra do Mar notável repositório de espécimes raros.”

Por sua vez, o Código Florestal, instituído pela Lei Federal n 4771, de 15 de setembro de 1965, dispõe em seu artigo $1^{\circ}$ :

\footnotetext{
"As florestas existentes no território nacional e as demais formas de vegetação, reconhecidas de utilidade às terras que revestem, são bens de interesse comum a todos os habitantes do País, exercendo os direitos de propriedade com as limitações que a legislação em geral e especialmente esta lei estabelecem. Parágrafo único: As ações ou omissões contrárias às disposições deste Código, na utilização e exploração das florestas, são consideradas uso nocivo da propriedade (art. 302, XI, " $b$ ", do Código de Processo Civil)".
}

Os artigos $2^{\circ}, 3^{\circ}$ e $4^{\circ}$ esclareceram quais as áreas de preservação permanente e o que seria de interesse público, enquanto o artigo $5^{\circ}$ previu a criação dos Parques Nacionais, Estaduais, Municipais e Reservas Biológicas, com a finalidade de resguardar atributos excepcionais da natureza, conciliando a proteção integral da flora, da fauna e das belezas naturais com a utilização para objetivos educacionais, recreativos e científicos. O mesmo artigo dispôs acerca das Florestas Nacionais, Estaduais e Municipais, com fins econômicos, técnicos ou sociais, inclusive reservando áreas ainda não florestadas e destinadas a atingir aquele fim, proibida qualquer forma de exploração de recursos naturais dos Parques Nacionais, Estaduais e Municipais, nos termos do parágrafo único do art. $5^{\circ}$. 
Se as limitações administrativas existiram desde setembro de 1965, muitas desde 1934, e se estava proibida “qualquer forma de exploração dos recursos naturais nos Parques Nacionais, Estaduais e Municipais”, bastava ao Poder Público fiscalizar e coibir eventual ação predatória de proprietários de imóveis situados nas áreas de preservação permanente, sem declarar, desnecessariamente, de utilidade pública, para fins de desapropriação, por via amigável ou judicial, as terras de domínio particular, como o fez no art. $6^{\circ}$ do Decreto Estadual $n^{\circ} 10.251 / 77$. Na visão acertada do ilustre Desembargador Laerte Nordi foi essa declaração de utilidade pública, equívoca, que permitiu aos proprietários dessas áreas a oportunidade, antes sequer imaginada, de obter extraordinárias indenizações, em áreas que deveriam respeitar as limitações administrativas, sem exploração econômica. Estas indenizações geraram grande prejuízo ao povo, ainda que se faça tudo para reverter o que se tem para indenizar, porque não há como o Estado se ressarcir do que se pagou indevidamente.

Sob esse enfoque, conclui-se que as limitações administrativas das áreas da Serra do Mar são de longa data, pelo menos desde a época da edição do Código Florestal. No entanto, há inúmeras decisões no sentido do cabimento da indenização, como abaixo destacamos.

\footnotetext{
"Indenização- Desapropriação indireta- Área declarada de utilidade pública, com finalidade de proteger a floresta, fauna e belezas naturais da região- Medida que produziu o esvaziamento econômico do direito de propriedade- Obrigação de indenizar, por não configurar limitação administrativa- Recurso não provido." (RJTESP-123/265).
}

"Administrativo. Desapropriação indireta. Área localizada no Parque Estadual da Serra do Mar. Tombamento. Reserva florestal. Restrição ao uso da propriedade. Indenização. Cabimento. Na esteira de interativa jurisprudência formada por este egrégio Tribunal, é indenizável, por desapropriação indireta, a área de terra tombada, para criação do Parque Serra do Mar - SP, se o apossamento administrativo esvaziou o conteúdo econômico da propriedade, ao provar seus proprietários de usar e fruir do bem, proibidas que estão de explorar os recursos naturais existentes".(STJ.1 ${ }^{\text {Ta Turma. }}$ Recurso Especial 47865-0/SP, DJU 05.09.1994). 
Vários pontos devem ser evidenciados neste entendimento que protege indevidamente o direito do proprietário atingido pelo Ato Administrativo emanado da Administração Pública (seja do Município, do Estado, da União Federal, ou mesmo de outros entes de administração indireta) obter a indenização.

A caracterização da limitação administrativa é um não uso, sem que ocorra apossamento. O que é afetado não é o direito de propriedade; mas sim o rol de possibilidades de usar um bem, como ocorre com a propriedade que se situa no interior da Serra do Mar, que se encontra recoberta pela Mata Atlântica.

Com efeito, parte considerável do Poder Judiciário entende que o impedimento do uso e do gozo da propriedade gera, evidentemente, um prejuízo, sem que tenha sido feito o apossamento, sem que preceda a ação de desapropriação regular, o que impõe ao Estado de São Paulo o dever de indenizar o proprietário, não só pela indenização da área que está impedido de utilizar para a exploração econômica, como também, a cobertura vegetal de que reveste o imóvel, na parte afetada pela servidão administrativa. ${ }^{42}$

O Supremo Tribunal Federal, no julgamento do Recurso Extraordinário $\mathrm{n}^{\circ}$. 100.717-6, de que foi relator o Ministro Francisco Rezek reconheceu, expressamente, que o potencial indenizável da madeira deveria ser solucionado com maior amplitude, afigurandose, por isso, inviável a simples exclusão das matas de preservação permanente. O Ato Administrativo, portanto, está ínsito no art. $5^{\circ}$, inciso XXIV, e no $\S 2^{\circ}$, do art. 183 da Constituição Federal 1988.

\footnotetext{
${ }^{42}$ As decisões a respeito da indenização da cobertura vegetal variam muito junto aos tribunais superiores. $\mathrm{O}$ Supremo Tribunal Federal, que analisa a constitucionalidade das decisões, tem o entendimento de que a cobertura vegetal é indenizável. Já o Superior Tribunal de Justiça, que analisa o cumprimento da lei federal, tem entendido que não cabe a referida indenização.
} 
Aduzem alguns que à desapropriação indireta se aplica, por "analogia", os mesmos preceitos da desapropriação regular. Entendemos de forma contrária: ao se analisar o instrumento da desapropriação, constata-se que o mesmo é uma exceção à regra geral do direito à propriedade. Em linhas gerais, por meio desse, o particular é compelido a entregar sua propriedade ao Estado, em prol da coletividade.

A autorização constitucional para o Estado interferir na propriedade particular foi admitida mediante cautela, entre as quais o pagamento justo e prévio valor da indenização em dinheiro.

Preferiu o Legislador usar o termo "indenização", para significar o valor do bem, ao considerar que existe prejuízo nessa coação, e que o pagamento deve cobrir este dano com antecedência. Esse é o sentido que o Poder Judiciário dá à expressão, mais amplo, e compreende a soma das verbas que comporão o justo preço.

Naturalmente, se há a ausência do prévio ajuste sobre o preço, e se não há - por parte do Poder Público - a iniciativa da propositura da ação própria, não se pode falar em desapropriação. Dessa forma, quando o Poder Público afeta o bem do particular em caráter irreversível, sem nada pagar ou propor, não desapropria: comete esbulho possessório, ou pratica ato ilícito.

Por tais motivos, o direito do lesado à reparação se funda na garantia constitucional do art. $5^{\circ}$, que assegura a "propriedade", juntamente com vida, segurança e liberdade. Essa garantia vem distinguida na Lei Civil, em seus quatro elementos: uso, gozo, disposição e reivindicação das mãos de terceiros, quer haja o apossamento administrativo, ou mesmo o ato administrativo que o impede de usar e de gozar o bem; nos casos em análise, o 
de derrubar a mata existente, ainda que seja muito controvertida a questão se cabe ou não indenização pela floresta.

Porém, o exercício da reivindicatória, que lhe asseguraria a devolução do direito de usar e de gozar da propriedade, de colher seus frutos naturais, das deteriorações e perdas e danos, não é viável pela destinação irreversível do bem, que se vê afetado pela declaração de que está o mesmo albergando uma reserva florestal, para a preservação da Mata Atlântica, ou para manter incólume o Parque da Serra do Mar, ou preservar o Parque da Cantareira e tantos outros que foram criados.

A reivindicação do bem - ainda que esteja ausente o esbulho por parte da Administração Pública - converte-se na apuração e pagamento de seu valor, pela circunstância de que sendo vedado derrubar a mata que está em formação no imóvel, não desnatura a legitimidade jurídica do proprietário, levando à conclusão que ação é real e não pode ser assemelhada às ações pessoais.

Remanesce a indenização pela afetação do imóvel, que o torna não utilizável economicamente em razão da limitação imposta. Com efeito, entendendo que a criação do Parque Estadual da Serra do Mar esvazia o conteúdo da propriedade, ensejando indenização temos:

"É sabido que modernamente a propriedade deixou de ser absoluta, para sofrer limitações em benefício da coletividade". Após garantir o direito de propriedade, a Constituição Federal da República deixou expresso que "a propriedade atenderá a sua função social" (artigo 5º incisos XXII e XXIII), daí ser admissíveis as chamadas limitações administrativas, as quais, sem anular os poderes inerentes ao domínio, procuram atender ao interesse público.

No entanto, no caso sob exame, a rigorosa proibição de qualquer forma de exploração dos recursos naturais não pode ser tida como uma limitação administrativa, pois, a expressão "qualquer forma", utilizada pelo legislador aniquila o direito de propriedade. No julgamento de caso análogo, a Egrégia Décima Quarta Câmara Civil, fundada nas lições de FORSTHOFF e HELY LOPES MEIRELLES, assentou, pelo voto do eminente Relator, o Desembargador Dínio Garcia: "a limitação administrativa apenas restringe o exercício das faculdades inerentes ao domínio, mas não o atinge substancialmente, e muito menos o aniquila. Mas se, a 
pretexto de limitar a propriedade a restrição vai tão longe a ponto de anulá-la em seu conteúdo essencial, ou prejudicá-la sob aspectos decisivos, o caso será de desapropriação

Ou, como ensina FORSTHOFF ("Lehrbuch des Verwaltungsrechts", vol. I/302, $7^{\text {a }}$ ed.), o que caracteriza a desapropriação é a mudança da destinação do bem (Zweckentfremdung), ou a cessação do uso conforme à função do bem: "se a lei regulamenta o direito de propriedade respeitando a destinação do bem, ou se contenta em impor ao proprietário obrigações que permitem um uso conforme à função do bem, o direito do proprietário fica submetido a restrições que permanecem nos limites do que permite a função social; as leis de locação podem ser invocadas como exemplo. Se, ao contrário, é imposta ao proprietário uma obrigação que altera a destinação do bem já não se trata de simples função social do direito de propriedade (RT vol. 611/72)"

O Tribunal de Justiça do Estado de São Paulo, em voto relatado pelo Desembargador Olavo Zampol, assim decidiu:

"Indenização - Desapropriação - Mata virgem - Exclusão - Inadmissibilidade Acessão natural que exibe valor expressivo e que não pode ser negado ao proprietário que a perde - Indenização devida (Ap. Cível N. $75.713-2$ )”.

Segundo referido desembargador a mata virgem constitui expressivo valor econômico. Não importa se, num dado momento, é-lhe proibido derrubar, de modo possa converter-se em produtos comerciáveis. Pelo contrário. Sua não-derrubada representa valor ecológico, que supera sua transformação em lenha ou carvão.

Em outro julgado, decidiu-se que o valor intrínseco da mata não se vincula ao fato dela ter ou não se constituído pelo homem. Como "acessão natural" exibe um valor expressivo, que não pode ser negado ao proprietário que a perde. Não se discute se é caso de benfeitoria ou não. Pouco importa. Vale por si. É indenizável. Uma área revestida de mata virgem vale mais que a despida de qualquer verde" (RJTJESP, LEX, 91/133).

O Supremo Tribunal Federal, também se orienta no mesmo sentido: 
"Desapropriação. Mata de preservação permanente. Indenizabilidade. As matas de preservação permanente são indenizáveis, visto que, embora proibida a derrubada pelo proprietário, persiste o seu valor econômico e ecológico".

A decisão acima, da lavra do Eminente Ministro Francisco Rezek, assinala o seguinte:

\begin{abstract}
"Hoje, talvez mais do que nunca, constitui despropósito pretender-se que o valor econômico da floresta, assentada sobre certa área expropriada, esteja resumido no seu potencial de corte para venda de madeira e corresponda, destarte, a zero quando proibido o corte pela legislação florestal. É certo que, neste caso, a primitiva intenção da empresa ora recorrida era abater árvores para comercializar-lhes a madeira, e não fruir da riqueza ecológica ou de qualquer das muitas outras formas de benefício que a propriedade de uma floresta importa consigo. Esta consideração subjetiva, contudo, não autoriza a entender que a interdição do desmatamento neutralizasse objetivamente o valor econômico da mata (RT 583/289)".
\end{abstract}

O Egrégio Superior Tribunal de Justiça também já decidiu a respeito do tema em

exame:

Ao direito do Poder Público de instituir parques corresponde a obrigação de indenizar em respeito ao direito de propriedade, assegurado pela Constituição Federal Federal. Há que se distinguir a simples limitação administrativa da supressão do direito de propriedade. A proibição de desmatamento e uso da floresta que cobre a propriedade é interdição de uso da propriedade, só possível com indenização prévia, justa e em dinheiro, com compensação pela perda total do direito de uso da propriedade e desaparecimento de seu valor econômico". (Resp. n. 19.630-0-SP, Rel. Ministro Garcia Vieira, julgado em 19.8.92).

Acórdãos mais recentes proferidos pelo Egrégio Tribunal de Justiça do Estado de

São Paulo têm, contudo, atribuído um novo enfoque à questão, como são os confeccionados pelo Desembargador Laerte Nordi, entrevistado para essa pesquisa, entendendo que a simples declaração de utilidade pública do bem não implica necessariamente desapropriação, que poderá não ocorrer em virtude de desistência do Poder Público, além do que é possível que a expropriação não se concretize em razão de haverem cessado os motivos de utilidade ou necessidade pública ou, ainda, de interesse social, ou, também, por ter ocorrido a caducidade do decreto declaratório respectivo. Ressaltando a existência de julgados que entendem que só 
pode haver desapropriação indireta quando ocorrer efetiva ocupação pelo Poder Público de determinada área privada:

\begin{abstract}
"Apossamento Administrativo- Ato decorrente do efetivo exercício da posse pelo Poder Público- Simples expedição do decreto criando parque estadual e autuação por infração ao Código Florestal são insuficientes para sua caracterização. O apossamento administrativo é ato que decorre do efetivo exercício de posse pelo Poder Público. Assim, a simples expedição de decreto criando parque estadual e autuação por infração ao Código Florestal por sis sós não constituem esbulho nem importam em imissão na posse (RT- 673/82)"
\end{abstract}

Diante do grande número de ações que ainda tramitam entendemos que várias decisões ainda podem surgir, mas é sempre importante resgatar preceitos importantes, sobretudo os que foram prestigiados pela Constituição Federal de 1988.

Destarte, em face do preceito constitucional da função social e ambiental da propriedade, há entendimentos de que quando ocorrem restrições, tratando-se de áreas de preservação permanente imposta pela lei, não surge o direito de indenizar.

Há entendimentos de que tanto as áreas de proteção ambiental, como a reserva legal são limites internos ao direito de propriedade e, por isso, em nenhuma hipótese são indenizáveis. Integram a essência do domínio, sendo com o título transmitido. Não importam em esvaziamento do conteúdo econômico do direito de propriedade. A desapropriação priva o particular do bem de que é proprietário; ora, não é isso que se dá com as áreas de proteção permanente e a reserva legal, pois o senhor dessas áreas não deixa de ser o proprietário original, o particular.

Para Machado (2001, p. 136):

"As florestas de preservação permanente do art. $2^{\circ}$ do Código Florestal, instituídas pelo próprio Código, tais são as suas características de generalidade, atingindo propriedades indeterminadas, devem ser incluídas como limitações administrativas... Entende-se, portanto, que as limitações contidas nas florestas de preservação permanente do art. $2^{\circ}$ não são indenizáveis pelo Poder Público.” 
Cabe salientar que as definições de limitações e restrições administrativas merecem diferentes valorações, como prescreveu o eminente jurista Meirelles (2001, p. 225): "para que sejam admissíveis as limitações administrativas sem indenização, como é de sua índole, hão de ser gerais, isto é, dirigidas a propriedades indeterminadas, mas determináveis no momento de sua aplicação (...).”.

Limitações administrativas são, por exemplo, o recuo de alguns metros das construções e terrenos urbanos e a proibição de desmatamento de parte da área florestada de cada propriedade rural. O vigente Código Florestal Brasileiro fixa esse limite em 20\% da área florestada. Mas, se o impedimento de construção ou desmatamento atingir a maior parte da propriedade ou a sua totalidade, deixará de ser limitação para ser interdição de uso da propriedade, e, neste caso, o Poder Público ficará obrigado a indenizar a restrição que aniquilou o direito dominial e suprimiu o valor econômico do bem (MEIRELLES, 2001).

Limitação administrativa e desapropriação também não se confundem. Com efeito, no tocante à desapropriação ocorre transferência da propriedade individual para o domínio do expropriante.

Segundo Silva (2006, p. 186), "limitação à propriedade privada constitui, portanto, gênero do qual são espécies as restrições, as servidões e a desapropriação". No entender do eminente jurista, a lesão ao direito de propriedade implica verdadeira desapropriação indireta: "No sistema brasileiro, a restrição que chegue a esses limites de sacrifício da propriedade resolve-se no que se chama de desapropriação indireta, com pertinente indenização que componha todos os prejuízos sofridos pelo proprietário”.

Quanto ao agente público a ser responsabilizado, importa saber qual a esfera de poder "limitou" o direito de propriedade, se foi federal, estadual ou municipal. Na hipótese em 
que mais de um agente público emana atos restritivos, cada um deve responder pelo que lhe couber.

Diante do exposto, entende-se que as mudanças de especificações para delimitação das áreas de preservação permanente constantes no Código Florestal, que provocaram conflitos entre as situações constituídas com base na legislação anterior e a que está em vigor, após observância às legislações estaduais e municipais, deve resguardar o direito daqueles que estavam em conformidade com as especificações estabelecidas a época. Se houver necessidade se constituir tais espaços, que sejam realizados mediante justa indenização, sempre mediante a análise de que, de fato, a limitação ou restrição impediu um aproveitamento econômico usufruído pelo proprietário.

\subsection{A divisão federativa no Brasil e seus reflexos nos julgamentos das desapropriações. Justiça Federal versus Justiça Estadual}

No Brasil, o Judiciário concentra a atividade de arbitrar ou fixar as indenizações, em processo judicial de desapropriação. Em outros sistemas, a atividade do Judiciário é de mero controle. O Código das Expropriações de Portugal, consistente na Lei 168/99 (arts. 38 e seguintes), retira do Judiciário a tarefa de fixar a indenização devida. Na falta de acordo, o Tribunal de Relação nomeia uma comissão de três árbitros e, após a decisão desta, caberá recurso para os tribunais ordinários, de maneira que a atividade não é, de regra, desenvolvida no processo judicial, fato que também pode ser observado na Lei de Expropriação espanhola $^{43}$, de 16 de dezembro de 1954, que remete tal tarefa a um júri de cinco integrantes (arts. 31 e 32).

\footnotetext{
${ }^{43}$ Na Espanha a indenização é fixada pelo "Jurado Provincial de Expropiación", órgão colegiado, o qual deve fundamentar as suas decisões, das quais cabe recurso contencioso-administrativo (artigos 31 a 35 da Ley de Expropiación Forçoza de 16/12/1954). Na Itália é da jurisdição exclusiva do juiz administrativo a controvérsia
} 
Com efeito, em razão da federação instituída com a Constituição Federal de 1988, a divisão do Estado Brasileiro, comporta os entes políticos União, Estados-membros, Municípios e Distrito Federal. Para essa divisão federativa, em tema de desapropriação, é possível o julgamento por duas justiças. O julgamento pertence à Justiça Federal toda vez que a ação de desapropriação ou desapropriação indireta tiver como parte interessada a União. À Justiça Estadual e seus respectivos tribunais cabem o julgamento das ações de desapropriação ou desapropriação indireta quando os interessados forem os Municípios, Estados-membros ou Distrito Federal.

Os recursos que discutem a constitucionalidade das decisões ou sua legalidade em face da Lei Federal, de ambas as justiças são submetidos, respectivamente ao Supremo Tribunal Federal e ao Superior de Justiça.

Durante as pesquisas realizadas para o presente trabalho junto a Justiça Federal que se situa em São Paulo, verificamos a tramitação de processos de desapropriação iniciados em 1980 e que até hoje aguardam solução em primeira instância.

Também verificamos ${ }^{44}$ que a área discutida no processo, localizada na Serra do Mar de São Paulo, no Município de Peruíbe, muito provavelmente coincide com área objeto de desapropriação indireta proposta em face do Estado de São Paulo, perante a Justiça Estadual, o que resultaria no recebimento de dupla indenização. Como os processos tramitam em justiças separadas fica difícil verificar a sobreposição de áreas que pedem indenização ora na justiça federal, ora na estadual. Destacamos que importante trabalho de doutorado apresentado à FAU/USP e que detalhou o problema da sobreposição de áreas e de dupla indenização de desapropriações indiretas em áreas da Serra do Mar (COSTA NETO, 2006).

sobre os atos, procedimentos, acordos e os comportamentos da administração pública e dos sujeitos a ela equiparados, e à jurisdição do juiz ordinário a fixação da indenização.

${ }^{44}$ Processo n. 95.03.047765-4 da $13^{\circ}$ Vara Federal . Partes União e Nicolau Núncio Vigorito 
Em virtude dos graves problemas que o Estado de São Paulo enfrenta na questão da sobreposição de áreas em processos que tramitam perante a Justiça Estadual é possível imaginar que essas mesmas questões se repitam junto aos processos que tramitam perante a Justiça Federal, situação que necessita de mecanismos que possibilitem a troca de dados entre as duas Justiças e obstaculizem que recursos do Estado sejam gastos em duplicidade.

Além disso, em função da Constituição Federal de 1988 possibilitar à União e aos Estados-membros legislarem de forma concorrente em matéria de direito urbanístico e ambiental ${ }^{45}$, nos casos em que haja limitações administrativas de mais de um ente da federação nesses temas, é muito provável que possa haver demandas nas duas justiças.

Sabemos que não é possível refazer o pacto federativo e suas respectivas competências delineadas pela Constituição Federal de 1988, exceto em virtude de uma nova ordem constitucional, mas é necessário estabelecer novos modelos institucionais, voltados para a eficiência do Estado onde se possa, por exemplo, compartilhar de um banco de dados único dos processos de desapropriação que tramitam nas duas justiças.

O tema é tão complexo, que muitas vezes existe conflito entre os próprios entes da União, como demonstra transcrição do resumo da medida cautelar, interposto junto ao Supremo Tribunal Federal, pelo Estado de Roraima:

Acórdão no .1255 Medida Cautelar/RR*

RELATOR: MIN. CELSO DE MELLO

EMENTA: DIREITO AMBIENTAL. CRIAÇÃO DE RESERVA EXTRATIVISTA. PROCEDIMENTO DE INSTITUIÇÃO DESSA UNIDADE DE USO SUSTENTÁVEL. NECESSIDADE DE REALIZAÇÃO DE CONSULTA PÚBLICA (LEI No 9.985/2000, ART. 22, §§ $2^{\circ}$ E $3^{\circ}$, C/C O DECRETO N ${ }^{\circ}$ 4.340/2002, ART. $5^{\circ}$, "CAPUT"). PRECEDENTE DO STF. INSTITUIÇÃO, PELA UNIÃO FEDERAL, DE RESERVA EXTRATIVISTA EM ÁREA QUE COMPREENDE TERRAS PÚBLICAS PERTENCENTES A UM ESTADO-

\footnotetext{
${ }^{45}$ Ver art. 24,I da Constituição Federal
} 
MEMBRO DA FEDERAÇÃO. EXISTÊNCIA DE POTENCIAL CONFLITO FEDERATIVO. INSTAURAÇÃO DA COMPETÊNCIA ORIGINÁRIA DO SUPREMO TRIBUNAL FEDERAL, COMO TRIBUNAL DA FEDERAÇÃO. PRECEDENTES. A QUESTÃO DA DESAPROPRIAÇÃO, PELA UNIÃO FEDERAL, DE BENS INTEGRANTES DO DOMÍNIO PÚBLICO ESTADUAL. POSSIBILIDADE DO ATO EXPROPRIATÓRIO, SUJEITO, NO ENTANTO, QUANTO À SUA EFETIVAÇÃO, À PRÉVIA AUTORIZAÇÃO LEGISLATIVA DO CONGRESSO NACIONAL (DL No 3.365/41, ART. $2^{\circ}$, § $2^{\circ}$ ). CONTROLE POLÍTICO, PELO PODER LEGISLATIVO DA UNIÃO, DO ATO EXCEPCIONAL DE EXPROPRIAÇÃO FEDERAL DE BENS INTEGRANTES DO PATRIMÔNIO IMOBILIÁRIO ESTADUAL. DOUTRINA. NECESSIDADE DE OBSERVÂNCIA DO REGULAR PROCEDIMENTO EXPROPRIATÓRIO, INCLUSIVE COM O RECONHECIMENTO DO DEVER DA UNIÃO FEDERAL DE INDENIZAR O ESTADO-MEMBRO. PRECEDENTES DO STF. CONFLITO ENTRE A UNIÃO FEDERAL E AS DEMAIS UNIDADES FEDERADAS, QUANDO NO EXERCÍCIO, EM TEMA AMBIENTAL, DE SUA COMPETÊNCIA MATERIAL COMUM. CRITÉRIOS DE SUPERAÇÃO DESSE CONFLITO: CRITÉRIO DA PREPONDERÂNCIA DO INTERESSE E CRITÉRIO DA COLABORAÇÃO ENTRE AS PESSOAS POLÍTICAS. RECONHECIMENTO, NA ESPÉCIE, EM JUÍZO DE DELIBAÇÃO, DO CARÁTER MAIS ABRANGENTE DO INTERESSE DA UNIÃO FEDERAL. INOCORRÊNCIA, AINDA, DE SITUAÇÃO DE IRREVERSIBILIDADE DECORRENTE DA CONSULTA PÚBLICA CONVOCADA PELO IBAMA. MEDIDA LIMINAR INDEFERIDA.

Diante das dificuldades federativas enfrentadas pelas administrações públicas no Brasil, que acabam refletidas em tema de desapropriação, a solução das controvérsias poderá ocorrer através de uma maior cooperação entre os entes da federação cujo arranjo institucional é estabelecido pela recente Lei de Consórcios Públicos ${ }^{46}$, o que exige uma ação mais planejada da União e Estados na criação de Unidades de Conservação, Parques, Reservas Ambientais e Estações Ecológicas cooperação que pode se estender para os casos que resultem em processos judiciais.

\footnotetext{
${ }^{46}$ Lei Federal no. 11.107/2005:

Art. $1^{\circ}$ Esta Lei dispõe sobre normas gerais para a União, os Estados, o Distrito Federal e os Municípios contratarem consórcios públicos para a realização de objetivos de interesse comum e dá outras providências.

$\S 1^{\circ} \mathrm{O}$ consórcio público constituirá associação pública ou pessoa jurídica de direito privado.

$\S 2^{\mathrm{o}}$ A União somente participará de consórcios públicos em que também façam parte todos os Estados em cujos territórios estejam situados os Municípios consorciados.
} 


\subsection{As dificuldades técnicas enfrentadas pelo Judiciário no julgamento de processos de desapropriações}

Como já destacado em capítulos anteriores, a legislação que regula desapropriação em tema de utilidade pública e interesse social não estabelece critérios para aferição da indenização e do justo preço. Além disso, os juízes nomeiam peritos que entendem de confiança, de forma muito subjetiva, situação que possibilitou que muitos peritos fossem indicados sem que tivessem formação técnica adequada para elaboração dos laudos.

Juízes entrevistados junto à Justiça Estadual e Federal entendem que o Poder Judiciário deveria ter em seus quadros funcionais peritos com a qualificação necessária para atuarem nas avaliações ou que a indicação recaísse em órgãos com reconhecida experiência e idoneidade em tema de avaliações e são unânimes em afirmar que a indicação de peritos de forma aleatória pode resultar em laudos de avaliações duvidosas.

Como o Judiciário brasileiro não possui apoio técnico em tema de avaliação e a formação dos juízes não permite uma leitura analítica dos laudos, ocorre uma verdadeira adoção do laudo como uma "caixa-preta" ${ }^{47}$. Nestas circunstâncias, os juízes acatam o valor fixado no laudo pelos peritos nomeados na base da "confiança", sem nenhuma análise a respeito dos métodos, parâmetros e até mesmo legislação que foram empregadas em sua confecção.

Essas dificuldades técnicas e o caráter meramente argumentativo dos laudos, sem embasamento em critérios claros de avaliação, são graves entraves para que o julgamento estabeleça o justo preço da indenização.

\footnotetext{
47 Para Bunge ( 1974), "caixas pretas" são procedimentos ou teorias sobre as quais se conhece apenas as "entradas" e as "saídas", não se conhece a dedução empregada, por isso sua adoção deve ser feita com cuidado, embora seja comum sua utilização em atividades de pesquisa.
} 


\subsection{Excesso de "judicialização" e ausência de planejamento em tema de desapropriação.}

O procedimento de desapropriação no Brasil é iniciado por decreto de utilidade pública ou interesse social de autoria do representante do Poder Público, entidade pública ou concessionária de serviço público, regularmente autorizado por contrato, que tenha interesse na área a ser desapropriada.

Conforme fundamentos de direito administrativo, todo ato administrativo, como é o caso do decreto expropriatório, deve atender a certos requisitos, notadamente os requisitos motivo e finalidade ou interesse público ${ }^{48}$. Como já mencionado anteriormente, as decisões de desapropriar áreas para atender a uma determinada utilidade pública ou interesse social são tomadas de modo isolado, ou seja, sem nenhum tipo de planejamento. Com o advento do Estatuto da Cidade é possível que esta prática sofra alterações, pois, para a desapropriaçãosanção é condição que as áreas a ela sujeitas estejam previstas no plano diretor.

Do mesmo modo, o Estatuto da Cidade dispõe de outros instrumentos alternativos à desapropriação, como o direito de preempção, que consiste em o Poder Público delimitar as áreas que tem interesse para futuros projetos e, no caso do proprietário aliená-las é obrigatório que se dê preferência ao Poder Público municipal. O mesmo padrão deveria ser seguido para as áreas a serem desapropriadas para atender a uma utilidade pública ou interesse social, para que as aquisições sejam compatíveis com o planejamento municipal.

Nesse sentido, as legislações estrangeiras disciplinam que as desapropriações para utilidade pública devam estar previstas anteriormente nos planos locais ou regionais.

Na Espanha, a Lei 6/1998:

\footnotetext{
${ }^{48}$ Sobre os requisitos essenciais dos atos administrativos ver obras de Hely Lopes Meirelles, Celso Antônio Bandeira de Mello e Maria Sylvia Zanella Di Pietro.
} 
Artículo 33. Legitimación de expropiaciones La aprobación de planes de ordenación urbana y de delimitaciones de ámbitos de gestión a desarrollar por expropiación implicará la declaración de utilidad pública de las obras y la necesidad de ocupación de los terrenos y edificios correspondientes, a los fines de expropiación o imposición de servidumbres.

Artículo 34. Funciones de la expropiación La expropiación por razón de urbanismo podrá aplicarse de acuerdo con las finalidades previstas en la legislación urbanística y, asimismo, por incumplimiento de la función social de la propiedad, con los requisitos previstos en la Ley de expropiación forzosa.

Em Portugal, Decreto-lei 380/1998:

Art. $85^{\mathrm{a}}$

O plano director municipal define um modelo de organização municipal do território nomeadamente estabelecendo:

$(\ldots)$

a) A identificação das áreas de interesse público para efeitos de expropriação, bem como a definição das respectivas regras de gestão;

Anotamos que a Constituição Federal de 1988 instituiu a obrigatoriedade de planejamento, vinculando o Poder Público ${ }^{49}$, regramento que começa a ser incorporado na Administração Pública, mas seus resultados só poderão ser medidos daqui a alguns anos.

A ausência de planejamento permite que áreas sejam desapropriadas sem que a finalidade alegada pelo Poder Público possa vir a ser concretizada, fato que faz surgir a tese de que a propriedade pública também deve cumprir uma função social ${ }^{50}$.

Além dessa ausência de planejar as desapropriações necessárias ao planejamento urbano municipal, nota-se que a lei não estimula a realização de acordo em processo de desapropriação o que redunda em inúmeros processos em tramitação junto ao Poder

\footnotetext{
${ }^{49}$ Art. 174 da Constituição Federal: "Como agente normativo e regulador da atividade econômica, o Estado exercerá, na forma da lei, as funções de fiscalização, incentivo e planejamento, sendo este determinante para o setor público e indicativo para o setor privado."

${ }^{50}$ Sobre o tema da função social da propriedade pública ver DI PIETRO, Maria Sylvia Zanella. Função Social da Propriedade Pública in Estudos em homenagem ao Professor Adilson Abreu Dallari. Belo Horizonte: Del Rey. 2004. p. 561 a 572.
} 
Judiciário. É certo que algumas administrações procuram promover a desapropriação de modo amigável, mas pelo grande número de processos dessa natureza que estão em tramitação ou aguardando solução para pagamento, pode-se afirmar que há um excesso de judicialização das questões expropriatórias no Brasil.

A título de exemplo, em Portugal, a Lei $n^{\circ}$. 168/99, assim dispõe sobre a desapropriação amigável: procurar chegar a acordo com o expropriado e os demais interessados nos termos dos artigos seguintes."
}

Entendemos que não é necessário que a lei estabeleça a necessidade de se iniciar o procedimento com a propositura de um acordo, o que é necessário é uma mudança de postura dos agentes públicos. Contudo, disposição legal nesse sentido poderia reforçar a importância do acordo nos casos de desapropriação e contribuir para modificar a prática brasileira de utilizar o Poder Judiciário para resolver questões que poderiam ser solucionadas em âmbito administrativo.

Desta forma concluímos que, além dos sérios problemas relativos à avaliação e indenização nas desapropriações, a ausência de planejamento e a inércia administrativa em estabelecer acordos com os proprietários das áreas que a Administração Pública tem interesse, são elementos que contribuem para a crise do instrumento na prática brasileira. 


\subsection{A possibilidade de questionamento judicial do decreto de utilidade pública/interesse social}

$\mathrm{O}$ art. $9^{\circ}$ do Decreto-Lei $n^{\circ} .3 .365$, de 21 de julho de 1941 veda ao Poder Judiciário, nos processos expropriatórios, a eventual avaliação da real utilidade pública do bem em questão. Além disso, há o art. 20 da Lei de Desapropriação que reforça tal posicionamento, alegando que apenas os vícios processuais ou questões relativas ao preço podem ser objetos de contestação, devendo as demais controvérsias ser resolvidas em ações autônomas.

Contudo tal dispositivo pode ser diretamente confrontado com o princípio constitucional presente no art. $5^{\circ}$, inciso XXXV da Constituição Federal, que determina que: “a lei não poderá excluir da apreciação do Poder Judiciário qualquer lesão ou ameaça a direito". Neste choque entre os dispositivos, Campos (1956, p. 191) ainda na época da vigência de Constituição Federal de 1946, na qual o dispositivo constitucional também se fazia presente, declarou: “O Art. $9^{\circ}$ do Decreto-Lei $n^{o}$. 3.365, de 21 de julho de 1941 é inconstitucional”.

Outros doutrinadores compreendem que uma vez que o dispositivo presente na Lei de Desapropriação contempla a possibilidade de verificação do interesse público pela via direta, não há que se falar em inconstitucionalidade.

Campos (1956, p. 177) observa que a expropriação não pode ser considerada meramente um poder discricionário:

\footnotetext{
"não só porque condicionado o seu exercício a um motivo ou a um fim, cuja a existência é suscetível de verificação, como também porque o ato de desapropriação se destina a modificar uma situação jurídica individual, formal e especificamente garantida ou assegurada na Constituição".
} 
Neste sentido entendemos que o art. $9^{\circ}$ do Decreto-Lei $n^{\circ}$. 3.365, de 21 de julho de 1941 não pode subtrair à apreciação do Poder Judiciário, no próprio processo de desapropriação, as condições constitucionais e legais que tornam legítimo o apoderamento da propriedade particular pelos agentes da autoridade pública.

O Decreto-Lei $n^{\circ} .3 .365$, de 21 de junho de 1941, quando impede que na ação de desapropriação se questione fatos alheios a vícios processuais ou preço, não impede que estes fatos e vícios sejam apreciados pelo Judiciário, uma vez que é permitida tal discussão em ação direta. Para o autor o que é ferido com tal dispositivo é na verdade o princípio da economia processual, pois a necessidade de se ingressar uma ação autônoma para a discussão de fatos presentes em outra ação em curso é irracional (SALLES, 2006).

Nestas ações diretas, em que pode ser questionada a utilidade pública da desapropriação, ou mesmo ser realizado um exame de legalidade do ato, verifica-se a possibilidade da apreciação do Judiciário, o que retira a inconstitucionalidade do preceito $9^{\circ}$ do Decreto-Lei no .3 .365 , de 21 de julho de 1941.

O que o autor ressalta é que a questão controvertida deveria ser passível de apreciação na mesma ação, a expropriatória. A fundamentação quanto a essa vedação se encontra na questão da necessidade de celeridade no processo expropriatório.

No entanto, o Poder Judiciário não acata a tese de que as questões relativas ao abuso de poder possam ser discutidas no próprio processo de desapropriação.

Neste sentido o Tribunal de Justiça de São Paulo:

"Desapropriação- Área de terreno expropriada por Prefeitura Municipal e destinada
a instituição particular - Pretendido abuso de poder por não objetivar o ato utilidade
pública - Defesa inadmissível no processo expropriatório - Recurso provido para o
fim de ser apreciado o mérito da ação. A ação expropriatória constitui processo
destinado, apenas, à avaliação de bens e à incorporação dos mesmos ao patrimônio 
público, nela não havendo lugar para discussão acerca da utilidade pública ( RT 249/216)."

Assim, resta ao prejudicado discutir os motivos e a finalidade pública do decreto de desapropriação em ação separada, muito embora nada impeça que a questão possa ser posta em análise no mesmo processo, pois a posição do judiciário pode mudar, a depender dos argumentos expendidos pelo proprietário e dos novos entendimentos a respeito de temas ligados ao direito administrativo.

\subsection{Conclusão}

Sem abandono da defesa do Estado da Lei, ou seja, do Estado de Direito, é certo que muitos postulados tradicionais não só do direito administrativo, mas também do uso do instrumento da desapropriação necessitam de um novo arranjo a fim de compatibilizá-lo com o atual estágio social e do Estado.

Embora o presente trabalho tenha como foco os problemas enfrentados nas avaliações, outras questões obstam a aplicação do instrumento de uma forma mais eficiente e, igualmente, necessitam de uma revisão não só legal, mas também conceitual. 


\section{Capítulo 6}

\section{A PRÁTICA DA INDENIZAÇÃO E ESTUdOS DE CASOS DE ÁREAS DESAPROPRIADAS}

Neste capítulo, abordaremos os métodos de avaliação das perícias realizadas nos processos judiciais, as etapas de fixação do valor da indenização e o estudo de casos que trabalham com estas ferramentas.

\subsection{Os métodos utilizados}

O Brasil não possui legislação específica para avaliação dos imóveis urbanos objeto de desapropriação por utilidade pública ou interesse social. Diante desta lacuna da lei, os peritos judiciais costumam utilizar como métodos de avaliação o comparativo de dados de mercado e o método indireto, denominado também de involutivo. ${ }^{51}$

No caso de avaliação de glebas, os métodos mais utilizados são o comparativo direto e o involutivo. Considerando as características do Parque Serra do Mar, o método comparativo direto não é recomendado, diante da escassez ou mesmo inexistência de outras glebas com as características assemelhadas da do parque avaliado sendo comercializadas.

Por sua vez, o método involutivo parte de uma hipótese de aproveitamento econômico da área para se chegar a um valor de indenização, modelo que também se mostra inadequado para as áreas, como as que compõem a Serra do Mar, diante das dificuldades de atividades econômicas nessas áreas. O método involutivo é conceituado no item 6.2.4.1 da Norma Brasileira NB502, nos seguintes termos:

\footnotetext{
${ }^{51}$ Os peritos se pautam pelas normas da:

NBR 5676 - NB 502 - 08/1995 - Avaliação de Imóveis Urbanos. SãoPaulo: ABNT,1995 NBR 8799 - NB 613 - 02/1985 - Avaliação de Imóveis Rurais, São Paulo: ABNT, 1985 Instituto Brasileiro de Avaliações e Perícias de Engenharia- IBAPE - Engenharia de Avaliações. São Paulo: PINI, 1974
} 
"Aquele baseado em modelo de estudo de viabilidade técnico-econômica para apropriação do valor do terreno, alicerçado no seu aproveitamento eficiente, mediante hipotético empreendimento imobiliário compatível com as características do imóvel e com as condições de mercado".

Contudo, as fórmulas para cálculo do empreendimento hipotético têm inúmeras variáveis e a literatura de engenharia de avaliações desenvolveu fórmulas para cálculo expedito, mas que se mostraram inadequadas para as avaliações da Serra do Mar.

A obra de Caíres (1974), em síntese, alerta que a fórmula para cálculo expedito tem restrições, devendo ser utilizada somente nos casos de "pequenas glebas cujo loteamento possa ser absorvido em prazos curtos, portanto com dispensa de cálculo de juros e fixando-se um lucro baixo, o que não é o caso das áreas tratadas nesses processos”.

Assim, a utilização desses métodos, adequados às desapropriações fundadas em utilidade pública ou interesse social de imóveis situados nas cidades, não é boa técnica para as avaliações ambientais.

Tomando por base os processos pesquisados em tramitação nas Varas da Fazenda Pública de São Paulo e em Cidades da região metropolitana, em algumas situações esses métodos também não são adequados, como verificamos no caso da desapropriação do Parque Guapituba, em Mauá e, em alguns casos envolvendo áreas maiores para desapropriação do Metrô.

Além disso, na composição final desses valores de indenização também merece destaque a imputação de juros compensatórios, criados pela jurisprudência para compensar o proprietário pelos lucros cessantes na utilização da área expropriada, e devidos, segundo a jurisprudência, desde a imissão na posse até o pagamento integral do preço, sob o fundamento de se cumprir o princípio da "justa indenização" previsto no artigo $5^{\circ}$, inciso XXIV, da Constituição Federal Federal. 
A criação dos juros compensatórios remonta à década de 1940, sendo instituída pela Súmula $164^{52}$ do Supremo Tribunal Federal, a despeito de qualquer legislação. Apesar das discussões a respeito da Súmula, assentou-se em definitivo a discussão pela Súmula $618^{53}$, também do Supremo Tribunal Federal.

Observa-se que a criação dos juros compensatórios teve por objetivo compensar a renda da terra que o proprietário deixou de auferir em virtude da desapropriação. Nos casos das desapropriações ambientais, referidas regras, não poderiam ser aplicadas, pois é improvável que seus proprietários auferissem renda de terras com as particularidades das compostas pela Serra do Mar, com encostas que constituem limitações naturais à exploração econômica.

A edição da Medida Provisória nº 1.577 de 24 de agosto de 2001 tentou disciplinar o percentual desses juros, limitando-o a até seis por cento ao ano, e indicando que esses juros não se aplicam às desapropriações indiretas. Uma ação direta de inconstitucionalidade, contudo, suspendeu por liminar, a aplicação desses dispositivos, ação que até agora está pendente de julgamento definitivo.

\subsection{A Caixa preta: o Laudo}

Os laudos produzidos nos processos de desapropriação no Brasil constituem-se em verdadeiras “caixas pretas" dentro de um processo judicial. É certo que o juiz tem que se concentrar em prestar justiça sendo ancilar o seu conhecimento sobre outros campos do saber para desenvolver a atividade jurisdicional. Por isso pode se valer de procedimentos periciais

\footnotetext{
${ }^{52}$ Súmula 164 do STF: “ No processo de desapropriação, são devidos juros compensatórios desde a antecipada imissão de posse, ordenada pelo juiz, por motivo de urgência".

${ }^{53}$ Súmula 618 do STF: "Na desapropriação, direta ou indireta, a taxa dos juros compensatórios é de $12 \%$ (doze por cento) ao ano.
} 
sobre os quais não se conhece a dedução e os métodos empregados para sua confecção, apenas as "entradas" e as "saídas" (BUNGE, 1974), pois necessita deste instrumento para poder decidir.

No entanto, ainda que inevitável, o uso dos laudos requer cuidados, principalmente em razão das conhecidas fraudes que foram perpetradas durante sua confecção.

Em nosso entender, uma primeira preocupação se concentra em saber se os métodos empregados e os respectivos cálculos realizados no laudo são de aceitação geral e, neste aspecto, mesmo o Brasil não possuindo legislação específica que estabeleça critérios para avaliação, seria conveniente apoiar-se em entendimento de instituições ou autoridades no campo da avaliação.

Por fim, em certas situações específicas, como são os casos de desapropriações ambientais, seria prudente que o juiz estudasse com mais cuidado os temas trazidos nos laudos, muitas vezes envolvendo questões de restrições legais incidentes sobre as áreas desapropriadas, ainda que não haja necessidade de se compreender exatamente todos os fundamentos dos métodos empregados, ou seja, não é necessário "desvendar" a "caixa-preta", mas é essencial que o juiz entenda a natureza e os princípios em que se baseia o laudo, para então se decidir sobre sua aplicabilidade e adequação ao caso concreto.

Ao analisarmos alguns processos de áreas inseridas no Parque Estadual da Serra do Mar, Parque Estadual de Jacupiranga e Estação Ecológica Juréia-Itatins, distribuídos em cinco processos, ainda sem decisão do Supremo Tribunal Federal, podemos resumir que a origem das indenizações distorcidas reside: 
a) no fato dos laudos periciais atribuírem valores acima daqueles encontrados no mercado, considerando-se que referidas áreas pudessem ter utilização econômica normal, e;

b) na imposição, sobre esse valor, das denominadas "condenações acessórias" relativas aos juros compensatórios, honorários de advogado, atualizações monetárias e outras verbas.

Nos casos das desapropriações situadas na área urbana da cidade de São Paulo e da Região Metropolitana, as distorções, como veremos a seguir, também têm relação com o método empregado, pois, para avaliação de imóveis maiores pode não existir as condições de concorrência necessárias para a aplicação do método comparativo.

Para Haddad (2002), em muitos casos, há uma crença cega na "verdade" que vem dos números, mesmo que sua adoção contrarie o bom senso. Importante destacar o seguinte trecho de seu estudo:

“..., constata-se nos laudos de avaliação, quando da aplicação do método comparativo, que raramente é feita verificação sobre se o requerimento da existência de uma condição de concorrência perfeita foi ou não atendida. Talvez porque a constatação de que ela não existe pudesse deixar o analista desprovido de uma de suas ferramentas mais queridas, sentindo-se como se estivesse nu."

Assim, diante das limitações dos métodos empregados para os casos comuns de desapropriação, ou seja, aquelas que tratam da utilidade pública ou interesse social, inferimos sua inadequação quando empregados nas avaliações de finalidade urbanística e ambiental.

\subsection{Etapas da fixação do valor}

Ao abordarmos o tema referente ao valor principal da indenização, explicitamos o que deve ser analisado nos laudos com base na insuficiente legislação brasileira e na jurisprudência. 
Verificamos que o valor da indenização deverá ser calculado pela composição do principal e do acessório.

Como já salientado, o valor da indenização se dá ao tempo da realização da avaliação. Anteriormente não havia tal previsão: a indenização era calculada no instante da declaração de utilidade pública. Obviamente tal critério não atendia a proposta constitucional, uma vez que os processos são lentos e vagarosos, tornando as indenizações injustas e defasadas pela inflação. Diante disso, muitos dos expropriados procuravam a via jurisdicional para atualizar o valor indenizatório.

A não correção monetária da indenização fere o principio constitucional de justa indenização, uma vez que, diante da extensa duração do processo, e a distância entre a avaliação e o pagamento faz-se necessário o reajuste monetário (SALLES, 2006).

Em 1965 houve alteração na lei de desapropriações possibilitando a correção monetária em casos que já houvesse decorrido mais de um ano desde a avaliação.

A necessidade de atualização monetária ocorre devido à inadimplência da Fazenda Pública, que não utiliza seus recursos na quitação de obrigações. Não podemos negar que o Poder Público no Brasil tem sido desidioso quanto à obrigação de quitar débitos a esse título contraídos por administrações anteriores, com propósitos quase sempre eleitorais. Usar o dinheiro público para realizar obras é muito mais lucrativo, do ponto de vista político, do que utilizá-lo para pagar indenizações expropriatórias, no mais das vezes decorrentes de procedimentos demagógicos de antecessores, pois, como já salientado, as decisões de desapropriar guardam pouca relação com o planejamento urbano.

Pacificou-se, quanto à correção monetária, o entendimento de que a Lei nº .6 .899 , de 08 de Abril de 1981. (arts. $1^{\circ}$. e $5^{\circ}$.) revogou parcialmente o disposto no $\S 2^{\circ}$. do art. 26 do 
Decreto-Lei $\mathrm{n}^{\mathrm{o}}$. 3.365, de 21 de julho de 1941, precisamente na parte em que este último dispositivo só admitia a correção monetária após o decurso de um ano a partir da avaliação. Revogou-o, em decorrência de diplomas legais posteriores, em que a correção monetária passou a ser feita com base em índices como ORTN e depois na OTN, no BTN, no IPC,54 etc., cuja variação é medida mensalmente.

Existem situações em que, para a imissão na posse do imóvel é necessária a oferta, e um posterior depósito do correspondente valor. De acordo com o art. $33, \S 2^{\circ}$ da Lei de Desapropriações "O desapropriado, ainda que discorde do preço oferecido, do arbitrado ou do fixado pela sentença, poderá levantar até $80 \%$ (oitenta por cento) do depósito feito para o fim previsto neste artigo, observado o processo estabelecido no art. 34".

Surge, portanto, a questão da correção monetária dessa oferta. Neste sentido, o Tribunal de Justiça de São Paulo afirmou que a correção deverá ser efetuada para fins de juros, cálculo da indenização e honorários advocatícios.

Em alguns casos, o juiz poderá atualizar a indenização no momento em que proferir a sentença, o que implicitamente exclui a correção realizada na época da avaliação, considerando-se apenas a da sentença.

Vislumbra-se que o início para o cálculo da correção monetária se dará com a avaliação pericial, pois se assume que o perito em seu laudo comporá o valor exato do bem no

\footnotetext{
${ }^{54}$ OTRN - Obrigações Reajustáveis do Tesouro Nacional - Foi criada em 1964 pela Lei n ${ }^{\circ}$. 4.357, de 16 de julho de 1964, regulamentada pelo Decreto n. 54.252/64, de 03.09.1964 e vigorou até 1986, quando foi extinta com a edição do Decreto-Lei n. 2.284, de 10 de março de 1986.

OTN - Obrigação do Tesouro Nacional - Criada com o Decreto-Lei n.. 2284, de 10 de março de 1986, em seu artigo $6^{\circ}$, e extinta com a adoção da Lei n.. 7.730/89, de 31 de janeiro de 1989.

BTN - Bônus do Tesouro Nacional - art. $5^{\circ}$ da Lei 7777/89, extinção Lei 8177/91

IPC - Índice de Preços ao Consumidor, substituiu a OTN, conforme art. 11 da Lei n. 7.730/1989
} 
tempo de sua avaliação. Entretanto, há de se ressaltar que, nos casos em que a data do laudo e da avaliação não coincidir, a última será preponderante (SALLES, 2006).

O Brasil viveu uma situação muito peculiar em tema de inflação em alguns momentos políticos e econômicos que afetaram diretamente a correção monetária das indenizações, são eles: o Plano Cruzado, que congelou as correções monetárias das indenizações; o Plano Verão, que congelou, pela via legal, os salários, e; o Plano Collor, que regulamentou o encerramento da indexação da economia.

Em nossas entrevistas, os Juízes reputaram a esses períodos de inflação o valor elevado dos precatórios judiciais pendentes de pagamento por parte das administrações públicas.

Esses planos, acompanhados de grandes indagações quanto ao alcance da justa indenização, uma vez que, apesar do fim da indexação econômica a inflação ainda persistia. Contudo, não havia mais o BTN para realizar os cálculos para o reajuste, o que dificultou ainda mais estabelecer como essa atualização seria realizada. A jurisprudência, diante de tal situação passou a adotar o IPC para o cálculo das atualizações monetárias das indenizações.

Voltando aos precatórios, durante o período do Cruzado, as indenizações eram expressas em ORTN, e não em uma quantia fixa, o que facilitaria a conta na data do pagamento. Contudo, tal procedimento foi tido como inconstitucional (SALLES, 2006).

Do ponto de vista prático, a conversão do quantum relativo às indenizações em ORTN consubstanciava medida de excelentes resultados. Com efeito, impedia o lamentável expediente das Administrações Estaduais e Municipais de procrastinarem a satisfação de seus débitos, quase sempre contraídos por demagógicas administrações anteriores, e cujo pagamento era, por isso mesmo, encarado com má vontade, porque dificultava a execução de 
obras pelos administradores encarregados de saldar aqueles débitos por eles não assumidos (SALLES, 2006).

Com efeito, além da atualização monetária, sobre o valor principal incide o cômputo dos controvertidos juros compensatórios.

Os juros compensatórios são aqueles devidos em razão da imissão antecipada na posse, nas desapropriações diretas, ou da ocupação do imóvel, nas desapropriações indiretas.

Ressaltamos que está ganhando força a tese de que para a incidência de juros compensatórios é necessário comprovar-se a rentabilidade do imóvel, muito embora, tradicionalmente, a idéia é a de que não há necessidade de o imóvel em questão ser rentável para que os juros sejam devidos ao expropriado, mas sim a sua ocupação (SALLES, 2006).

Quanto às desapropriações indiretas, muitas questões foram suscitadas em torno do tema e da data correta para a contagem dos juros compensatórios. O que ocorreu foi um processo evolutivo, que primeiramente compreendia como a data correta para o cálculo a da avaliação.

Posteriormente, o STF elaborou uma Súmula contendo: "Na chamada desapropriação indireta, os juros compensatórios são devidos a partir da perícia, desde que tenha atribuído valor atual ao imóvel". Até que por fim, o entendimento jurisprudencial passou a se pautar na data de ocupação do imóvel pelo expropriante, para o inicio da contagem dos juros compensatórios.

Cumpri-nos observar, que se o expropriado detém a posse do bem expropriando até o pagamento definitivo da indenização, não há fundamento para condenar o expropriante 
em juros compensatórios, uma vez que o expropriando não ficou privado dos frutos que o bem produziu ou poderia ter produzido.

O STF, ainda, fixou o percentual dessa taxa: "Na desapropriação, direta ou indireta, a taxa dos juros compensatórios é a de $12 \%$ ao ano". Referida taxa ainda permanece em vigor, tanto nos casos de desapropriação direta como na indireta, conforme pode ser comprovado pelos processos pesquisados para esse trabalho.

Os citados juros compensatórios incidem sobre o bem monetariamente corrigido e não incidem sobre o depósito complementar da oferta, feito pelo expropriante (SALLES, 2006).

Existem também os chamados juros moratórios, que consistem naqueles decorrentes do atraso no cumprimento obrigacional. Quanto a essa espécie de juros, a questão controvertida não se figura quanto a incidência ou não dos mesmos, mas sim, na possibilidade de incidência destes sobre os já tratados compensatórios.

Quanto à questão da cumulação de juros compensatórios e moratórios o STJ editou a Súmula 12 que consiste: “Em desapropriação, são cumuláveis juros compensatórios e moratórios". E ainda, a Súmula 102 que afirma "a incidência dos juros moratórios sobre os compensatórios, nas ações expropriatórias, não constitui anatocismo vedado em lei”. 55

Atualmente a jurisprudência é pacífica quando se trata da incidência das duas espécies de juros (moratórios e compensatórios).

O entendimento pauta-se no trânsito em julgado para o início da contagem dos juros de mora, sejam nas desapropriações diretas ou indiretas. Neste sentido, o STJ

\footnotetext{
${ }^{55}$ Entende-se por anatocismo a cobrança de juros sobre juros o que, em princípio, é vedado pelas leis brasileiras.
} 
posicionou-se no assunto com a Súmula 70, que se apresenta nos seguintes termos: “os juros moratórios, na desapropriação direta ou indireta, contam-se desde o trânsito em julgado da sentença".

Anote-se que importante modificação com relação a esse entendimento foi introduzida pela edição da Medida Provisória nº 2.183-56 de 24 de agosto de 2001 que adicionou à Lei de Desapropriações o art.15-B que dispõe:

\footnotetext{
"Nas ações a que se refere o art. 15-A, os juros moratórios destinam-se a recompor a perda decorrente do atraso no efetivo pagamento da indenização fixada na decisão final de mérito, e somente serão devidos à razão de até seis por cento ao ano, a partir de $1^{\circ}$ de janeiro do exercício seguinte àquele em que o pagamento deveria ser feito, nos termos do art. 100 da Constituição".
}

Para Salles (2006) tal previsão legal fere diretamente o princípio da justa indenização, assim como o art. 100 da Constituição Federal de 1988, que prevê:

"É obrigatória a inclusão, no orçamento das entidades de direito público, de verba necessária ao pagamento de seus débitos oriundos de sentenças transitadas em julgado, constantes de precatórios judiciários, apresentados até $1^{\circ}$ de julho, fazendose o pagamento até o final do exercício seguinte, quando terão seus valores atualizados monetariamente".

Esclarece que a permissão desse dispositivo da Constituição Federal tem razões orçamentárias, por isso permite-se efetuar o pagamento até o final do exercício seguinte àquele em que o precatório foi apresentado, desde que o tenha sido até $1^{\circ}$ de julho. Entretanto, no dia em que se efetuar o pagamento, os valores constantes do precatório deverão estar atualizados monetariamente, inclusive os dos juros moratórios e compensatórios devidos até a data do efetivo pagamento de indenização e conclui que a norma constante do art.15-B, além de violar o princípio constitucional da justa indenização (inc. XXIV do art. $5^{\circ}$ da CF), fere, também, o princípio da moralidade (art.5º, LXXIII e 37 da Constituição Federal da República), não podendo ser cumprida, pois se trata de medida provisória que ainda não foi convertida em lei, nos termos do art. 62, § $3^{\circ}$, da Carta Magna (SALLES, 2006). 
Em suma, o cálculo parte do valor do bem desapropriado, encontrado pelo perito no laudo aceito por sentença transitada em julgado, corrigindo-se monetariamente esse valor até a data do efetivo pagamento. Em seguida, sobre o valor assim corrigido, calculam-se os juros compensatórios, levando-se em conta a data da imissão de posse provisória (nas desapropriações diretas) ou a da ocupação (nas indiretas), como termo inicial, e o dia do efetivo pagamento, como termo final.

Ressalve-se que esse não é o entendimento da Medida Provisória no 2.183-56, de 24 de agosto de 2001, porém sua aplicação está suspensa por força de uma ação que questiona sua constitucionalidade perante o Supremo Tribunal Federal. Para referida Medida Provisória os juros compensatórios são computados somente até a expedição do precatório, após só deve incidir os juros de mora.

Salientamos também, que em razão de um estudo realizado pela Fundação Getúlio Vargas para os Municípios que compõem o Consórcio Intermunicipal do Grande ABC, alguns desembargadores do Tribunal de Justiça do Estado de São Paulo estão revendo a fórmula de calcular o montante da indenização e, por exemplo, não estão aceitando a incidência de juros compensatórios após a expedição do precatório, além de também reverem a tabela que era utilizada para o cálculo da correção monetária, pois, segundo estudo da Fundação Getúlio Vargas, continha sérias distorções, que elevavam o montante final da indenização.

O estudo da Fundação Getúlio Vargas, na época, apontava:

“Temos como resultado destas posturas, decisões que remuneram o expropriado em padrões muito superiores aos de mercado". Neste ponto, parecem ferir alguns princípios constitucionais que balizam a atividade jurisprudencial e a postura do Estado em face do interesse público.

São, em primeiro lugar, decisões injustas, se admitirmos que justo fosse pagar ao expropriado o melhor rendimento que ele pudesse obter no mercado, caso tivesse tido acesso ao dinheiro no momento da desapropriação ou da perda da posse. Em segundo lugar, são decisões que se encontram em desacordo com o princípio constitucional da razoabilidade. ”(FUNDAÇÃO GETÚLIO VARGAS, 2001, p.52) 
Outra fonte de debate nas ações de desapropriações consiste no pagamento de honorários advocatícios, com base no princípio da sucumbência ${ }^{56}$. No art. $27, \S^{\circ}$ da lei de desapropriações dispõe: “A sentença que fixar o valor da indenização quando este for superior ao preço oferecido condenará o desapropriante a pagar honorários do advogado, que serão fixados entre 0,5 (meio) e $5 \%$ (cinco por cento) do valor da diferença, observado o disposto no $\S 4^{\circ}$ do art. 20 do Código de Processo Civil, não podendo os honorários ultrapassar R\$ 151.000,00 (cento e cinqüenta e um mil reais)".

Há de se lembrar que o caso do pagamento dos honorários advocatícios ultrapassa a questão do princípio da sucumbência, pois se vê atrelado ao conceito de justa indenização nos processos expropriatórios. Isso em razão de, não se poder onerar o expropriado com custas processuais e advocatícias.

Atualmente, vêm se empregando o art. $27, \S 3^{\circ}$ da lei de desapropriações, que estabelece o percentual de 0,5 a $5 \%$ da diferença entre a oferta e a sentença para fins de honorários advocatícios, e sobre eles também deve recair as atualizações monetárias necessárias.

\subsection{Estudos de casos}

\subsubsection{A experiência das indenizações ambientais no Estado de São Paulo.}

A Procuradoria do Estado de São Paulo publicou os principais os processos de desapropriação direta e indireta que tiveram como objeto áreas protegidas localizadas na Serra do $\operatorname{Mar}^{57}$.

\footnotetext{
${ }_{57}^{56}$ A parte perdedora em uma demanda judicial é considerada sucumbente.

57 PROCURADORIA GERAL DO ESTADO DE SÃO PAULO - Centro de Estudos - biblioteca virtual Trabalho sobre as ações indenizatórias - htpp//www.pge.sp.gov.br -São Paulo, 2005.
} 
Em razão da inadequação da utilização de modelos tradicionais às desapropriações ambientais, em muitos casos, a Procuradoria Geral do Estado pôde ingressar com ação rescisória, muito embora, o embasamento mais forte dessas rescisórias ${ }^{58}$ foi fundado na falta de comprovação de titularidade da área por parte dos autores das ações de desapropriação indireta.

Além disso, em muitos casos, as avaliações partiram da hipótese de se poder extrair a madeira dessas áreas, o que foi objeto de avaliação separada da área do terreno, ignorando-se a proibição de legislações anteriores a da criação do Parque Estadual, como o Código Florestal, que impediam a remoção dessa vegetação.

Tendo por base o ano de 1998, essas ações rescisórias suspenderam o pagamento de mais de $\mathrm{R} \$ 1.200 .000 .000,00$ (um bilhão e duzentos milhões de reais). Essas ações rescisórias tiveram por objeto decisões judiciais transitadas em julgado, que acolheram o pedido dos proprietários dos imóveis abrangidos pelo Parque Estadual da Serra do Mar, condenando o Estado à indenização total dos mesmos, os quais teriam perdido integralmente a possibilidade de serem explorados economicamente.

Nada obstante essas decisões terem sido proferidas pelos Tribunais Superiores do País, o fato é que seus fundamentos foram estabelecidos à luz de um conceito superado de direito de propriedade, que não mais tem aplicação depois da Constituição Federal. Além desse descompasso com o novo paradigma de propriedade, examinando-se as situações fáticas dos inúmeros processos de desapropriação indireta aforados, em virtude da criação do Parque Estadual da Serra do Mar, constata-se que a mera edição do referido Decreto Estadual não

\footnotetext{
${ }^{58}$ Ação rescisória é a medida judicial apta a questionar uma decisão que transitou em julgado, no prazo de dois anos a contar da publicação do trânsito em julgado (art. 495 do Código de Processo Civil Brasileiro)
} 
interferiu na exploração econômica dos imóveis situados nos respectivos limites geográficos, posto que, pela localização dos mesmos, impossível qualquer espécie de exploração lucrativa.

No entanto, em muitos casos o prazo para a propositura da ação rescisória escoou, e o que se tem discutido é se uma decisão judicial, ainda que transitada em julgado e que afronte a Constituição, tem o condão de surtir efeitos, pois se considerada inexistente sob a ótica jurídica, não necessitaria ser cumprida. Esses argumentos surgem em razão de inúmeras distorções periciais, em processos com trânsito em julgado ocorrido há mais de dois anos, e que podem provocar potencial dano ao erário estadual.

Dentre as distorções pode-se citar: inclusão no cálculo do volume madeireiro passível de aproveitamento econômico da copadas árvores e galhadas, que não tem aproveitamento sequer como lenha; erros decorrentes da aplicação de índices; contagem do número de árvores existentes no local; desconsideração da impossibilidade de aproveitamento econômico dos produtos florestais em função de restrições técnicas e econômicas de exploração; distorções nos valores dos produtos florestais; distorções pela desconsideração do tempo de regeneração da floresta no cálculo do valor presente da renda que adviria da exploração desses produtos. Além disso, em alguns casos há sobreposição de imóveis de terceiros já pagos, e uma nova perícia, a fim de que a justa indenização prevista na Constituição Federal de 1988 seja observada, deve ser realizada ainda que já não haja prazo para a propositura de ação rescisória.

\subsubsection{O caso do Parque Guapituba - Mauá}

Em 12 de maio de 1993, pelo Decreto 4.964, o Município de Mauá declarou de utilidade pública uma área de 468.299,02 metros quadrados para fins de desapropriação, 
visando à criação do Parque Ecológico do Guapituba, o que originou o Processo Judicial

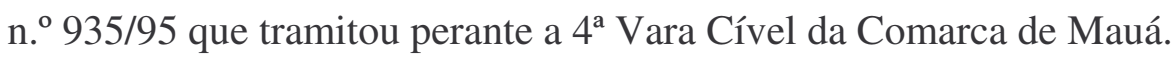

O processo judicial determinou duas perícias. A primeira perícia judicial, realizada pelo engenheiro Waldomiro Augusto de Souza, avaliou o parque em R\$ 31.395.000,00. As partes criticaram o laudo do juízo; o assistente técnico do expropriado, engenheiro Antonio Sergio Liporoni, fixou valor de $\mathrm{R} \$ 31.709 .326,00$ e, o assistente técnico do Município, Instituto de Pesquisas Tecnológicas - IPT, cujo parecer técnico fora coordenado pelo engenheiro Emílio Haddad, após arrolar vários pontos de discordância com o laudo judicial, estimou o valor da área em $\mathrm{R} \$ 1.712 .786,00$.

Em função da grande discrepância dos valores fixados entre o laudo fornecido pelo perito de confiança do juízo e o laudo confeccionado pelo assistente técnico do Município de Mauá, o Instituto de Pesquisas Tecnológicas de São Paulo, o juiz decidiu indicar novo perito para que um segundo laudo judicial fosse realizado. A segunda perícia, realizada pelo engenheiro Wilson Afonso Rosa, avaliou o parque em $\mathrm{R} \$ 22.110 .332,00$, o assistente técnico do expropriado, o mesmo engenheiro que criticou a primeira perícia, fixou o novo valor da área em $\mathrm{R} \$ 25.324 .181,00$ e o assistente técnico do Município de Mauá, o Instituto de Pesquisas Tecnológicas -IPT, manteve os valores estimados em R\$ 1.712.786,00.

Sucederam-se à apresentação dos laudos manifestações de ambas as partes tendo por objeto a diferença quanto aos valores obtidos. Após as manifestações, o juiz de primeiro grau sentenciou, em 29 de maio de 2001, fixando o valor da área em R\$ 25.324.181,00, valor atribuído pelo assistente técnico do expropriado em segunda perícia, para Fevereiro de 1997, valores que deveriam ser atualizados monetariamente a partir da 
realização do segundo laudo, acrescidos de juros compensatórios de $12 \%$ ao ano e juros moratórios a partir do trânsito em julgado.

Contra a sentença de primeiro grau, insurgiu-se o Município de Mauá, pleiteando a redução do valor da área ao valor fixado por seu assistente técnico do IPT, bem como, fossem reduzidos os juros compensatórios de $12 \%$ ao ano para taxe de $6 \%$ ao ano. O Tribunal de Justiça do Estado de São Paulo, acolhendo integralmente as críticas confeccionadas pelo Instituto de Pesquisas Tecnológicas, reformou a sentença de primeiro grau fixando o valor da área em $\mathrm{R} \$ 1.712 .786,00$, bem como, reduzindo os juros compensatórios de $12 \%$ ao ano para $6 \%$ ao ano, decisão que transitou em julgado em 26 de março de 2003, pois o Tribunal de Justiça julgou intempestivos os recursos extraordinário e especial interpostos pelo expropriado. O respectivo precatório foi expedido no início de 2006 para inclusão no orçamento.

Esse processo possui vários aspectos de crítica. Com efeito, a despeito de a Municipalidade ter se manifestado inúmeras vezes sobre os erros apontados por seu assistente técnico, o juiz de primeiro grau acolheu o laudo do assistente técnico do proprietário em segunda perícia, fixando o valor da área em $\mathrm{R} \$ 25.324 .181,00$, mais juros compensatórios de $12 \%$ ao ano e juros moratórios de $6 \%$ ao ano.

Importante frisar que o juiz de primeira instância embasou sua sentença em pontos de pouca relevância, ou seja, que pouco contribuíam na composição final da indenização da área expropriada. Referidos pontos foram todos afastados pelo laudo do IPT.

O juízo singular desconsiderou o laudo realizado pelo IPT e informações da Secretaria do Meio Ambiente do Estado de São Paulo que informavam incidir sobre a área 
restrições ambientais, previstas no Código Florestal, que importavam em obstar a remoção da vegetação de quase $50 \%$ da área expropriada, reduzindo a área possível de ser loteada, bem como as normas municipais que não permitem o uso de loteamento do modo como foi empregado pelo laudo oficial em seu projeto hipotético.

Ao contrário, justificou em sentença, equivocamente, a indenização das construções, da cobertura vegetal e a indenização de uma área supostamente desmembrável em virtude de a área expropriada fazer frente para uma avenida, sem levar em consideração as vedações da legislação municipal. Enfim, o juiz de primeiro grau permitiu que um perito, aplicasse a "lei" no caso concreto, sem se manifestar, um só momento, sobre a incidência dessas legislações sobre a área expropriada.

Em função da contundência dos apontamentos realizados pelo Município e seu assistente técnico, o Tribunal de Justiça do Estado de São Paulo reformou a decisão de primeiro grau, fixando outros critérios para determinar o valor da indenização.

Rechaçando os argumentos do laudo acolhido em primeiro grau, o Tribunal de Justiça de São Paulo, pela Sexta Câmara de Direito Público, cujo relator foi o Desembargador Coimbra Shmidt, em uma das passagens de sua decisão, assim se pronunciou:

\footnotetext{
"A perícia e as críticas que acolhem o cerne de suas propostas são imprestáveis ao desate porque não levaram em conta a legislação ambiental de interesse ao caso e a local concernente ao parcelamento do solo urbano, sem embargo da indevida agregação de parcelas relativas ao custo das benfeitorias em desconformidade com os propósitos e os critérios do método ao qual recorram os experts (método involutivo), como muito deixa claro o fluxograma reproduzido a f. 219."
}

A propósito, não se pode deixar de deplorar a opinião subjetiva do segundo perito, suficiente o bastante para comprometer integralmente a idoneidade de seu trabalho na medida em que desprezou por completo os efeitos da legislação ambiental sobre o caso, notadamente o Código Florestal, ao afirmar não se aplicar aos "casos de áreas urbanas", referir-se "apenas a áreas junto aos cursos d'água" e prestar-se "apenas e tão-somente para ajustar convênios, acordos e concessões relacionadas com a exploração florestal (f.583)". 
Contudo, embora o Município advogasse a tese do não cabimento dos juros compensatórios, pois o expropriado não auferia renda do imóvel, o Tribunal manteve essa verba, só que no importe de $6 \%$ ao ano, em virtude de "sua compatibilidade com a nova realidade de estabilidade econômica". Referida decisão, embora ainda considere os juros compensatórios na composição do valor da indenização, tem grande importância na jurisprudência por reduzir pela metade uma taxa fixada por muitos anos em desapropriações em todo o país no percentual de $12 \%$ ao ano.

A reforma da decisão assumiu como valor principal da área o fixado em laudo confeccionado pelo Instituto de Pesquisas Tecnológicas do Estado de São Paulo - IPT, qual seja, o valor de $\mathrm{R} \$ 1.712 .786,00$, ao qual deverão ser somados juros compensatórios de $6 \%$ ao ano, mais $6 \%$ de juros moratórios, critérios que reduzem muito o valor fixado em primeira instância.

O caso já tem precatório expedido para que o Município efetue o pagamento ao proprietário.

\subsubsection{A experiência das Varas da Fazenda Pública da Comarca de São Paulo}

Diante do grande problema dos valores elevados das indenizações em processos de desapropriação, no início dos anos de 1990, os Juízes das Varas da Fazenda Pública da Capital de São Paulo criaram o Centro de Apoio aos Juízes da Fazenda (CAJUFA) ${ }^{59}$ que é um grupo de estudos cujas conclusões foram adotadas nos processos de desapropriação para os quais possuíam competência jurisdicional para julgamento.

\footnotetext{
${ }^{59}$ Os procedimentos da Vara da Fazenda Pública de São Paulo só têm aplicação para os imóveis situados no território do Estado de São Paulo, cujo poder público desapropriante seja o Estado de São Paulo, o Município de São Paulo ou suas respectivas empresas.
} 
Com base nesses estudos surgiu um novo procedimento jurisprudencial para a avaliação provisória, com o objetivo de estabelecer uma situação justa e igualitária para ambas as partes, tendo em vista o valor irrisório ofertado para imissão provisória na posse por parte do Poder Público.

Esse novo procedimento ${ }^{60}$, adotado de forma mais consolidada até os dias de hoje, manifesta-se da seguinte forma: proposta a Ação e requerida a urgência na imissão da posse, o Poder Público oferece determinado valor de acordo com uma avaliação feita pelos seus técnicos. O juiz, então, determina a citação dos expropriados e no mesmo despacho nomeia o perito judicial para elaboração de laudo prévio.

Esse laudo prévio é que fixará o valor que deverá ser depositado pelo Poder Público no caso de urgência na imissão na posse. Após apresentado o laudo, realizado conforme as normas CAJUFA $^{61}$, o juiz determinará que a expropriante deposite o valor encontrado pelo perito judicial em sua análise técnica.

Assim, efetuado prévio depósito, o juiz intimará o expropriado que deverá requerer o levantamento de $80 \%$ do valor ali depositado e concordar com a imissão provisória na posse.

Após, o processo seguirá seu procedimento comum e o juiz determinará que o perito judicial elabore laudo definitivo, que será analisado pelos assistentes que serão nomeados pelas partes. Após os debates, o juiz proferirá sentença fixando o valor da indenização e demais cominações legais que serão analisadas no curso dessa exposição.

\footnotetext{
${ }^{60}$ O procedimento estabelecido pelos Juizes da Vara da Fazenda Pública da Comarca de São Paulo foi objeto de projeto de pesquisa, com nossa participação, desenvolvida pelo Prof. Dr. Emílio Haddad para o Lincoln Institute of Land Policy, cuja tema é Pesquisa sobre os novos procedimentos em processos judiciais de desapropriação do Poder Judiciário da Comarca de São Paulo. The Positioning of the Judiciary on Real Estate Valuation: the Case of Sao Paulo, Brazil, 2007.

${ }^{61}$ CAJUFA - Centro de Apoio aos Juízes da Fazenda Pública
} 
O CAJUFA é composto por peritos nomeados pelos juízes, e que sem ônus para Estado, disciplinam as normas técnicas ${ }^{62}$ a serem seguidas pelo perito que confeccionará os laudos judiciais. Não é o CAJUFA que elabora o laudo, e sim um perito nomeado que seguirá os seus parâmetros.

Com efeito, como já mencionado em outras passagens desse trabalho, no início do processo judicial o juiz nomeia um perito para realização do laudo prévio, que é pago pelo Poder Público expropriante. O laudo prévio é realizado segundo as normas estabelecidas pelo CAJUFA, cuja intenção é obedecer ao princípio constitucional da justa e prévia indenização em dinheiro previsto no inciso XXIV da Constituição Federal de 1988.

Este procedimento, em um primeiro momento, era aceito pelos tribunais superiores. Houve mudança de posicionamento e algumas decisões já consideram o procedimento adotado pelo CAJUFA como ilegal. Atualmente, a questão está novamente sendo julgada pelo Superior Tribunal de Justiça.

Como pode ser compreendido do acima esboçado, o Decreto-Lei que prevê o procedimento judicial de desapropriação data do ano de 1941, anterior a Constituição Federal da República, devendo ser ajustado à nova ordem urbanística, sem prejudicar qualquer das partes.

Os juízes entrevistados afirmam que o procedimento da lei é muito demorado, e a discussão de juros e correção monetária tornam o recebimento da indenização muito difícil e injusta para o expropriado. Culpam o Poder Público em determinar desapropriações sem prever em seus orçamentos o correspondente recurso de pagamento.

\footnotetext{
${ }^{62}$ Essas normas se baseiam nas normas do IBAPE.
} 
Sem dúvida, o depósito prévio evita a incidência de juros, principalmente os compensatórios, que elevam muito a dívida pública, impedindo assim, que alguns governantes deixem para os seus sucessores a incumbência do pagamento destas indenizações, além de representar uma economia aos cofres públicos, pois a demora no pagamento aumenta muito o valor da indenização.

Com a consolidação deste procedimento, ele foi estendido para todas as desapropriações, independentemente de haver pedido de imissão prévia na posse, com a nomeação de perito e a determinação imediata da avaliação provisória do imóvel desapropriado, em laudo reduzido e simples a ser apresentado em dez dias, cujas conclusões servirão de fundamento para a fixação, pelo juiz, do depósito a ser feito.

Os juízes acreditam que fica superado o problema da irrealidade do valor cadastral dos imóveis, que historicamente é sempre inferior ao valor de mercado, além de se obter dois justos resultados: são evitadas desapropriações oportunistas, para que administrações futuras paguem por elas e, desde logo, já se paga os desapropriados, permitindo-lhes um rápido encaminhamento de solução para os transtornos causados pela desapropriação.

O estudo do procedimento utilizado pelo Judiciário local em São Paulo se iniciou com entrevistas com os juízes que trabalham há mais tempo em julgamentos de processos de desapropriação. Atualmente, no fórum da Justiça local de São Paulo, trabalham 59 juízes, com atuação exclusiva nos processos em que a fazenda pública estadual ou municipal seja parte, como os casos dos processos de desapropriação.

Como há um Juiz Diretor dos processos da fazenda pública, Dr Juiz Fernando Figueiredo Bartoletti, optamos por entrevistá-lo. Entrevistamos outrossim, dois juízes que trabalham há duas décadas no fórum: Dr. Juiz Luiz Paulo Aliende e Dr. Juiz Romolo Russo. 
No roteiro de entrevistas procuramos indagar os juízes a respeito das principais dificuldades encontradas nos julgamentos das desapropriações, com vistas a entender a origem do procedimento criado por São Paulo; o que eles entendiam sobre os juros aplicados sobre o valor das indenizações; o que eles entendiam por justa indenização; se a Justiça local tem aplicado conceitos de direito urbanístico como a função social da propriedade e a recuperação de mais valias na fixação dos valores de indenização; qual o entendimento deles a respeito das superavaliações ocorridas em processos julgados na década de 1990 e a respeito da possibilidade de anulação destes julgamentos, ainda que o prazo dos recursos já tenha expirado.

Para o Juiz Luiz Paulo Aliende, a avaliação e a determinação de pagamento no início do processo impedem que o proprietário incorpore na indenização o valor das mais valias decorrentes da obra que o Poder Público ainda irá realizar situação difícil de controlar pelo procedimento da lei, em que a avaliação pode ocorrer muitos anos depois de instaurado o processo.

Como o interesse era analisar julgamentos atuais, sempre considerando que um processo tem uma tramitação de aproximadamente cinco anos, selecionamos alguns processos de pequenos e médios proprietários e de grandes proprietários. Ainda, selecionamos processos em que o Município é o interessado e outros em que o interesse é do Estado de São Paulo, através da Companhia do Metrô. Foram analisados 9 processos, sendo certo, que atualmente não tramitam na justiça local processos de áreas que envolvam a criação de parques ambientais, pois estes têm suas indenizações discutidas em recursos junto aos tribunais superiores. 


\subsubsection{Casos Pesquisados na Vara da Fazenda Pública do Estado de São Paulo}

Passamos a relatar os aspectos principais de cada processo pesquisado.

Dentre os processos de pequenas e médias áreas, destacamos:

\section{I- Desapropriação de área para expansão de linha de Metrô}

A ação analisada tramitou perante a $4^{\mathrm{a}}$ Vara da Fazenda Pública de São Paulo/SP, processo n. ${ }^{\circ}$ 583.53.2004.005405-9, requerente Companhia do Metropolitano de São Paulo, requerida Maria Aparecida Polato. A proprietária possuía imóvel com área de 276,63 m², imóvel este declarado de utilidade pública por meio do Decreto n 46.230 de 30/10/2001.

A Companhia do Metropolitano de São Paulo declarou de utilidade pública o imóvel localizado na Rua Teçaindá, n. ${ }^{\circ}$ 96, Bairro de Pinheiros, São Paulo, Capital para estender a linha de Metrô. O imóvel era residencial e seu valor venal, ou seja, seu valor para fins fiscais era o de $\mathrm{R} \$ 235.832,00$.

A Companhia alegou urgência para fins de imissão na posse após efetuar o depósito do valor provisório arbitrado pela Comissão de Peritos. Ofertou com a propositura da ação judicial $\mathrm{R} \$ 366.960,00$.

A proprietária, ao contestar a ação de desapropriação em 01de abril de 2004 em sede de preliminar de contestação, requereu avaliação prévia no caso de imissão provisória, devendo o valor estimado corresponder ao justo preço da indenização ou valor muito próximo, nos termos do artigo $5^{\circ}, \mathrm{XXIV}$ da $\mathrm{CF}$. 
No mérito impugnou o preço oferecido por achar ser este injusto e estar abaixo dos preços do mercado na localidade, pois a região é valorizada e o imóvel possui características que o valorizam.

Ao valor da indenização deverão ser acrescidos juros compensatórios de $12 \%$ ao ano a partir da imissão, calculado sobre a diferença do valor inicial e a condenação final, corrigido monetariamente consoante a Súmula 618 do STF; juros moratórios de $6 \%$ ao ano sobre a diferença do valor inicial e a condenação final, em caráter cumulativo e sobre juros compensatórios nos termos da Súmula 12 e 102 do STJ; honorários de 20\% nos quais deverão incidir sobre os juros compensatórios e moratórios, em caráter cumulativo, nos termos da Súmula 617 STF e 131 e 141 do STJ; despesas e custas processuais e correção monetária a partir da data do laudo final, devendo incidir sobre as parcelas que compõem o "quantum" indenizatório.

O laudo prévio foi realizado 21 de junho de 2004 e utilizou-se "Norma para avaliação de Imóveis Urbanos-95” do IBAPE/SP, fixando à indenização em R \$ 764.371,05. A imissão provisória na posse ocorreu em 14 de abril de 2005. O laudo definitivo de 12 de setembro de 2005 alterou pouco o valor do laudo provisório para fixar a indenização em $\mathrm{R} \$$ $746.200,00$.

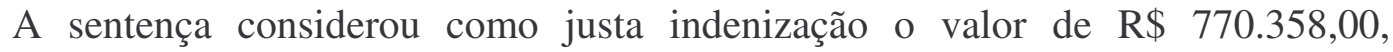
publicada em 27/11/2006.

Houve a complementação do valor faltante, sendo extinta a execução e determinada extração de carta de adjudicação após o trânsito em julgado.

Com efeito, o caso ilustra bem a demora para a conclusão do processo de desapropriação. Iniciado em 2001 com a publicação do decreto de utilidade pública, só foi 
concluído no final do ano de 2006, circunstância que explica a incidência dos juros compensatórios e moratórios, além da correção monetária da moeda, no valor da indenização, a fim de compensar o proprietário pela demora em receber a indenização. Se o processo judicial fosse mais ágil, ou se o Poder Público utilizasse maneira mais eficaz a via administrativa, ou seja, não se valesse do Poder Judiciário para decidir o valor da indenização, visando reduzir o tempo de tramitação do processo, haveria uma diminuição dos custos com a indenização e o proprietário não demoraria tanto em recompor seu patrimônio.

Verifica-se também que os critérios de avaliação foram pautados pelas normas do IBAPE, instituto de engenharia de natureza privada, pois, como já relatado anteriormente, no Brasil, os critérios de avaliação de imóveis não estão descritos nem em lei elaborada pelo poder legislativo e nem em decreto de origem do poder executivo.

Na avaliação são consideradas as normas de zoneamento onde se insere o imóvel, mas não há diálogo entre a Companhia do Metropolitano, que é empresa estatal regional, com os gestores e planejadores do Município de São Paulo.

Na cidade de São Paulo, os imóveis que se localizam nas proximidades de uma estação de Metrô recebem considerável incremento de valor, mas como não existe este diálogo entre a empresa pública regional e o Município, não existe política para recuperar as mais valias advindas com a extensão do Metrô, nem mesmo a cobrança da tradicional contribuição de melhoria.

\section{II - Desapropriação de área para expansão de linha de Metrô}

A ação analisada tramitou perante a $4^{\mathrm{a}}$ Vara da Fazenda Pública de São Paulo/SP, processo n. ${ }^{\circ}$ 583.53.2005.029861-0, tendo como Poder Público expropriante a Companhia do Metropolitano de São Paulo, e proprietários Umberto Pasqualetti e Juçara Maria de Araújo. 
Os proprietários e requeridos possuíam um imóvel com área de $122 \mathrm{~m}^{2}$, imóvel este declarado de utilidade pública por meio do Decreto Estadual n 44.003 de 20 de outubro de 2003.

A expropriante requereu urgência na imissão da posse e ofereceu o valor de $\mathrm{R} \$$ 128.080,25. O juiz, então, nomeou perito judicial para avaliação prévia do imóvel. O imóvel residencial da Rua Agostinho Gomes, n. 3455, apto.01, Bairro Ipiranga, São Paulo, Capital, foi decretado de utilidade pública para a extensão das obras do Metrô. Destaca-se que própria Companhia do Metropolitano entendeu que o valor fixado pelo Município para fins fiscais, ou seja, $\mathrm{R} \$ 56.235,00$ era abaixo do valor de mercado.

A empresa alegou urgência para fins de imissão na posse e efetuou o depósito do valor provisório arbitrado pela Comissão de Peritos, $\mathrm{R} \$ 128.080,00$.

Os proprietários em 16 de maio de 2006, em sede contestação requereram avaliação prévia no caso de imissão provisória, devendo o valor estimado corresponder ao justo preço da indenização ou valor muito próximo, nos termos do artigo $5^{\circ}$, XXIV CF.

No laudo prévio foi utilizada a "Norma para avaliação de Imóveis Urbanos"IBAPE/SP 2005 e a Norma Cajufa de 11/2004. Método comparativo direto. Valor unitário do terreno $\mathrm{R} \$ 395,30 / \mathrm{m}^{2}$ em abril de 2006. Valor total do terreno: $\mathrm{R} \$ 29.418,63$.

Para as benfeitorias foi utilizado o método empregado pela Comissão de Peritos nomeados pela Portaria 02/86 dos Juízes da Fazenda Pública de São Paulo/SP: H82N SINDUSCON em 04/06. Valor unitário de 929,78R $\$ / \mathrm{m}^{2}$. Valor total das benfeitorias: R\$ 104.382,62 que, somado ao valor do terreno, corresponde ao valor total de $\mathrm{R} \$ 133.801,25$ de indenização. 
A imissão provisória na posse ocorreu em 17 de agosto de 06 e o laudo definitivo de 22 de dezembro de 2006 alterou um pouco o valor da indenização para R \$134.407,00.

O assistente técnico da Companhia do Metrô avaliou o imóvel em R\$ 134.339,35 e o dos proprietários concordaram com o laudo. A sentença considerou como justa indenização o valor de $\mathrm{R}$ \$ 134.407,00, publicada em 24 de abril de 2007. Não houve recurso de nenhuma das partes.

O prazo para conclusão deste processo também foi demorado, mas o valor depositado no início do processo foi bem próximo ao valor fixado no laudo final.

As regras utilizadas para a avaliação tiveram fontes variadas, incluindo as formuladas pelo CAJUFA, situação que torna difícil a tarefa de compreensão do valor fixado no laudo. Também neste caso é possível verificar que não há menção às normas urbanísticas aplicáveis ao imóvel e nem o diálogo entre a Companhia do Metrô e os órgãos de planejamento da cidade de São Paulo.

Por fim, diante dos valores ofertados na inicial, muito semelhantes ao apurado no laudo, entendemos que a desapropriação poderia ter sido resolvida nas vias administrativas, sem a interferência do demorado processo judicial.

\section{III - Desapropriação para alargamento de via pública}

A ação analisada tramitou perante a $4^{\mathrm{a}}$ Vara da Fazenda Pública de São Paulo/SP, processo n. ${ }^{\circ}$ 583.53.2002.021349-4, sendo expropriante o Município de São Paulo, requeridos José do Carmo Bartolo e Sonia Garrido Bartolo. Os proprietários e requeridos possuíam um imóvel com área de 59,52 m², imóvel este declarado de utilidade pública por meio do Decreto Municipal n. 42.179 de 11 de julho de 2002. 
Parte da propriedade localizada na Rua Joaquim Ferreira Rocha, n 939, São Paulo,Capital foi decretada de utilidade pública pelo Município de São Paulo para alargamento de via pública. O Município de São Paulo depositou o valor de R 4.158,66 com a propositura da ação e salientou ter urgência na desapropriação.

O juiz determinou a realização de laudo provisório, embora o perito tenha apresentado como laudo definitivo em 01/06/00. O Laudo verificou a situação do imóvel na lei de zoneamento e utilizou o método comparativo direto e as normas do IBAPE/SP, atribuindo o valor de $\mathrm{R} \$ 4.424,00$ ao terreno expropriado.

Os proprietários concordaram com a avaliação prévia, sendo a sentença publicada em 19 de março de 2003 e em 28 de agosto de 2003 houve a imissão na posse.

Houve recurso do Município contra a fixação de juros e o Tribunal julgou procedente o em virtude de o valor ter sido depositado antes da imissão da posse por parte do Poder Público.

Entendemos que este é outro caso em que a atuação pública seria mais eficiente se a desapropriação tivesse sido resolvida amigavelmente, sem a necessidade de intervenção judicial.

\section{IV - Desapropriação de área para expansão de linha de Metrô}

A ação analisada tramitou perante a $4^{\mathrm{a}}$ Vara da Fazenda Pública de São Paulo/SP - Processo n. ${ }^{\text {o }}$ 583.53.2004.020759-7, tendo como expropriante Companhia do Metropolitano de São Paulo - Mêtro e proprietários Zibia Milani Gasparetto e outros. Imóvel objeto da desapropriação: Rua Jacques Callot, s/n, lotes 7, 6 e 5 da Quadra A, Cidade de São Paulo/SP. 
Decreto n. ${ }^{\circ} 48.473$ de 28 de janeiro de 2004. Finalidade: utilidade pública. Desapropriação total do imóvel (não residencial). Área de 883,16 m².

A Companhia do Metropolitano alegou urgência para fins de imissão na posse depois de efetuado o depósito do valor provisório arbitrado pela Comissão de Peritos e depositou valor de $\mathrm{R} \$ 410.400,00$ para ingressar no imóvel provisoriamente.

O laudo prévio foi realizado em 03 de dezembro de 2004 com base na "Norma para avaliação de Imóveis Urbanos-95” do IBAPE/SP.

A comissão de peritos aplicou redução de $20 \%$ sobre os valores obtidos na pesquisa efetuada, excepcionalmente correspondente à elasticidade das ofertas, devido ter-se observado um acréscimo especulativo no valor destas sem efetivas negociações, atribuindo-se ao imóvel o valor de R \$ 694.339,12.

O processo ainda encontra-se na fase de manifestação ao laudo. Os peritos não levaram em consideração normas urbanísticas, assim como não há informação se os proprietários possuem outros imóveis os quais serão valorizados com a obra.

Quanto aos processos de grandes áreas, destacamos:

\section{V - Desapropriação para construção de Centro Educacional}

A ação analisada tramitou perante a $11^{\mathrm{a}}$ Vara da Fazenda Pública de São Paulo/SP, processo n. ${ }^{o}$ 583.53.2002.02.022350-9, tendo como proprietário o Município de São Paulo e proprietário a Cerâmica São Caetano. Imóvel: Rua Barbinos, s/n. ${ }^{\circ}$ e 111; Finalidade: utilidade pública - construção de um Centro Educacional Unificado - CEU, Decreto Municipal n. ${ }^{\circ} 42.025$ de 20 de maio de 2002; área total 31.899,03 m²; desapropriação total. 
O Município ofereceu o valor de $\mathrm{R} \$ 1.431 .122,53$ quando ingressou com ação judicial, mas o juiz entendeu ser necessária a prévia avaliação do imóvel.

Em contestação a proprietária requereu a justa indenização, nos termos do art. $5^{\circ}$, XXIV da Constituição Federal, acrescida de juros compensatórios de 12\% a.a., a partir da imissão prévia na posse e juros moratórios fixados no percentual de $6 \%$ a.a. contados do trânsito em julgado da sentença sobre o valor indenizatório, inclusive sobre juros compensatórios.

O laudo provisório realizado em 26de setembro de 2002 utilizou as "Normas para Avaliação de Imóveis Urbanos" e publicação "Valores de Edificação de Imóveis Urbanos", 2002, ambas do IBAPE. Foi utilizado o método involutivo em que se projetaram as rendas que a proprietária obteria se urbanizasse a gleba, descontando-se os custos com a urbanização. O valor da indenização foi calculado em R \$ 3.153.690,00.

Em 06 de dezembro de 2002 houve imissão na posse por parte do Município para dar início às obras do centro educacional. O laudo definitivo de 04de julho de 2003 não revelou grandes alterações de valores, concluindo-se pela indenização de R \$ 3.154.794,00.

Em 23de julho de 2003 a proprietária concordou com o laudo do perito, mas solicitou atualização do valor da indenização para o mês de julho de 2003, com base nos Índices de Preços ao Consumidor (Índices de Custo de Vida), o que resultou nos valores de R\$ 3.721.900,00. O Município de São Paulo não concordou com a avaliação seus peritos calcularam o valor de indenização em $\mathrm{R}$ 2.156.420,64.

Em sentença de 18de maio de 2004 a indenização foi fixada em R 3.154.794,00 para setembro de 2002, com incidência de correção monetária judicial sobre o valor da avaliação, com base na Tabela do TJ, a partir da data base da avaliação (setembro de 2002) 
até efetivo pagamento, mais incidência de juros compensatórios de $12 \%$ a.a. a partir da imissão da posse e juros moratórios de $6 \%$ a.a., desde a data do trânsito em julgado, a serem calculados sobre total da avaliação devidamente atualizados até o efetivo pagamento, integrando-se os eventuais compensatórios à base do cálculo dos moratórios (Súmula 102 STJ). Portanto, os juros devem ser calculados cumulativamente sobre a diferença entre o valor atualizado da oferta e o valor atualizado da indenização até o efetivo pagamento.

Diante da elevada divergência entre os laudos, em 22de junho de 2004, o Município de São Paulo recorreu pleiteando a redução da indenização para R $2.156 .420,64$ para junho de 2002, pois ao fixar a indenização o juiz não levou em conta as considerações do assistente técnico. O Tribunal não deu razão ao recurso do Município de São Paulo e manteve a indenização fixada na sentença do juiz de primeiro grau.

O processo estudado revela uma grande disparidade entre os laudos realizados pela comissão de peritos e o do perito do Município, fato que revela a ausência de parâmetros claros na legislação a fim de se avaliar imóveis para fins de desapropriação.

O Município, por sua vez, não faz menção aos seus planos urbanísticos para a cidade e nem se o imóvel cumpre a função social prevista para ele no plano diretor.

\section{VI - Desapropriação para construção de Centro Educacional}

A ação analisada tramitou perante a $7^{\circ}$ Vara da Fazenda Pública de São Paulo/SP, processo n. ${ }^{o}$ 583.53.2006.107734-5, tendo como expropriante o Município de São Paulo, e proprietários Melgaço Paschoal e Maria de Lourdes de Oliveira Santos Paschoal. Imóvel: Avenida Engenheiro Armando de Arruda Pereira, ns. ${ }^{\circ}$ 5241, 5255, 5265 e 5275, e lote 8 quadra 1; Rua Frei Antonio Brandão quadra 1 lotes 1 a 4, quadra 2 lotes 1 a 8; quadra 3 lote 1; 
Rua Ulisses Paschoal quadra 1 lotes 5 e 7; quadra 2 lotes 10 e 11; Rua Luiz Augusto Paschoal quadra 2 lote 9; área com 33.476,82 m².

O imóvel foi declarado de utilidade pública pelo Decreto Municipal n. ${ }^{\circ} 43.162$ de 12 de maio de 2003, para a construção de um Centro Educacional.

O Município requereu a desapropriação oferecendo o valor de $\mathrm{R} \$ 2.361 .408,16$. Salientou ter urgência na desapropriação.

O laudo provisório foi realizado em 22de novembro de 2006 e salientou que o imóvel é constituído de duas partes distintas: uma gleba localizada à Av. Engenheiro Armando Arruda Pereira, n. ${ }^{\circ} 5241$ e 5275 e diversos lotes localizados à Rua Frei Antonio Brandão, Rua Ulisses Paschoal e Rua Luiz Augusto Paschoal. O laudo também informa que, segundo a lei de zoneamento, a gleba se enquadra na zona especial de interesse social e os lotes na zona mista de densidade demográfica e construtiva baixa.

O critério de avaliação adotado foi a utilização das normas para avaliação de imóveis da Vara da Fazenda Pública de São Paulo "Normas CAJUFA 2004”. Para caso de desapropriação parcial será adotado o critério metro quadrado médio do terreno original e para a gleba adotar-se-á o método involutivo, pois não é possível o método comparativo em razão da falta de áreas similares. Atribuiu-se à totalidade da área o valor de indenização de R \$ 4.055.254,00.

As partes fizeram um acordo e os proprietários autorizaram a ocupação amigável da requerente em 27de março de 2007. O juiz autorizou a imissão na posse na data acima e determinou a complementação do depósito, determinando a intimação do perito para elaboração de laudo definitivo. 
O processo ainda não está encerrado, mas as diferenças entre os valores oferecidos inicialmente pelo Município e os apurados pelo laudo provisório são consideráveis.

Também é importante destacar que parte da área é prevista pelo plano diretor como sendo zona de interesse social, o que permite seu uso apenas para habitações de interesse social para a população de baixa renda. Este dado influi no preço da terra e não foi considerado pelos peritos em laudo provisório.

\section{VII - Desapropriação de área para expansão de linha de Metrô}

A ação analisada tramitou a $10^{\mathrm{a}}$ Vara da Fazenda Pública de São Paulo/SP, processo n. ${ }^{\circ}$ 583.53.2004.004600-9, tendo como expropriante a Companhia do Metropolitano de São Paulo, e proprietários Nelly Mahfuz Amatti. Imóvel: Rua Breno Ferraz do Amaral, n. ${ }^{\text {o }}$ 495; área 5.447, $48 \mathrm{~m}^{2}$.

O imóvel foi declarado de utilidade pública pelo Decreto Estadual n. ${ }^{\circ} 48.473$ de 28/ de janeiro de 2004 para ampliação da rede de Metrô na cidade de São Paulo. A Companhia do Metropolitano requereu a desapropriação oferecendo o valor de $\mathrm{R} \$$ 1.582.089,00. Salientou ter urgência na desapropriação.

O laudo provisório foi realizado em 26de agosto de 2004 e informa que a lei de zoneamento do Município classifica o imóvel como predominantemente residencial de densidade demográfica baixa. O valor unitário do terreno foi calculado com base na Portaria CAJUFA, $n^{\circ} .2 / 04$, atualizado para junho de 2004. Atribuiu-se o valor de R\$ 5.305.867,53 à indenização e a Companhia do Metropolitano obteve a imissão na posse em 09 de setembro de 2004. 
O laudo definitivo foi realizado em 19 de abril de 2007 e alterou o valor da indenização para R $\$ 5.771 .786,28$.

Os proprietários se manifestaram sustentando ser irrisório o valor unitário e requereu segunda perícia. A data base deve ser a de abril de 2007, data de apresentação do laudo. Os elementos comparativos que compõem o estudo da CAJUFA datam de março de 2004, ou seja, com três anos de diferença em relação ao mês abril de 2007, data da apresentação do laudo. O valor unitário deverá ser de R \$ 900,00/m². Houve concordância com o valor apresentado a título de benfeitorias. Valor total da indenização R \$ 7.642.181,73.

No referido caso também se verifica a grande divergência entre os valores dos laudos realizados até o momento e os proprietários requerem nova perícia. Entendemos que no caso de áreas maiores, em que o método comparativo não pode ser aplicado, as avaliações realizadas partem de hipóteses diversas e os resultados apresentados para o cálculo das indenizações são sempre muito discrepantes.

\section{VIII - Desapropriação de área para expansão de linha de Metrô}

A ação analisada tramitou perante a $13^{\circ}$ Vara da Fazenda Pública de São Paulo/SP, processo n. ${ }^{\circ}$ 583.53.2004.022261-4, tendo como expropriante a Companhia do Metropolitano de São Paulo, requerido: Condomínio Edifício Passarelli e Construtora Passarelli S/A. Imóvel: - Avenida Paes Leme, n. ${ }^{\circ}$ 524; área com 1.807,28 m².

O imóvel foi declarado de utilidade pública pelo Decreto Estadual n. 46.230 de 30 de outubro de 2001 para ampliação da linha do Metrô na cidade de São Paulo. A Companhia do Metropolitano ocupou temporariamente área $892,61 \mathrm{~m}^{2}$ e requereu a desapropriação oferecendo o valor de R \$ 2.398.200,00. Salientou ter urgência na desapropriação. 
O laudo provisório foi realizado em 14 de outubro de 2005 para avaliar a porção de terreno a ser destacada da gleba matriz do expropriado, retirada do interior do imóvel sem alcançar os seus limites externos área desapropriada de $1.807,28 \mathrm{~m}^{2}$ e de $892,16 \mathrm{~m}^{2}$, com mesmas características, destinadas à ocupação temporária.

Localizadas no setor fiscal 083, quadra 99, conta com frente para Rua Paes Leme, Av. Nações Unidas e Rua Capri. O laudo informa que pela Lei de Zoneamento do Município de São Paulo, a área é classificada como predominantemente residencial e densidade demográfica baixa.

Como a desapropriação afetará a área de estacionamento, entende que o expropriante deverá arcar com o custo correspondente à locação de número igual as que restaram indisponíveis durante o período em que perdurar a ocupação temporária e responder pelas vagas irremediavelmente perdidas com a desocupação.

As normas utilizadas são para avaliação de imóveis das varas da Fazenda Pública (CAJUFA/2004).

O critério recomendado pelas normas CAJUFA 2004 é do metro quadrado médio do lote primitivo. Se a porção remanescente do terreno passar a valer menos por metro quadrado que na situação anterior, substituir-se-á o critério inicial pelo método "antes e depois", que traz embutido em seu bojo a desvalorização da área remanescente. O laudo provisório fixou em $\mathrm{R} \$ 6.104 .294,00$.

O proprietário, em contestação, requereu seja fixada indenização com base no preceito constitucional do justo valor indenizatória e, para imissão na posse, ressalvou a importância da avaliação prévia e do depósito provisório. Requereu também juros compostos de $12 \%$ ao ano, incidente sobre a diferença entre a oferta inicial e a indenização fixada, 
ambas corrigidas a partir da prévia imissão na posse, cumulativamente com juros moratórios de $6 \%$ ao ano, a partir do trânsito em julgado, incidente sobre a diferença entre a oferta inicial e a indenização corrigida e acrescidos de juros compensatórios, conforme Súmula 102 STJ, honorários sobre a diferença entre a oferta inicial e a indenização final corrigidos e acrescidos de juros compensatórios (131 STJ), custas e despesas processuais.

Foi determinada a imissão na posse em 22 de novembro de 2005. O laudo definitivo foi realizado em 24 de novembro de 2006 e, considerando os mesmos fatores do laudo realizado a título provisório fixou o valor da indenização em $\mathrm{R}$ \$ 7.352.115,00.

Os proprietários divergem dos fatores adotados pelos peritos nomeados pelo juiz e requerem a fixação da indenização $\mathrm{R}$ \$ 8.231.141,00. Também a expropriante discorda dos valores apresentados pelos peritos do juiz. Em última manifestação do processo o perito nomeado pelo juiz concordou com o expropriante e reduziu a indenização para $\mathrm{R} \$$ 7.334.539,00 para novembro de 2006.

No caso analisado o processo ainda não está terminado, mas também revela a dificuldade da avaliação de imóveis desapropriados. A divergência entre os valores apresentados também é grande neste caso, e não foi considerada a valorização que será acrescentada ao condomínio proprietário após a conclusão das obras da estação do Metrô.

\section{IX - Desapropriação de área para expansão de linha de Metrô}

A ação analisada tramitou perante a $12^{\mathrm{a}}$ Vara da Fazenda Pública de São Paulo/SP, processo n. ${ }^{\circ}$ 583.53.2001.020568-4, tendo como expropriante o Município de São Paulo, e proprietários Luiz Ozores Troncoso, Therezinha Setti Ozores, Danilo Adelelmo Setti e Rosalie Setti. Imóveis: - Rua Arvoreiro, s/n e Rua Domingos Tarroso, s/n. 
O imóvel urbano foi desapropriado por utilidade pública para a construção de um Centro Educacional Unificado - CEU, Decreto Municipal n. 36.914 de 13 de junho de 1997; área total $14.406,60 \mathrm{~m}^{2}$; desapropriação total.

Neste processo judicial o valor de $\mathrm{R} \$ 733.211,83$, oferecido pelo Município de São Paulo, não foi aceito pelos proprietários, posto que considerado muito baixo. Como os proprietários não aceitaram os valores ofertados pelo Município, o juiz determinou a avaliação prévia do imóvel e os proprietários, em defesa, solicitaram a aplicação de juros de justa indenização.

O laudo provisório de 14 de dezembro de 2001 avaliou os terrenos, todos em área urbana, bem como os muros construídos para seu fechamento, atribuindo-lhe o valor de R\$ $2.962 .315,00$.

O Município se manifestou alegando que o perito não apresentou a pesquisa que deu origem ao valor unitário do terreno. Sustenta que o perito utilizou incorretamente o mesmo valor unitário do terreno para lote padrão e para gleba, quando o valor unitário de terreno da gleba é inferior ao das outras áreas.

O perito informou que a pesquisa de preço unitário do terreno não foi anexada a pesquisa por tratar-se de laudo prévio, quanto a adoção de um procedimento diferenciado para avaliação da Gleba 1 e das demais áreas não pode prosperar, pois integram a mesma quadra fiscal e apresentam as mesmas características, mas retifica uma das pesquisas e reduz a indenização para $\mathrm{R} \$ 2.774 .865,00$.

O laudo definitivo confeccionado em 14 de junho de 2003, quase dois anos depois, mantém as mesmas premissas do laudo prévio e aumenta o valor da avaliação para $\mathrm{R} \$$ 2.903.802,00. 
Os proprietários manifestaram concordância com o laudo pericial, mas o Município não. Segundo o Município a área deveria ter sido avaliada como gleba e não lote, além de não ser o caso de se aplicar o método comparativo e sim o evolutivo, oferecendo como indenização o valor de R\$1.233.630,00 para o mês julho de 2003 .

Em Sentença, na data de 25 de junho de 2004, um ano depois, o juiz fixou a indenização em R\$ 2.903.802,00, corrigido pelo índice IPC do FIPE, a partir da data da feitura do laudo, julho de 2003, mais a aplicação de juros moratórios de $6 \%$ a.a. a contar do trânsito em julgado da sentença, mais custas e honorários de 7\%, calculados sobre a diferença entre o valor da oferta e o valor encontrado no laudo definitivo.

O Município recorreu em 09 de novembro de 2004 pedindo redução da indenização, pois ao fixar a indenização o juiz não levou em conta as considerações de seu assistente técnico.

Em 04 de setembro de 2006 o Tribunal de Justiça de São Paulo corrigiu o laudo sob o fundamento de que houve engano dos peritos ao deixar de aplicar o fator desvalorizante da topografia, porquanto os terrenos eram em aclive, perto de $3 \mathrm{~m}$ acima do nível das ruas públicas. Assim a terra nua comporta redução de $10 \%=\mathrm{R} \$ 285.358,00$.

Neste caso, o Município ingressou no imóvel em 2 de março de 2006 por meio de autorização para ocupação imediata e entrega das chaves do imóvel, antes da decisão final do processo, mediante o depósito do laudo prévio, e, como nos casos anteriores, apresenta os mesmos problemas avaliatórios, ou seja, ausência de uniformidade nas regras utilizadas para avaliação e ausência de análise das leis urbanísticas que descrevem a destinação da área. 


\subsection{Conclusão}

A fixação do valor de indenização em desapropriação possui etapas. Apurado o valor principal, corrige-se monetariamente, aplicam-se os juros compensatórios, que vem sendo fixado entre $6 \%$ a $12 \%$, a critério do Juiz, tendo como termo inicial a imissão de posse ou ocupação da área por parte do Poder Público e final com a expedição do precatório. Quanto aos juros moratórios, sua incidência ocorre a partir do trânsito em julgado e, em alguns novos julgamentos, tem-se entendido que apenas é cabível após o atraso do pagamento por parte da Administração Pública, ou seja, são devidos a partir do exercício seguinte àquele em que deveria estar previsto no orçamento público.

Também destacamos que a aplicação dos juros compensatórios tem grande relação com o laudo de avaliação, especificamente, quanto ao método de avaliação adotado. Em nosso entendimento, qualquer laudo que trabalhe com hipóteses sobre os ganhos que a propriedade poderia produzir, já incorpora a idéia dos juros compensatórios. Deste modo, ao se considerar, no laudo, os prejuízos do proprietário e a renda que ela deixará de auferir, ilegítima será a incidência de juros compensatórios sobre este montante. Continuar essa prática é permitir indenizar duplamente o proprietário.

Em razão disso, não deve o juiz adotar o laudo sem entender os princípios que o fundamentaram. Ao entender o método adotado, o juiz, se for o caso, exclui a incidência dos juros compensatórios.

Relativamente aos casos pesquisados junto às Varas da Fazenda Pública da Comarca de São Paulo, o objetivo foi o de verificar se o valor auferido tanto na avaliação prévia quanto na avaliação definitiva refletia um valor justo, que considerasse princípios 
informadores do direito urbanístico, como a recuperação da mais valia a aplicação da função social da propriedade e de justiça social.

Os casos selecionados ilustram os problemas do procedimento da desapropriação no Brasil. Foram realizadas perícias com base em critérios discutidos por um grupo criado junto ao Poder Judiciário, mas estes critérios não têm nenhum parâmetro previsto em lei, o que gera insegurança, pois nada impede que sejam modificados conforme se altere a composição dos membros que compõem o grupo de estudos. Além disso, como os critérios utilizados nem sempre são uniformes, as divergências apresentadas nos laudos no que se refere aos valores de indenização são consideráveis, principalmente nos casos de áreas maiores.

Um dos casos escolhidos para análise retrata que é o perito quem decide se houve ou não ganho de mais valia por parte do proprietário, muito embora o juiz não tenha se pronunciado sobre a análise do perito, situação que corrobora o problema da ausência de critérios legais a ser seguido pelas perícias, pois muitas vezes peritos interpretam normas sem a participação dos juízes, os quais apenas acatam os laudos.

Aliás, em todos os casos estudados, verifica-se que o Juiz acata o laudo sem questionar seus resultados, situação que em um passado recente gerou indenizações milionárias e que são impasse para pagamento até os dias de hoje. Tal fato pode ser constatado inclusive nas decisões dos recursos, pois o próprio Tribunal questiona os critérios utilizados pela CAJUFA.

Os casos também demonstram que mesmo com a iniciativa judicial em determinar que o pagamento não seja tão demorado para o proprietário, em alguns casos, uma das partes 
não fica satisfeita com o valor fixado no laudo inicial, o que torna a processo demorado em razão da interposição de recursos pela parte insatisfeita.

Nos casos analisados, não foi possível verificar a hipótese de desapropriação por descumprimento da função social da propriedade urbana, pois o Município de São Paulo, ainda não iniciou o procedimento que poderia tornar legal está espécie de desapropriação prevista na legislação, que origina com a notificação aos proprietários para adequarem as propriedades ao estabelecido nos planos.

Além disso, o instrumento da desapropriação é utilizado de forma muito tradicional, não sendo combinada com outros instrumentos os quais poderiam tornar efetiva a captura de mais valias oriunda das obras que serão realizadas, sobretudo com as realizadas pelo Metrô. Instrumentos como a outorga onerosa ou a transferência do potencial de construir poderiam ser alternativas ou combinações interessantes a serem utilizadas pelos proprietários em outras áreas da cidade.

Com efeito, verificamos que a avaliação é exclusivamente realizada com base em normas técnicas, baseadas em critérios que objetivam assegurar que a propriedade tenha seu valor atribuído pelo preço de mercado.

Nos casos analisados, verificamos que as pequenas propriedades são avaliadas e, fixado e depositado o preço, o processo se encerra sem discussão de quaisquer das partes.

Nas propriedades maiores, mesmo com o depósito prévio, sempre há recursos, questionando não só os critérios técnicos do laudo, como a incidência dos juros compensatórios. 
O Tribunal de São Paulo não reduz a taxa de juros compensatórios, mas chegou a reduzir o valor do laudo por não concordar com o critério técnico adotado pelo perito, indiciando que a adoção de critérios de avaliação ainda é muito polêmica, não sendo pacificada pela criação do CAJUFA (Processo n. ${ }^{\circ} 583.53 .2001 .020568-4,12^{\mathrm{a}}$ Vara da Fazenda Pública de São Paulo/SP, requerente: Município de São Paulo).

As regras fixadas pela comissão de peritos da Justiça de São Paulo foram mais adequadas nas avaliações de pequenas áreas. Em geral, quando não é possível utilizar o método comparativo e o método é baseado em hipóteses sobre a rentabilidade do imóvel, as divergências entre os valores de indenização são muito grandes.

Acreditamos que referidas divergências poderão ser diminuídas quando lei vier estabelecer critérios mais objetivos e uniformes para a avaliação de lotes e glebas urbanas, obrigando os peritos a considerarem as legislações urbanísticas que incidem sobre o imóvel avaliado.

Também é importante que o Poder Público possua um atualizado cadastro imobiliário para fins fiscais. Nos processos pesquisados verificamos que os valores fiscais dos imóveis desapropriados são muito defasados em relação aos valores de mercado dos imóveis, o que dificulta a possibilidade haver acordo preliminar com os proprietários quando o Poder Público decide desapropriar.

A captura das mais valias acrescentadas às propriedades em função dos melhoramentos e obras públicas realizadas no entorno das propriedades é praticamente inexistente.

Os procedimentos adotados pela Justiça de São Paulo nos processos de desapropriações possibilitam que muitos processos se encerrem com mais agilidade, pois, 
principalmente nos casos em que se desapropriam pequenas propriedades ou nos casos em que a Companhia do Metrô tem interesse, as partes aceitam os valores fixados nos laudos com base nos critérios estabelecidos pelo CAJUFA, o que sem dúvida também beneficia os cofres públicos em função de não incidir juros moratórios e compensatórios, que somados, aumentam a indenização em $18 \%$ ao ano.

Essa prática tenta realizar uma desapropriação amigável, fixando, desde o início do processo, o valor a ser pago ao proprietário, minimizando os efeitos da interferência estatal na propriedade privada, o que demonstra que um dos problemas da desapropriação no Brasil é a incapacidade da Administração Pública em realizar a desapropriação amigável, necessitando da interferência judicial.

A análise dos dados nos permitiu concluir que o Brasil necessita de lei que uniformize os critérios para avaliações em desapropriações, sobretudo nas de cunho urbanístico e ambiental, a fim relacionar a avaliação diretamente aos princípios da função social da propriedade e da justa indenização, sem prejuízo de tomada de nova posição por parte dos poderes públicos para adotarem outros instrumentos urbanísticos para a captura de mais valias das áreas valorizadas por melhoramentos públicos.

Como o procedimento da CAJUFA não é estabelecido em lei, sua adoção é mais suscetível a sofrer modificações por parte dos tribunais superiores, que podem rever os casos em que foi aplicado.

Em conclusão, o depósito prévio soluciona parte dos problemas das indenizações, pois reduz o decurso de prazo de incidência dos juros. Porém, para as grandes áreas, os critérios técnicos adotados pelo CAJUFA necessitam se ajustar aos novos conceitos urbanísticos que fazem parte do direito brasileiro. 
Contudo, muito embora este procedimento não possa sanar as causas das indenizações elevadas, pois a ausência de critérios legais nas perícias pode propiciar o retorno desta conduta, o procedimento do Poder Judiciário da Comarca de São Paulo tem fundamental importância ao propiciar que a desapropriação se resolva por acordo, no início do processo judicial. 


\section{Capítulo 7}

\section{TEMAS E INSTRUMENTOS JURÍDICOS QUE MUDAM A PERSPECTIVA DA DESAPROPRIAÇÃO}

A partir da ordem social, urbanística, ambiental e econômica desenhada com a Constituição Federal de 1988, alguns temas e instrumentos urbanísticos podem atribuir à desapropriação uma nova perspectiva, independentemente de uma nova legislação que a compatibilize com essa ordem.

\subsection{Valorações econômicas de recursos ambientais}

As unidades de conservação ${ }^{63}$ em suas diversas modalidades, tais como parques, estações ecológicas e áreas de proteção ambiental foram criadas, nos últimos anos, observando-se aspectos relacionados à riqueza biológica.

Ressalte-se que a aplicação de instrumentos econômicos não era ainda o foco de atenção por parte dos formuladores e executores de políticas ambientais.

Como conseqüência dessa omissão, as áreas protegidas foram criadas no contexto legal, mas, sem serem submetidas a uma avaliação econômica e muito menos a uma mensuração dos custos diretos e indiretos, e dos benefícios que estas áreas podem oferecer para a sociedade. Portanto, no passado, a análise de custo-benefício foi negligenciada na política de gestão de áreas protegidas do Brasil; entretanto, nos últimos anos, surgiram algumas experiências no país.

\footnotetext{
63 Unidades de conservação são espaços ambientais que têm importantes características naturais e são legalmente instituídos pelo Poder Público com objetivos de conservação. Possuem limites definidos e existem sob um regime especial de administração, ao qual se aplicam garantias adequadas de proteção. Ou seja, são as reservas biológicas, parques e estações ecológicas que nós conhecemos ou pelo menos já ouvimos falar.
} 
A análise de custo-benefício parte do pressuposto de que todo recurso ambiental possui uma função econômica relevante, e pode ser considerado como um exemplo clássico de bem ou serviço que não é transacionado no mercado, e como não possui preço definido, é indispensável o uso de métodos indiretos de valoração econômica como, por exemplo, no caso de fixação do valor recreativo de um parque.

Como afirmamos, nos casos em que há interesse na conservação de parcelas desses recursos, as tomadas de decisão normalmente levam em consideração critérios ambientais, biológicos e geográficos. Entretanto, a utilização complementar de um critério econômico pode aumentar a eficiência da gestão ambiental, reforçando sua dimensão humana. (MOTTA, 1998).

Os fundamentos da teoria econômica de áreas protegidas estão baseados na escola da economia do bem estar, "welfare economics", de inspiração neoclássica, assumindo a hipótese das dádivas gratuitas e de livre disposição de dejetos do sistema econômico, e, gradualmente, passa a tratar a economia como um sistema isolado. Vale dizer que até recentemente a teoria econômica deixava em plano muito secundário a análise das interrelações entre o sistema econômico e o meio ambiente. A evolução da incorporação da dimensão ambiental à análise econômica se deveu principalmente a três fatos: "a intensificação da poluição nas economias industrializadas; os choques do petróleo da década de 1970; e a publicação, em 1972, do relatório do Clube de Roma", segundo o mesmo autor.

No que se refere à capacidade de fornecer instrumentos operacionais para o tratamento de problemas concretos, a economia ambiental neoclássica tem-se destacado, como é o caso da valoração econômica de áreas protegidas, onde os componentes do ecossistema são considerados de forma distinta, entre recursos de uso direto, de uso indireto, de opção e de não-uso (ou valor de existência). 
Considera-se como valor de uso direto a utilização atual do recurso ambiental através de uma atividade de produção ou consumo direto como, por exemplo, através da extração de recursos ou da visitação. Quanto ao valor de uso indireto, este é derivado das funções do ecossistema como proteção do solo, estabilidade climática, preservação de mananciais, etc. O valor de opção é aquele em que o indivíduo atribui valor em usos diretos e indiretos, que poderão ser optados futuramente e cuja preservação pode estar ameaçada, como a biodiversidade.

E, finalmente, o valor de existência é um valor dissociado do uso, derivado de uma posição moral, cultural, ética ou altruística em relação à preservação das riquezas naturais e de outras espécies, mesmo que elas não representem nenhum uso futuro, como o lazer de um parque. Um indivíduo pode não freqüentá-lo por preferir se utilizar de um clube particular do qual é sócio, mas está disposto a pagar pela sua existência para que outros possam dele usufruir.

Nem todos esses valores são hoje considerados, pois as políticas públicas de conservação ambiental têm considerado apenas o custo do valor de uso direto, o que limita significativamente o valor econômico das Unidades de Conservação. Sua utilidade como fator de estabilidade climática e de conservação da biodiversidade e do solo, mesmo sendo motivo de preocupação implícita, não são valorados, subestimando o seu valor econômico total.

O problema, quando não se mensura os benefícios, é geralmente a sua subestimação, ou seja, seus valores não são considerados, e por isso não podem se contrapor aos custos imediatos associados com a implantação e manutenção das áreas protegidas. Assim, o comportamento da Administração Pública geralmente tem sido o de levar em conta o custo de oportunidade ao não desenvolverem as terras para outros fins, e o custo de manejo, da manutenção e da infra-estrutura. 
Como os custos são muito elevados face aos benefícios incertos que se podem obter, somando-se a outros fatores, como um crescimento populacional intensivo, ocupação desordenada do solo, usos conflitantes do solo, desemprego, políticas de manejo de recursos naturais distorcidas e informação inadequada, há a possibilidade de ocorrência de uma série de ameaças ao futuro dos parques nacionais e estaduais, como os da Serra do Mar, cuja discussão judicial ainda pode demorar alguns anos relativamente ao valor que deverá ser indenizado.

A atribuição do valor econômico aos benefícios gerados pela conservação facilita a tomada de decisões em políticas públicas, e pode representar um importante aliado para o órgão gestor ambiental no momento da proposição de criação de novas áreas para conservação, de forma a não repetir falhas de governo como a de criar novas Unidades de Conservação sem uma análise custo-benefício. Isso, sem se levar em consideração os casos em que no ato de criação de áreas protegidas não contempla sequer recursos financeiros para indenização, nos casos em que sua criação implicar impedimentos à utilização da propriedade.

O uso da técnica da análise custo-benefício no contexto da política de conservação estadual e nacional possibilitaria viabilidade econômica de áreas protegidas, através da definição de estratégias da maximização dos benefícios sociais de tais áreas, proporcionando gerar renda e empregos com o uso sustentável dos recursos naturais, além de se evitar custos demasiados com processos judiciais, em que não é possível determinar com precisão qual será o custo dessas áreas.

No entanto, esses conceitos da economia devem ser mediados com os conceitos provindos da ecologia, para que de fato haja desenvolvimento sustentável. As teorias econômicas são modelos que precisam ser contextualizados, sobretudo porque a proposta básica da economia ambiental e a valorização monetária da natureza, requerem artifícios, ou 
seja, não correspondem às forças do mercado, que as emprega necessariamente como bem livre ou em abundância, necessitando de amparo jurídico e político, a fim de alcançar o escopo almejado.

Nesse sentido Derani (1997, p. 127)

Tomando-se as contribuições da economia ambiental, sem fechar os olhos a suas limitações; verificando-se, mais detidamente, que o conflito sobre o qual ela trabalha, é conflito imerso na visão restrita e incorreta de que todos os elementos da produção podem ser inseridos na dinâmica reguladora do mercado marketable good é forçoso admitir que cabe à aplicação do direito a "justa medida", na composição destas teorias, contextualizando e adaptando-as às condições e exigências sociais e sobretudo ratificando a complexidade - jamais oposição - da relação entre economia e ecologia. (...)

Torna-se imprescindível, destarte, situar como o direito age na mudança de perspectiva da apropriação dos recursos naturais para o desenvolvimento econômico. $\mathrm{Ou}$ - o que também remete ao direito - investigar de que modo a prática econômica deve se desenvolver, para que não mine os fatores que a sustentam.

Acrescente-se que instrumentos de participação direta da sociedade serão necessários nesse processo, pois só a participação concreta dos cidadãos poderá equilibrar as forças entre Estado e Mercado, a fim de que se garanta o bem-estar social tendo em vista também os interesses das comunidades envolvidas.

\subsection{As experiências da Colômbia e do Brasil}

Há um crescente interesse na utilização de novas metodologias de valoração de propriedades, conceituadas no âmbito da Economia Ambiental, incorporando valores que são intangíveis, ou seja, que pela sua natureza não se expressam através do mercado. A aplicação de tais técnicas, já utilizadas em outros países, tem sido tema de um grande número de trabalhos em revistas científicas especializadas, em especial do Journal of Environmental Economics and Management, editada pela Association of Environmental and Resource Economics. Registram-se fóruns eletrônicos internacionais que ativamente discutem o tema, 
entre os quais a Sociedad Científica del Valor, pertencente à Sociedad Colombiana de Economistas.

No Brasil, estudos sobre a valoração de bens de interesse ambiental têm sido feitos e discutidos nos Encontros da Sociedade Brasileira de Economia Ecológica. No entanto, este conhecimento e, em particular, seus métodos, ainda não foram reconhecidos no nosso meio de avaliações, e seu uso nos processos judiciais é praticamente inexistente.

Contudo, importante destacar a decisão do último Congresso da União Panamericana de Associações de Avaliação (UPAV), que, por seus delegados reunidos no Hotel Gran Marquise Sol Meliá de Fortaleza, Estado do Ceará, República Federativa do Brasil, por ocasião do XXII Congresso Panamericano de Avaliações, organizado pelo Instituto Brasileiro de Avaliações e Perícias de Engenharia (IBAPE), deliberou colocar em sua Carta que "o valor de um bem depende da finalidade da avaliação e da definição aplicável para o caso específico em análise, no momento estabelecido para o trabalho avaliatório” ${ }^{64}$ Referida recomendação, embora não seja texto de lei, orienta os avaliadores a mudarem o paradigma anteriormente utilizado nas avaliações segundo o qual "o valor de um imóvel em um dado momento é único, quaisquer que sejam os fins para os quais ele é usado".

Esta importante mudança poderá repercutir beneficamente nas avaliações atuais, possibilitando tratamentos mais próprios ao contexto de desapropriação. A avaliação conhecida por "não mercado" (sic) de bens recebeu consideração específica na última edição das normas do International Valuation Standards Committe - IVSC, divulgadas em 2005, em particular da sua “Norma Internacional de Valuación - NIV 2-” Bases de valuación distintas al valor de mercado", em vigor desde julio de 2001, e do correspondente guia: "Guidance

\footnotetext{
${ }^{64}$ Ver íntegra da Declaração de Fortaleza no site: http://www.ctageo.com.br/upav_pt.html
} 
notes: valuation of intangible assets”, disponível em sua página de Internet, o que, espera-se estimular sua adoção nos países participantes do Comitê.

Proposta interessante foi desenvolvida pela Alcadia Mayor, Prefeitura, de Bogotá, na Colômbia, através de seu Departamento Técnico Administrativo del Médio Ambiente DAMA, e coordenado pelo Engenheiro Oscar Borrero Ochoa ${ }^{65}$, a qual partindo de regularidades estatísticas atribui valor aos chamados "serviços ambientais" prestados pela cobertura vegetal da áreas protegidas, sendo quatro deles os principais:

a) demanda por recursos hídricos;

b) demanda por terra vegetal e controle da erosão;

c) manutenção da biodiversidade em bosques naturais;

(d) seqüestro do $\mathrm{CO}_{2}$ e produção de oxigênio pela cobertura vegetal.

Interessante nesta proposta é que ela indica o estabelecimento de limite de valor superior - um teto - que é relacionado a um limite inferior, que seria em princípio, o valor da terra para fins agrícolas. A partir deste valor básico são acrescidas parcelas de valor correspondente a cada um destes serviços ambientais. A aplicação desta metodologia requer do perito ambiental conhecimento de temas ecológicos e biodiversidade, ou contar com assessoria especializada.

Destacamos que o Ministério Ambiente do Brasil fez estudo, consubstanciado em manual, que orienta o emprego de diversos métodos que podem ser utilizados para valoração

${ }^{65}$ Em seminário realizado na Colômbia em 2005 o engenheiro colombiano criticou o método de avaliação contingente por ser de difícil aplicação matemática e apresentou a proposta de Bogotá: "DAMA tiene una propuesta basada en El Valor agrícola más mejoras ambientales por puntaje. El. valor agrícola por analogía es el PISO del avalúo".Ver apresentação em:

www.territorioysuelo.org/.../Presentaciones_foros/2005/Seminario_recuperacion_de_plusvalias/01_O_Borrero.p df 
econômica de recursos naturais ${ }^{66}$. Este trabalho também apresenta alguns casos em que esses métodos foram utilizados, no Brasil e em outros diversos países.

O primeiro caso é um estudo realizado para o Programa de Despoluição da Bacia de Guanabara no Rio de Janeiro. ${ }^{67} \mathrm{O}$ estudo teve como objetivo a análise de custo benefício da intervenção, que, conforme definição do Ministério do Meio Ambiente consiste na técnica econômica mais utilizada para a determinação de prioridades na avaliação de políticas. Seu objetivo é comparar custos e benefícios associados aos impactos das estratégias alternativas de políticas em termos de seus valores monetários.

O segundo caso foi o estudo realizado para medir as mudanças ambientais no Pantanal, Brasil. ${ }^{68} \mathrm{O}$ objetivo do estudo foi o de estimar o benefício ambiental e o interesse da pesquisa resume-se no estudo da aplicação do método de valoração contingente no Brasil e em verificar os problemas específicos de amostragem e veículos de pagamento.

Com efeito, é importante para avaliação de áreas que serão objeto de desapropriação uma maior aproximação das teorias econômicas, a fim de dar-lhes um maior fundamento. Os valores econômicos derivam do conceito fundamental da disposição de pagar do consumidor por um determinado bem ou um serviço específico, considerando-se o variável tempo e lugar.

Atualmente, há um aumento da literatura da teoria econômica que se ocupa da valoração de serviços ambientais e dos bens comerciais associados com bosques, florestas tropicais e zonas pantanosas.

\footnotetext{
${ }^{66}$ Consultar : http://www.mma.gov.br/biodiversidade/publica/mvalora/man0213.html

${ }^{67}$ Este estudo de caso é parte do projeto de tese de Carolina B. S. Dubeux na COPE/UFRJ no Programa de Planejamento Ambiental.

${ }^{68}$ Analisado por Ronaldo Serôa da Motta
} 
No entanto, há poucos exemplos sobre a prática desses métodos. E isso não ocorre por falta de métodos teóricos e sim sobre uma carência de dados sobre as funções da produção de bens ambientais, bem como pela ausência de acordo adequada sobre os critérios de compensação dos fatores que medem os valores e a escassez dos recursos necessários para aplicar os citados métodos, que são complexos e cuja utilização requer muito tempo. Muitas vezes não é conveniente ao setor público se recorrer a essa análise complexa para se tomar uma decisão.

Dos exemplos dos casos de valoração ambiental, podemos entender que há dificuldades intrínsecas à estimativa de valor de bens não diretamente monetarizáveis, como é o caso de propriedades que tenham interesse ambiental. De qualquer modo, julgamos ser de fundamental importância que lei nacional regule os principais critérios a serem observados pelo avaliador, pois os laudos confeccionados pelos peritos são fundados em normas muito distantes de princípios fundamentais de economia.

Contudo, também é importante observar que, nesses casos, é inapropriado o uso de técnicas avaliatórias baseadas no custo de reprodução de um bem natural, ou num aproveitamento hipotético ilegal, técnicas essas que elevam os resultados de forma exagerada, conforme mostraram os exemplos de superavaliação, como os que ocorreram no caso do Parque Estadual da Serra do Mar.

\subsection{Instrumentos legais relacionados à desapropriação}

Tendo em vista a edição do Estatuto da Cidade e da Lei que cuida das parcerias público privadas na Administração Pública, surgem novas possibilidades ao instrumento de desapropriação ou combinações que podem, de certo modo, colocá-la em patamar de maior eficácia em tema de gestão da terra urbana. 
Há uma tendência dos Estados Nacionais em assumir o papel de regulador dos serviços e funções públicas ao invés de assumir sua execução, que, por contrato, são delegadas aos particulares ${ }^{69}$. Nesse sentido, os instrumentos abaixo analisados, são regulados para que a iniciativa privada tenha uma maior participação nas intervenções urbanas de modo a garantir o interesse público e requer uma nova postura dos atos das administrações públicas brasileiras, bem assim das decisões de desapropriar áreas.

Asseveramos que a função reguladora não significa renúncia ao poder fiscalizatório, pelo contrário, diante dessa inevitável mudança estatal, exige-se sua maior eficiência, sob pena de propiciar efeitos de difíceis dimensões sobre os territórios da cidade.

\subsection{Parcerias público privadas}

Sob o tema parcerias na Administração Pública, deve-se entender todo ato envolvendo o Poder Público e o setor privado para atingir um resultado de interesse público.

Na Administração Pública brasileira, um dos grandes óbices à realização de parcerias com o setor privado, é o do princípio da legalidade que rege toda atuação estatal.

Com a crise do modelo do Estado Social ou do Bem Estar, o Brasil, a partir da década de 90 do século passado, passou a introduzir em seu ordenamento jurídico, modelos legais em que a parceria com o setor privado era o principal objetivo. Dessa forma, conjuntamente com as privatizações de estatais e a terceirização de serviços, surgiu a Lei de Concessões de Serviços Públicos, Lei nº 8.987 de 13 de fevereiro de 1995, em que se disciplinou a transferência da execução de serviços públicos para o setor privado, cuja titularidade foi mantida do Poder Público.

\footnotetext{
${ }^{69}$ Nesse sentido ver estudo a respeito do agente urbanizador da cidade de Valência, em tese de doutorado de Alfonsin (2007, p.85)
} 
Ainda, a legislação brasileira disciplina outros modelos de parcerias, como as Leis no s. 9.637, de 15 de maio de 1998 e 9.790,de 23 de março de 1999, leis que cuidam de parcerias com o terceiro setor para a prestação de serviços sociais. Destaque-se que a Lei ${ }^{\circ}$. 10.257, de 10 de julho de 2001, que instituiu o Estatuto da Cidade, cuida das parcerias destinadas a implantar empreendimentos urbanísticos, como é o caso do instituto da operação urbana e do consórcio imobiliário.

Nesse contexto se desenvolveu a idéia de criação de uma legislação sobre parcerias público-privada, as PPPs, para que o Brasil pudesse adotar práticas bem sucedidas, como por exemplo, na Europa e no Chile.

O que se necessitava, na verdade, era de legislação específica para parcerias cujos objetivos não eram tratados pelas legislações até então editadas, isto é, era necessária uma legislação que completasse a já existente, para viabilizar contratos importantes para a administração, mas que por ausência legislativa não poderiam se realizar.

Assim, em dezembro de 2004, surgiu a Lei das PPPs, a Lei nº. 11.079, de 30 de dezembro, que na verdade não é a única legislação que rege as parcerias, mas sim uma lei que disciplina duas espécies de concessões do Poder Público: a concessão patrocinada e a concessão administrativa.

Em sentido estrito, PPPs são vínculos de natureza contratual, estabelecidos após a realização de licitação na modalidade concorrência, que adotem o modelo de concessão patrocinada ou de concessão administrativa. Em outras palavras, as PPPs são uma nova modalidade de concessão para obras necessárias ao desenvolvimento do país, mas cujo retorno econômico pode não ser suficiente para estimular a iniciativa privada. 
A nova lei garante ao empreendedor privado um retorno mínimo para o seu investimento. Parte do retorno será custeado pela a cobrança de tarifas pelos usuários do serviço, e outra parte, pela União, Estados ou Municípios. Em alguns casos, a remuneração do investidor poderá vir, em grande parte, das contraprestações públicas, que só poderá ser paga pelo governo depois do empreendimento começar a funcionar e se as metas de qualidade forem cumpridas.

Também não se podem confundir as concessões das PPPs com as previstas na Lei nº 8.987 de 13 de fevereiro de 1995, pois nestas a remuneração do concessionário se dá basicamente pela cobrança de tarifas dos usuários e, eventualmente por contraprestação do Poder Público, que não pode ser em pecúnia.

Estabelece o artigo $4^{\circ}$, III, da Lei das PPPs, que não podem ser atribuídas ao setor privado as "funções de regulação, jurisdicional, do exercício de poder de polícia e outras atividades exclusivas do Estado". Embora a Lei das PPPs tenha tratado dos serviços públicos que não podem ser delegados ao setor privado, a questão permanece em aberto, pois a disciplina legal ainda é muito vaga.

Uma das abordagens possíveis é a de que polícia, justiça, forças armadas são serviços públicos essenciais que o Poder Estatal guarda para si e não delega a particulares. Já a geração, transmissão e distribuição de energia elétrica, os serviços de distribuição de água e coleta de esgoto, de construção e gestão de estradas, estes sim são serviços públicos compreendidos como possíveis de ser objeto de concessão a particulares.

O núcleo das concessões previstas na Lei das PPPs é o de gerar compromissos estatais firmes e de longo prazo. Como o concessionário fará investimentos de longo prazo, dois objetivos se colocam: tanto impedir que o administrador presente comprometa 
irresponsavelmente recursos públicos futuros, como o de oferecer garantias que convençam o particular a investir.

Os projetos de PPPs deverão estar previstos nos Planos Plurianuais, tanto no federal, como nos estaduais e nos municipais. Esses planos, que olham apenas quatro anos à frente, nos moldes em que são concebidos, talvez não sejam suficientes para legitimar a decisão de investir, bem como de assegurar a validade econômico-social e garantir a obrigação do governo até 2040.

O planejamento de longo prazo, no Brasil, precisa agora, com a nova cultura das PPPs, seguir um novo modelo, no sentido de mostrar quem detém o poder de planejar, qual é o processo formal que legitima esse planejamento, que restrições se criam a novos projetos que não sigam o rito legal. É legítimo, para a sociedade, buscar reduzir a liberdade do agente político nas decisões de investimentos públicos, vinculando os governos futuros.

O certo é que o país não tem mais capacidade de investir em infra-estrutura e os instrumentos desenhados pelas PPPs constituem-se em alternativas importante para a mobilização de recursos necessários à implantação da infra-estrutura do país.

Nos modelos previstos pela Lei das PPPs, não há proibição de que o investimento inicial, de no mínimo R\$ 20 milhões, seja em áreas necessárias à ampliação ou criação de equipamentos de infra-estrutura.

Além disso, a previsão da legal da parceria público privada pode ser importante instrumento para a realização de obras urbanísticas, através da concessão urbanística, cuja possibilidade de realização era discutida. 
Anteriormente à lei de PPP's autores como Dallari (1980, p.113) defendiam possibilidade do Poder Público realizar a desapropriação para fins urbanísticos, com revenda dos imóveis a terceiros:

\footnotetext{
"Quanto à chamada desapropriação por zona, concluímos por sua larga possibilidade de utilização para fins urbanísticos, destacando que a área desapropriada em quantidade excedente à de utilização imediata pode ser utilizada legalmente como reserva de terras para futuras ampliações, para revenda, com a conseqüente obtenção da mais-valia, e para um número indeterminado de aplicações tipicamente urbanísticas, das quais destacamos a implementação de programas de habitação popular, pois as áreas assim obtidas podem ser vendidas sem lucro, doadas ou permutadas".
}

A evolução do instituto da desapropriação para abarcar finalidades urbanísticas, tinha por objetivo possibilitar que não só o Poder Público fosse o destinatário final do bem expropriado, mas também o particular.

Assim, em 1999, a Lei n 9.785, de 29 de janeiro, introduzindo alínea “ $i$ ” ao art. $5^{\circ}$ do Decreto-Lei $n^{\circ}$. 3.365, de 21 de junho de 1941, que disciplina a desapropriação por utilidade pública, previu que os casos de desapropriação para execução de planos de urbanização,e para parcelamento do solo, poderiam ter os bens expropriados alienados.

Contudo, alguns autores já previam a possibilidade de outra hipótese de desapropriação em favor de particular, a chamada concessão urbanística. Na concessão urbanística, espécie de obra pública em que o investidor se remunera com a venda posterior dos bens, o beneficiário promove, ele mesmo, a desapropriação, em função da autorização do Poder Público prevista em contrato. Tal conclusão é extraída do art. $3^{\circ}$, do Decreto-Lei $n^{\circ}$. 3.365, de 21 de julho de 1941, que determina “os concessionários de serviços públicos e os estabelecimentos de caráter público, ou que exerçam funções delegadas do Poder Público, poderão promover desapropriações, mediante autorização expressa constante de lei ou contrato”. 
Destarte, muita controvérsia surgia a respeito da aplicação da Lei de Concessões de Serviços Públicos a essa espécie de concessão, Lei nº 8.987, de 13 de fevereiro de 1995, pois referida legislação tem como objeto transferência de serviços públicos de natureza econômica, para exploração por parte do setor privado. Porém, muitas vezes a obra urbanística não terá esse caráter de exploração econômica e, com o advento da Lei das PPPs, a concessão urbanística poderá ser mais bem acomodada, consoante definição da modalidade concessão administrativa.

Diante da breve digressão sobre as parcerias existentes no País e das considerações das novas modalidades introduzidas em nossa legislação pela Lei $\mathrm{n}^{\circ}$. 11.079, de 30 de dezembro de 2004, podemos avaliar, a despeito de todas as discussões que envolvem o tema, que um novo enfoque começa a ser esboçado, o que permitirá a realização de outros modelos de contratação com a Administração Pública.

\subsection{A concessão urbanística e a desapropriação em favor de particular}

O interesse público sempre foi compreendido como aquele que o Estado procura alcançar. Contudo, no decorrer dos anos esta concepção foi submetida a profundas alterações.

Inicialmente o interesse público era apenas analisado pela sua origem, ou seja, independentemente dos resultados os atos do Estado o visavam; hoje, tais interesses encontram-se qualificados de acordo com os resultados obtidos, e tal persecução pode ser proposta não apenas pelo Estado, mas também particulares em forma de sociedade organizada ou não.

A situação supra mencionada interfere também na atividade urbanística. Nesta atividade o Estado atua na disposição e orientação para o uso do território, contudo não há de 
esquecer-se da importante contribuição dos particulares. Essa idéia também repercute no emprego da desapropriação.

Tal reformulação do instituto é conceituada claramente por Faria ( 1977, p. 104):

\begin{abstract}
"Para o direito urbanístico a expropriação por utilidade pública não é tanto, ou não é sequer encarada como "restrição ao direito de propriedade privada pelo Poder Público" mas antes como um dos meios ou instrumentos de execução das directivas de ordenamento territorial previamente fixadas. Isto explica, por um lado, que a expropriação se não reporte apenas a bens pertencentes à esfera jurídica privada, mas possa incidir ainda sobre bens integrados na esfera jurídica de entidades públicas e explica, por outro lado, que nem sempre a entidade expropriante seja de direito público, admitindo-se hoje que a utilidade pública se reporte a iniciativas de direito privado".
\end{abstract}

Ao expandir a chamada "utilidade pública" para além dos conceitos de obras, serviços, e domínio público, cria-se uma nova problemática, que Pinheiro (2004, p.93) delimita como: “O que se chama, portanto, de desapropriação para fins urbanísticos em favor de particular é toda desapropriação utilizada como instrumento de intervenção urbanística, que tenha como beneficiário último do bem expropriado, uma pessoa privada”.

A alienação de bens desapropriados encontra-se prevista em nosso ordenamento, e encontra fundamento no Decreto-Lei ${ }^{\circ}$. 3.365, de 21 de julho de 1941, art. $4^{\circ}$, em que se autoriza a alienação de propriedades valorizadas devido a investimentos por parte do Estado e é mecanismo de recuperação das mais valias. Ainda que gere algumas hesitações, esse instituto encontra-se em perfeita consonância com a contribuição de melhoria, e pode ser utilizado cumulativa ou alternativamente.

Há de se ressaltar que cabe ao Estado propiciar melhorias para o regular desenvolvimento da população, contudo, as habitações, os centros comerciais e as indústrias, devem pertencer ao setor privados; o que acaba por gerar a utilidade de alienação de bens expropriados para aqueles que possam cumprir com a função estabelecida, uma vez que não é interessante ao Estado ser detentor de um vasto patrimônio imobiliário. 
O Estatuto da Cidade estabeleceu ao Município o prazo de cinco anos para efetivar a destinação social que incitou a expropriação, após a incorporação do imóvel ao seu patrimônio,. Tal efetivação pode-se dar pelo próprio Poder Público, ou pelo setor privado.

Outra forma conhecida de desapropriação para fins urbanísticos consiste na chamada desapropriação na concessão urbanística. Essa é definida por Pinheiro (2004, p.102) como sendo a desapropriação em que: "o particular beneficiário promove, ele mesmo, a desapropriação, eliminando a etapa na qual o bem integra o patrimônio publico, para só posteriormente ser transferido a um particular que lhe de o destino socialmente útil".

A concessão urbanística consiste em uma autorização por parte do Poder Público para particulares a fim de realizar obras publicas viabilizando a urbanização ou mesmo revitalização de áreas já urbanizadas

Silva (2006, p. 324) trabalha a possibilidade da concessão urbanística para particular nos seguintes termos:

\begin{abstract}
"A concessão urbanística consiste numa espécie de concessão de obras publicas não para a exploração de serviços subseqüente e ressarcimento mediante a cobrança de tarifas. Tratar-se-á, então, de uma concessão pura de obras publicas não concessão mista de obras publicas figura que desponta na Dogmática Jurídica ainda muito timidamente. O já citado Francisco Lliset Borrell da-nos o essencial de sua configuração, quando preleciona nos termos seguintes: "A concessão pura de obra publica tem por objeto a transferência de faculdades próprias da Administração a um particular para a execução de obras de uso e aproveitamento gerais e de construções destinadas a serviços que se achem a cargo do Estado, Província ou Municípios, de cujo custo o concessionário se integrara não através de tarifas de prestação de serviços ou de oferecimento de bens ao uso publico, mas através da exploração de mais-valias ou subprodutos da obra mesma". 'E o caso, por exemplo, de o Poder Publico municipal elaborar um plano de reurbanização ou de renovação urbana de alguma área; sendo esta de propriedade privada, será desapropriada para a execução do plano - execução esta que poderá ser feita diretamente pelos órgãos da Prefeitura ou por empresa publica desta, como a EMURB (Empresa Municipal de Urbanização de São Paulo) ou por via de concessão; por esta, o concessionário assume os encargos da execução do plano, com o direito de venda de parcelas ou de novas edificações da área urbanificada".
\end{abstract}

Cabe salientar que, a concessão urbanística não deve ser compreendida nem como uma espécie de prestação de serviços para realização de determinada obra, nem como mera 
concessão de serviços públicos, situação que permite seja a mesma viabilizada também pela Lei que criou as PPPs.

Há de se ressaltar que a concessão é oferecida ao particular apenas no que se refere à execução da obra, a titularidade ou regulação permanece com o Poder Público. Deve ser fiscalizada por ele, e, principalmente, ser estabelecida de acordo com seus padrões, plano diretor e leis municipais.

Assim, o poder de executar a desapropriação não é exclusivo de entes políticos e os bens desapropriados, conseqüentemente, nem sempre ingressam no domínio da entidade que declarou a utilidade pública do bem, porém, ainda que particulares possam se utilizar de bens expropriados para a execução de planos urbanísticos será necessário o ato declaratório, para posterior promoção da desapropriação.

Verifica-se então que a própria Constituição Federal não impõe que o bem expropriado deva obrigatoriamente compor o patrimônio público. O que o instituto da desapropriação visa é o interesse público, e devido ao fato de ter a Administração Pública como sua primordial função a persecução do interesse público, não quer dizer que apenas através dela seja possível alcançar tal objetivo. O que é inaceitável é como fundamento da desapropriação o interesse particular. Assim como na revenda de propriedades já expropriadas, cujo aspecto fundamental é que o interesse público permaneça como objetivo.

\subsection{Operações urbanas consorciadas}

Considera-se operação urbana consorciada o conjunto de intervenções e medidas coordenadas pelo Poder Público Municipal, com a participação dos proprietários, moradores, usuários permanentes e investidores privados, com o objetivo de alcançar em uma área 
transformações urbanísticas estruturais, melhorias sociais e a valorização ambiental, consoante $\S 1$ o do art. 32, do Estatuto da Cidade.

Prevê o Estatuto da Cidade que "Lei municipal específica, baseada no plano diretor poderá delimitar área para aplicação de operações urbanas consorciadas "(art. 32, caput).

Poderá ser previstas nas operações urbanas consorciadas a modificação de índices e características de parcelamento, uso e ocupação do solo e subsolo, bem como alterações das normas edilícias, considerado o impacto ambiental delas decorrente; e a regularização de construções, reformas ou ampliações executadas em desacordo com a legislação vigente, além de outras medidas.

Destaca-se deste instituto a possibilidade de o Poder Público municipal efetuar "parcerias" com a iniciativa privada com a finalidade de procederem, juntos, melhorias urbanísticas e sociais.

O Estatuto da Cidade prevê que lei específica deverá aprovar a operação urbana consorciada. Esta lei incluirá em seu texto "plano de operação urbana consorciada" que deverá conter requisitos mínimos a serem preenchidos a fim de que a mesma seja executada. São eles: I - definição da área a ser atingida; II - programa básico de ocupação da área; III programa de atendimento econômico e social para a população diretamente afetada pela operação; IV - finalidades da operação; V - estudo prévio de impacto de vizinhança; VI contrapartida a ser exigida dos proprietários, usuários permanentes e investidores privados em função da utilização dos benefícios previstos nos incisos I e II do $\S 2^{\circ}$ do art. 32 desta Lei; VII- forma de controle da operação, obrigatoriamente compartilhado com representação da sociedade civil. 
A operação contará com forma de controle, obrigatoriamente compartilhado com representação da sociedade civil. Assim, a consecução das operações deverá ser fiscalizada não só pela administração, mas também pela sociedade civil, a fim de inibir desvio de finalidade.

Registre-se, ainda, que o Estatuto da Cidade ao disciplinar os requisitos que devem conter o plano da operação urbana consorciada o fez de forma meramente enumerativa, abrindo-se oportunidade ao Poder Público Municipal exigir ainda outros requisitos como, por exemplo, estudo de impacto ambiental para acautelar a medida, quando houver interface ambiental.

O beneficiado com a regularização de seu imóvel prestará contrapartida em dinheiro que será utilizada exclusivamente na consecução da operação urbana consorciada (§ $1^{\mathrm{o}}$ do art. 33) e, seu controle obrigatoriamente compartilhado com representação da sociedade civil.

Prevê o Estatuto da Cidade que a partir da aprovação da lei específica de que trata o caput, do art. 33 são nulas as licenças e autorizações a cargo do Poder Público Municipal expedidas em desacordo com o plano de operação urbana consorciada.

Esta providência se justifica porquanto a partir da aprovação da operação, determinadas áreas da cidade serão submetidas a novas regras. Desse modo, impõe-se que licenças e autorizações estejam de acordo com a nova disciplina e não com o anteriormente disposto no plano diretor.

Disciplina, ainda, o Estatuto da Cidade que a lei específica que aprovar a operação urbana consorciada poderá prever a emissão pelo Município de quantidade determinada de certificados de potencial adicional de construção (CEPAC), que serão alienados em leilão ou 
utilizados diretamente no pagamento das obras necessárias à própria operação, conforme tratado no item abaixo.

\subsection{Os certificados de transferência de potencial construtivo}

A emissão dos certificados de potencial adicional de construção - CEPAC - é forma de financiamento de infra-estrutura e também de pagamento de obras públicas e de áreas desapropriadas, em determinado espaço delimitado da cidade, especificado em lei, o qual se denomina operação urbana.

Desse modo, podemos afirmar que os certificados e potencial adicional de construção não se constituem em mecanismo autônomo de aumento de coeficiente, ao contrário, são sempre vinculados a uma operação urbana especificada em lei municipal.

Referidos certificados não podem ser equiparados aos tributos, cuja cobrança é uma imposição estatal independente da vontade do contribuinte.

Com efeito, a emissão e venda dos CEPACS constituem forma de arrecadação voluntária de recursos, não havendo compulsoriedade prevista na lei para a compra de CEPACS pelos proprietários, moradores ou investidores.

Adquiridos os CEPACS, os mesmos ficam vinculados a um futuro projeto a ser edificado na área delimitada da operação urbana, podendo ser negociados livremente, até que se convertam em adicional de construir ou alteração de uso.

As exigências para a utilização dos CEPACS vêm descritas em lei federal, o Estatuto da Cidade e, no caso de São Paulo, foram disciplinadas na Lei Municipal no 13.260, de 28 de dezembro de 2001 que aprovou a Operação Urbana Consorciada Água Espraiada. 
Na verdade os certificados de potencial adicional de construção são os veículos que operacionalizam o instituto da outorga onerosa de potencial adicional de construção, quando tiver previsão para ser instituída em uma determinada operação urbana. Além disso, também são instrumentos veiculadores de autorização para modificação de usos e parâmetros urbanísticos.

Desse modo, a outorga onerosa de direito de construir, quando instituída em área delimitada como de operação urbana, será efetivada através da compra dos referidos certificados.

Quando utilizados pelos investidores constituem-se nas contrapartidas pela utilização de área adicional de construção e pela modificação do uso do solo, que superem os padrões estabelecidos pela legislação urbanística, respeitados os limites previstos na lei específica que criou a operação urbana.

No entanto, também podem ser utilizados pelo Município para pagamento das obras previstas no programa de intervenção da operação urbana e como forma de pagamento aos proprietários de imóveis atingidos por desapropriações, e, nessa situação, têm colocação privada.

De forma genérica o Estatuto da Cidade prevê a possibilidade de o Poder Público custear obras públicas necessárias à implantação da operação urbana com CEPACS, o que, em tese, engloba a idéia de que também as áreas desapropriadas para a realização dessas obras públicas possam ser indenizadas com os CEPACS.

Diante dessa hipótese, o atual plano diretor da Cidade de São Paulo, Lei $n^{\circ}$ 13.430, de 13 de setembro de 2002, em seu art. 230, inova ao prever expressamente que tanto as obras públicas, como as áreas que precisarem ser desapropriadas pelo Poder Público para 
atender à operação urbana poderão ser pagas com os CEPACS. E, essa possibilidade, foi detalhada pelo Decreto Municipal no 44.417, de 26 de fevereiro de 2004, que regulamentou a emissão dos CEPACS, estabelecendo que para o pagamento de desapropriações necessárias às intervenções da operação urbana consorciada, os CEPACS somente poderão ser utilizados diretamente após a publicação do decreto expropriatório, a avaliação administrativa ou judicial para a determinação do valor do bem e da celebração de documento comprobatório em que haja a concordância do expropriado em receber a indenização, ou parte dela, em CEPACS. O valor dos CEPACS para esses casos será aquele negociado no último leilão público.

De qualquer forma, trata-se de experiência pioneira, dentro de um quadro de escassez de recursos públicos para investimentos, sobretudo em desapropriações, cujo bom êxito só poderá ser avaliado, após a execução da operação urbana Água Espraiada, a qual se constituirá em verdadeiro divisor de águas no tocante às práticas de projetos de desenvolvimento urbano experimentados no país.

\subsection{Direito de preempção}

O direito de preempção é o direito de preferência que o Poder Público Municipal terá para a aquisição de imóvel urbano objeto de alienação oneroso entre particulares. Depende de lei municipal baseada no plano diretor, que delimitará as áreas em que incidirá o direito e fixará um prazo de vigência não superior a cinco anos, renovável a partir de um ano após o decurso do prazo inicial de vigência.

O art. 26 aponta as hipóteses em que poderá o Poder Público Municipal exercer o direito de preferência. A lei municipal prevista no $\S 1^{\circ}$ do art. 25 deverá enquadrar cada área em que incidirá o direito de preempção em uma ou mais das finalidades enumeradas no art. 
26, quais sejam, regularização fundiária; execução de programas e projetos habitacionais de interesse social; constituição de reserva fundiária; ordenamento e direcionamento da expansão urbana; implantação de equipamentos urbanos e comunitários; criação de espaços públicos e lazer e áreas verdes; criação de unidades de conservação ou proteção de áreas de interesse ambiental; proteção de áreas de interesse histórico, cultural ou paisagístico.

O art. 27 dá um prazo de trinta dias para que o Município, após a notificação que lhe for feita pelo proprietário da sua intenção de alienar o imóvel, para manifestar por escrito a sua intenção de comprá-lo. $\mathrm{O} \S 3^{\circ}$ do art. 27 diz que transcorrido esse prazo o proprietário estará autorizado a realizar a alienação para terceiros nas condições da proposta apresentada. $\mathrm{O} \S 5^{\circ}$ dispõe que a alienação processada em condições diversas da proposta apresentada é nula de pleno direito e o $\S 6^{\circ}$ diz que se ocorrer tal hipótese, o Município poderá adquirir o imóvel pelo valor da base de cálculo do IPTU ou pelo valor indicado na proposta apresentada, se este for inferior àquele.

Vê-se que referidas hipóteses permitem que a preempção pode se constituir importante instrumento para evitar-se o uso do instrumento da desapropriação, pressupondo um planejamento mais efetivo por parte do Município. Referido instrumento induz a aquisição de áreas pela via administrativa, embora não afaste a problemática que envolve o tema da avaliação.

\subsection{Outorga onerosa do direito de construir e de alteração de uso}

Urbanisticamente, a idéia de solo criado pressupõe a adoção de um coeficiente único de aproveitamento do solo em determinada municipalidade e, as construções acima desse coeficiente autorizam a cobrança por parte do Poder Público municipal. 
O instituto da outorga onerosa apresenta-se como instrumento útil, sendo forma de controle do adensamento urbano, da utilização desordenada dos lotes sem atenção aos equipamentos urbanos existentes, e, finalmente, pode constituir-se em meio razoável de retorno de áreas ao Poder Público, sem a necessidade de vultosas expropriações, inclusive para o estabelecimento de áreas verdes e a implantação de equipamentos comunitários.

Todo aproveitamento de terreno, no subsolo, no solo e no espaço-aéreo, implicando criação de solo (piso artificial, além do limite), desde que consentido pelas condições peculiares do solo municipal, consubstanciará para o beneficiário a obrigação de dar à comunidade uma contraprestação pelo excesso de construção, que geralmente determina uma sobrecarga sobre o equipamento urbano.

O art. 28 do Estatuto da Cidade diz que o plano diretor fixará áreas nas quais o direito de construir poderá ser exercido acima do coeficiente de aproveitamento básico adotado, mediante contrapartida e prestação pelo beneficiário. $\mathrm{O} \S 1^{\circ}$ define coeficiente de aproveitamento como a relação entre a área edificável e a área do terreno.

É o plano diretor que, se for o caso, deverá fixar coeficiente de aproveitamento básico único para toda a zona urbana ou diferenciado para as áreas específicas dentro da zona urbana (art. 28, $\left.\S 2^{\circ}\right)$.

\subsection{Transferência do direito de construir}

A transferência do direito de construir é instrumento criado pelo Estatuto da Cidade em seu art. $4^{\circ}$, inciso V, alínea "o", a fim de compensar o proprietário de imóvel urbano, público ou particular, considerado necessário pelo Poder Público para fins de:

a) implantação de equipamentos urbanos e comunitários; 
b) preservação, quando o imóvel for considerado de interesse histórico, ambiental, paisagístico, social ou cultural;

c) servir a programas de regularização fundiária, urbanização de áreas ocupadas por população de baixa renda e habitação de interesse social (art. 35).

Deverá ser utilizado nos casos em que, embora determinado imóvel seja considerado necessário para o interesse público, e não há interesse em sua desapropriação ou tombamento. Assim, ao invés de o Poder Público expropriar o imóvel, medida radical, faculta-se ao proprietário o exercício de seu direito de construir em outro local ou sua alienação a terceiro.

Desse modo, diferentemente da outorga onerosa do direito de construir, que como visto, é instrumento pelo do qual o Poder Público Municipal concede ao proprietário a faculdade de exercer seu direito de construir acima do coeficiente de aproveitamento básico do adotado, mediante contrapartida por ele prestada; a transferência do direito de construir possibilita ao proprietário exercer em outro local o direito de construir até o coeficiente máximo ou, ainda, alienar, mediante escritura pública para terceiro o potencial de construção, como forma de compensação à limitação administrativa sofrida.

Em outras palavras, se por força do plano diretor ou de lei que determine ao proprietário de imóvel urbano possuir direito de construir acima do coeficiente de aproveitamento básico do adotado, uma vez sendo este imóvel considerado necessário para os fins previstos nos incisos I a III do art. 35, nasce para o proprietário o direito de exercê-lo em outro local ou de aliená-lo, transferência gratuita ou onerosa, a outrem. A mesma faculdade poderá ser concedida ao proprietário que doar ao Poder Público seu imóvel, ou parte dele, para os mesmos fins. 
Mesmo que o direito de construir em relação a determinado imóvel deixe de existir em sua totalidade por razões que o Estatuto da Cidade declina, incisos I a III do art. 35, ele pode ser exercido em outro local ou alienado a terceiro.

Observe-se, que a transferência do direito de construir independe da existência de operação urbana consorciada em andamento, porquanto se restringe à imóvel específico considerado necessário para os fins previstos no Estatuto da Cidade.

Tendo em vista que incumbe às autoridades municipais a tarefa de definir regras locais de ordenação do solo, o Estatuto da Cidade deixou aos Municípios a tarefa de reger a questão do direito de construir ( $§ 2^{\circ}$ do art. 35), mediante lei específica que deverá seguir as diretrizes gerais fixadas pelo Estatuto da Cidade (art. $2^{\circ}$ ). Esta Lei municipal deve disciplinar com rigor da forma do exercício do instituto, estabelecendo as condições relativas à sua aplicação.

Trata-se, portanto, de instituto inovador que trará fortes mudanças no mercado imobiliário, pois destaca o direito de construir do direito de propriedade, tornando-o um direito autônomo, que pode ser negociado livremente e sua utilização já é experimentada nas desapropriações por interesse público. Os proprietários das áreas afetadas pela desapropriação recebem autorização para exercer em outro local o potencial construtivo dessas áreas, ou aliená-los, como foi o exemplo da construção da Perimetral III, em Porto Alegre (FURTADO, 2006).

\subsection{Arbitragem no âmbito das desapropriações}

Oliveira (2005, p. 508) propõe a possibilidade de utilização do juízo arbitral como meio de solução de litígios e controvérsias originados de relações jurídicas contratuais entre a Administração Pública e os particulares. 
De acordo com o autor, o entendimento favorável ao emprego da via arbitral para a solução das questões assinaladas não deve ser generalizado. Tal matéria suscita grande divergência, que pode ser comprovada em decisões do $\mathrm{TCU}^{70}$ e na jurisprudência de nossas Cortes Judiciárias.

A autorização da arbitragem em situações peculiares aparece na legislação brasileira, principalmente envolvendo setores regulados por leis específicas (OLIVEIRA, 2005) como nos serviços de telecomunicação - inciso XV do art. 93 da Lei Federal n . 9.472, de 16 de julho de 1997 e exploração e produção de petróleo e gás natural - inciso X do art. 43 da Lei Federal nº. 9.478 de 6 de agosto de 1997..

Ainda que haja argumentos favoráveis e desfavoráveis apresentados nas doutrinas e jurisprudências administrativas e judiciárias, entendemos importante desenvolver melhor a questão em tema de desapropriação, o que poderia tornar o instrumento mais eficaz.

Segundo (ENTERRÍA; FERNÁNDEZ, 1997, p. 663 ) "a Administração negocia e a negociação converteu-se em um instrumento imprescindivel para a tarefa de administrar”.

O caminho da negociação, para composição de desentendimentos entre as partes, que pressupõe o reconhecimento da autonomia da vontade, é uma das principais consequiências da intensificação e estreitamento das relações entre o Estado, empresas e organizações da sociedade civil.

Com isso, em um cenário em que vigora a necessidade da realização de parcerias, a verticalização entre a Administração Pública e os particulares, é fortemente atenuada e até mesmo afastada; uma vez que não há uma relação de total subordinação entre as partes

\footnotetext{
${ }^{70}$ Não há entendimento uniforme firmado no âmbito do TCU com relação ao tema, embora a tendência revelada seja desfavorável à arbitragem nos contratos firmados pela Administração. Nesse sentido, cf. uma das decisões mais recentes: $2^{\text {a }}$ C., Acórdão 584/2003, j. 10.4.2003, DOU 28.4.2003.
} 
envolvidas. Como já destacamos neste trabalho, alguns postulados clássicos de direito administrativo necessitam de revisão. Não se trata de abandono ao Estado de Direito, mas de regular modelos compatíveis com as atuais demandas estatais.

A disciplina normativa a que são submetidas às relações negociais, das quais a Administração é parte, tem sido influenciada por essa nova realidade; tendo como efeito a criação de mecanismos legislativos mais adequados ao desenvolvimento das relações paritárias, além dos intensos câmbios na legislação preexistente.

Como reflexo dos câmbios citados acima, temos os contratos de parceria públicoprivada, os quais são regidos pela Lei $\mathrm{n}^{\mathrm{o}} .11 .709$, de 30 de dezembro de 2004. Esse novo contrato tem gerado acentuada divergência na Administração Pública brasileira, uma vez que se está diante de uma nova figura a ser empregada no campo do setor público negocial, instituindo e formalizando a relação jurídica entre a Administração Pública e os particulares, embasando-se em normas diversas daquelas disposições inseridas nas Leis $\mathrm{n}^{\mathrm{o}} \mathrm{s} .8 .666$, de 21 de junho de 1993 e 8.987 , de 13 de fevereiro de 1995.

Nesse âmbito, um dos novos paradigmas do Estado, abordado por Cassese (2001, p. 168) seria o fortalecimento da negociação na Administração Pública, expressada por meio dos acordos, em que "passam ao primeiro plano a negociação em lugar do procedimento, a liberdade das formas em lugar da tipicidade, a permuta em lugar da ponderação".

U um bom exemplo de arbitragem é a experiência portuguesa. Naquele país há um tribunal arbitral criado para fixar a justa indenização nas expropriações por utilidade pública, quando não for possível efetuar acordo entre as partes sobre o quantum indenizatório, ou, a expropriação for de natureza urgente, conforme arts. 38 da Lei 168/99.Isso também pode ser 
observado na Lei de Expropriação espanhola, de 16 de dezembro de 1954, em que a arbitragem é realizada por um júri de cinco integrantes, conforme arts. 31 e 32.

No Brasil é o Judiciário que concentra a função de arbitrar o valor das indenizações, situação merece ser revista, a fim de conferir maior celeridade ao procedimento da desapropriação não fosse tão demorado. Ao Judiciário caberia analisar ações de improbidade na condução do procedimento arbitral, situação que também merece tratamento legislativo. 


\section{Capítulo 8}

\section{CONCLUSÕES}

O presente trabalho teve por objetivo estruturar elementos de reflexão sobre o instituto da desapropriação como instrumento de política urbana e ambiental, que possam contribuir para sua aplicação, que está a exigir, inclusive, nova regulamentação, em virtude do modelo legal seguido pelo Brasil através do Decreto-Lei nº 3.365, de 21 de junho de 1941 e Lei $\mathrm{n}^{\mathrm{o}} .4 .132$, de 10 de setembro de 1962 que tratam, respectivamente, de desapropriação por utilidade pública e por interesse social, e que se tornaram anacrônicos.

Embora o Estatuto da Cidade, Lei $\mathrm{n}^{\circ}$. 10.257, de 10 de julho de 2001, disponha que a desapropriação é instrumento jurídico da política urbana e tenha regulamentado a desapropriação-sanção prevista no artigo $8^{\circ}$, deixou de regulamentar aspectos importantes para que o instrumento possa ser utilizado para fins urbanísticos e ambientais.

O principal aspecto que merece um melhor tratamento, tanto legal como conceitual, é o tema da indenização, conforme pesquisas realizadas para esse trabalho. Os processos pesquisados destacaram problemas atuais do procedimento da desapropriação judicial e de sua aplicação por parte das administrações públicas e do Poder Judiciário paulista.

Pudemos comprovar que os critérios utilizados pelos peritos avaliadores para arbitrar o valor do imóvel nem sempre são uniformes e as divergências apresentadas nos laudos no que se refere aos valores de indenização são consideráveis, principalmente nos 
casos de áreas maiores, fato que, entre outros aspectos negativos, contribui para que o processo judicial seja demorado.

Por outro lado, o tema da indenização nas desapropriações tem sido objeto de tratamento bem cuidadoso no direito comparado, no qual são estudados critérios especiais para a fixação de justo preço, tema extremamente controvertido entre os estudiosos e a jurisprudência brasileira.

Outro ponto de destaque relativamente ao tema da indenização é o da aplicação dos juros compensatórios, criado pela jurisprudência brasileira a título de remuneração da renda que o proprietário deixou de receber em função da imissão de posse por parte do Poder Público. Referidos juros, acrescidos ao valor arbitrado no laudo, com este mantém grande relação, especificamente quanto ao método de avaliação adotado. Qualquer laudo que trabalhe com hipóteses sobre os ganhos que a propriedade poderia produzir, já incorpora a idéia dos juros compensatórios. Deste modo, ao se considerar, no laudo, os prejuízos do proprietário e a renda que ela deixará de auferir, ilegítima será a incidência de juros compensatórios sobre este montante. Continuar essa prática é permitir indenizar duplamente o proprietário.

Em virtude de sua complexidade, não deve o juiz adotar o laudo sem entender os princípios que o fundamentaram.

A esse respeito, a escolha do perito também é um problema para a aplicação do instrumento de desapropriação. O Poder Judiciário não possui em seus quadros profissionais especializados e, com permissão da lei, pode-se nomear perito de confiança. Verificamos que são raros os casos de juízes que estabelecem uma comunicação com esses peritos a fim de compreenderem os fundamentos dos laudos, situação que também contribuiu para que indenizações fraudulentas fossem perpetradas no bojo de processos judiciais. 
Nesse sentido, solução mais segura é que os juízes indiquem instituições ou profissionais reconhecidamente com autoridade para atuarem em avaliações, notadamente para os casos de maior complexidade. Outra hipótese seria a criação de tribunais especializados em desapropriações, ou, a realização de um credenciamento mais criterioso para a escolha dos profissionais que atuarão nas avaliações.

Nos casos estudados que tramitam na Fazenda Pública da Comarca de São Paulo, criou-se um grupo composto por técnicos que atuam no Município para uniformizarem regras de avaliação em processos de desapropriação CAJUFA - Centro de Apoio aos Juízes da Fazenda. Esses juízes também imprimiram uma nova marcha ao processo, redobrando esforços para obtenção de uma composição das partes em seu início, com base nos laudos realizados segundo as normas da CAJUFA.

Essa prática da Justiça da Fazenda Pública da Comarca de São Paulo, embora não solucione as divergências nos laudos, porque essas têm origem na ausência de critérios e fundamentos econômicos dessas avaliações, tem pontos positivos, principalmente nos casos de pequenas propriedades, em que a solução processual é abreviada. Além disso, há um esforço por parte dos juízes para que um depósito inicial seja realizado, o que redunda em indenizações mais econômicas para o Poder Público, em virtude de não haver a necessidade de incidir as taxas de juros e correção monetária sobre o montante total, só sobre a diferença apurada em laudo definitivo.

Embora o presente trabalho tenha priorizado o estudo dos problemas relacionados às indenizações em desapropriação, outras questões obstam a aplicação do instrumento de forma mais eficiente e, igualmente, necessitam de uma revisão não só legal, mas também conceitual, como é o caso de postulados administrativos contraditórios, que em nome de uma idéia ultrapassada de supremacia do interesse público sobre o particular, faz com que nossas 
administrações públicas tenham dificuldade em negociar com proprietários, bem como de criar novos modelos institucionais, a exemplo da arbitragem, para questões a serem solucionadas junto à Administração Pública. Essas contradições que ainda vigoram no direito administrativo brasileiro tornam a desapropriação excessivamente "judicializada", fato que contribui para abarrotar o judiciário com causas que poderiam ter solução mais justa e rápida em âmbito administrativo.

Enfim, com base nos processos pesquisados e em estudos do valor, e de sua estimativa, que indicam novos e promissores caminhos para a abordagem da questão da avaliação de bens, que deve utilizar bases distintas ao valor de mercado, conforme entendimentos que prosperam no campo aplicado da Economia Ambiental, concluímos que o Brasil necessita de lei que uniformize os critérios para avaliações em desapropriações, sobretudo nas de cunho urbanístico e ambiental, a fim de relacionar a avaliação diretamente aos princípios da função social da propriedade e da justa indenização, sem prejuízo de tomada de nova posição por parte dos poderes públicos para adotarem outros instrumentos urbanísticos para a captura de mais valias das áreas valorizadas por melhoramentos públicos, de forma combinada com o instrumento desapropriação.

Além disso, será necessária uma mudança dos paradigmas tradicionais presentes na Administração Pública brasileira, ou seja, com fundamento na lei, estruturar novos modelos institucionais que atribuam uma maior concretude e eficiência ao planejamento urbanístico e coordene seus instrumentos, como é o caso da desapropriação. 


\section{Referências}

\section{Bibliografia Básica}

AUBY, Jean-Marie; DUCOS-ADER, Robert. Droit Administratif: l'expropriation por cause d'utilité publique, l'aménagement du territoire, l'urbanisme et la construction. Paris: Précis Dalloz, 1980.

BUCCI, Maria Paula Dallari. Direito Administrativo e Políticas Públicas .São Paulo: Editora Saraiva. 2002

CAIRES, Hélio. "Avaliação de Glebas" in Engenharia de Avaliações. São Paulo: IBAPE. 1974.

CARCELLER FERNÁNDEZ, Antonio. Introducción al Derecho Urbanístico. $3^{\circ}$ ed.. ed. Madrid:Tecnos, 1997.

DALLARI, Adilson Abreu. Desapropriações para fins urbanísticos. Rio de Janeiro: Forense, 1981.

FERNANDES, Edésio. Direito Urbanístico. Belo Horizonte: Del Rey, 1998.

HADDAD, Emílio. "Comentários sobre os procedimentos utilizados no estabelecimento do valor de indenização de bens imóveis desapropriados pelo poder público, 2000 http://territorioysuelo.org

Reporto $n$ urban land market reserach in São Paulo, Brazil. In: CULLEN,M., WOOLERY,S. 9eds). World Congress on Land Policy. Lexington, Mass.:Lexington Books, 1980, cap. 13

"Bosquejos sobre el avalúo inmobiliario em cuanto arte del encuentro", Taller sobre avalúes y procesos de Gestión del Suelo, Bogotá: 2004 http://territorioysuelo.org

; Santos, Cacilda Lopes dos; Franco Junior, Reynaldo Silveira. Novas Perspectivas sobre o instituto da desapropriação: a proteção ambiental e sua valoração. Editora Fórum: Belo Horizonte, 2007.

INSTITUTO FLORESTAL. Desapropriação em parques e Estações Ecológicas. Relatório Elaborado por Grupo de Trabalho constituído pela Portaria D.G- I.F. de 25/04/95

IVSC. 2005 Edition of the International Valuation Standards. Londres: International Valuation Standards Committee, 2005 ,http://ivsc.org

LAB-HAB- FAU-USP - Relatório final do projeto de pesquisa - "Preço de desapropriação de terras: limites às políticas públicas nas áreas de habitação, meio ambiente e vias públicas em São Paulo", 2002. 
MAIA , Alexandre G. , ROMEIRO, Ademar R. E REYDON, Bastiann P. - Valoração de recursos ambientais - metodologias e recomendações - Instituto de Economia - UNICAMP - Campinas, 2004.

MINISTERIO DO MEIO AMBIENTE. Manual de Valoração Ambiental - http //www. mma.gov.br - Brasília - D.F., 2005.

MOTTA, Ronaldo Seroa, Manual de Valoração Econômica de Recursos Ambientais. IPEA / MMA / PNUD / CNPQ, Brasília, 1998.

In: Moran, D. e Moraes, A.S. Complex goods and contingent values:

valuing uncertainty environmental change in the Pantanal, Proceedings of the SCOPE Workshop on Integrated Adaptive Ecological Modelling, Pantanal, 5-7 de novembro, 1995.

The Role of Economic Criteria in Biodiversity Conservation. Brasília, Seminário GTZ/IBAMA, 1997

RABELLO, Sonia. Justa indemnización en las expropiaciones urbanas: justicia social y enriquecimiento sin causa. Trabalho preparado para apresentação no Workshop do IRGLUS 2002 - http://territorioysuelo.org

SMOLKA, Martim. Precio de la tierra y valorización inmobiliaria urbana: Esbozo para uma conceptualizacion del problema. RIAP XV, n. 60, p. 70-89, 1981.

\section{Bibliografia Complementar}

ALFONSIN, Betânia de Moraes. A política urbana em disputa: desafios para a efetividade de novos instrumentos em uma perspectiva analítica de Direito Urbanístico Comparado (Brasil, Colômbia e Espanha) - Tese de doutorado apresentada ao Instituto de Pesquisa e Planejamento Urbano e Regional da Universidade Federal do Rio de Janeiro - UFRJ - Rio de Janeiro - 2007.

ALMEIDA, Fernando dias Menezes de (coord.). Estatuto da Cidade: Lei 10.257, de 10.07.2001: Comentários. São Paulo: Revista dos Tribunais - RT, 2002.

ANDRADE, Lisa M. S. e ROMERO, Marta A. B. - A Importância das Áreas Ambientalmente Protegidas nas Cidades - XI Encontro Nacional da ANPUR: Salvador Bahia , 2005.

ASSOCIAÇÃO BRASILEIRA DE NORMAS TÉCNICAS. NBR 5676- NB 502 - Avaliação de Imóveis Urbanos. SãoPaulo: ABNT, 1995.

ASSOCIAÇÃO BRASILEIRA DE NORMAS TÉCNICAS NBR 8799 - NB 613 - Avaliação de Imóveis Rurais, São Paulo: ABNT, 1985.

ASSOCIATION OF ENVIRONMENTAL AND RESOURCE ECONOMICS. Journal of Environmental Economics and Managemente - http://www.aere.org/journal/index.html

AZEVEDO, Paulo B.M e HUMPHREYS , Rubens D. - Valoração dos Recursos Florestais em Ações de Indenização Ambiental - I. P. T. Instituto de Pesquisas Tecnológicas: São Paulo, 2004. 
AZUELA, Antonio. Visionarios y pragmáticos. Uma aproximación sociológica al derecho ambiental. México: Fontamara, 2006.

BARBI, Celso Agrícola. Comentários ao Código de Processo Civil (Lei 5.869, de 11.01.1973). v. I, ts. I e II. Rio de Janeiro: Forense, 1975.

BARROSO, Luís Roberto. Interpretação e aplicação da Constituição.São Paulo: Saraiva, 1996.

BRUNO FILHO, Fernando Guilherme; DENALDI, Rosana. Parcelamento, edificação e utilização compulsórios e a concretização da função social da propriedade: notas acerca de uma experiência. Revista Oculum Ensaios. Volume 06. Jul/dez de 2006, p. 35 a 47 PUCCAMPINAS

BUENO , C. - Valoração Econômica em áreas protegidas - serviços ambientais ainda não consideradas na gestão - $2^{\circ}$ Simpósio de Áreas Protegidas e Conservação no Âmbito do Cone Sul - Instituto de Geografia da UFRJ - Rio de Janeiro - R. J.

BUNGE, Mario. Teoria e Realidade. São Paulo: Perspectiva, 1974.

CAMPOS, Francisco. Direito Constitucional. v. I. Rio de Janeiro: Freitas Bastos, 1956.

CANOTILHO, José Joaquim Gomes. Direito constitucional. 5. ed. 2. reimp. Coimbra: Almedina, 1992.

CASSESE, Sabino. "La arena pública: nuevos paradigmas para el Estado". In: La crisis del Estado. Buenos Aires: Abeledo Perrot, 2003. p. 101-160.

CATALANO, Francis. "Le rôle du juge de l'expropriation", Études Fonciers" Paris: ADEF, disponível na página http:www.foncier.org/articles/76/74Catalano.html

CONCEIÇÃO, Sergio A.N. e SCHWENCK Junior, Paulo de M. - Exploração Econômica das Florestas Nativas - Procuradoria Geral do Estado de São Paulo - São Paulo, 2004.

COSTA, Antonio Pereira da. Uma tentativa de avaliação da aplicação do Código das Expropriações. Disponível em http://www.anmp.pt/anmp//div2003/semEXPRO/docdoc//2 pdf - acesso em 26/12/2007

COSTA, Regina Helena. O Estatuto da Cidade e os novos instrumentos da política urbana. Revista de Direito Imobiliário, São Paulo, v. 24, n. 51, p. 81-98, jul./dez . 2001.

COSTA NETO, Joaquim de Britto. A questão fundiária dos Parques e Estações Ecológicas do Estado de São Paulo. Origens e Efeitos da indisciplina da documentação e do registro imobiliário. Tese de Doutorado apresentada à FAU/USP. 2006.

COUSO, Javier A. La Produccuón del Derecho Económico Internacional y la Necesidad de una Demorcracia Cosmopolita." Trabalho pressentado al SELA, Punta del Este, Junio del 2002. Disponible em htpp:// islandia.law.yale.edu/sela/cousos.pdf 
DALLARI, Adilson Abreu; FERRAZ, Sérgio (coords.). Estatuto da Cidade. São Paulo: Malheiros, 2002.

DALLARI, Adilson Abreu; FIGUEIREDO, Lúcia Valle (coords.). Temas de Direito Urbanístico. São Paulo: Revista dos Tribunais, 1987.

DECLARAÇÃO do Rio sobre Ambiente e desenvolvimento de 06/1992. Disponível em http://www.diramb.gov.pt.htm

DERANI, Cristiane. Direito Ambiental econômico. São Paulo: Max Limonad, 1997.

DI PIETRO, Maria Sylvia Zanella. Direito Administrativo. 16. ed., São Paulo: Atlas, 2003.

DUBEUX, Carolina Burle Schmidt. Programa de Saneamento Básico da Bacia da Baía de Guanabara, Relatório de Referência para Solicitação de Empréstimo ao Banco Interamericano de Desenvolvimento, Rio de Janeiro, Governo do Estado, 1993 e Programa de Saneamento Básico da Bacia da Baía de Guanabara - BR 0072, Relatório de Projeto 1950 Banco Interamericano de Desenvolvimento, 1993.

DUGUIT, Leon. Las Transformaciones generales del Derecho privado desde el Código de Napoleón. Trad. Carlos G. Posada. 2. ed., Madrid: Beltran, 1920.

ENTERRIA, Eduardo Garcia de; FERNANDEZ, Tomás- Rámon. Curso de Direito AdministrativoII.e. ed. Madrid: Civitas, 1997.

FAGUNDES, Miguel Seabra. Da Desapropriação no Direito Brasileiro. $2^{\text {a }}$ edição. Rio de Janeiro: Freitas Bastos, 1949.

FARIA, Manuel Veiga de. Elementos de Direito Urbanístico.Coimbra: Editora Coimbra, 1977.

FAUSOLD, Charles J. Fausold and Robert J. Lilieholm, The Economic Value of Open Space: A Review and Synthesis, Working 1996 Published in Environmental Management, Vol. 23, No. 3: 307-320. Spring, 1999.

FILARDO JR., Ângelo S. - Externalidades e gestão dos valores do ambiente : considerações teóricas e uma aplicação ao caso do Programa Guarapiranga ( 1991 - 2000 ) - Tese de mestrado, Faculdade de Arquitetura e Urbanismo, São Paulo, 2005.

FRANÇA, Rubens Limongi. Manual Prático das Desapropriações (Aspectos Públicos, Privados e Processuais).São Paulo: Saraiva, 1976.

FIKER, José. Linguagem do Laudo Pericial. São Paulo: Editora Leud, 2005.

FIX, Mariana. Parceiros da Exclusão. São Paulo: Editora Boimtempo, 2001.

FUNDAÇÃO GETÚLIO VARGAS. "Uma análise jurídico-econômica dos precatórios judiciais do Grande ABC”. São Paulo. Novembro/2001. 
FURTADO, Fernanda. Recuperação de mais-valias fundiárias urbanas na América Latina: debilidade na implantação, ambigüidades na interpretação. Tese de doutorado, Faculdade de Arquitetura e Urbanismo, Universidade de São Paulo, São Paulo, 1999.

Instrumentos para a gestão social da valorização da terra: fundamentação, caracterização e desafios. In Programa Nacional de Capacitação das Cidades. Seminários Nacionais realizados no Rio de Janeiro, de 7 a 10 de fevereiro de 2006, Jaboatão dos Guararapes, de 9 a 12 de maio de 2006 e Brasília, de 6 a 9 de junhode 2006.

FURTADO, F.; REZENDE, V. L. F. M.; OLIVEIRA, M. T. C. ; YORGENSEN, P. ; BACELLAR, I. . Outorga Onerosa do Direito de Construir: panorama e avaliação de experiências municipais. In: XII Encontro Nacional da ANPUR, 2007, Belém. Integração sulamericana, fronteiras e desenvolvimento urbano e regional. Belém : Anpur - UFPA, 2007. v. 1

GAMA, Guilherme Calmon Nogueira da. Desapropriação Urbanística: Um instrumento jurídico de desenvolvimento urbano. Revista de Direito Administrativo. Rio de Janeiro, $\mathrm{n}$. 219, p. 153-177, jan./mar. 2000.

GASPARINI, Diógenes. Direito Administrativo, 7. ed., São Paulo: Saraiva, 2002.

GERMAN, Jerome C. German, Dennis Robinson and Joan Youngman, Traditional Methods and New Approaches to Land Valuation, Land Lines, July 2000.

GIL FILHO, Sylvio Fausto. Notas sobre a teoria do uso do solo urbano a partir de categorias analíticas marxianas. In: Revista Paranaense de Geografia, Curitiba, n. ${ }^{\circ}$ 02, p. 15-23, 1997.

GRAU, Eros Roberto. A Ordem Econômica na Constituição de 1988. $3^{\text {a }}$ ed. São Paulo: Malheiros, 1997.

GROSTEIN, Marta Dora. A cidade clandestina: os ritos e os mitos. Tese de Doutorado, Faculdade de Arquitetura e Urbanismo, Universidade de São Paulo, São Paulo, 1987..

HUGON, Paul. História das Doutrinas Econômicas. 13ª ed., São Paulo: Atlas, 1976.

INSTITUTO BRASILEIRO DE AVALIAÇÕES E PERÍCIAS DE ENGENHARIA - IBAPE - Engenharia de Avaliações. São Paulo: PINI, 1974.

IVSC. 2005 Edition of the International Valuation Standards, Londres: International Valuation Standards Committee, 2005 - Http://ivsc.org

JARAMILLO, Samuel. La experiencia colombiana en la recuperación estatal de los incrementos del precio del suelo. La Contribuición de Valorización y la Participación en Plusvalías. in Recuperación de Plusvalias en América Latina. Eurelibros/Lincoln Institute of Land Policy/ Pontifícia Universidad Católica de Chile, 2001.

LAUBÉ, Vitor Rolf. Desapropriação Urbanística. Revista de Informação Legislativa, Brasília, v. 29, n. 114, p. 205/229, abr./jun. 1992.

LOBO, Paulo Luiz Netto. Direito do estado federado ante a globalização econômica. Jus Navegandi. 2000. http://jus2.uol.com.br/doutrina/texto.asp?id=2243, acesso em 14/01/2008. 
YOUNGMAN, Joan, Introduction to Legal Issues in Property Valuation and Taxation, Published in Assessment Journal, March/April 1994, pp. 60-77

MADEIRA, José Maria Pinheiro. A questão jurídico-social da propriedade e de sua perda pela desapropriação. Rio de Janeiro: Lumens Júris, 1998, p. 251-252.

MACHADO, Paulo Afonso Leme. Direito Ambiental Brasileiro. São Paulo: Malheiros, 2001.

MAIA, Alexandre G., ROMEIRO, Ademar R. E REYDON, Bastian P. - Valoração de recursos ambientais - metodologias e recomendações - Instituto de Economia - UNICAMP - Campinas, 2004.

MARTINS JR., Wallace Paiva. Estatuto da Cidade e improbidade administrativa. Revista de Direito Imobiliário. São Paulo, v.25, n. 52, p.36-49.

MARX, Murillo. Cidade no Brasil terra de quem? São Paulo: Nobel/Edusp, 1991.

MEIRELLES, Hely Lopes. Direito Municipal Brasileiro. 12. ed., São Paulo: Malheiros, 2001. . Direito Administrativo Brasileiro. 27. ed., São Paulo: Malheiros, 2002.

MELlO, Celso Antônio Bandeira de. Curso de Direito Administrativo. 15. ed., São Paulo: Malheiros, 2003. Desapropriação - interesse social - plano de

urbanização. Revista de Direito Administrativo, n . 130, out./dez. 1997, p.353-354.

MINISTERIO DO MEIO AMBIENTE. Manual de Valoração Ambiental - http//www. mma.gov.br - Brasília - D.F., 2005

MORAES, Antonio C. Robert; COSTA, Wanderley Messias da. A valorização do espaço. $3^{\mathrm{a}}$ ed. São Paulo: Hucitec, 1993.

MOUNTFIELD, Helen. Regulatory Expropriation in Europe: The Approach of the European Court of Human Rights.11 N.Y.U. ENVTL. L.J. 136, 139 n.14 , 2002.

NOBRE JR., Edílson Pereira. Desapropriação para fins de reforma urbana. Revista de Informação Legislativa. Brasília, v. 39, n. 156, p. 81-91, out./dez. 2002.

OCHOA, Oscar Borrero. Avaluos para plusvalia. www.territorioysuelo.org/.../Presentaciones_foros/2005/Seminario_recuperacion_de_plusvali as/01_O_Borrero.pdf. acesso: em 13/01/2008.

PANIZZA FILHO, Danilo e outros ( juízes de direito na Capital do Estado de São Paulo ). Ação de Desapropriação. Teoria e Prática. São Paulo: Saraiva, 1999.

PINHEIRO, Renata, Peixoto. A Desapropriação como Instrumento de Intervenção Urbanística. Forum de Direito Urbano e Ambiental: Belo Horizonte, a. 1, n. 7, p. 619-625, jan./fev. 2003. 
PINHEIRO, Renata, Peixoto. Desapropriação para fins urbanísticos em favor de particular. Belo Horizonte: Editora Fórum, 2004.

PINTO, Victor Carvalho. Direito Urbanístico - Plano Diretor e Direito de Propriedade. São Paulo: Editora revista dos Tribunias, 2005.

Da Desapropriação com Pagamento em títulos. Estatuto da Cidade Comentado. Liana Portilho Mattos ( Organizadora). Belo Horizonte: Mandamentos, 2002.

PROCURADORIA GERAL DO ESTADO DE SÃO PAULO - Centro de Estudos biblioteca virtual Trabalho sobre as ações indenizatórias - htpp//www.pge.sp.gov.br -São Paulo, 2005.

REVISTA DE DIREITO ADMINISTRATIVO - RDA: 40,75, 98, 102103 ,109,119, 121

REVISTA DE JURISPRUDÊNCIA DO TRIBUNAL DE JUSTIÇA DO ESTADO DE SÃO PAULO - RJTJESP LEX: 91/133, 123/265, 583/289, 673/82

REVISTA DOS TRIBUNAIS- RT: 197,249, 317,341, 489, 583, 611

SALAMANCA, Luis M. Enriquez de. Naturaleza y alcance de la expropriación por razón de urbanismo. Madrid: Instituto de Estudios de Administración Local, 1973.

SALLES, José Carlos de Moraes. A Desapropriação à luz da doutrina e da jurisprudência. 5. ed., São Paulo: RT, 2006.

SANTOS, Cacilda Lopes dos. As influências da Legislação de Parcelamento do Solo na produção dos Espaços Urbanos. Dissertação de Mestrado, Pontifícia Universidade Católica de São Paulo, São Paulo, 2001.

SAULE, Nelson Junior. Novas perspectivas do Direito Urbanístico brasileiro. Ordenamento constitucional da política urbana. Aplicação e eficácia do Plano Diretor. Porto Alegre: Sergio Antonio Fabris (ed.) 1997.

A Proteção Jurídica da Moradia nos Assentamentos Irregulares. Porto Alegre: Sergio Antonio Fabris (ed.), 2004.

SCHECHINGER, Carlos Morales. Proceso de formación de los precios del suelo urbano. Relación con las decisiones urbanísticas. Documento preparado para el curso desarrollo profesional sobre recuperación de plusvalías en América Latina. 2004.

SCHWENCK, Paulo de Mello e Pedro Ubiratan Escorel de Azevedo (organizadores), Regularização imobiliária de áreas protegidas, São Paulo, Secretaria de Estado de Meio Ambiente: Procuradoria Geral do Estado, 1998, volumes I, II e III, tomos I e II.

SINGER, Paul. O uso do solo urbano na economia capitalista. Boletim Paulista de Geografia, AGB, n. ${ }^{\circ}$ 57, p. 77-99, dez. 1980 
SMOLKA, Martim e FURTADO, Fernanda (edit.). Recuperación de Plusvalias en América Latina. Eurelibros/Lincoln Institute of Land Policy/ Pontifícia Universidad Católica de Chile, 2001.

SMOLKA, Martim. Precio de la tierra y valorización inmobiliaria urbana: Esbozo para uma conceptualizacion del problema. RIAP XV, n. 60, p. 70-89, 1981.

SILVA, José Afonso da. Direito Urbanístico Brasileiro. 4 ed. São Paulo: Malheiros, 2006.

RT, 1982.

Aplicabilidade das Normas Constitucionais. $2^{\mathrm{a}}$ ed. São Paulo: Ed.

ZERBES, Marcelo Inda. Desapropriação e aspectos gerais da intervenção do Estado na propriedade privada . Jus Navigandi, Teresina, ano 11, n. 1294, 16 jan. 2007. Disponível em: <http://jus2.uol.com.br/doutrina/texto.asp?id=9394>. Acesso em: 16 nov. 2007 


\section{ANEXOS}

\section{DECRETO-LEI No 3.365, DE 21 DE JUNHO DE 1941.}

Dispõe sobre desapropriações por utilidade pública.

O Presidente da República, usando da atribuição que lhe confere o art. 180 da Constituição, decreta :

\section{DISPOSIÇÕES PRELIMINARES}

Art. $1^{\circ}$ A desapropriação por utilidade pública regular-se-á por esta lei, em todo o território nacional.

Art. $2^{\circ}$ Mediante declaração de utilidade pública, todos os bens poderão ser desapropriados pela União, pelos Estados, Municípios, Distrito Federal e Territórios.

$\S 1^{\circ}$ A desapropriação do espaço aéreo ou do subsolo só se tornará necessária, quando de sua utilização resultar prejuizo patrimonial do proprietário do solo.

$\S 2^{\circ}$ Os bens do domínio dos Estados, Municípios, Distrito Federal e Territórios poderão ser desapropriados pela União, e os dos Municípios pelos Estados, mas, em qualquer caso, ao ato deverá preceder autorização legislativa.

$\S 3^{\circ}$ É vedada a desapropriação, pelos Estados, Distrito Federal, Territórios e Municípios de ações, cotas e direitos representativos do capital de instituições e emprêsas cujo funcionamento dependa de autorização do Govêrno Federal e se subordine à sua fiscalização, salvo mediante prévia autorização, por decreto do Presidente da República. (Incluído pelo Decreto-lei no 856, de 1969)

Art. $3^{\circ}$ Os concessionários de serviços públicos e os estabelecimentos de carater público ou que exerçam funções delegadas de poder público poderão promover desapropriações mediante autorização expressa, constante de lei ou contrato.

Art. $4^{\circ}$ A desapropriação poderá abranger a área contígua necessária ao desenvolvimento da obra a que se destina, e as zonas que se valorizarem extraordinariamente, em consequência da realização do serviço. Em qualquer caso, a declaração de utilidade pública deverá compreendê-las, mencionando-se quais as indispensaveis à continuação da obra e as que se destinam à revenda.

Art. $5^{\circ}$ Consideram-se casos de utilidade pública:

a) a segurança nacional;

b) a defesa do Estado;

c) o socorro público em caso de calamidade;

d) a salubridade pública;

e) a criação e melhoramento de centros de população, seu abastecimento regular de meios de subsistência;

f) o aproveitamento industrial das minas e das jazidas minerais, das águas e da energia hidráulica;

g) a assistência pública, as obras de higiene e decoração, casas de saude, clínicas, estações de clima e fontes medicinais;

h) a exploração ou a conservação dos serviços públicos;

i) a abertura, conservação e melhøramento de vias ou logradouros públicos; a execução de planos de urbanização; o loteamento de terrenos edificados ou não para sua melhor utilização-econômica, higiênica ou estética;

i) a abertura, conservação e melhoramento de vias ou logradouros públicos; a execução de planos de urbanização; o loteamento de terreno, edificados ou não, para sua melhor utilização econômica, higiênica ou estética; a construção ou ampliação de distritos industriais. (Redação dada pela Lei no 6.602, de 1978)

i) a abertura, conservação e melhoramento de vias ou logradouros públicos; a execução de planos de urbanização; o parcelamento do solo, com ou sem edificação, para sua melhor utilização econômica, higiênica ou estética; a construção ou ampliação de distritos industriais; (Redação dada pela Lei n ${ }^{\circ}$ 9.785, de 1999)

j) o funcionamento dos meios de transporte coletivo;

k) a preservação e conservação dos monumentos históricos e artísticos, isolados ou integrados em conjuntos urbanos ou rurais, bem como as medidas necessárias a manter-lhes e realçar-lhes os aspectos mais valiosos ou característicos e, ainda, a proteção de paisagens e locais particularmente dotados pela natureza;

l) a preservação e a conservação adequada de arquivos, documentos e outros bens moveis de valor histórico ou artístico;

m) a construção de edifícios públicos, monumentos comemorativos e cemitérios;

n) a criação de estádios, aeródromos ou campos de pouso para aeronaves;

o) a reedição ou divulgação de obra ou invento de natureza científica, artística ou literária;

p) os demais casos previstos por leis especiais. 
$\S 1^{\circ}$ - A construção ou ampliação de distritos industriais, de que trata a alínea $i$ do caput deste artigo, inclui o loteamento das áreas necessárias à instalação de indústrias e atividades correlatas, bem como a revenda ou locação dos respectivos lotes a empresas previamente qualificadas. (Incluído pela Lei n 6.602, de 1978)

$\S 2^{\circ}$ - A efetivação da desapropriação para fins de criação ou ampliação de distritos industriais depende de aprovação, prévia e expressa, pelo Poder Público competente, do respectivo projeto de implantação". (Incluído pela Lei $n^{\circ} 6.602$, de 1978)

$\S 3^{\circ}$ Ao imóvel desapropriado para implantação de parcelamento popular, destinado às classes de menor renda, não se dará outra utilização nem haverá retrocessão. (Incluído pela Lei nº 9.785, de 1999)

Art. $6^{\circ}$ A declaração de utilidade pública far-se-á por decreto do Presidente da República, Governador, Interventor ou Prefeito.

Art. $7^{\circ}$ Declarada a utilidade pública, ficam as autoridades administrativas autorizadas a penetrar nos prédios compreendidos na declaração, podendo recorrer, em caso de oposição, ao auxílio de força policial.

Àquele que for molestado por excesso ou abuso de poder, cabe indenização por perdas e danos, sem prejuizo da ação penal.

Art. $8^{\circ}$ O Poder Legislativo poderá tomar a iniciativa da desapropriação, cumprindo, neste caso, ao Executivo, praticar os atos necessários à sua efetivação.

Art. $9^{\circ}$ Ao Poder Judiciário é vedado, no processo de desapropriação, decidir se se verificam ou não os casos de utilidade pública.

Art. 10. A desapropriação deverá efetivar-se mediante acordo ou intentar-se judicialmente, dentro de cinco anos, contados da data da expedição do respectivo decreto e findos os quais este caducará. (Vide Decreto-lei $\mathrm{n}^{\circ}$ 9.282, de 1946)

Parágrafo único. Extingue-se em cinco anos o direito de propor ação que vise a indenização por restrições decorrentes de atos do Poder Público. (Incluído pela Medida Provisória nº 2.183-56, de 2001)

Neste caso, somente decorrido um ano, poderá ser o mesmo bem objeto de nova declaração.

\section{DO PROCESSO JUDICIAL}

Art. 11. A ação, quando a União for autora, será proposta no Distrito Federal ou no foro da Capital do Estado onde for domiciliado o réu, perante o juizo privativo, se houver; sendo outro o autor, no foro da situação dos bens.

Art. 12. Somente os juizes que tiverem garantia de vitaliciedade, inamovibilidade e irredutibilidade de vencimentos poderão conhecer dos processos de desapropriação.

Art. 13. A petição inicial, alem dos requisitos previstos no Código de Processo Civil, conterá a oferta do preço e será instruida com um exemplar do contrato, ou do jornal oficial que houver publicado o decreto de desapropriação, ou cópia autenticada dos mesmos, e a planta ou descrição dos bens e suas confrontações.

Parágrafo único. Sendo o valor da causa igual ou inferior a dois contos de réis (2:000\$0), dispensam-se os autos suplementares.

Art. 14. Ao despachar a inicial, o juiz designará um perito de sua livre escolha, sempre que possivel, técnico, para proceder à avaliação dos bens.

Parágrafo único. O autor e o réu poderão indicar assistente técnico do perito.

Art. 15. Se o expropriante alegar urgência e depositar quantia arbitrada de conformidade com o art. 685 do Código de Processo Civil, o juiz mandará imití-lo provisoriamente na posse dos bens;

Parágrafo único. Mediante o depésito de quantia igual ao máximo da indenização prevista no parágrafo único do art. 27, a imissão de posse poderá dar se independente da citação do réu". (Incluído pelo Decreto lei $n^{\circ}$ 4.152, de de 1942)

Parágrafo único. Mediante depésito de quantia igual a máximo da indenização prevista no parágrafo único do art. 27, se a propriedade estiver sujeita ao impêsto predial, ou de quantia correspondente ao valor lançado para a cobrança ao impôsto territorial, urbano ou rural, proporcional à área exproprianda, a imissão de pөsse poderá dar-se independente da citação do réu. (Redação dada pelo Decreto-lei no 9.811, de 1946) $\underline{\text { (Revogado }}$ pela Lei no 2.786 , de 1956)

$\S 1^{\circ}$ A imissão provisória poderá ser feita, independente da citação do réu, mediante o depósito: (Incluído pela Lei $\mathrm{n}^{\circ} 2.786$, de 1956 )

a) do preço oferecido, se êste fôr superior a 20 (vinte) vêzes o valor locativo, caso o imóvel esteja sujeito ao impôsto predial; (Incluída pela Lei n ${ }^{\circ} 2.786$, de 1956)

b) da quantia correspondente a 20 (vinte) vêzes o valor locativo, estando o imóvel sujeito ao impôsto predial e sendo menor o preço oferecido; (Incluída pela Lei n 2.786, de 1956)

c) do valor cadastral do imóvel, para fins de lançamento do impôsto territorial, urbano ou rural, caso o referido valor tenha sido atualizado no ano fiscal imediatamente anterior; (Incluída pela Lei n ${ }^{\circ}$ 2.786, de 1956)

d) não tendo havido a atualização a que se refere o inciso c, o juiz fixará independente de avaliação, a importância do depósito, tendo em vista a época em que houver sido fixado originàlmente o valor cadastral e a valorização ou desvalorização posterior do imóvel. (Incluída pela Lei nº 2.786, de 1956) 
$\S 2^{\circ}$ A alegação de urgência, que não poderá ser renovada, obrigará o expropriante a requerer a imissão provisória dentro do prazo improrrogável de 120 (cento e vinte) dias. (Incluído pela Lei no 2.786, de 1956)

$\S 3^{\circ}$ Excedido o prazo fixado no parágrafo anterior não será concedida a imissão provisória. (Incluído pela Lei $\mathrm{n}^{\circ} 2.786$, de 1956)

Art. 15-A No caso de imissão prévia na posse, na desapropriação por necessidade ou utilidade pública e interesse social, inclusive para fins de reforma agrária, havendo divergência entre o preço ofertado em juízo e o valor do bem, fixado na sentença, expressos em termos reais, incidirão juros compensatórios de até seis por cento ao ano sobre o valor da diferença eventualmente apurada, a contar da imissão na posse, vedado o cálculo de juros compostos. (Incluído pela Medida Provisória nº 2.183-56, de 2001)

$\S 1^{\circ}$ Os juros compensatórios destinam-se, apenas, a compensar a perda de renda comprovadamente sofrida pelo proprietário. (Incluído pela Medida Provisória n 2.183-56, de 2001) (Vide ADIN n 2.332-2)

$\S 2^{\circ}$ Não serão devidos juros compensatórios quando o imóvel possuir graus de utilização da terra e de eficiência na exploração iguais a zero. (Incluído pela Medida Provisória $n^{\circ} 2.183-56$, de 2001) (Vide $^{\text {ADIN n }}{ }^{\circ}$ 2.332-2)

$\S 3^{\circ} \mathrm{O}$ disposto no caput deste artigo aplica-se também às ações ordinárias de indenização por apossamento administrativo ou desapropriação indireta, bem assim às ações que visem a indenização por restrições decorrentes de atos do Poder Público, em especial aqueles destinados à proteção ambiental, incidindo os juros sobre o valor fixado na sentença. (Incluído pela Medida Provisória $n^{\circ} 2.183-56$, de 2001)

$\S 4^{\circ}$ Nas ações referidas no $\S 3^{\circ}$, não será o Poder Público onerado por juros compensatórios relativos a período anterior à aquisição da propriedade ou posse titulada pelo autor da ação." (NR) (Incluído pela Medida Provisória $\mathrm{n}^{\circ} 2.183-56$, de 2001) (Vide ADIN n ${ }^{\circ} 2.332-2$ )

Art. 15-B Nas ações a que se refere o art. 15-A, os juros moratórios destinam-se a recompor a perda decorrente do atraso no efetivo pagamento da indenização fixada na decisão final de mérito, e somente serão devidos à razão de até seis por cento ao ano, a partir de $1^{\circ}$ de janeiro do exercício seguinte àquele em que o pagamento deveria ser feito, nos termos do art. 100 da Constituição. (Incluído pela Medida Provisória n ${ }^{\circ}$ 2.183$\underline{56, \text { de 2001) }}$

Art. 16. A citação far-se-á por mandado na pessoa do proprietário dos bens; a do marido dispensa a dá mulher; a de um sócio, ou administrador, a dos demais, quando o bem pertencer a sociedade; a do administrador da coisa no caso de condomínio, exceto o de edificio de apartamento constituindo cada um propriedade autonôma, a dos demais condôminos e a do inventariante, e, se não houver, a do cônjuge, herdeiro, ou legatário, detentor da herança, a dos demais interessados, quando o bem pertencer a espólio.

Parágrafo único. Quando não encontrar o citando, mas ciente de que se encontra no território da jurisdição do juiz, o oficial portador do mandado marcará desde logo hora certa para a citação, ao fim de 48 horas, independentemente de nova diligência ou despacho.

Art. 17. Quando a ação não for proposta no foro do domicilio ou da residência do réu, a citação far-se-á por precatória, se ó mesmo estiver em lugar certo, fora do território da jurisdição do juiz.

Art. 18. A citação far-se-á por edital se o citando não for conhecido, ou estiver em lugar ignorado, incerto ou inacessível, ou, ainda, no estrangeiro, o que dois oficiais do juizo certificarão.

Art. 19. Feita a citação, a causa seguirá com o rito ordinário.

Art. 20. A contestação só poderá versar sobre vício do processo judicial ou impugnação do preço; qualquer outra questão deverá ser decidida por ação direta.

Art. 21. A instância não se interrompe. No caso de falecimento do réu, ou perda de sua capacidade civil, o juiz, logo que disso tenha conhecimento, nomeará curador à lide, ate que se lhe habilite o interessado.

Parágrafo único. Os atos praticados da data do falecimento ou perda da capacidade à investidura do curador à lide poderão ser ratificados ou impugnados por ele, ou pelo representante do espólio, ou do incapaz.

Art. 22. Havendo concordância sobre o preço, o juiz o homologará por sentença no despacho saneador.

Art. 23. Findo o prazo para a contestação e não havendo concordância expressa quanto ao preço, o perito apresentará o laudo em cartório até cinco dias, pelo menos, antes da audiência de instrução e julgamento.

$\S 1^{\circ} \mathrm{O}$ perito poderá requisitar das autoridades públicas os esclarecimentos ou documentos que se tornarem necessários à elaboração do laudo, e deverá indicar nele, entre outras circunstâncias atendíveis para a fixação da indenização, as enumeradas no art. 27.

Ser-lhe-ão abonadas, como custas, as despesas com certidões e, a arbítrio do juiz, as de outros documentos que juntar ao laudo. laudo.

$\S 2^{\circ}$ Antes de proferido o despacho saneador, poderá o perito solicitar prazo especial para apresentação do

Art. 24. Na audiência de instrução e julgamento proceder-se-á na conformidade do Código de Processo Civil. Encerrado o debate, o juiz proferirá sentença fixando o preço da indenização.

Parágrafo único. Se não se julgar habilitado a decidir, o juiz designará desde logo outra audiência que se realizará dentro de 10 dias afim de publicar a sentença.

Art. 25. O principal e os acessórios serão computados em parcelas autônomas. 
Parágrafo único. O juiz poderá arbitrar quantia módica para desmonte e transporte de maquinismos instalados e em funcionamento.

Art. 26. No valor da indenização, que será contemperâneo da declaração de utilidade pública, não- se

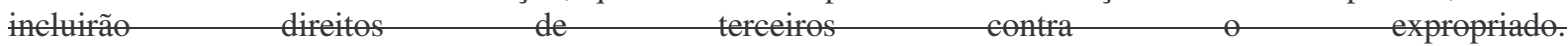

Parágrafo único. Serão atendidas as benfeitorias necessárias feitas apés a desapropriação; as uteis, quande feitas com autorização do expropriante.

Art. 26. No valor da indenização, que será contemporâneo da avaliação, não se incluirão os direitos de terceiros contra o expropriado. (Redação dada pela Lei n ${ }^{\circ} 2.786$, de 1956)

Parágrafo único. Serão atendidas as benfeitorias necessárias feitas após a desapropriação; as úteis, quando feitas com alterização do expropriante. (Redação dada pela Lei n $n^{\circ} 2.786$, de 1956 )

$\S 1^{\circ}$ Serão atendidas as benfeitorias necessárias feitas após a desapropriação; as úteis, quando feitas com autorização do expropriante. (Renumerado do Parágrafo Único pela Lei n ${ }^{\circ} 4.686$, de 1965)

$\S 2^{\circ}$ Decorrido prazo superior a um ano a partir da avaliação, $\theta$ Juiz ow 0 Tribunal, antes da decisão finat, determinará a correção monetária do valor apurado. (Incluído pela Lei no 4.686 , de 1965)

$\S 2^{\circ}$ Decorrido prazo superior a um ano a partir da avaliação, o Juiz ou Tribunal, antes da decisão final, determinará a correção monetária do valor apurado, conforme índice que será fixado, trimestralmente, pela Secretaria de Planejamento da Presidência da República. (Redação dada pela Lei n ${ }^{\circ}$ 6.306, de 1978)

Art. 27. O juiz indicará na sentença os fatos que motivaram o seu convencimento e deverá atender, especialmente, à estimação dos bens para efeitos fiscais; ao preço de aquisição e interesse que deles aufere o proprietário; à sua situação, estado de conservação e segurança; ao valor venal dos da mesma espécie, nos últimos cinco anos, e à valorização ou depreciação de área remanescente, pertencente ao réu.

Parágrafo único. Se a propriedade estiver sujeita ao imposto predial, o "quantum" da indenização não será inferior a 10 , nem superior a 20 vezes o valor locativo, deduzida previamente a importância do imposto, e tendo por base esse mesmo imposto, lançado no ano anterior ao decreto de desapropriação. (Revogado pela Lei $\mathrm{n}^{\circ}$ 2.786, de 1956)

$\S 1^{\circ} \Lambda$ sentença que fixar 0 valor da indenização quando êste fôr superior ao preço- oferecido, condenará $\Theta$ desapropriante a pagar honørários de advogado, sêbre o valor da diferença. (Incluído pela Lei no 2.786 , de 1956)

$\S 1^{\circ}$ A sentença que fixar o valor da indenização quando este for superior ao preço oferecido condenará o desapropriante a pagar honorários do advogado, que serão fixados entre meio e cinco por cento do valor da diferença, observado o disposto no $\S 4^{\circ}$ do art. 20 do Código de Processo Civil, não podendo os honorários ultrapassar R \$ 151.000,00 (cento e cinqüenta e um mil reais). (Redação dada Medida Provisória $n^{\circ} 2.183-56$, de 2001) (Vide ADIN n².332-2)

$\S 2^{\circ}$ A transmissão da propriedade, decorrente de desapropriação amigável ou judicial, não ficará sujeita ao impôsto de lucro imobiliário. (Incluído pela Lei $\mathrm{n}^{\circ} 2.786$, de 1956)

$\S 3^{\circ} \mathrm{O}$ disposto no $\S 1^{\circ}$ deste artigo se aplica: (Incluído pela Medida Provisória ${ }^{\circ}$ 2.183-56, de 2001)

I - ao procedimento contraditório especial, de rito sumário, para o processo de desapropriação de imóvel rural, por interesse social, para fins de reforma agrária; (Incluído pela Medida Provisória nº 2.183-56, de 2001)

II - às ações de indenização por apossamento administrativo ou desapropriação indireta. (Incluído pela Medida Provisória n $2.183-56$, de 2001)

$\S 4^{\circ} \mathrm{O}$ valor a que se refere o $\S 1^{\circ}$ será atualizado, a partir de maio de 2000 , no dia $1^{\circ}$ de janeiro de cada ano, com base na variação acumulada do Índice de Preços ao Consumidor Amplo - IPCA do respectivo período. (Incluído pela Medida Provisória nº 2.183-56, de 2001)

Art. 28. Da sentença que fixar o preço da indenização caberá apelação com efeito simplesmente devolutivo, quando interposta pelo expropriado, e com ambos os efeitos, quando o for pelo expropriante.

$\S 1^{\ominus}-O$ juiz recorrerá ex officio quando condenar a Fazenda Pública em quantia superior ao dobro da өferecida.

$\S 1^{\circ}$ A sentença que condenar a Fazenda Pública em quantia superior ao dobro da oferecida fica sujeita ao duplo grau de jurisdição. (Redação dada pela Lei $n^{\circ}$ 6.071, de 1974)

$\S 2^{\circ}$ Nas causas de valor igual ou inferior a dois contos de réis (2:000\$0), observar-se-á o disposto no art. 839 do Código de Processo Civil.

Art. 29. Efetuado o pagamento ou a consignação, expedir-se-á, em favor do expropriante, mandado de imissão de posse, valendo a sentença como título habil para a transcrição no registro de imoveis.

Art. 30. As custas serão pagas pelo autor se o réu aceitar o preço oferecido; em caso contrário, pelo vencido, ou em proporção, na forma da lei.

\section{DISPOSIÇÕES FINAIS}

Art. 31. Ficam subrogados no preço quaisquer onus ou direitos que recaiam sobre o bem expropriado.

Art. 32. O pagamento do preço será feito em moeda corrente. Mas, havendo autorização prévia do Poder Legislativo em cada caso, poderá efetuar se em títulos da dívida pública federal, admitides em bolsa, de acorde com a cotação do dia anterior ao do depésito.

Art. 32. O pagamento do preço será prévio e em dinheiro. (Redação dada pela Lei no 2.786 , de 1956) 
Art. 33. O depósito do preço fixado por sentença, à disposição do juiz da causa, é considerado pagamento prévio da indenização.

Parágrafo único. O depésito far se á no Banco do Brasil ou, onde este não tiver agência, em estabelecimento bancário acreditado, a critério do juiz.

$\S 1^{\circ} \mathrm{O}$ depósito far-se-á no Banco do Brasil ou, onde este não tiver agência, em estabelecimento bancário acreditado, a critério do juiz. (Renumerado do Parágrafo Único pela Lei no 2.786, de 1956)

$\S 2^{\circ} \mathrm{O}$ desapropriado, ainda que discorde do preço oferecido, do arbitrado ou do fixado pela sentença, poderá levantar até $80 \%$ (oitenta por cento) do depósito feito para o fim previsto neste e no art. 15, observado o processo estabelecido no art. 34. (Incluído pela Lei n ${ }^{\circ} 2.786$, de 1956)

Art. 34. O levantamento do preço será deferido mediante prova de propriedade, de quitação de dívidas fiscais que recaiam sobre o bem expropriado, e publicação de editais, com o prazo de 10 dias, para conhecimento de terceiros.

Parágrafo único. Se o juiz verificar que há dúvida fundada sobre o domínio, o preço ficará em depósito, ressalvada aos interessados a ação própria para disputá-lo.

Art. 35. Os bens expropriados, uma vez incorporados à Fazenda Pública, não podem ser objeto de reivindicação, ainda que fundada em nulidade do processo de desapropriação. Qualquer ação, julgada procedente, resolver-se-á em perdas e danos.

Art. 36. É permitida a ocupação temporária, que será indenizada, afinal, por ação própria, de terrenos não edificados, vizinhos às obras e necessários à sua realização.

O expropriante prestará caução, quando exigida.

Art. 37. Aquele cujo bem for prejudicado extraordinariamente em sua destinação econômica pela desapropriação de áreas contíguas terá direito a reclamar perdas e danos do expropriante.

Art. 38. O réu responderá perante terceiros, e por ação própria, pela omissão ou sonegação de quaisquer informações que possam interessar à marcha do processo ou ao recebimento da indenização.

Art. 39. A ação de desapropriação pode ser proposta durante as férias forenses, e não se interrompe pela superveniência destas.

Art. 40. O expropriante poderá constituir servidões, mediante indenização na forma desta lei.

Art. 41. As disposições desta lei aplicam-se aos processos de desapropriação em curso, não se permitindo depois de sua vigência outros termos e atos além dos por ela admitidos, nem o seu processamento por forma diversa da que por ela é regulada.

Art. 42. No que esta lei for omissa aplica-se o Código de Processo Civil.

Art. 43. Esta lei entrará em vigor 10 dias depois de publicada, no Distrito Federal, e 30 dias no Estados e Território do Acre, revogadas as disposições em contrário.

Rio de Janeiro, em 21 junho de $1941,120^{\circ}$ da Independência e $53^{\circ}$ da República.

GETULIOVARGAS

Francisco Campos.

Este texto não substitui o publicado no D.O.U. de 18.7.1941 
LEI No 4.132, DE 10 DE SETEMBRO DE 1962.

Define os casos de desapropriação por interesse social e dispõe sobre sua aplicação.

O PRESIDENTE DA REPÚBLICA, Faço saber que o Congresso Nacional decreta e eu sanciono a seguinte lei:

Art. $1^{\circ}$ A desapropriação por interesse social será decretada para promover a justa distribuição da propriedade ou condicionar o seu uso ao bem estar social, na forma do art. 147 da Constituição Federal.

Art. $2^{\circ}$ Considera-se de interesse social:

I - o aproveitamento de todo bem improdutivo ou explorado sem correspondência com as necessidades de habitação, trabalho e consumo dos centros de população a que deve ou possa suprir por seu destino econômico;

II - a instalação ou a intensificação das culturas nas áreas em cuja exploração não se obedeça a plano de zoneamento agrícola, VETADO;

III - o estabelecimento e a manutenção de colônias ou cooperativas de povoamento e trabalho agrícola:

IV - a manutenção de posseiros em terrenos urbanos onde, com a tolerância expressa ou tácita do proprietário, tenham construído sua habilitação, formando núcleos residenciais de mais de 10 (dez) famílias;

V - a construção de casa populares;

VI - as terras e águas suscetíveis de valorização extraordinária, pela conclusão de obras e serviços públicos, notadamente de saneamento, portos, transporte, eletrificação armazenamento de água e irrigação, no caso em que não sejam ditas áreas socialmente aproveitadas;

VII - a proteção do solo e a preservação de cursos e mananciais de água e de reservas florestais.

VIII - a utilização de áreas, locais ou bens que, por suas características, sejam apropriados ao desenvolvimento de atividades turísticas. (Incluído pela Lei $n^{\circ} 6.513$, de 20.12.77)

$\S 1^{\circ} \mathrm{O}$ disposto no item I deste artigo só se aplicará nos casos de bens retirados de produção ou tratando-se de imóveis rurais cuja produção, por ineficientemente explorados, seja inferior à média da região, atendidas as condições naturais do seu solo e sua situação em relação aos mercados.

$\S 2^{\circ}$ As necessidades de habitação, trabalho e consumo serão apuradas anualmente segundo a conjuntura e condições econômicas locais, cabendo o seu estudo e verificação às autoridades encarregadas de velar pelo bem estar e pelo abastecimento das respectivas populações.

Art. $3^{\circ} \mathrm{O}$ expropriante tem o prazo de 2 (dois) anos, a partir da decretação da desapropriação por interesse social, para efetivar a aludida desapropriação e iniciar as providências de aproveitamento do bem expropriado.

Parágrafo único. VETADO.

Art. $4^{\circ}$ Os bens desapropriados serão objeto de venda ou locação, a quem estiver em condições de dar-lhes a destinação social prevista.

Art. $5^{\circ}$ No que esta lei for omissa aplicam-se as normas legais que regulam a desapropriação por unidade pública, inclusive no tocante ao processo e à justa indenização devida ao proprietário.

Art. $6^{\circ}$ Revogam-se as disposições em contrário.

Brasília, 10 de setembro de $1962 ; 141^{\circ}$ da Independência e $74^{\circ}$ da República.

JOÃO GOULART

Este texto não substitui o publicado no D.O.U. de 7.11.1962 


\section{LEI No 8.629, DE 25 DE FEVEREIRO DE 1993.}

Dispõe sobre a regulamentação dos dispositivos constitucionais relativos à reforma agrária, previstos no Capítulo III, Título VII, da

Constituição Federal

O PRESIDENTE DA REPÚBLICA Faço saber que o Congresso Nacional decreta e eu sanciono a seguinte lei:

Art. $1^{\circ}$ Esta lei regulamenta e disciplina disposições relativas à reforma agrária, previstas no Capítulo III, Título VII, da Constituição Federal.

Art. $2^{\circ}$ A propriedade rural que não cumprir a função social prevista no art. $9^{\circ}$ é passível de desapropriação, nos termos desta lei, respeitados os dispositivos constitucionais.

$\S 1^{\circ}$ Compete à União desapropriar por interesse social, para fins de reforma agrária, o imóvel rural que não esteja cumprindo sua função social.

$\S 2^{\circ}$ Para fins deste artigo, fica a União, através do órgão federal competente, altorizada a ingressar ne imóvel de propriedade particular, para levantamento de dados e informaçẽes, com prévia notificação.

$\S 2^{\circ}$ Para os fins deste artigo, fica a União, através do órgão federal competente, autorizada a ingressar no imóvel de propriedade particular para levantamento de dados e informações, mediante prévia comunicação escrita ao proprietário, preposto ou seu representante. (Redação dada pela Medida Provisória $n^{\circ}$ 2.183-56, de $\underline{2001)}$

$\S 3^{\circ} \mathrm{Na}$ ausência do proprietário, do preposto ou do representante, a comunicação será feita mediante edital, a ser publicado, por três vezes consecutivas, em jornal de grande circulação na capital do Estado de localização do imóvel. (Incluído pela Medida Provisória nº 2.183-56, de 2001)

$\S 4^{\circ}$ Não será considerada, para os fins desta Lei, qualquer modificação, quanto ao domínio, à dimensão e às condições de uso do imóvel, introduzida ou ocorrida até seis meses após a data da comunicação para levantamento de dados e informações de que tratam os $\S \S 2^{\circ}$ e $3^{\circ}$. (Incluído pela Medida Provisória $n^{\circ} 2.183-56$, de 2001)

$\S 5^{\circ}$ No caso de fiscalização decorrente do exercício de poder de polícia, será dispensada a comunicação de que tratam os $\S \S 2^{\circ}$ e $3^{\circ}$. (Incluído pela Medida Provisória $n^{\circ} 2.183-56$, de 2001)

$\S 6^{\circ}$ O imóvel rural de domínio público ou particular objeto de esbulho possessório ou invasão motivada por conflito agrário ou fundiário de caráter coletivo não será vistoriado, avaliado ou desapropriado nos dois anos seguintes à sua desocupação, ou no dobro desse prazo, em caso de reincidência; e deverá ser apurada a responsabilidade civil e administrativa de quem concorra com qualquer ato omissivo ou comissivo que propicie o descumprimento dessas vedações. (Incluído pela Medida Provisória nº 2.183-56, de 2001)

$\S 7^{\circ}$ Será excluído do Programa de Reforma Agrária do Governo Federal quem, já estando beneficiado com lote em Projeto de Assentamento, ou sendo pretendente desse benefício na condição de inscrito em processo de cadastramento e seleção de candidatos ao acesso à terra, for efetivamente identificado como participante direto ou indireto em conflito fundiário que se caracterize por invasão ou esbulho de imóvel rural de domínio público ou privado em fase de processo administrativo de vistoria ou avaliação para fins de reforma agrária, ou que esteja sendo objeto de processo judicial de desapropriação em vias de imissão de posse ao ente expropriante; e bem assim quem for efetivamente identificado como participante de invasão de prédio público, de atos de ameaça, sequiestro ou manutenção de servidores públicos e outros cidadãos em cárcere privado, ou de quaisquer outros atos de violência real ou pessoal praticados em tais situações. (Incluído pela Medida Provisória n 2.18356, de 2001)

$\S 8^{\circ}$ A entidade, a organização, a pessoa jurídica, o movimento ou a sociedade de fato que, de qualquer forma, direta ou indiretamente, auxiliar, colaborar, incentivar, incitar, induzir ou participar de invasão de imóveis rurais ou de bens públicos, ou em conflito agrário ou fundiário de caráter coletivo, não receberá, a qualquer título, recursos públicos. (Incluído pela Medida Provisória nº 2.183-56, de 2001)

$\S 9^{\circ}$ Se, na hipótese do $\S 8^{\circ}$, a transferência ou repasse dos recursos públicos já tiverem sido autorizados, assistirá ao Poder Público o direito de retenção, bem assim o de rescisão do contrato, convênio ou instrumento similar. (Incluído pela Medida Provisória n n $^{2.183-56, ~ d e ~ 2001) ~}$

Art. $2^{\circ}$-A. Na hipótese de fraude ou simulação de esbulho ou invasão, por parte do proprietário ou legítimo possuidor do imóvel, para os fins dos $\S \S 6^{\circ}$ e $7^{\circ}$ do art. $2^{\circ}$, o órgão executor do Programa Nacional de Reforma Agrária aplicará pena administrativa de $\mathrm{R} \$ 55.000,00$ (cinquienta e cinco mil reais) a $\mathrm{R} \$ 535.000,00$ (quinhentos e trinta e cinco mil reais) e o cancelamento do cadastro do imóvel no Sistema Nacional de Cadastro Rural, sem prejuízo das demais sanções penais e civis cabíveis. (Incluído pela Medida Provisória n 2.183-56, de 2001)

Parágrafo único. Os valores a que se refere este artigo serão atualizados, a partir de maio de 2000 , no dia $1^{\circ}$ de janeiro de cada ano, com base na variação acumulada do Índice Geral de Preços - Disponibilidade Interna IGP-DI, da Fundação Getúlio Vargas, no respectivo período. (Incluído pela Medida Provisória n 2.183-56, de $\underline{2001)}$ 
Art. $3^{\circ}(\underline{\text { Vetado }})$

$\S 1^{\circ}$ (Vetado $)$

$\S 2^{\circ}$ (Vetado $)$

Art. $4^{\circ}$ Para os efeitos desta lei, conceituam-se:

I - Imóvel Rural - o prédio rústico de área contínua, qualquer que seja a sua localização, que se destine ou possa se destinar à exploração agrícola, pecuária, extrativa vegetal, florestal ou agro-industrial;

II - Pequena Propriedade - o imóvel rural:

a) de área compreendida entre 1 (um) e 4 (quatro) módulos fiscais;

b) $(\underline{\text { Vetado }})$

c) $($ Vetado $)$

III - Média Propriedade - o imóvel rural:

a) de área superior a 4 (quatro) e até 15 (quinze) módulos fiscais;

b) (Vetado)

Parágrafo único. São insuscetíveis de desapropriação para fins de reforma agrária a pequena e a média propriedade rural, desde que o seu proprietário não possua outra propriedade rural.

Art. $5^{\circ}$ A desapropriação por interesse social, aplicável ao imóvel rural que não cumpra sua função social, importa prévia e justa indenização em títulos da dívida agrária.

$\S 1^{\circ}$ As benfeitorias úteis e necessárias serão indenizadas em dinheiro.

$\S 2^{\circ} \mathrm{O}$ decreto que declarar o imóvel como de interesse social, para fins de reforma agrária, autoriza a União a propor ação de desapropriação.

$\S 3^{\circ}$ Os títulos da dívida agrária, que conterão cláusula assecuratória de preservação de seu valor real, serão resgatáveis a partir do segundo ano de sua emissão, em percentual proporcional ao prazo, observados os seguintes critérios:

I- do segundo ao quinto ano, quando emitidos para indenização de imóveis com área inferior a 40 (quarenta) módulos fiscais;

II do segundo ao décimo ano, quando emitidos para indenização de imóvel com área acima de 40 (quarenta) até 70 (setenta) módulos fiscais;

III do segundo ao décimo quinto ano, quando emitidos para indenização de imóvel com área acima de 70 (setenta) até 150 (cento e cinqüienta) módulos fiscais;

IV do segundo ao vigésimo ano, quando emitides para indenização de imóvel com área superior a 150 (cento e cinqüienta) módulos fiscais.

I - do segundo ao décimo quinto ano, quando emitidos para indenização de imóvel com área de até setenta módulos fiscais; (Redação dada pela Medida Provisória n 2.183-56, de 2001)

II - do segundo ao décimo oitavo ano, quando emitidos para indenização de imóvel com área acima de setenta e até cento e cinqüenta módulos fiscais; e (Redação dada pela Medida Provisória n 2.183-56, de 2001)

III - do segundo ao vigésimo ano, quando emitidos para indenização de imóvel com área superior a cento e cinqüienta módulos fiscais. (Redação dada pela Medida Provisória n ${ }^{\circ} 2.183-56$, de 2001)

$\S 4^{\circ}$ No caso de aquisição por compra e venda de imóveis rurais destinados à implantação de projetos integrantes do Programa Nacional de Reforma Agrária, nos termos desta Lei e da Lei $n^{0} 4.504$, de 30 de novembro de 1964, e os decorrentes de acordo judicial, em audiência de conciliação, com o objetivo de fixar a prévia e justa indenização, a ser celebrado com a União, bem como com os entes federados, o pagamento será efetuado de forma escalonada em Títulos da Dívida Agrária - TDA, resgatáveis em parcelas anuais, iguais e sucessivas, a partir do segundo ano de sua emissão, observadas as seguintes condições: (Incluído pela Medida Provisória $n^{\circ}$ 2.183-56, de 2001)

I - imóveis com área de até três mil hectares, no prazo de cinco anos; (Incluído pela Medida Provisória $n^{\circ}$ 2.183-56, de 2001)

II - imóveis com área superior a três mil hectares: (Incluído pela Medida Provisória n 2.183-56, de 2001)

a) o valor relativo aos primeiros três mil hectares, no prazo de cinco anos; (Incluído pela Medida Provisória $\underline{\mathrm{n}^{\circ} 2.183-56, \text { de 2001) }}$

b) o valor relativo à área superior a três mil e até dez mil hectares, em dez anos; (Incluído pela Medida Provisória $\mathrm{n}^{\mathrm{o}} 2.183-56$, de 2001)

c) o valor relativo à área superior a dez mil hectares até quinze mil hectares, em quinze anos; e (Incluído pela Medida Provisória no 2.183-56, de 2001)

d) o valor da área que exceder quinze mil hectares, em vinte anos. (Incluído pela Medida Provisória $\mathrm{n}^{\circ}$ $\underline{2.183-56, \text { de 2001) }}$

$\S 5^{\circ}$ Os prazos previstos no $\S 4^{\circ}$, quando iguais ou superiores a dez anos, poderão ser reduzidos em cinco anos, desde que o proprietário concorde em receber o pagamento do valor das benfeitorias úteis e necessárias integralmente em TDA. (Incluído pela Medida Provisória nº 2.183-56, de 2001) 
$\S 6^{\circ}$ Aceito pelo proprietário o pagamento das benfeitorias úteis e necessárias em TDA, os prazos de resgates dos respectivos títulos serão fixados mantendo-se a mesma proporcionalidade estabelecida para aqueles relativos ao valor da terra e suas acessões naturais. (Incluído pela Medida Provisória n ${ }^{\circ}$ 2.183-56, de 2001)

Art. $6^{\circ}$ Considera-se propriedade produtiva aquela que, explorada econômica e racionalmente, atinge, simultaneamente, graus de utilização da terra e de eficiência na exploração, segundo índices fixados pelo órgão federal competente.

$\S 1^{\circ} \mathrm{O}$ grau de utilização da terra, para efeito do caput deste artigo, deverá ser igual ou superior a $80 \%$ (oitenta por cento), calculado pela relação percentual entre a área efetivamente utilizada e a área aproveitável total do imóvel.

$\S 2^{\circ} \mathrm{O}$ grau de eficiência na exploração da terra deverá ser igual ou superior a $100 \%$ (cem por cento), e será obtido de acordo com a seguinte sistemática:

I - para os produtos vegetais, divide-se a quantidade colhida de cada produto pelos respectivos índices de rendimento estabelecidos pelo órgão competente do Poder Executivo, para cada Microrregião Homogênea;

II - para a exploração pecuária, divide-se o número total de Unidades Animais (UA) do rebanho, pelo índice de lotação estabelecido pelo órgão competente do Poder Executivo, para cada Microrregião Homogênea;

III - a soma dos resultados obtidos na forma dos incisos I e II deste artigo, dividida pela área efetivamente utilizada e multiplicada por 100 (cem), determina o grau de eficiência na exploração.

$\S 3^{\circ}$ Considera-se efetivamente utilizadas:

I - as áreas plantadas com produtos vegetais;

II - as áreas de pastagens nativas e plantadas, observado o índice de lotação por zona de pecuária, fixado pelo Poder Executivo;

III - as áreas de exploração extrativa vegetal ou florestal, observados os índices de rendimento estabelecidos pelo órgão competente do Poder Executivo, para cada Microrregião Homogênea, e a legislação ambiental;

IV - as áreas de exploração de florestas nativas, de acordo com plano de exploração e nas condições estabelecidas pelo órgão federal competente;

$\checkmark$ as áreas sob processos técnices de formação ou recuperação de pastagens ou de culturas permanentes

V - as áreas sob processos técnicos de formação ou recuperação de pastagens ou de culturas permanentes, tecnicamente conduzidas e devidamente comprovadas, mediante documentação e Anotação de Responsabilidade Técnica. (Redação dada pela Medida Provisória nº 2.183-56, de 2001)

$\S 4^{\circ}$ No caso de consórcio ou intercalação de culturas, considera-se efetivamente utilizada a área total do consórcio ou intercalação.

$\S 5^{\circ}$ No caso de mais de um cultivo no ano, com um ou mais produtos, no mesmo espaço, considera-se efetivamente utilizada a maior área usada no ano considerado.

$\S 6^{\circ}$ Para os produtos que não tenham índices de rendimentos fixados, adotar-se-á a área utilizada com esses produtos, com resultado do cálculo previsto no inciso I do $\S 2^{\circ}$ deste artigo.

$\S 7^{\circ}$ Não perderá a qualificação de propriedade produtiva o imóvel que, por razões de força maior, caso fortuito ou de renovação de pastagens tecnicamente conduzida, devidamente comprovados pelo órgão competente, deixar de apresentar, no ano respectivo, os graus de eficiência na exploração, exigidos para a espécie.

$\S 8^{\circ}$ São garantidos os incentivos fiscais referentes ao Imposto Territorial Rural relacionados com os graus de utilização e de eficiência na exploração, conforme o disposto no art. 49 da Lei no 4.504, de 30 de novembro de 1964.

Art. $7^{\circ}$ Não será passível de desapropriação, para fins de reforma agrária, o imóvel que comprove estar sendo objeto de implantação de projeto técnico que atenda aos seguintes requisitos:

I - seja elaborado por profissional legalmente habilitado e identificado;

II - esteja cumprindo o cronograma físico-financeiro originalmente previsto, não admitidas prorrogações dos prazos;

III - preveja que, no mínimo, $80 \%$ (oitenta por cento) da área total aproveitável do imóvel seja efetivamente utilizada em, no máximo, 3 (três) anos para as culturas anuais e 5 (cinco) anos para as culturas permanentes;

IV - haja sido registrado no órgão competente no mínimo 6 (seis) meses antes do decreto declaratório de interesse social

IV - haja sido aprovado pelo órgão federal competente, na forma estabelecida em regulamento, no mínimo seis meses antes da comunicação de que tratam os $\S \S 2^{\circ}$ e $3^{\circ}$ do art. $2^{\circ}$. (Redação dada pela Medida Provisória $n^{\circ}$ $\underline{2.183-56, \text { de 2001) }}$

Parágrafo único. Os prazos previstos no inciso III deste artigo poderão ser prorrogados em até 50\% (cinqüenta por cento), desde que o projeto receba, anualmente, a aprovação do órgão competente para fiscalização e tenha sua implantação iniciada no prazo de 6 (seis) meses, contado de sua aprovação.

Art. $8^{\circ}$ Ter-se-á como racional e adequado o aproveitamento de imóvel rural, quando esteja oficialmente destinado à execução de atividades de pesquisa e experimentação que objetivem o avanço tecnológico da agricultura. 
Parágrafo único. Para os fins deste artigo só serão consideradas as propriedades que tenham destinados às atividades de pesquisa, no mínimo, 80\% (oitenta por cento) da área total aproveitável do imóvel, sendo consubstanciadas tais atividades em projeto:

I - adotado pelo Poder Público, se pertencente a entidade de administração direta ou indireta, ou a empresa sob seu controle;

II - aprovado pelo Poder Público, se particular o imóvel.

Art. $9^{\circ}$ A função social é cumprida quando a propriedade rural atende, simultaneamente, segundo graus e critérios estabelecidos nesta lei, os seguintes requisitos:

I - aproveitamento racional e adequado;

II - utilização adequada dos recursos naturais disponíveis e preservação do meio ambiente;

III - observância das disposições que regulam as relações de trabalho;

IV - exploração que favoreça o bem-estar dos proprietários e dos trabalhadores.

$\S 1^{\circ}$ Considera-se racional e adequado o aproveitamento que atinja os graus de utilização da terra e de eficiência na exploração especificados nos $\S \S 1^{\circ}$ a $7^{\circ}$ do art. $6^{\circ}$ desta lei.

$\S 2^{\circ}$ Considera-se adequada a utilização dos recursos naturais disponíveis quando a exploração se faz respeitando a vocação natural da terra, de modo a manter o potencial produtivo da propriedade.

$\S 3^{\circ}$ Considera-se preservação do meio ambiente a manutenção das características próprias do meio natural e da qualidade dos recursos ambientais, na medida adequada à manutenção do equilíbrio ecológico da propriedade e da saúde e qualidade de vida das comunidades vizinhas.

$\S 4^{\circ}$ A observância das disposições que regulam as relações de trabalho implica tanto o respeito às leis trabalhistas e aos contratos coletivos de trabalho, como às disposições que disciplinam os contratos de arrendamento e parceria rurais.

$\S 5^{\circ}$ A exploração que favorece o bem-estar dos proprietários e trabalhadores rurais é a que objetiva o atendimento das necessidades básicas dos que trabalham a terra, observa as normas de segurança do trabalho e não provoca conflitos e tensões sociais no imóvel.

$\S 6^{\circ}$ (Vetado. $)$

Art. 10. Para efeito do que dispõe esta lei, consideram-se não aproveitáveis:

I - as áreas ocupadas por construções e instalações, excetuadas aquelas destinadas a fins produtivos, como estufas, viveiros, sementeiros, tanques de reprodução e criação de peixes e outros semelhantes;

II - as áreas comprovadamente imprestáveis para qualquer tipo de exploração agrícola, pecuária, florestal ou extrativa vegetal;

III - as áreas sob efetiva exploração mineral;

IV - as áreas de efetiva preservação permanente e demais áreas protegidas por legislação relativa à conservação dos recursos naturais e à preservação do meio ambiente.

Art. 11. Os parâmetros, índices e indicadores que informam o conceito de produtividade serão ajustados, periodicamente, de modo a levar em conta o progresso científico e tecnológico da agricultura e $\theta$ desenvolvimento regional, pelo Ministério da Agricultura e Reforma Agrária, ouvido o Conselho Nacional de Política Agrícola.

Art. 12. Considera se justa a indenização que permita a desapropriado a repesição, em seu patrimônio, de valor do bem que perdeu por interesse social.

$\S 1^{\circ} \Lambda$ identificação do valor do bem a ser indenizado será feita, preferencialmente, com base nos seguintes referenciais técnices e mercadológicos, entre outros usualmente empregados:

I valor das benfeiterias úteis e necessárias, descontada a depreciação conforme o estado de conservação;

II- valor da terra nua, observados os seguintes aspectos:

a) localização do imóvel;

b) capacidade potencial da terra;

c) dimensão do imóvel.

$\S 2^{\circ}$ Os dados referentes ao preço das benfeitorias e do hectare da terra nua a serem indenizados serão levantados junto às Prefeituras Municipais, órgãos estaduais encarregados de avaliação imobiliária, quando houver, Tabelionatos e Cartórios de Registro de Imóveis, e através de pesquisa de mercado.

Art. 11. Os parâmetros, índices e indicadores que informam o conceito de produtividade serão ajustados, periodicamente, de modo a levar em conta o progresso científico e tecnológico da agricultura e o desenvolvimento regional, pelos Ministros de Estado do Desenvolvimento Agrário e da Agricultura e do Abastecimento, ouvido o Conselho Nacional de Política Agrícola. (Redação dada Medida Provisória nº 2.183$\underline{56, \text { de 2001) }}$

Art. 12. Considera-se justa a indenização que reflita o preço atual de mercado do imóvel em sua totalidade, aí incluídas as terras e acessões naturais, matas e florestas e as benfeitorias indenizáveis, observados os seguintes aspectos: (Redação dada Medida Provisória n 2.183-56, de 2001)

I - localização do imóvel; (Incluído dada Medida Provisória no 2.183-56, de 2001)

II - aptidão agrícola; (Incluído dada Medida Provisória no 2.183-56, de 2001) 
III - dimensão do imóvel; (Incluído dada Medida Provisória n ${ }^{\circ}$ 2.183-56, de 2001)

IV - área ocupada e ancianidade das posses; (Incluído dada Medida Provisória $\mathrm{n}^{\circ} 2.183-56$, de 2001)

$\mathrm{V}$ - funcionalidade, tempo de uso e estado de conservação das benfeitorias. (Incluído dada Medida Provisória ${ }^{\circ} 2.183-56$, de 2001)

$\S 1^{\circ}$ Verificado o preço atual de mercado da totalidade do imóvel, proceder-se-á à dedução do valor das benfeitorias indenizáveis a serem pagas em dinheiro, obtendo-se o preço da terra a ser indenizado em TDA. (Redação dada Medida Provisória n $2.183-56$, de 2001)

$\S 2^{\circ}$ Integram o preço da terra as florestas naturais, matas nativas e qualquer outro tipo de vegetação natural, não podendo o preço apurado superar, em qualquer hipótese, o preço de mercado do imóvel. (Redação dada Medida Provisória n n $^{\circ} .183-56$, de 2001)

$\S 3^{\circ}$ O Laudo de Avaliação será subscrito por Engenheiro Agrônomo com registro de Anotação de Responsabilidade Técnica - ART, respondendo o subscritor, civil, penal e administrativamente, pela superavaliação comprovada ou fraude na identificação das informações. (Incluído dada Medida Provisória ${ }^{\circ}$ $\underline{2.183-56, \text { de 2001) }}$

Art. 13. As terras rurais de domínio da União, dos Estados e dos Municípios ficam destinadas, preferencialmente, à execução de planos de reforma agrária.

Parágrafo único. Excetuando-se as reservas indígenas e os parques, somente se admitirá a existência de imóveis rurais de propriedade pública, com objetivos diversos dos previstos neste artigo, se o poder público os explorar direta ou indiretamente para pesquisa, experimentação, demonstração e fomento de atividades relativas ao desenvolvimento da agricultura, pecuária, preservação ecológica, áreas de segurança, treinamento militar, educação de todo tipo, readequação social e defesa nacional.

Art. 14. (Vetado.)

Art. 15. (Vetado.)

Art. 16. Efetuada a desapropriação, o órgão expropriante, dentro do prazo de 3 (três) anos, contados da data de registro do título translativo de domínio, destinará a respectiva área aos beneficiários da reforma agrária, admitindo-se, para tanto, formas de exploração individual, condominial, cooperativa, associativa ou mista.

Art. 17. O assentamento de trabalhadores rurais deverá ser efettrado em terras econemicamente úteis, de preferência na região por eles habitada.

Art. 17. O assentamento de trabalhadores rurais deverá ser realizado em terras economicamente úteis, de preferência na região por eles habitada, observado o seguinte: (Redação dada pela Medida Provisória $\mathrm{n}^{\circ}$ 2.183$\underline{56, \text { de 2001) }}$

I - a obtenção de terras rurais destinadas à implantação de projetos de assentamento integrantes do programa de reforma agrária será precedida de estudo sobre a viabilidade econômica e a potencialidade de uso dos recursos naturais; (Incluído pela Medida Provisória n ${ }^{\circ}$ 2.183-56, de 2001)

II - os beneficiários dos projetos de que trata o inciso I manifestarão sua concordância com as condições de obtenção das terras destinadas à implantação dos projetos de assentamento, inclusive quanto ao preço a ser pago pelo órgão federal executor do programa de reforma agrária e com relação aos recursos naturais; (Incluído pela Medida Provisória $\mathrm{n}^{\mathrm{0}} 2.183-56$, de 2001)

III - nos projetos criados será elaborado Plano de Desenvolvimento de Assentamento - PDA, que orientará a fixação de normas técnicas para a sua implantação e os respectivos investimentos; (Incluído pela Medida Provisória ${ }^{\circ} 2.183-56$, de 2001)

IV - integrarão a clientela de trabalhadores rurais para fins de assentamento em projetos de reforma agrária somente aqueles que satisfizerem os requisitos fixados para seleção e classificação, bem como as exigências contidas nos arts. 19, incisos I a V e seu parágrafo único, e 20 desta Lei; (Incluído pela Medida Provisória ${ }^{\circ}$ 2.183-56, de 2001)

V - a consolidação dos projetos de assentamento integrantes dos programas de reforma agrária dar-se-á com a concessão de créditos de instalação e a conclusão dos investimentos, bem como com a outorga do instrumento definitivo de titulação. (Incluído pela Medida Provisória nº 2.183-56, de 2001)

Parágrafo único. (Vetado.)

Art. 18. A distribuição de imóveis rurais pela reforma agrária far-se-á através de títulos de domínio ou de concessão de uso, inegociáveis pelo prazo de 10 (dez) anos.

Parágrafo único. O órgão federal competente manterá attalizado cadastro de áreas desapropriadas e de beneficiários da reforma agrária.

$\S 1^{\circ} \mathrm{O}$ título de domínio de que trata este artigo conterá cláusulas resolutivas e será outorgado ao beneficiário do programa de reforma agrária, de forma individual ou coletiva, após a realização dos serviços de medição e demarcação topográfica do imóvel a ser alienado. (Incluído pela Medida Provisória no 2.183-56, de $\underline{2001)}$

$\S 2^{\circ} \mathrm{Na}$ implantação do projeto de assentamento, será celebrado com o beneficiário do programa de reforma agrária contrato de concessão de uso, de forma individual ou coletiva, que conterá cláusulas resolutivas, estipulando-se os direitos e as obrigações da entidade concedente e dos concessionários, assegurando-se a estes o 
direito de adquirir, em definitivo, o título de domínio, nas condições previstas no $\S 1^{\circ}$, computado o período da concessão para fins da inegociabilidade de que trata este artigo. (Incluído pela Medida Provisória n 2.183-56, de 2001)

$\S 3^{\circ} \mathrm{O}$ valor da alienação do imóvel será definido por deliberação do Conselho Diretor do Instituto Nacional de Colonização e Reforma Agrária - INCRA, cujo ato fixará os critérios para a apuração do valor da parcela a ser cobrada do beneficiário do programa de reforma agrária. (Incluído pela Medida Provisória $\mathrm{n}^{\circ} 2.183$ $\underline{56, \text { de 2001) }}$

$\S 4^{\circ} \mathrm{O}$ valor do imóvel fixado na forma do $\S 3^{\circ}$ será pago em prestações anuais pelo beneficiário do programa de reforma agrária, amortizadas em até vinte anos, com carência de três anos e corrigidas monetariamente pela variação do IGP-DI. (Incluído pela Medida Provisória nº 2.183-56, de 2001)

$\S 5^{\circ}$ Será concedida ao beneficiário do programa de reforma agrária a redução de cinqüenta por cento da correção monetária incidente sobre a prestação anual, quando efetuado o pagamento até a data do vencimento da respectiva prestação. (Incluído pela Medida Provisória nº 2.183-56, de 2001)

$\S 6^{\circ}$ Os valores relativos às obras de infra-estrutura de interesse coletivo, aos custos despendidos com o plano de desenvolvimento do assentamento e aos serviços de medição e demarcação topográficos são considerados não reembolsáveis, sendo que os créditos concedidos aos beneficiários do programa de reforma agrária serão excluídos do valor das prestações e amortizados na forma a ser definida pelo órgão federal executor do programa. (Incluído pela Medida Provisória n ${ }^{\circ} 2.183-56$, de 2001)

$\S 7^{\circ} \mathrm{O}$ órgão federal executor do programa de reforma agrária manterá atualizado o cadastro de áreas desapropriadas e de beneficiários da reforma agrária. (Incluído pela Medida Provisória no 2.183-56, de 2001)

Art. 19. O título de domínio e a concessão de uso serão conferidos ao homem ou à mulher, ou a ambos, independentemente de estado civil, observada a seguinte ordem preferencial:

I - ao desapropriado, ficando-lhe assegurada a preferência para a parcela na qual se situe a sede do imóvel;

II - aos que trabalham no imóvel desapropriado como posseiros, assalariados, parceiros ou arrendatários;

III - aos ex-proprietários de terra cuja propriedade de área total compreendida entre um e quatro módulos fiscais tenha sido alienada para pagamento de débitos originados de operações de crédito rural ou perdida na condição de garantia de débitos da mesma origem; (Inciso incluído pela Lei no 10.279, de 12.9.2001)

IV - aos que trabalham como posseiros, assalariados, parceiros ou arrendatários, em outros imóveis; (Inciso renumerado pela Lei $\mathrm{n}^{\circ} 10.279$, de 12.9.2001)

V - aos agricultores cujas propriedades não alcancem a dimensão da propriedade familiar; (Inciso renumerado pela Lei ${ }^{\circ} 10.279$, de 12.9 .2001 )

VI - aos agricultores cujas propriedades sejam, comprovadamente, insuficientes para o sustento próprio e o de sua família. (Inciso renumerado pela Lei $\mathrm{n}^{\circ} 10.279$, de 12.9.2001)

Parágrafo único. Na ordem de preferência de que trata este artigo, terão prioridade os chefes de família numerosa, cujos membros se proponham a exercer a atividade agrícola na área a ser distribuída.

Art. 20. Não poderá ser beneficiário da distribuição de terras, a que se refere esta lei, o proprietário rural, salvo nos casos dos incisos I, IV e V do artigo anterior, nem o que exercer função pública, autárquica ou em órgão paraestatal, ou o que se ache investido de atribuição parafiscal, ou quem já tenha sido contemplado anteriormente com parcelas em programa de reforma agrária.

Art. 21. Nos instrumentos que conferem o título de domínio ou concessão de uso, os beneficiários da reforma agrária assumirão, obrigatoriamente, o compromisso de cultivar o imóvel direta e pessoalmente, ou através de seu núcleo familiar, mesmo que através de cooperativas, e o de não ceder o seu uso a terceiros, a qualquer título, pelo prazo de 10 (dez) anos.

Art. 22. Constará, obrigatoriamente, dos instrumentos translativos de domínio ou de concessão de uso cláusula resolutória que preveja a rescisão do contrato e o retorno do imóvel ao órgão alienante ou concedente, no caso de descumprimento de quaisquer das obrigações assumidas pelo adquirente ou concessionário.

Art. 23. O estrangeiro residente no País e a pessoa jurídica autorizada a funcionar no Brasil só poderão arrendar imóvel rural na forma da Lei nº 5.709, de 7 de outubro de 1971.

$\S 1^{\circ}$ Aplicam-se ao arrendamento todos os limites, restrições e condições aplicáveis à aquisição de imóveis rurais por estrangeiro, constantes da lei referida no caput deste artigo.

$\S 2^{\circ}$ Compete ao Congresso Nacional autorizar tanto a aquisição ou o arrendamento além dos limites de área e percentual fixados na Lei $\mathrm{n}^{\circ}$ 5.709, de 7 de outubro de 1971, como a aquisição ou arrendamento, por pessoa jurídica estrangeira, de área superior a 100 (cem) módulos de exploração indefinida.

Art. 24. As ações de reforma agrária devem ser compatíveis com as ações de política agrícola, e constantes no Plano Plurianual.

Art. 25. O orçamento da União fixará, anualmente, o volume de títulos da dívida agrária e dos recursos destinados, no exercício, ao atendimento do Programa de Reforma Agrária.

$\S 1^{\circ}$ Os recursos destinados à execução do Plano Nacional de Reforma Agrária deverão constar do orçamento do ministério responsável por sua implementação e do órgão executor da política de colonização e reforma agrária, salvo aqueles que, por sua natureza, exijam instituições especializadas para a sua aplicação. 
$\S 2^{\circ}$ Objetivando a compatibilização dos programas de trabalho e propostas orçamentárias, o órgão executor da reforma agrária encaminhará, anualmente e em tempo hábil, aos órgãos da administração pública responsáveis por ações complementares, o programa a ser implantado no ano subseqüente.

Art. 26. São isentas de impostos federais, estaduais e municipais, inclusive do Distrito Federal, as operações de transferência de imóveis desapropriados para fins de reforma agrária, bem como a transferência ao beneficiário do programa.

Art. 26-A. Não serão cobradas custas ou emolumentos para registro de títulos translativos de domínio de imóveis rurais desapropriados para fins de reforma agrária. (Incluído pela Medida Provisória $\mathrm{n}^{\circ}$ 2.183-56, de $\underline{2001)}$

Art. 27. Esta Lei entra em vigor na data de sua publicação.

Art. 28. Revogam-se as disposições em contrário.

Brasília, 25 de fevereiro de $1993,172^{\circ}$ da Independência e $105^{\circ}$ da República. ITAMAR FRANCO

Lázaro Ferreira Barbosa

Este texto não substitui o Publicado no DOU de 26.2.1993 
LEI No 10.257, DE 10 DE JULHO DE 2001.

Regula os arts. 182 e 183 da Constituição Federal, estabelece diretrizes gerais da política urbana e dá outras providências

O PRESIDENTE DA REPÚBLICA Faço saber que o Congresso Nacional decreta e eu sanciono a seguinte Lei:

CAPÍTULO I

DIRETRIZES GERAIS

Art. $1^{\circ} \mathrm{Na}$ execução da política urbana, de que tratam os arts. 182 e 183 da Constituição Federal, será aplicado o previsto nesta Lei.

Parágrafo único. Para todos os efeitos, esta Lei, denominada Estatuto da Cidade, estabelece normas de ordem pública e interesse social que regulam o uso da propriedade urbana em prol do bem coletivo, da segurança e do bem-estar dos cidadãos, bem como do equilíbrio ambiental.

Art. $2^{\circ}$ A política urbana tem por objetivo ordenar o pleno desenvolvimento das funções sociais da cidade e da propriedade urbana, mediante as seguintes diretrizes gerais:

I - garantia do direito a cidades sustentáveis, entendido como o direito à terra urbana, à moradia, ao saneamento ambiental, à infra-estrutura urbana, ao transporte e aos serviços públicos, ao trabalho e ao lazer, para as presentes e futuras gerações;

II - gestão democrática por meio da participação da população e de associações representativas dos vários segmentos da comunidade na formulação, execução e acompanhamento de planos, programas e projetos de desenvolvimento urbano;

III - cooperação entre os governos, a iniciativa privada e os demais setores da sociedade no processo de urbanização, em atendimento ao interesse social;

IV - planejamento do desenvolvimento das cidades, da distribuição espacial da população e das atividades econômicas do Município e do território sob sua área de influência, de modo a evitar e corrigir as distorções do crescimento urbano e seus efeitos negativos sobre o meio ambiente;

$\mathrm{V}$ - oferta de equipamentos urbanos e comunitários, transporte e serviços públicos adequados aos interesses e necessidades da população e às características locais;

VI - ordenação e controle do uso do solo, de forma a evitar:

a) a utilização inadequada dos imóveis urbanos;

b) a proximidade de usos incompatíveis ou inconvenientes;

c) o parcelamento do solo, a edificação ou o uso excessivos ou inadequados em relação à infra-estrutura urbana;

d) a instalação de empreendimentos ou atividades que possam funcionar como pólos geradores de tráfego, sem a previsão da infra-estrutura correspondente;

e) a retenção especulativa de imóvel urbano, que resulte na sua subutilização ou não utilização;

f) a deterioração das áreas urbanizadas;

g) a poluição e a degradação ambiental;

VII - integração e complementaridade entre as atividades urbanas e rurais, tendo em vista o desenvolvimento socioeconômico do Município e do território sob sua área de influência;

VIII - adoção de padrões de produção e consumo de bens e serviços e de expansão urbana compatíveis com os limites da sustentabilidade ambiental, social e econômica do Município e do território sob sua área de influência;

IX - justa distribuição dos benefícios e ônus decorrentes do processo de urbanização;

$\mathrm{X}$ - adequação dos instrumentos de política econômica, tributária e financeira e dos gastos públicos aos objetivos do desenvolvimento urbano, de modo a privilegiar os investimentos geradores de bem-estar geral e a fruição dos bens pelos diferentes segmentos sociais; urbanos;

XI - recuperação dos investimentos do Poder Público de que tenha resultado a valorização de imóveis

XII - proteção, preservação e recuperação do meio ambiente natural e construído, do patrimônio cultural, histórico, artístico, paisagístico e arqueológico;

XIII - audiência do Poder Público municipal e da população interessada nos processos de implantação de empreendimentos ou atividades com efeitos potencialmente negativos sobre o meio ambiente natural ou construído, o conforto ou a segurança da população;

XIV - regularização fundiária e urbanização de áreas ocupadas por população de baixa renda mediante o estabelecimento de normas especiais de urbanização, uso e ocupação do solo e edificação, consideradas a situação socioeconômica da população e as normas ambientais; 
XV - simplificação da legislação de parcelamento, uso e ocupação do solo e das normas edilícias, com vistas a permitir a redução dos custos e o aumento da oferta dos lotes e unidades habitacionais;

XVI - isonomia de condições para os agentes públicos e privados na promoção de empreendimentos e atividades relativos ao processo de urbanização, atendido o interesse social.

Art. $3^{\circ}$ Compete à União, entre outras atribuições de interesse da política urbana:

I - legislar sobre normas gerais de direito urbanístico;

II - legislar sobre normas para a cooperação entre a União, os Estados, o Distrito Federal e os Municípios em relação à política urbana, tendo em vista o equilíbrio do desenvolvimento e do bem-estar em âmbito nacional;

III - promover, por iniciativa própria e em conjunto com os Estados, o Distrito Federal e os Municípios, programas de construção de moradias e a melhoria das condições habitacionais e de saneamento básico;

IV - instituir diretrizes para o desenvolvimento urbano, inclusive habitação, saneamento básico e transportes urbanos;

$\mathrm{V}$ - elaborar e executar planos nacionais e regionais de ordenação do território e de desenvolvimento econômico e social.

\section{CAPÍTULO II}

\section{DOS INSTRUMENTOS DA POLÍTICA URBANA}

Seção I

Dos instrumentos em geral

Art. $4^{\circ}$ Para os fins desta Lei, serão utilizados, entre outros instrumentos: social;

I - planos nacionais, regionais e estaduais de ordenação do território e de desenvolvimento econômico e

II - planejamento das regiões metropolitanas, aglomerações urbanas e microrregiões;

III - planejamento municipal, em especial:

a) plano diretor;

b) disciplina do parcelamento, do uso e da ocupação do solo;

c) zoneamento ambiental;

d) plano plurianual;

e) diretrizes orçamentárias e orçamento anual;

f) gestão orçamentária participativa;

g) planos, programas e projetos setoriais;

h) planos de desenvolvimento econômico e social;

IV - institutos tributários e financeiros:

a) imposto sobre a propriedade predial e territorial urbana - IPTU;

b) contribuição de melhoria;

c) incentivos e benefícios fiscais e financeiros;

$\mathrm{V}$ - institutos jurídicos e políticos:

a) desapropriação;

b) servidão administrativa;

c) limitações administrativas;

d) tombamento de imóveis ou de mobiliário urbano;

e) instituição de unidades de conservação;

f) instituição de zonas especiais de interesse social;

g) concessão de direito real de uso;

h) concessão de uso especial para fins de moradia;

i) parcelamento, edificação ou utilização compulsórios;

j) usucapião especial de imóvel urbano;

1) direito de superfície;

m) direito de preempção;

n) outorga onerosa do direito de construir e de alteração de uso;

o) transferência do direito de construir;

p) operações urbanas consorciadas;

q) regularização fundiária;

r) assistência técnica e jurídica gratuita para as comunidades e grupos sociais menos favorecidos;

s) referendo popular e plebiscito;

VI - estudo prévio de impacto ambiental (EIA) e estudo prévio de impacto de vizinhança (EIV).

$\S 1^{\circ}$ Os instrumentos mencionados neste artigo regem-se pela legislação que lhes é própria, observado o disposto nesta Lei. 
$\S 2^{\circ}$ Nos casos de programas e projetos habitacionais de interesse social, desenvolvidos por órgãos ou entidades da Administração Pública com atuação específica nessa área, a concessão de direito real de uso de imóveis públicos poderá ser contratada coletivamente.

$\S 3^{\circ}$ Os instrumentos previstos neste artigo que demandam dispêndio de recursos por parte do Poder Público municipal devem ser objeto de controle social, garantida a participação de comunidades, movimentos e entidades da sociedade civil.

Seção II

Do parcelamento, edificação ou utilização compulsórios

Art. $5^{\circ}$ Lei municipal específica para área incluída no plano diretor poderá determinar o parcelamento, a edificação ou a utilização compulsórios do solo urbano não edificado, subutilizado ou não utilizado, devendo fixar as condições e os prazos para implementação da referida obrigação.

$\S 1^{\circ}$ Considera-se subutilizado o imóvel:

I - cujo aproveitamento seja inferior ao mínimo definido no plano diretor ou em legislação dele decorrente;

II - (VETADO)

$\S 2^{\circ} \mathrm{O}$ proprietário será notificado pelo Poder Executivo municipal para o cumprimento da obrigação, devendo a notificação ser averbada no cartório de registro de imóveis.

$\S 3^{\circ}$ A notificação far-se-á:

I - por funcionário do órgão competente do Poder Público municipal, ao proprietário do imóvel ou, no caso de este ser pessoa jurídica, a quem tenha poderes de gerência geral ou administração;

II - por edital quando frustrada, por três vezes, a tentativa de notificação na forma prevista pelo inciso I.

$\S 4^{\circ}$ Os prazos a que se refere o caput não poderão ser inferiores a:

I - um ano, a partir da notificação, para que seja protocolado o projeto no órgão municipal competente;

II - dois anos, a partir da aprovação do projeto, para iniciar as obras do empreendimento.

$\S 5^{\circ}$ Em empreendimentos de grande porte, em caráter excepcional, a lei municipal específica a que se refere o caput poderá prever a conclusão em etapas, assegurando-se que o projeto aprovado compreenda o empreendimento como um todo.

Art. $6^{\circ} \mathrm{A}$ transmissão do imóvel, por ato inter vivos ou causa mortis, posterior à data da notificação, transfere as obrigações de parcelamento, edificação ou utilização previstas no art. $5^{\circ}$ desta Lei, sem interrupção de quaisquer prazos.

Seção III

Do IPTU progressivo no tempo

Art. $7^{\circ} \mathrm{Em}$ caso de descumprimento das condições e dos prazos previstos na forma do caput do art. $5^{\circ}$ desta Lei, ou não sendo cumpridas as etapas previstas no $\S 5^{\circ}$ do art. $5^{\circ}$ desta Lei, o Município procederá à aplicação do imposto sobre a propriedade predial e territorial urbana (IPTU) progressivo no tempo, mediante a majoração da alíquota pelo prazo de cinco anos consecutivos.

$\S 1^{\circ} \mathrm{O}$ valor da alíquota a ser aplicado a cada ano será fixado na lei específica a que se refere o caput do art. $5^{\circ}$ desta Lei e não excederá a duas vezes o valor referente ao ano anterior, respeitada a alíquota máxima de quinze por cento.

$\S 2^{\circ}$ Caso a obrigação de parcelar, edificar ou utilizar não esteja atendida em cinco anos, o Município manterá a cobrança pela alíquota máxima, até que se cumpra a referida obrigação, garantida a prerrogativa prevista no art. $8^{\circ}$.

$\S 3^{\circ}$ É vedada a concessão de isenções ou de anistia relativas à tributação progressiva de que trata este artigo.

Seção IV

Da desapropriação com pagamento em títulos

Art. $8^{\circ}$ Decorridos cinco anos de cobrança do IPTU progressivo sem que o proprietário tenha cumprido a obrigação de parcelamento, edificação ou utilização, o Município poderá proceder à desapropriação do imóvel, com pagamento em títulos da dívida pública.

$\S 1^{\circ}$ Os títulos da dívida pública terão prévia aprovação pelo Senado Federal e serão resgatados no prazo de até dez anos, em prestações anuais, iguais e sucessivas, assegurados o valor real da indenização e os juros legais de seis por cento ao ano.

$\S 2^{\circ} \mathrm{O}$ valor real da indenização:

I - refletirá o valor da base de cálculo do IPTU, descontado o montante incorporado em função de obras realizadas pelo Poder Público na área onde o mesmo se localiza após a notificação de que trata o $\S 2^{\circ}$ do art. $5^{\circ}$ desta Lei;

II - não computará expectativas de ganhos, lucros cessantes e juros compensatórios.

$\S 3^{\circ}$ Os títulos de que trata este artigo não terão poder liberatório para pagamento de tributos.

$\S 4^{\circ}$ O Município procederá ao adequado aproveitamento do imóvel no prazo máximo de cinco anos, contado a partir da sua incorporação ao patrimônio público. 
$\S 5^{\circ} \mathrm{O}$ aproveitamento do imóvel poderá ser efetivado diretamente pelo Poder Público ou por meio de alienação ou concessão a terceiros, observando-se, nesses casos, o devido procedimento licitatório.

$\S 6^{\circ}$ Ficam mantidas para o adquirente de imóvel nos termos do $\S 5^{\circ}$ as mesmas obrigações de parcelamento, edificação ou utilização previstas no art. $5^{\circ}$ desta Lei.

Seção V

Da usucapião especial de imóvel urbano

Art. $9^{\circ}$ Aquele que possuir como sua área ou edificação urbana de até duzentos e cinqüenta metros quadrados, por cinco anos, ininterruptamente e sem oposição, utilizando-a para sua moradia ou de sua família, adquirir-lhe-á o domínio, desde que não seja proprietário de outro imóvel urbano ou rural.

$\S 1^{\circ} \mathrm{O}$ título de domínio será conferido ao homem ou à mulher, ou a ambos, independentemente do estado civil.

$\S 2^{\circ} \mathrm{O}$ direito de que trata este artigo não será reconhecido ao mesmo possuidor mais de uma vez.

$\S 3^{\circ}$ Para os efeitos deste artigo, o herdeiro legítimo continua, de pleno direito, a posse de seu antecessor, desde que já resida no imóvel por ocasião da abertura da sucessão.

Art. 10. As áreas urbanas com mais de duzentos e cinqüenta metros quadrados, ocupadas por população de baixa renda para sua moradia, por cinco anos, ininterruptamente e sem oposição, onde não for possível identificar os terrenos ocupados por cada possuidor, são susceptíveis de serem usucapidas coletivamente, desde que os possuidores não sejam proprietários de outro imóvel urbano ou rural.

$\S 1^{\circ} \mathrm{O}$ possuidor pode, para o fim de contar o prazo exigido por este artigo, acrescentar sua posse à de seu antecessor, contanto que ambas sejam contínuas.

$\S 2^{\circ}$ A usucapião especial coletiva de imóvel urbano será declarada pelo juiz, mediante sentença, a qual servirá de título para registro no cartório de registro de imóveis.

$\S 3^{\circ} \mathrm{Na}$ sentença, o juiz atribuirá igual fração ideal de terreno a cada possuidor, independentemente da dimensão do terreno que cada um ocupe, salvo hipótese de acordo escrito entre os condôminos, estabelecendo frações ideais diferenciadas.

$\S 4^{\circ} \mathrm{O}$ condomínio especial constituído é indivisível, não sendo passível de extinção, salvo deliberação favorável tomada por, no mínimo, dois terços dos condôminos, no caso de execução de urbanização posterior à constituição do condomínio.

$\S 5^{\circ}$ As deliberações relativas à administração do condomínio especial serão tomadas por maioria de votos dos condôminos presentes, obrigando também os demais, discordantes ou ausentes.

Art. 11. Na pendência da ação de usucapião especial urbana, ficarão sobrestadas quaisquer outras ações, petitórias ou possessórias, que venham a ser propostas relativamente ao imóvel usucapiendo.

Art. 12. São partes legítimas para a propositura da ação de usucapião especial urbana:

I - o possuidor, isoladamente ou em litisconsórcio originário ou superveniente;

II - os possuidores, em estado de composse;

III - como substituto processual, a associação de moradores da comunidade, regularmente constituída, com personalidade jurídica, desde que explicitamente autorizada pelos representados.

$\S 1^{\circ} \mathrm{Na}$ ação de usucapião especial urbana é obrigatória a intervenção do Ministério Público.

$\S 2^{\circ} \mathrm{O}$ autor terá os benefícios da justiça e da assistência judiciária gratuita, inclusive perante o cartório de registro de imóveis.

Art. 13. A usucapião especial de imóvel urbano poderá ser invocada como matéria de defesa, valendo a sentença que a reconhecer como título para registro no cartório de registro de imóveis. sumário.

Art. 14. Na ação judicial de usucapião especial de imóvel urbano, o rito processual a ser observado é o

Seção VI

Da concessão de uso especial para fins de moradia

Art. 15. (VETADO)

Art. 16. (VETADO)

Art. 17. (VETADO)

Art. 18. (VETADO)

Art. 19. (VETADO)

Art. 20. (VETADO)

Seção VII

Do direito de superfície

Art. 21. O proprietário urbano poderá conceder a outrem o direito de superfície do seu terreno, por tempo determinado ou indeterminado, mediante escritura pública registrada no cartório de registro de imóveis.

$\S 1^{\circ} \mathrm{O}$ direito de superfície abrange o direito de utilizar o solo, o subsolo ou o espaço aéreo relativo ao terreno, na forma estabelecida no contrato respectivo, atendida a legislação urbanística.

$\S 2^{\circ}$ A concessão do direito de superfície poderá ser gratuita ou onerosa. 
$\S 3^{\circ} \mathrm{O}$ superficiário responderá integralmente pelos encargos e tributos que incidirem sobre a propriedade superficiária, arcando, ainda, proporcionalmente à sua parcela de ocupação efetiva, com os encargos e tributos sobre a área objeto da concessão do direito de superfície, salvo disposição em contrário do contrato respectivo.

$\S 4^{\circ} \mathrm{O}$ direito de superfície pode ser transferido a terceiros, obedecidos os termos do contrato respectivo.

$\S 5^{\circ}$ Por morte do superficiário, os seus direitos transmitem-se a seus herdeiros.

Art. 22. Em caso de alienação do terreno, ou do direito de superfície, o superficiário e o proprietário, respectivamente, terão direito de preferência, em igualdade de condições à oferta de terceiros.

Art. 23. Extingue-se o direito de superfície:

I - pelo advento do termo;

II - pelo descumprimento das obrigações contratuais assumidas pelo superficiário.

Art. 24. Extinto o direito de superfície, o proprietário recuperará o pleno domínio do terreno, bem como das acessões e benfeitorias introduzidas no imóvel, independentemente de indenização, se as partes não houverem estipulado o contrário no respectivo contrato.

$\S 1^{\circ}$ Antes do termo final do contrato, extinguir-se-á o direito de superfície se o superficiário der ao terreno destinação diversa daquela para a qual for concedida.

$\S 2^{\circ}$ A extinção do direito de superfície será averbada no cartório de registro de imóveis.

Seção VIII

Do direito de preempção

Art. 25. O direito de preempção confere ao Poder Público municipal preferência para aquisição de imóvel urbano objeto de alienação onerosa entre particulares.

$\S 1^{\circ}$ Lei municipal, baseada no plano diretor, delimitará as áreas em que incidirá o direito de preempção e fixará prazo de vigência, não superior a cinco anos, renovável a partir de um ano após o decurso do prazo inicial de vigência.

$\S 2^{\circ} \mathrm{O}$ direito de preempção fica assegurado durante o prazo de vigência fixado na forma do $\S 1^{\circ}$, independentemente do número de alienações referentes ao mesmo imóvel.

Art. 26. O direito de preempção será exercido sempre que o Poder Público necessitar de áreas para:

I - regularização fundiária;

II - execução de programas e projetos habitacionais de interesse social;

III - constituição de reserva fundiária;

IV - ordenamento e direcionamento da expansão urbana;

V - implantação de equipamentos urbanos e comunitários;

VI - criação de espaços públicos de lazer e áreas verdes;

VII - criação de unidades de conservação ou proteção de outras áreas de interesse ambiental;

VIII - proteção de áreas de interesse histórico, cultural ou paisagístico;

$\mathrm{IX}-(\mathrm{VETADO})$

Parágrafo único. A lei municipal prevista no $\S 1^{\circ}$ do art. 25 desta Lei deverá enquadrar cada área em que incidirá o direito de preempção em uma ou mais das finalidades enumeradas por este artigo.

Art. 27. O proprietário deverá notificar sua intenção de alienar o imóvel, para que o Município, no prazo máximo de trinta dias, manifeste por escrito seu interesse em comprá-lo.

$\S 1^{\circ}$ À notificação mencionada no caput será anexada proposta de compra assinada por terceiro interessado na aquisição do imóvel, da qual constarão preço, condições de pagamento e prazo de validade.

$\S 2^{\circ} \mathrm{O}$ Município fará publicar, em órgão oficial e em pelo menos um jornal local ou regional de grande circulação, edital de aviso da notificação recebida nos termos do caput e da intenção de aquisição do imóvel nas condições da proposta apresentada.

$\S 3^{\circ}$ Transcorrido o prazo mencionado no caput sem manifestação, fica o proprietário autorizado a realizar a alienação para terceiros, nas condições da proposta apresentada.

$\S 4^{\circ}$ Concretizada a venda a terceiro, o proprietário fica obrigado a apresentar ao Município, no prazo de trinta dias, cópia do instrumento público de alienação do imóvel.

$\S 5^{\circ} \mathrm{A}$ alienação processada em condições diversas da proposta apresentada é nula de pleno direito.

$\S 6^{\circ}$ Ocorrida a hipótese prevista no $\S 5^{\circ}$ o Município poderá adquirir o imóvel pelo valor da base de cálculo do IPTU ou pelo valor indicado na proposta apresentada, se este for inferior àquele.

Seção IX

Da outorga onerosa do direito de construir

Art. 28. O plano diretor poderá fixar áreas nas quais o direito de construir poderá ser exercido acima do coeficiente de aproveitamento básico adotado, mediante contrapartida a ser prestada pelo beneficiário.

$\S 1^{\circ}$ Para os efeitos desta Lei, coeficiente de aproveitamento é a relação entre a área edificável e a área do terreno.

$\S 2^{\circ} \mathrm{O}$ plano diretor poderá fixar coeficiente de aproveitamento básico único para toda a zona urbana ou diferenciado para áreas específicas dentro da zona urbana. 
$\S 3^{\circ} \mathrm{O}$ plano diretor definirá os limites máximos a serem atingidos pelos coeficientes de aproveitamento, considerando a proporcionalidade entre a infra-estrutura existente e o aumento de densidade esperado em cada área.

Art. 29. O plano diretor poderá fixar áreas nas quais poderá ser permitida alteração de uso do solo, mediante contrapartida a ser prestada pelo beneficiário.

Art. 30. Lei municipal específica estabelecerá as condições a serem observadas para a outorga onerosa do direito de construir e de alteração de uso, determinando:

I - a fórmula de cálculo para a cobrança;

II - os casos passíveis de isenção do pagamento da outorga;

III - a contrapartida do beneficiário.

Art. 31. Os recursos auferidos com a adoção da outorga onerosa do direito de construir e de alteração de uso serão aplicados com as finalidades previstas nos incisos I a IX do art. 26 desta Lei.

Seção X

Das operações urbanas consorciadas

Art. 32. Lei municipal específica, baseada no plano diretor, poderá delimitar área para aplicação de operações consorciadas.

$\S 1^{\circ}$ Considera-se operação urbana consorciada o conjunto de intervenções e medidas coordenadas pelo Poder Público municipal, com a participação dos proprietários, moradores, usuários permanentes e investidores privados, com o objetivo de alcançar em uma área transformações urbanísticas estruturais, melhorias sociais e a valorização ambiental.

$\S 2^{\circ}$ Poderão ser previstas nas operações urbanas consorciadas, entre outras medidas:

I - a modificação de índices e características de parcelamento, uso e ocupação do solo e subsolo, bem como alterações das normas edilícias, considerado o impacto ambiental delas decorrente;

II - a regularização de construções, reformas ou ampliações executadas em desacordo com a legislação vigente.

Art. 33. Da lei específica que aprovar a operação urbana consorciada constará o plano de operação urbana consorciada, contendo, no mínimo:

I - definição da área a ser atingida;

II - programa básico de ocupação da área;

III - programa de atendimento econômico e social para a população diretamente afetada pela operação;

IV - finalidades da operação;

$\mathrm{V}$ - estudo prévio de impacto de vizinhança;

VI - contrapartida a ser exigida dos proprietários, usuários permanentes e investidores privados em função da utilização dos benefícios previstos nos incisos I e II do $\S 2^{\circ}$ do art. 32 desta Lei;

VII - forma de controle da operação, obrigatoriamente compartilhado com representação da sociedade civil.

$\S 1^{\circ}$ Os recursos obtidos pelo Poder Público municipal na forma do inciso VI deste artigo serão aplicados exclusivamente na própria operação urbana consorciada.

$\S 2^{\circ}$ A partir da aprovação da lei específica de que trata o caput, são nulas as licenças e autorizações a cargo do Poder Público municipal expedidas em desacordo com o plano de operação urbana consorciada.

Art. 34. A lei específica que aprovar a operação urbana consorciada poderá prever a emissão pelo Município de quantidade determinada de certificados de potencial adicional de construção, que serão alienados em leilão ou utilizados diretamente no pagamento das obras necessárias à própria operação.

$\S 1^{\circ}$ Os certificados de potencial adicional de construção serão livremente negociados, mas conversíveis em direito de construir unicamente na área objeto da operação.

$\S 2^{\circ}$ Apresentado pedido de licença para construir, o certificado de potencial adicional será utilizado no pagamento da área de construção que supere os padrões estabelecidos pela legislação de uso e ocupação do solo, até o limite fixado pela lei específica que aprovar a operação urbana consorciada.

Seção XI

Da transferência do direito de construir

Art. 35. Lei municipal, baseada no plano diretor, poderá autorizar o proprietário de imóvel urbano, privado ou público, a exercer em outro local, ou alienar, mediante escritura pública, o direito de construir previsto no plano diretor ou em legislação urbanística dele decorrente, quando o referido imóvel for considerado necessário para fins de:

I - implantação de equipamentos urbanos e comunitários; cultural;

II - preservação, quando o imóvel for considerado de interesse histórico, ambiental, paisagístico, social ou

III - servir a programas de regularização fundiária, urbanização de áreas ocupadas por população de baixa renda e habitação de interesse social. 
$\S 1^{\circ}$ A mesma faculdade poderá ser concedida ao proprietário que doar ao Poder Público seu imóvel, ou parte dele, para os fins previstos nos incisos I a III do caput.

$\S 2^{\circ}$ A lei municipal referida no caput estabelecerá as condições relativas à aplicação da transferência do direito de construir.

Seção XII

Do estudo de impacto de vizinhança

Art. 36. Lei municipal definirá os empreendimentos e atividades privados ou públicos em área urbana que dependerão de elaboração de estudo prévio de impacto de vizinhança (EIV) para obter as licenças ou autorizações de construção, ampliação ou funcionamento a cargo do Poder Público municipal.

Art. 37. O EIV será executado de forma a contemplar os efeitos positivos e negativos do empreendimento ou atividade quanto à qualidade de vida da população residente na área e suas proximidades, incluindo a análise, no mínimo, das seguintes questões:

I - adensamento populacional;

II - equipamentos urbanos e comunitários;

III - uso e ocupação do solo;

IV - valorização imobiliária;

V - geração de tráfego e demanda por transporte público;

VI - ventilação e iluminação;

VII - paisagem urbana e patrimônio natural e cultural.

Parágrafo único. Dar-se-á publicidade aos documentos integrantes do EIV, que ficarão disponíveis para consulta, no órgão competente do Poder Público municipal, por qualquer interessado.

Art. 38. A elaboração do EIV não substitui a elaboração e a aprovação de estudo prévio de impacto ambiental (EIA), requeridas nos termos da legislação ambiental.

CAPÍTULO III

DO PLANO DIRETOR

Art. 39. A propriedade urbana cumpre sua função social quando atende às exigências fundamentais de ordenação da cidade expressas no plano diretor, assegurando o atendimento das necessidades dos cidadãos quanto à qualidade de vida, à justiça social e ao desenvolvimento das atividades econômicas, respeitadas as diretrizes previstas no art. $2^{\circ}$ desta Lei.

Art. 40. O plano diretor, aprovado por lei municipal, é o instrumento básico da política de desenvolvimento e expansão urbana.

$\S 1^{\circ} \mathrm{O}$ plano diretor é parte integrante do processo de planejamento municipal, devendo o plano plurianual, as diretrizes orçamentárias e o orçamento anual incorporar as diretrizes e as prioridades nele contidas.

$\S 2^{\circ} \mathrm{O}$ plano diretor deverá englobar o território do Município como um todo.

$\S 3^{\circ} \mathrm{A}$ lei que instituir o plano diretor deverá ser revista, pelo menos, a cada dez anos.

$\S 4^{\circ}$ No processo de elaboração do plano diretor e na fiscalização de sua implementação, os Poderes Legislativo e Executivo municipais garantirão:

I - a promoção de audiências públicas e debates com a participação da população e de associações representativas dos vários segmentos da comunidade;

II - a publicidade quanto aos documentos e informações produzidos;

III - o acesso de qualquer interessado aos documentos e informações produzidos.

$\S 5^{\circ}$ (VETADO)

Art. 41 . O plano diretor é obrigatório para cidades:

I - com mais de vinte mil habitantes;

II - integrantes de regiões metropolitanas e aglomerações urbanas;

III - onde o Poder Público municipal pretenda utilizar os instrumentos previstos no $\S 4^{\circ}$ do art. 182 da Constituição Federal;

IV - integrantes de áreas de especial interesse turístico;

$\mathrm{V}$ - inseridas na área de influência de empreendimentos ou atividades com significativo impacto ambiental de âmbito regional ou nacional.

$\S 1^{\circ}$ No caso da realização de empreendimentos ou atividades enquadrados no inciso $\mathrm{V}$ do caput, os recursos técnicos e financeiros para a elaboração do plano diretor estarão inseridos entre as medidas de compensação adotadas.

$\S 2^{\circ}$ No caso de cidades com mais de quinhentos mil habitantes, deverá ser elaborado um plano de transporte urbano integrado, compatível com o plano diretor ou nele inserido.

Art. 42. O plano diretor deverá conter no mínimo:

I - a delimitação das áreas urbanas onde poderá ser aplicado o parcelamento, edificação ou utilização compulsórios, considerando a existência de infra-estrutura e de demanda para utilização, na forma do art. $5^{\circ}$ desta Lei;

II - disposições requeridas pelos arts. 25, 28, 29, 32 e 35 desta Lei; 
III - sistema de acompanhamento e controle.

CAPÍTULO IV

DA GESTÃO DEMOCRÁTICA DA CIDADE

Art. 43. Para garantir a gestão democrática da cidade, deverão ser utilizados, entre outros, os seguintes instrumentos:

I - órgãos colegiados de política urbana, nos níveis nacional, estadual e municipal;

II - debates, audiências e consultas públicas;

III - conferências sobre assuntos de interesse urbano, nos níveis nacional, estadual e municipal;

IV - iniciativa popular de projeto de lei e de planos, programas e projetos de desenvolvimento urbano;

$\mathrm{V}-\underline{\text { (VETADO) }}$

Art. 44. No âmbito municipal, a gestão orçamentária participativa de que trata a alínea f do inciso III do art. $4^{\circ}$ desta Lei incluirá a realização de debates, audiências e consultas públicas sobre as propostas do plano plurianual, da lei de diretrizes orçamentárias e do orçamento anual, como condição obrigatória para sua aprovação pela Câmara Municipal.

Art. 45. Os organismos gestores das regiões metropolitanas e aglomerações urbanas incluirão obrigatória e significativa participação da população e de associações representativas dos vários segmentos da comunidade, de modo a garantir o controle direto de suas atividades e o pleno exercício da cidadania.

CAPÍTULO V

DISPOSIÇÕES GERAIS

Art. 46. O Poder Público municipal poderá facultar ao proprietário de área atingida pela obrigação de que trata o caput do art. $5^{\circ}$ desta Lei, a requerimento deste, o estabelecimento de consórcio imobiliário como forma de viabilização financeira do aproveitamento do imóvel.

$\S 1^{\circ}$ Considera-se consórcio imobiliário a forma de viabilização de planos de urbanização ou edificação por meio da qual o proprietário transfere ao Poder Público municipal seu imóvel e, após a realização das obras, recebe, como pagamento, unidades imobiliárias devidamente urbanizadas ou edificadas.

$\S 2^{\circ} \mathrm{O}$ valor das unidades imobiliárias a serem entregues ao proprietário será correspondente ao valor do imóvel antes da execução das obras, observado o disposto no $\S 2^{\circ}$ do art. $8^{\circ}$ desta Lei.

Art. 47. Os tributos sobre imóveis urbanos, assim como as tarifas relativas a serviços públicos urbanos, serão diferenciados em função do interesse social.

Art. 48. Nos casos de programas e projetos habitacionais de interesse social, desenvolvidos por órgãos ou entidades da Administração Pública com atuação específica nessa área, os contratos de concessão de direito real de uso de imóveis públicos:

I - terão, para todos os fins de direito, caráter de escritura pública, não se aplicando o disposto no inciso II do art. 134 do Código Civil;

II - constituirão título de aceitação obrigatória em garantia de contratos de financiamentos habitacionais.

Art. 49. Os Estados e Municípios terão o prazo de noventa dias, a partir da entrada em vigor desta Lei, para fixar prazos, por lei, para a expedição de diretrizes de empreendimentos urbanísticos, aprovação de projetos de parcelamento e de edificação, realização de vistorias e expedição de termo de verificação e conclusão de obras.

Parágrafo único. Não sendo cumprida a determinação do caput, fica estabelecido o prazo de sessenta dias para a realização de cada um dos referidos atos administrativos, que valerá até que os Estados e Municípios disponham em lei de forma diversa.

Art. 50. Os Municípios que estejam enquadrados na obrigação prevista nos incisos I e II do art. 41 desta Lei que não tenham plano diretor aprovado na data de entrada em vigor desta Lei, deverão aprová-lo no prazo de cinco anos.

Art. 51. Para os efeitos desta Lei, aplicam-se ao Distrito Federal e ao Governador do Distrito Federal as disposições relativas, respectivamente, a Município e a Prefeito.

Art. 52. Sem prejuízo da punição de outros agentes públicos envolvidos e da aplicação de outras sanções cabíveis, o Prefeito incorre em improbidade administrativa, nos termos da Lei $\mathrm{n}^{\circ}$ 8.429, de 2 de junho de 1992 , quando:

$\mathrm{I}-\underline{(\mathrm{VETADO})}$

II - deixar de proceder, no prazo de cinco anos, o adequado aproveitamento do imóvel incorporado ao patrimônio público, conforme o disposto no $\S 4^{\circ}$ do art. $8^{\circ}$ desta Lei; Lei;

III - utilizar áreas obtidas por meio do direito de preempção em desacordo com o disposto no art. 26 desta

IV - aplicar os recursos auferidos com a outorga onerosa do direito de construir e de alteração de uso em desacordo com o previsto no art. 31 desta Lei;

$\mathrm{V}$ - aplicar os recursos auferidos com operações consorciadas em desacordo com o previsto no $\S 1^{\circ}$ do art. 33 desta Lei;

VI - impedir ou deixar de garantir os requisitos contidos nos incisos I a III do $\S 4^{\circ}$ do art. 40 desta Lei; 
VII - deixar de tomar as providências necessárias para garantir a observância do disposto no $\S 3^{\circ}$ do art. 40 e no art. 50 desta Lei;

VIII - adquirir imóvel objeto de direito de preempção, nos termos dos arts. 25 a 27 desta Lei, pelo valor da proposta apresentada, se este for, comprovadamente, superior ao de mercado.

Art. 53. $O$ art. $1^{\ominus}$ da Lei $\mathrm{n}^{\ominus} 7.347$, de 24 de jutho de 1985 , passa a vigorar acrescido de novo inciso III, renumerando o attal inciso II es subseqüientes: .(Revogado pela Medida Provisória $\mathrm{n}^{\circ}$ 2.180-35, de 24.8.2001) "Art. $1^{\ominus}$

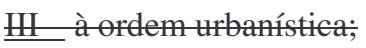

Art. 54. O art. $4^{\circ}$ da Lei $\mathrm{n}^{\circ} 7.347$, de 1985 , passa a vigorar com a seguinte redação:

"Art. $4^{\circ}$ Poderá ser ajuizada ação cautelar para os fins desta Lei, objetivando, inclusive, evitar o dano ao meio ambiente, ao consumidor, à ordem urbanística ou aos bens e direitos de valor artístico, estético, histórico, turístico e paisagístico (VETADO)." (NR)

Art. 55. O art. 167, inciso I, item 28, da Lei $\mathrm{n}^{\circ}$ 6.015, de 31 de dezembro de 1973, alterado pela Lei $\mathrm{n}^{\circ}$ 6.216, de 30 de junho de 1975, passa a vigorar com a seguinte redação:

"Art. 167.

I -

28) das sentenças declaratórias de usucapião, independente da regularidade do parcelamento do solo ou da edificação;

Art. 56. O art. 167, inciso I, da Lei $\mathrm{n}^{\circ}$ 6.015, de 1973, passa a vigorar acrescido dos seguintes itens 37,38 e 39:

"Art. 167.

I -

$\underline{37)}$ dos termos administrativos ou das sentenças declaratórias da concessão de uso especial para fins de moradia, independente da regularidade do parcelamento do solo ou da edificação;

38) (VETADO)

39) da constituição do direito de superfície de imóvel urbano;" (NR) e 20:

Art. 57. O art. 167, inciso II, da Lei $\mathrm{n}^{0}$ 6.015, de 1973, passa a vigorar acrescido dos seguintes itens 18,19

"Art. 167.

II - ....

18) da notificação para parcelamento, edificação ou utilização compulsórios de imóvel urbano;

$\underline{19)}$ da extinção da concessão de uso especial para fins de moradia;

$\underline{20)}$ da extinção do direito de superfície do imóvel urbano." (NR)

Art. 58. Esta Lei entra em vigor após decorridos noventa dias de sua publicação.

Brasília, 10 de julho de 2001; $180^{\circ}$ da Independência e $113^{\circ}$ da República.

FERNANDO HENRIQUE CARDOSO

Paulo de Tarso Ramos Ribeiro

Geraldo Magela da Cruz Quintão

Pedro Malan

Benjamin Benzaquen Sicsú

Martus Tavares

José Sarney Filho

Alberto Mendes Cardoso

Este texto não substitui o publicado no D.O.U. de 11.7.2001 